\title{
2011
}

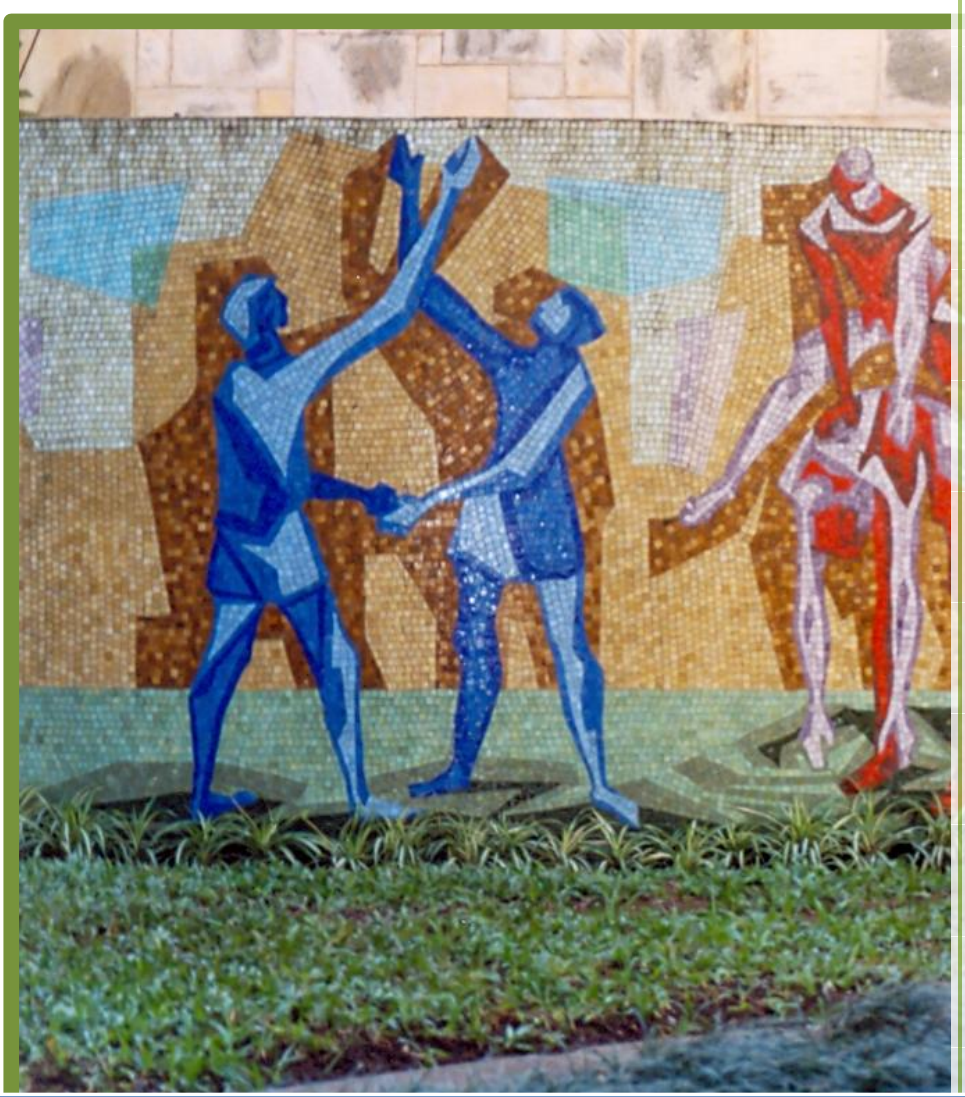

\section{A ARTE MURAL E A PRÁTICA DA PRESERVAÇÃO}

UNIVERSIDADE DE SÃO PAULO FACULDADE DE ARQUITETURA E URBANISMO Vera Regina Barbuy Wilhelm SÃO PAULO 
VERA REGINA BARBUY WILHELM

\author{
A ARTE MURAL
}

E

\title{
A PRÁTICA DA PRESERVAÇÃO
}

Tese apresentada à Faculdade de Arquitetura

e Urbanismo da Universidade de São Paulo, para obtenção do título de Doutor em Arquitetura e Urbanismo

Área de Concentração: História e Fundamentos da Arquitetura e do Urbanismo

Orientador: Prof. Dr. Luciano Migliaccio

Exemplar revisado e alterado em relação à versão original, sob responsabilidade do autor e anuência do orientador. O original se encontra disponível na sede do programa.

São Paulo, 21 de outubro de 2011. 
AUTORIZO A REPRODUÇÃO E DIVULGAÇÃO TOTAL OU PARCIAL DESTE TRABALHO, POR QUALQUER MEIO CONVENCIONAL OU ELETRÔNICO, PARA FINS DE ESTUDO E PESQUISA, DESDE QUE CITADA A FONTE.

E-MAIL: vera wilhelm@hotmail.com

Wilhelm, Vera Regina Barbuy

W678p A arte mural e a prática da preservação / Vera Regina Barbuy Wilhelm. - São Paulo, 2011.

254 p. : il.

Tese (Doutorado - Área de Concentração: História e Fundamentos da Arquitetura e do Urbanismo) - FAUUSP.

Orientador: Luciano Migliaccio

1.Murais - Conservação - Restauração - São Paulo(SP)

I.Título

CDU $75.052(816.11)$ 


\section{DEDICATÓRIA}

À minha mãe, com toda a minha admiração e gratidão pelo amor dedicado aos filhos, pela presença constante e pelo apoio. 


\section{AGRADECIMENTOS}

Ao meu orientador por transmitir tanta tranqüilidade e compreensão.

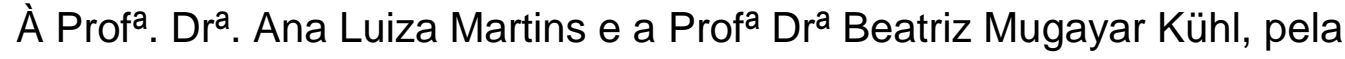
colaboração com palavras de incentivo e apoio no exame de qualificação. À amiga Marisa, pelas conversas e trocas de idéias. À Renata e a Silvia pelo constante incentivo. Aos funcionários do DPH.

Ao setor de Documentação do Condephaat.

Aos colegas que colaboraram com o preenchimento do questionário. Às funcionárias da Secretaria e da Biblioteca FAU USP e FAU Maranhão. A todos que de forma direta e indireta colaboraram para a execução deste trabalho. 
As grandes obras de arte somente são grandes por serem acessíveis e compreendidas por todos.

(Tolstoi) 


\section{RESUMO}

Este trabalho de pesquisa é sobre a prática da preservação da arte mural, desenvolvida na cidade de São Paulo e tem como objetivo identificar as bases do pensamento preservacionista da arte mural através da análise das intervenções de profissionais atuantes na área de conservação e restauração de obras murais, que se encontram remanescentes na arquitetura paulistana.

O recorte escolhido para objeto de estudo corresponde aos trabalhos de arte mural realizados no período entre 1930 e 1960, período no qual houve uma intensa produção dessa arte na cidade de São Paulo, por artistas que estiveram vinculados ao Grupo Santa Helena. Foi considerado, também, o período correspondente ao final do século $X X$ e início do século $X X I$ como sendo o marco das intervenções nas obras murais que coincidem com o crescimento e incentivo das atividades de conservação e restauração e da preservação da arquitetura moderna.

Através desta reflexão são considerados os conceitos que orientam a preservação da arte mural do ponto de vista teórico e a sua implantação na prática da conservação e restauração. A partir das intervenções de restauro sofridas pelas obras buscou-se desenvolver uma análise e também reunir elementos que permitissem criar subsídios para diretrizes de conservação e para estabelecimento de uma futura política de preservação integrada e preventiva das obras de arte mural, que fossem adequadas à nossa realidade.

Palavras chaves: Arte Mural, Preservação, Conservação-Restauração, Bens Integrados. 


\section{ABSTRACT}

This research is related to the practice of preservation of mural art developed in the city of São Paulo and the objective of this study is to identify the foundations of mural art preservation thought, through the professionals interventions works in the field of conservation and restoration of mural art, which are remains in architecture of São Paulo city.

The cut-off chosen for this study corresponds to works of mural art made in the period between 1930 and 1960, during which there was an intense production of this type of art in São Paulo city, by artists who were linked to the Grupo Santa Helena. It was considered also the period corresponding to the late 20th and early 21 st century, as an important period of the interventions in mural artworks that coincide with growth and encouraging the activities of conservation and restoration and the preservation of modern architecture.

Through this reflection are considered the concepts that guide the preservation of this art from the theoretical point of view and its implementation in practice of conservation and restoration. From the restoration intervention experienced by artworks the research has involved the search for development of an analysis and also gather elements which allows creating subsidies to conservation guidelines and to establish a future policy of integrated and preventive preservation of mural artworks, which were suitable for our reality.

KEY WORDS: Mural Art, Preservation, Conservation-Restoration, Integrated Art. 


\section{LISTA DE ILUSTRAÇÕES}

Figura 1 Ministério da Educação e Saúde. 42

$\begin{array}{lll}\text { Figura } 2 \text { Detalhe do mural de azulejo. } & 42\end{array}$

$\begin{array}{lll}\text { Figura } 3 & \text { Algumas Cartas Patrimoniais Nacionais. } & 54\end{array}$

Figura $4 \quad$ Elementos componentes das práticas de atuação. 96

$\begin{array}{lll}\text { Figura } 5 & \text { Esquema das atividades práticas de conservação e } & 97\end{array}$ restauração.

$\begin{array}{lll}\text { Figura } 6 & \text { Remoção da obra de Pennacchi. } & 104\end{array}$

$\begin{array}{lll}\text { Figura } 7 & \text { Remoção da obra de Pennacchi. } & 104\end{array}$

$\begin{array}{lll}\text { Figura } 8 & \text { Artista com sua obra reinstalada em novo local. } & 104\end{array}$

$\begin{array}{lll}\text { Figura } 9 & \text { Colocação de obra em novo local. } & 104\end{array}$

$\begin{array}{lll}\text { Figura } 10 \text { Colocação de obra em novo local. } & 104\end{array}$

Figura 11 Mural exposto na parede dos fundos da loja Lopan. 105

$\begin{array}{lll}\text { Figura } 12 & \text { Mural Cavalgada Medieval. } & 106\end{array}$

$\begin{array}{lll}\text { Figura } 13 & \text { Painel de gesso recobrindo o mural. } & 106\end{array}$

$\begin{array}{lll}\text { Figura } 14 & \text { Painel de gesso recobrindo o mural. } & 107\end{array}$

$\begin{array}{lll}\text { Figura } 15 & \text { Detalhe do painel de gesso. } & 107\end{array}$

$\begin{array}{lll}\text { Figura } 16 & \text { Painel de gesso removido. } & 107\end{array}$

$\begin{array}{lll}\text { Figura } 17 & \text { Detalhe do mural. } & 107\end{array}$

$\begin{array}{lll}\text { Figura } 18 \text { Detalhe da assinatura. } & 107\end{array}$

$\begin{array}{lll}\text { Figura } 19 & \text { Detalhe do Mural. } & 107\end{array}$

Figura $20 \quad$ Mural “Ceia dos Emaús” 1956.

$\begin{array}{lll}\text { Figura } 21 \text { Tombamento de fachada. } & 110\end{array}$

$\begin{array}{lll}\text { Figura } 22 & \text { Proteção de vidro no mural interno. } & 110\end{array}$ 
Figura 23 Proteção de vidro no mural externo.

Figura 24 Teatro João Caetano.

Figura 25 Teatro Arthur de Azevedo.

Figura 26 Teatro Paulo Eiró.

Figura 27 Le Corbusier, Projeto para o Palácio dos Soviets. Maquete, vista do conjunto. Moscou. 1931.

Figura 28 Teatro João Caetano

Figura 29 Localização do Teatro João Caetano vista aérea.

Figura 30 Saguão de entrada

Figura 31 Mural "Alegoria às Artes"

Figura 32 Carta da PMSP- Comissão do Convênio Escolar para Clovis 120 Graciano

Figura 33 Placa comemorativa de inauguração do Teatro.

Figura 34 Saguão de entrada.

Figura 35 Saguão de entrada.

Figura 36 Saguão de entrada.

Figura 37 Mural "Alegoria às Artes".

Figura $38 \quad$ Placa indicativa da reforma executada.

Figura 39 Placa indicativa da reforma executada 1999.

Figura 40 Área com registro da autoria da intervenção.

Figura 41 Detalhe do registro e data da autoria da intervenção.

Figura 42 Área repintada e teste de remoção.

Figura 43 Área repintada e teste de remoção.

Figura 44 Detalhes das áreas de perda.

Figura 45 Detalhes das áreas de perda. 
Figura 46 Detalhe da remoção da área de repintura.

Figura 47 Detalhe da remoção da área de repintura.

Figura 48 Localização do Edifício Bienal - Vila Nova Conceição.

Figura 49 Vista de Edifício Bienal 1955.

Figura 50 Vista lateral do Edifício Bienal.

Figura 51 Fachada da Rua São Lourenço 1955.

Figura 52 Planta do pavimento térreo apartamento e loja.

Figura 53 Planta do $1^{\circ}$ pavimento apartamento e escritório.

Figura 54 Vista do mural na fachada da Rua João Lourenço.

Figura 55 Área destina ao mural na fachada da Rua João Lourenço.

Figura 56 Mural na Rua João Lourenço.

Figura 57 Mural na Rua João Lourenço.

Figura 58 Edifício Bienal.

Figura 59 Edifício Bienal.

Figura 60 Edifício Bienal Obra de Clovis Graciano Pichada entre 2003 /2004.

Figura 61 Edifício Bienal Detalhe da área de perda.

Figura 62 Edifício Bienal Detalhe da área de assinatura.

Figura 63 Intervenção de repintura realizada em dez. 2007.

Figura 64 Detalhes das áreas repintadas.

Figura 65 Detalhes das áreas repintadas.

Figura 66 Áreas repintadas e com rejunte diferenciado.

Figura 67 Áreas repintadas e com rejunte diferenciado.

Figura 68 Detalhe da intervenção no mural.

Figura 69 Placa da empresa que executou a recuperação da fachada no Edifício Bienal 
Figura 70 Vista da proteção de vidro colocada no mural

$\begin{array}{lll}\text { Figura } 71 \text { Vista da proteção de vidro colocada no mural } & 140\end{array}$

Figura 72 Vista da proteção de vidro colocada no mural 140

$\begin{array}{lll}\text { Figura } 73 \text { Detalhes da repintura no mural. } & 140\end{array}$

$\begin{array}{lll}\text { Figura } 74 & \text { Vista da proteção de vidro colocada no mural. } & 140\end{array}$

Figura 75 Detalhes da repintura, iluminação e proteção do mural. 141

Figura 76 Detalhes da repintura, iluminação e proteção do mural. 141

Figura 77 Etapas de um trabalho de conservação e restauro. 180

Figura 78 Reportagem publicada no Jornal a Folha de São Paulo 183 


\section{LISTA DE GRÁFICOS}

Gráfico 1 Tipo de Documentação nas Instituições 84

Gráfico 2 Atuação Profissional de 1970-1980 92

Gráfico 3 Atuação Profissional de 1980-1990 92

Gráfico 4 Atuação Profissional de 1990-2000 93

Gráfico 5 Atuação Profissional de 2000-2010 94

Gráfico 6 Solicitação e Execução de Trabalhos de Conservação e 95 Restauração

$\begin{array}{lll}\text { Gráfico } 7 & \text { Intervenções em obras dos artistas } & 102\end{array}$

Gráfico 8 Tipos de problemas freqüentes encontrados nas obras 111 


\section{LISTA DE MAPAS}

Mapa 1 Área Urbanizada 1930/49

Mapa 2 Área Urbanizada 1950/69.

Mapa 3 Centro Expandido de São Paulo. 


\section{LISTA DE TABELAS}

Tabela 1 Eventos realizados em São Paulo......................................... 158

Tabela 2 Eventos realizados fora de São Paulo.................................. 159

Tabela 3 Artigos em revista do CPC USP.......................................... 160

Tabela 4 Artigos em Anais da ABRACOR ........................................... 162

Tabela 5 Artigos na Revisa ARC.................................................... 164 


\section{LISTA DE ABREVIATURAS E SIGLAS}

ABER Associação Brasileira de Encadernação e Restauro

ABRACOR Associação Brasileira de Conservadores e Restauradores de Bens Culturais

ACCR Associação Catarinense de Conservadores e Restauradores

ACOR RS Associação de Conservadores e Restauradores de Bens Culturais do Rio Grande do Sul

ACOR.IT Associação de Conservadores e Restauradores de Bens Culturais de Curitiba

APCR Associação Paulista de Conservadores e Restauradores de Bens Culturais

CECOR Centro de Conservação e Restauração de Bens Culturais Móveis

CPC/USP Centro de Preservação Cultural da Universidade de São Paulo

CONDEPHAAT Conselho de Defesa do Patrimônio Histórico Arqueológico, Artístico e Turístico do Estado de São Paulo

CONPRESP Conselho Municipal de Preservação do Patrimônio Histórico, Cultural e Ambiental da Cidade de São Paulo

DPH Departamento do Patrimônio Histórico da Prefeitura Municipal de São Paulo

EBA Escola de Belas Artes da Universidade Federal de Minas Gerais

ENBA Escola Nacional de Belas Artes - RJ

GCl Getty Conservation Institute.

ICCROM International Centre for the Study of the Preservation and Restoration of Cultural Property

ICOM International Council of Museums

ICOMOS International Council on Monuments and Sites

ICR Istituto Centrale per II Restauro

IEPHA/MG Instituto Estadual do Patrimônio Histórico e Artístico de Minas Gerais 
IPHAN Instituto do Patrimônio Histórico e Artístico Nacional

MEC Ministério da Educação e Cultura

SEC Secretaria Municipal de Cultura

UNESCO United Nations Educational Scientific and Cultural Organization

VITAE Apoio a Cultura, Educação e Promoção Social 


\section{SUMÁRIO}

INTRODUÇÃO

PARTE I: ARTE MURAL

CAPITULO I: A Arte Mural na Cidade de São Paulo 6

1.1 Uma revisão da literatura: a visão de críticos e historiadores sobre a arte mural

1.2 A arte mural no espaço arquitetônico e no espaço urbano 13

$\begin{array}{ll}1.3 \text { Mapeamento das obras } & 17\end{array}$

PARTE II: A PRÁTICA DA PRESERVAÇÃO 21

CAPITULO II: As Bases Teóricas e a Definição de Conceitos 22

2.1 Conservação e Restauração Aspectos Teóricos 22

2.2 A Arte Mural como bem integrado 39

2.3 Cartas e Documentos Internacionais $\quad 44$

CAPITULO III: O Exercício da Prática 58

3.1 A Prática Institucional 58

3.1.1 A Institucionalização da Preservação 58

3.1.2 Preservação de Bens Integrados $\quad 70$

3.1.3 Inventário e Catalogação $\quad 76$

3.1.4 Documentação $\quad 79$

3.2 A Prática do Setor Privado 88

3.2.1 Metodologia e Pesquisa de Campo 88

3.2.2 Agentes Executores 90

3.2.3 Agentes Financiadores e Patrocinadores 96

3.3 Conservação e Restauração da Arte Mural - Considerações sobre a 101

Prática

3.3.1 Problemas da atuação prática 101

3.3.2 Critérios de Avaliação das obras $\quad 112$

$\begin{array}{ll}\text { 3.3.3 Estudos de casos } & 116\end{array}$ 
CAPITULO IV - O Profissional de Conservação e Restauração 146

4.1 Formação, Atuação, Reconhecimento da profissão 146

4.2 Interdisciplinaridade $\quad 155$

CAPITULO V -Qualidade em Intervenções de Conservação e Restauração 169

5.1 Conceito de Qualidade $\quad 169$

5.2 Conceito de Gestão 171

5.3 Aplicação em Conservação e Restauração 175

$\begin{array}{ll}\text { CAPITULO VI - Diretrizes } & 181\end{array}$

6.1 Novas perspectivas e desafios da preservação da arte mural 181

6.2 Diretrizes 187

CONSIDERAÇÕES FINAIS 189

$\begin{array}{ll}\text { REFERÊNCIAS BIBLIOGRÁFICAS } & 197\end{array}$

$\begin{array}{ll}\text { ANEXOS } & 207\end{array}$

$\begin{array}{ll}\text { ANEXO I Questionário para a pesquisa } & 208\end{array}$

ANEXO II Princípios do ICOMOS para a Preservação e Conservação - 221 Restauração das Pinturas Murais (2003)

ANEXO III Código de Ética do Conservador-Restaurador 228 


\section{INTRODUÇÃO}

A arte mural tem sido abordada sob diferentes aspectos por vários autores desde a sua relação com a arquitetura e a sua inserção no espaço urbano, até o seu caráter social, político e artístico.

Alguns autores têm trabalhado o tema dentro do universo geral da historiografia da arte enfatizando apenas alguns períodos de desenvolvimento desta arte, mas uma produção específica voltada ao tema e com um panorama geral desta arte em território nacional não foi encontrada. Somente alguns catálogos foram elaborados com estudos específicos sobre determinadas obras ou artistas e com a ênfase em uma divulgação mais visual e ilustrativa, do que propriamente em uma reflexão mais profunda sobre o tema.

Fazendo uma revisão da bibliografia sobre a arte mural encontramos em muitos trabalhos acadêmicos uma abordagem também semelhante, com a ênfase dada à obra arquitetônica e a sua relação como contexto urbano, sócio-cultural, econômico e político e feita apenas uma menção ao mural nela inserido.

Grande parte dos autores se dedica, em suas respectivas produções, a uma análise estilística e iconográfica das obras murais, sem se ater às questões técnicas de execução ou de um histórico de intervenções, de conservação e restauro, o que também é parte integrante da história da obra e muitas vezes determinador de possíveis alterações em sua estética ou iconografia originais.

A produção bibliográfica realizada evidencia e privilegia, portanto, as questões estéticas e históricas e não propriamente as questões materiais e técnicas e nem de um histórico de intervenções realizadas na arte mural paulistana.

Essa ressalva, todavia, não exime a importância de trabalhos com este tipo de abordagem, que se inserem em um contexto de história da arte, mas pelo contrário, destaca outra visão também significativa ou de igual importância, que possa ser dada a esses estudos da arte mural. Abordagem que, até agora, não tem sido desenvolvida no contexto paulistano e paulista e, possivelmente de forma mais ampla, no contexto nacional, já que grande parte das representações deste tipo de arte se encontra na cidade de São Paulo.

Por este motivo, este estudo procura identificar o pensamento preservacionista da arte mural através das intervenções de profissionais atuantes na área de conservação e restauro de obras murais na cidade de São Paulo. 
A escolha deste local se deve ao fato de que somente poucas cidades do nosso país tiveram uma produção significativa desse tipo de arte e, entre elas está a cidade de São Paulo, que se destaca por apresentar um grande número de murais de considerável importância, de diferentes períodos e também por concentrar a produção de grande parte dos artistas que a essa arte se dedicaram.

O recorte escolhido para objeto de estudo corresponde aos trabalhos de arte mural realizados no período entre 1930 e 1960, período no qual houve uma intensa produção dessa arte na cidade de São Paulo, desenvolvida por artistas que estiveram vinculados ao Grupo Santa Helena.

Consideramos também para efeito de estudo o período correspondente ao final do século $X X$ e início do século $X X I$, que atualmente estamos vivenciando, como sendo o marco destas intervenções. Esse período coincide com o crescimento e incentivo das atividades de conservação e restauração e, também, com o crescimento das preocupações com a preservação da arquitetura moderna.

Um dos principais motivos impulsionadores da realização desta pesquisa foram as evidências constatadas na pesquisa realizada na etapa anterior a este trabalho, correspondente a execução da dissertação de mestrado ${ }^{1}$ cuja proposta era de fazer um inventário das obras remanescentes desses artistas. A aquisição de informações representou nessa fase uma verdadeira maratona em busca de dados, tanto em instituições públicas, quanto nos locais onde as obras estavam.

O atual trabalho tem por objetivo contribuir para o estudo da prática da preservação da arte mural em São Paulo, enfocando os conceitos que dirigem a preservação da arte mural do ponto de vista teórico e a sua implantação na prática da conservação.

Essa reflexão sobre o histórico da preservação e das intervenções realizadas na arte mural poderá contribuir para a elaboração de diretrizes para futuros projetos de conservação e restauro a serem realizados, bem como da possível implantação de uma política de conservação preventiva e integrada. A prática exigirá a participação de diferentes profissionais como o conservador-restaurador, o arquiteto, o engenheiro, o químico, o historiador da arte, etc, dentro de suas respectivas áreas de competências.

\footnotetext{
${ }^{1}$ Wilhelm, Vera R.B. A Arte Mural do Grupo Santa Helena: um Estudo para Preservação. São Paulo, Dissertação de Mestrado, FAU /USP, 2006.
} 
A constatação da inexistência de uma metodologia de registro e documentação que permitisse um acompanhamento mais minucioso das obras, tanto a nível institucional quanto da prática privada, gerou uma reflexão sobre o porquê desta situação. Nesta reflexão três questões iniciais foram formuladas sobre o tema:

1. O reconhecimento do valor cultural do objeto de estudo.

2. O interesse institucional sobre o tema.

3. A existência de profissionais responsáveis e qualificados para executarem o trabalho.

$\mathrm{Na}$ busca pelas respostas a estas questões, formulou-se uma hipótese e verificamos a necessidade de reunir informações que permitissem realizar as reflexões sobre a preservação da arte mural. A hipótese levantada para o desenvolvimento desta pesquisa relaciona-se à prática da preservação da arte mural como uma prática ainda fundamentada no empirismo, sem embasamento científico ou programas de atuação interdisciplinar que subsidiem a atuação de profissionais e fundamentem as intervenções de conservação e restauro.

O empirismo na prática da preservação da arte mural é a fonte de uma série de fatores que dificultam o conhecimento, a documentação, o resgate e a recuperação de referenciais da nossa arte e arquitetura.

Partindo dessa hipótese, destacamos alguns problemas a serem levantados que estariam diretamente vinculados a essa prática:

- Escassez e/ou inadequada documentação e registro das obras.

- Inexistência de legislação específica de tombamento.

- Prática desvinculada de programas de conservação integrados.

- $\quad$ Necessidade de uma padronização dos registros documentais e de intervenções nas obras.

- Escassez de definição da terminologia utilizada pelos profissionais na comunicação das práticas de intervenção.

- Formação de profissionais e qualificação de mão de obra.

Os problemas levantados decorrentes da prática realizada de forma empírica se tornam mais complexos à medida que essa atuação vai ganhando proporções cada vez maiores, principalmente com as iniciativas e incentivos financeiros existentes atualmente para a preservação, não só do ponto de vista institucional, 
mas também daqueles provenientes de empresas patrocinadoras que buscam associar o seu nome a preservação do patrimônio cultural.

A metodologia utilizada para a realização deste trabalho incluiu três etapas. Na primeira etapa foi realizada a coleta e análise da bibliografia sobre o tema, tanto a nível nacional como internacional. Tendo em vista que diferentes conceitos foram trabalhados ao longo desta pesquisa evidenciou-se a necessidade da utilização de uma bibliografia diversificada relacionada às áreas distintas.

$\mathrm{Na}$ segunda etapa foi realizada a coleta de material em fontes primárias (no local onde estavam as obras, com os proprietários e em instituições de preservação) e também a consulta às empresas e aos profissionais que trabalham na área, através de um questionário elaborado para esse fim e encaminhado a eles para preenchimento.

A partir dos dados coletados foi realizada a análise propriamente dita confrontando as hipóteses com as informações obtidas das diversas fontes e estruturando a reflexão sobre a prática, de forma a abranger as respectivas áreas envolvidas no processo.

A estrutura da tese foi dividida em três partes que incluem os tópicos necessários à fundamentação e argumentação da hipótese levantada.

A parte I é composta do capítulo um relativo à arte mural, objeto de estudo deste trabalho, evidenciando a sua relação com o ambiente arquitetônico e urbano e situando-a no espaço físico da cidade através do seu mapeamento.

A parte II refere-se à prática da preservação e é composta de dois capítulos, o primeiro onde se que estabelecem as bases teóricas e os conceitos necessários ao exercício da prática propriamente dita e o segundo sobre a implantação de uma prática institucional do patrimônio e dos bens integrados e, a prática do setor privado com algumas considerações sobre as intervenções de conservação e restauro realizadas na arte mural.

A parte III refere-se à normalização do processo e inclui três capítulos. Um capítulo relativo à formação de profissionais da área, à atuação e ao reconhecimento da profissão. O outro capítulo sobre a qualidade em intervenções de conservação e restauro e o último relativo às diretrizes para preservação da arte mural. No final são traçadas algumas considerações sobre ao trabalho desenvolvido e anexado o material utilizado como parte da pesquisa. 
PARTE I: ARTE MURAL 


\section{CAPITULO I: A Arte Mural na cidade de São Paulo}

\subsection{Uma revisão da bibliografia: a visão de críticos e historiadores sobre a arte mural.}

Dentro do universo amplo da arte mural produzida em São Paulo e considerando a diversidade de artistas e também a dimensão do território optamos, por questões práticas, realizar um recorte temporal, espacial e de artistas para que uma análise pudesse ser realizada.

O objeto de estudo deste trabalho restringiu-se, portanto, a produção mural na cidade de São Paulo do período que abrange as décadas de 1930 a 1960, dos artistas que integraram o Grupo Santa Helena e, das respectivas intervenções nelas executadas.

A arte mural é abordada por diversos autores que geralmente destacam a produção realizada no início do século XX, quando as primeiras manifestações por uma arte, livre da rigidez acadêmica, começaram aparecer no cenário nacional, com alguns expoentes da classe artística e da elite paulista na Semana de 22, estendendo-se até a década de 1960.

Embora as abordagens variem e exista uma divergência entre críticos sobre alguns aspectos, pode-se dizer que, em suas respectivas análises muitos deles buscam estabelecer as possíveis relações existentes entre a nossa arte mural e a pintura mural mexicana, que teve grande repercussão no cenário internacional, relacionando a arte mural a uma arte social ou arte urbana.

A seleção considerou não só a bibliografia existente sobre os respectivos artistas, mas também alguns textos escritos pelos críticos de arte na época da produção das obras com a finalidade de compreender melhor a visão no período e a repercussão da obra e seu significado no contexto.

Críticos como Mário de Andrade, Mario Pedrosa, e historiadores da arte e autores como Aracy Amaral, Annateresa Fabris, Walter Zanini, Alice Brill, Maria Cecília França Lourenço, foram considerados no estudo.

A consulta realizada a outros autores como: Lisbeth Rebollo Gonçalves, Walter Zanini, Elza M. Ajzenberg, Lorenzo Mammi, etc, que escreveram biografias sobre determinados artistas foram importantes para verificarmos não só o material existente, mas o tipo de abordagem dada ao tema. 
Os trabalhos apresentam informações sobre a arte mural, com maior ou menor grau de profundidade, num contexto mais amplo e geral das produções artísticas dos respectivos artistas, pois vários dos autores, não elaboraram textos com uma ênfase especifica sobre a produção mural.

Somente nesta ultima década é que têm sido desenvolvidos alguns trabalhos acadêmicos enfocando também alguns períodos ou artistas e, portanto, pela seqüência de trabalhos que tem aparecido parece estar crescendo o interesse por este tipo de arte atualmente.

Talvez isso venha ocorrendo em função da ampliação da percepção e sensibilização das pessoas em relação a essa arte, da possibilidade de novas abordagens com estudos de caráter inovador, relacionados ao aperfeiçoamento dos estudos já existentes, ou mesmo em função do próprio distanciamento temporal das obras em relação aos dias de hoje, nos permitindo uma compreensão e análise do seu significado ou função no contexto geral da história da arte.

Mario de Andrade, amigo e grande entusiasta e admirador da obra de Candido Portinari escreve em seu ensaio sobre o artista, em $1944^{2}$, referindo-se ao caráter experimental da obra do artista, mais do que propriamente do caráter revolucionário de sua obra. (GUIDO,1984)

Candido Portinari foi um dos artistas que teve destaque internacional com esse tipo de arte e que se tornou referência para outros artistas nacionais ao realizar suas obras no Ministério da Educação e Saúde (MES), quer pela temática abordada em sua obra, quer pela sua expressão plástica.

A produção artística de Portinari bem como as suas obras murais foram objeto de análise de vários críticos e são significativas para compreensão da eventual influência da arte mural mexicana em sua obra e da influência da sua produção em outros artistas que aqui se dedicaram a arte mural. ${ }^{3}$

Mario Pedrosa (1901-1981) entre outros, diz em seu texto Portinari - de Brodósqui aos Murais de Washington ${ }^{4}$ que, o contato de Portinari com a arte

\footnotetext{
2 GUIDO, Maria Christina. Portinari segundo Mário. Ensaio publicado na revista do patrimônio histórico IPHAN, no 20 Ano de 1984, p 64-93.

${ }^{3}$ ZANINI,(1991) é um dos autores que destaca a influência de Portinari na obra de Clovis Graciano, assim como LOURENÇO (1995).

${ }^{4} \mathrm{O}$ artigo faz parte da coletânea de textos publicados por Mario Pedrosa em periódicos, que foram reunidos no livro Dos Murais de Portinari aos Espaços de Brasília, organizados por Aracy Amaral.
} 
mexicana só veio ocorrer por volta de 1935 e que a arte mexicana já se encontrava em atividade.

A diferença entre a arte mural de Portinari e a arte mural Mexicana, segundo PEDROSA (1981) é tanto em cronologia, como em estética e em propósito. A arte mural mexicana tinha o objetivo de exprimir a ideologia da revolução mexicana, mas a de Portinari, segundo o autor, era resultado da intenção em resolver questões técnicas e estéticas inerentes a sua evolução artística e a uma necessidade de expressão de monumentalidade.

A semelhança entre as duas artes, como também mencionada é que elas representavam uma reação aos limites da técnica da pintura de cavalete. Ele reconhece em Portinari uma influência da expressividade e de aspectos compositivos de Diego Rivera (1886-1957), todavia acredita que a qualidade estrutural de Portinari supera os afrescos mexicanos. Destaca ainda que o caráter social e de crítica social através da arte e da literatura é reflexo da conturbada época política vivida no período. Para Mario Pedrosa:

\begin{abstract}
Outras diferenciações e meios, de fins e de tradições e de condições determinam também as diferenças na maneira de resolver o problema do mural nos dois países. No México esta pintura constitui uma profunda tendência generalizada, social, criando uma verdadeira escola e um estilo nacional. No Brasil, porém, ela não teve esse caráter generalizado, limitada que ficou a uma fase de evolução de um pintor. Não chegou até aqui a ser um movimento. Ao artista brasileiro, este gênero se apresentou, sobretudo como um meio de desenvolver em campo mais vasto as qualidades de estrutura e todas as possibilidades da plástica monumental a que havia chegado em sua pintura a óleo. (PEDROSA, 1981, p. 14)
\end{abstract}

Todavia, como analisa AMARAL (2003), Mario Pedrosa não pode desconsiderar a influência da obra de Picasso na produção de Portinari, tanto no desenho como na paleta na década de 40. A autora ainda evidencia o contato de Candido Portinari (1903-1962) e Emiliano di Cavalcanti (1897-1976) com as obras murais mexicanas cujo movimento se iniciou em 1922.

Apesar de discordar de Mario Pedrosa, AMARAL (2003) reconhece e enaltece a influência forte do muralismo mexicano na obra mural de Portinari que abraça o tema do trabalhador rural. Destaca também o contato de Portinari com a obra de Picasso no Museu de Arte Moderna, no período em que ele esteve em NY, que também irá marcar os seus desenhos, as formas e a dramaticidade na expressão de suas obras. 
Di Cavalcanti, segundo a autora, deixa transparecer em suas obras, pelas formas arredondadas das figuras, a admiração pelo muralismo mexicano e por Diego Rivera. Ele tem também a consciência da função social do artista e pede a participação do mesmo enquanto cidadão. A preocupação social permanecerá e em sua arte nos anos 30 .

Di Cavalcanti teve também um contato com a obra de Léger, quando esteve em Paris nos anos 1923-1925, como escreve AMARAL (2006), período em que as primeiras experiências com mural eram realizadas por Fernand Legér.

Em 1925 Legér desenvolve juntamente com Mallet-Steven o projeto da Embaixada e o do Pavilhão Espirito Novo com Le Corbusier e é, segundo ele, que a partir daí surge essa colaboração entre artista/pintor e arquiteto.

Para Legér é o arquiteto, portanto, que deverá escolher o local onde a pintura será colocada para que ela seja dinâmica ou estática, decorativa ou destrutiva. A obra mural, segundo ele, é uma demanda em edificações modernas. "O arquiteto se entenderá com o pintor para situá-la e dosar seu interesse. Ela pode ser acompanhamento da parede ou destruição da parede." (LEGER, 1989, p.109)

É nesse espírito dos ideais modernos que as obras de Portinari em fins dos anos 30 impulsionaram a execução de trabalhos artísticos integrados à arquitetura, seguindo os princípios de Le Corbusier, introduzidos no nosso contexto por Lucio Costa $^{5}$ onde as três artes pintura, escultura e arquitetura colaboraram entre si.

Le Corbusier em seu texto $A$ arquitetura e as Belas Artes menciona que "[....] em certas ocasiões, a arquitetura pode satisfazer às suas tarefas e aumentar o prazer dos homens através de uma colaboração excepcional e magnífica com as artes maiores: pintura e estatuária" (COSTA, 1984, p. 62)

Influenciados pelas idéias de Le Corbusier, os arquitetos modernistas iniciaram parcerias e colaborações com artistas para integrar a arte à arquitetura, principalmente a escultura e a arte mural. Para ele a pintura tem seu local específico, em condições particulares "[...] há paredes incomodas, impostas - ou tetos ou solos - por razões intempestivas alheias à disciplina arquitetural." (COSTA, 1984, p. 64) onde o pintor poderá desempenhar seu papel dentro da produção arquitetônica, permitindo que a pintura faça saltar a parede ou dinamitá-la.

\footnotetext{
${ }^{5}$ Lucio Costa é quem irá divulgar no contexto brasileiro as idéias de Le Corbusier e as discussões estabelecidas na reunião de 1936 em Roma em torno do tema Arquitetura e Belas Artes.
} 
No Rio surge a parceria do arquiteto Oscar Niemeyer com o artista Candido Portinari, já, em São Paulo, o arquiteto Rino Levi (1901-1965) tem como colaborador Emiliano Di Cavalcanti que inicia uma fase de desenvolvimento desse tipo de arte mural com a construção do Teatro Cultura Artística.

A visão de Portinari como 'pintor oficial' ou 'pintor histórico do século XX' do regime de Vargas como menciona AMARAL (2006) é questionada pela obra de FABRIS (1990). Ela toma como base uma abordagem social e procura destacar o papel do artista na crítica ao poder em função de seu envolvimento com a política, o seu engajamento com o Partido Comunista em 1945.

Embora em São Paulo as primeiras experiências murais já houvessem surgido no início dos anos $30 \mathrm{com}$ a iniciativa do artista modernista Antonio Gomide e a atuação de Fulvio Pennacchi nos anos 30 e 40, LOURENÇO (1995) considera ter a obra de Portinari influenciado a produção mural de Clovis Graciano, artista atuante em São Paulo, em função dos primeiros contatos de Portinari com o grupo ainda no tempo da Família Artística Paulista, em 1935, no Edifício Santa Helena.

A arte mural de Picasso e também de Portinari que, segundo a autora, influenciou a produção mural de Clovis Graciano irá se refletir com maior intensidade a partir dos anos 50 quando Clovis retorna de viagem da Europa e inicia seus murais nos anos seguintes em diferentes obras de arquitetos ligados ao movimento moderno na cidade de São Paulo ${ }^{6}$.

A cidade se encontrava em expansão e com os trabalhos para a comemoração do IVo centenário, em 1954, já em desenvolvimento. LOURENÇO (1995) Considera que um marco significativo da transformação do moderno em cultura é a confluência de pintores, escultores e arquitetos para implantação de obras em espaços públicos.

A autora faz também um panorama da atuação de Clovis Graciano no meio artístico e destaca a influência do painel Tiradentes (1949) de Candido Portinari na obra de Clovis, que bastante engajado no meio artístico, participa de vários trabalhos, deixando a produção de uma série de murais na cidade e também fora dela. Para a autora, o mural é a obra que proposta com a arquitetura é

\footnotetext{
${ }^{6}$ Dentre os arquitetos que estabeleceram parceria com Clovis Graciano para a execução de murais em suas obras de arquitetura estão: Adolf Franz Heep (1902-1978), Oswaldo Corrêa Gonçalves (1917-2005), Roberto José Goulart Tibau (1924-2003), Jacques Pilon (1905-1962), Abelardo R. de Souza (1908-1981).
} 
representativa de harmonia e fruição para o usuário, tem seu local específico e sua monumentalidade. O mural surge com objetivo de levar a arte ao público, torná-la acessível.

Ela também considera importante na divulgação desta arte no meio urbano a repercussão das obras mexicanas no Clube dos Artistas Modernos (CAM) por ocasião de uma palestra de David Alfalo Siqueiros em 1933 no local, além da reação dos participantes do Congresso Panamericano de Arquitetos realizados no México em 1952.

Diferentemente do que ocorreu no Rio de Janeiro, a fase de realização dos murais de caráter "oficial" em São Paulo ocorreu nos anos 50 com a produção de Clovis Graciano e também, de alguns outros artistas que não tinham relação com o antigo Grupo Santa Helena, em uma série de obras executadas pelo governo numa fase de expansão da cidade. Talvez possa se estabelecer neste caso, uma certa semelhança com a obra de Portinari sob o aspecto da encomenda oficial, da referência formal e estética à uma produção bem sucedida como a de Portinari, da semelhança de origem proletária o que permitiu uma identificação maior com o artista e da relação de colaboração com os arquitetos seguidores dos princípios modernistas, já que ambos tinham uma boa circulação nos meios artísticos da época.

Em relação aos outros antigos componente do Grupo Santa Helena, Volpi, Rebolo, e Zanini, que também trabalharam com arte mural, pode-se dizer que entre os autores que escrevem sobre as biografias desses artistas parece haver um consenso quanto a produção mural dos respectivos artistas. A produção restringe-se a fase inicial, quando o ofício da arte era o seu meio de subsistência e pintavam as obras feitas por encomenda, obras murais artísticas e decorativas. O comentário feito por autores sobre as respectivas obras é restrito, excetuando o texto de ZANINI que fornece algumas informações interessantes sobre algumas das obras e sobre os artistas.

Na obra Volpi, MAMMI (2001) inicia seu texto evidenciando que existe uma diferença clara para o artista Alfredo Volpi do que era arte e do que era artesanato, embora existisse uma convivência entre a arte e o artesanato de forma pacífica na vida do artista. O texto analisa, portanto, a evolução da carreira artística dele sem enfatizar a fase em que o artista participou destas atividades de execução de 
pinturas murais, apenas citando a sua colaboração com os colegas como Rebolo e Zanini em algumas obras.

As obras do setor de pediatria do Hospital São Luís Gonzaga em 1949, segundo o autor, não passaram de um exercício artesanal da profissão e não tiveram um significado de trabalho de artista; já as obras da Capela Cristo Operário em 1951 o autor destaca como sendo a primeira vez que Volpi pinta sobre parede como artista e não como decorador. A obra em Brasília para a Capela Nossa Senhora de Fátima é executada em 1958 e em relação à obra Mario Pedrosa diz que, ela poderia representar um caminho para a arte sacra moderna.

Em Rebolo AJZENBERG (1986, p. 26) reconhece que "Não há por parte de Rebolo a intenção de indicar a descontração de um lazer ou a preocupação de denúncia como nos trabalhos de Portinari." A intenção não era de fazer uma pintura de denúncia social, característica dos anos 40 , e sim dele seguir a sua produção, fiel a seus sentimentos e a expressão de uma arte de paisagem.

ZANINI (1976) destaca que o artista Mario Zanini realizou trabalhos murais em épocas diferentes e que prestou colaboração à Volpi desde 1927 e à Rebolo desde 1933 fazendo as decorações e auxiliou também Pennacchi e Graciano. O autor ainda menciona que desta atividade de ganha-pão nada resta. As encomendas de trabalho eram feitas geralmente a seus colegas que tinham mais facilidade de conseguí-las, daí a participação desse artista em outras obras murais.

Ainda em sua análise sobre a arte nas décadas de 30 e 40 ZANINI (1991) menciona que, a temática social não era algo exterior à vivência dos artistas do grupo era inerente a obra deles e, sobre a produção mural ele destaca e especifica algumas obras ainda remanescentes dos artistas do grupo.

No caso do artista Fulvio Pennacchi, cuja produção é intensa, o autor Valério Pennacchi em seu livro Pennacchi Pintura Mural nos da uma visão geral da obra mural do artista dentro da sua produção. Os capítulos são divididos segundo a técnica empregada e apresentam a descrição das obras, locais onde foram realizadas e alguns comentários sobre procedimentos técnicos executados.

O autor reconhece a influência de artistas italianos na obra mural de Pennacchi, mas não menciona a existência de uma ideologia política e da exploração da temática social em sua obra, nem a influência de Portinari na produção mural do artista. 
As diversas abordagens citadas destacam, portanto, a evolução das respectivas produções dos artistas em um contexto mais amplo da história da arte e estabelecem os laços existentes ou não, das obras murais com as obras de Portinari e ou com a dos muralistas mexicanos, mas não introduzem aspetos de uma evolução histórica e material das obras, nem mesmo de possíveis intervenções realizadas nessas produções.

\subsection{A arte mural no espaço arquitetônico e no espaço urbano}

A arte mural faz parte do habitat humano desde os tempos mais remotos e, por ser parte integrante da arquitetura mantém através da sua localização espacial, iconografia e técnica uma relação com o ambiente do qual faz parte.

A arte mural está estritamente vinculada à arquitetura ou mesmo ao espaço urbano, pois o seu suporte é a parede ou o muro.

A execução deste tipo de arte na arquitetura demonstra a vinculação com a estrutura arquitetônica, com as técnicas construtivas e com os elementos de composição, mas principalmente a vinculação com aspectos relacionados aos usos, costumes e ao modo de viver da sociedade em determinada época e cultura. Portanto, os aspectos iconográficos, assim como a técnica e os materiais acompanham as necessidades das sociedades.

A definição de 'mural' no dicionário de arquitetura brasileira é "Relativo ao muro. Também modernamente designa-se assim a pintura executada em muro ou parede, de grandes dimensões". CORONA e LEMOS (1972, p.329). Os autores utilizam o termo 'painel' na arquitetura para denominar as manifestações artísticas feitas com diversos materiais em grandes dimensões, todavia incluindo pinturas sobre suporte de madeira e tela, o que não constitui o objeto de estudo deste trabalho.

O termo aqui usado pela autora, portanto, será arte mural para designar não somente a pintura mural, mas também as outras técnicas e materiais usados na execução da arte sobre o muro ou parede de modo a abranger um número maior de 
obras e formas de expressão que pudessem melhor definir a produção dos artistas em diferentes períodos. ${ }^{7}$

Essas características intrínsecas se mantêm ao longo dos vários anos na nossa arte mural, variando em intensidade ou predominância de um ou outro aspecto de acordo com a época e local.

A produção do Grupo Santa Helena relativa a este tipo de arte restringiu-se a atuação de alguns de seus integrantes como Mario Zanini, Alfredo Volpi, Francisco Rebolo Gonsales, Fulvio Pennacchi e Clóvis Graciano e foi executada num período entre 1930 a 1960. Alguns destes artistas tiveram sua produção mural restrita a fase de "pintor de parede" ou "pintor decorador" sendo, portanto, possível atribuir a essa produção um caráter de arte mural "decorativa".

A arte mural desenvolvida por eles poderia ser dividida em duas fases: a primeira com a intensa produção das pinturas artísticas e decorativas feitas por encomenda e meio de sustento de alguns deles como Rebolo, Volpi, Zanini e parcialmente de Pennacchi, compreendendo os anos entre 1930 até meados de 40; e uma segunda fase, após 1940 e até fins dos anos 60 quando dois artistas deram continuidade a essa arte e despontaram com uma produção individual intensa de murais em São Paulo. Embora com características formais, técnicas e de períodos de atuação distintos, se destacaram como representantes desse tipo de arte os artistas Fulvio Pennacchi e Clovis Graciano.

A década de 1930 caracteriza-se pelas mudanças econômicas sociais e políticas ocorridas no exterior com a crise da Bolsa em 1929. Crise que teve repercussões aqui abalando a economia agrária e exportadora do café, reduzindo preços e diminuindo a produção, cuja queda reduziu também os serviços e atividades que dependiam da economia cafeeira e geraram também a redução das importações dos materiais. Porém, essas mudanças acarretaram ao mesmo tempo uma aceleração do processo de industrialização para tentar suprir o mercado interno.

Além disso, as mudanças ocorridas internamente na política, com a revolução de 1930 e posteriormente em 1937 com a instauração do Estado Novo, tiveram repercussão na vida social e artística.

\footnotetext{
${ }^{7}$ Ficam excluídas pela autora as pinturas executadas sobre suporte de madeira ou tela de grandes dimensões e anexadas à parede, diferentemente do que fazem os autores Corona e Lemos em sua obra, incluindo-as e adotando o termo painel.
} 
Nesse período, no campo das artes, as idéias de vanguarda, introduzidas em nosso meio artístico pelos expoentes da Semana de 22, buscavam a ruptura com o academicismo e a introdução de uma nova expressão plástica, cuja fonte de inspiração viria da exaltação das nossas raízes. Essas novas idéias e expressões plásticas estavam abrindo espaço para as preocupações sociais que tiveram predominância na arte nesse período.

Nos anos 30, o grupo de modernistas passou a dividir o ambiente artístico com os outros grupos que surgiram, alguns sem vínculo ideológico, mas apenas imbuídos de uma necessidade de expressão e do exercício prático da sua arte sem, contudo, manter a rigidez característica da academia e nem a rebeldia da vanguarda modernista, é o caso dos artistas da Família Artística Paulista, posteriormente denominada de Grupo Santa Helena.

No campo arquitetônico, em São Paulo, já despontavam as primeiras manifestações de uma arquitetura moderna, com a produção de Gregório Warchavchik na década de 1920 e também de Rino Levi (1901-1965) e Flávio Resende de Carvalho (1899-1973) que deixaram suas marcas com suas novas idéias e experiências vivenciadas nas respectivas formações em solo Europeu.

No Rio de Janeiro a alterações no campo arquitetônico se processavam dentro a Escola Nacional de Belas Artes (ENBA), principalmente a partir do convite feito pelo jurista Francisco Campos a Lucio Costa para assumir a direção da escola, sendo ele nomeado em oito de dezembro de 1930 (BRUAND, 2008, p.72-73). As alterações ganharam ainda mais vulto após a visita de Le Corbusier, em 1936, ao Brasil e sua participação no projeto do Ministério da Educação e Saúde com sua crescente defesa dos princípios da arquitetura moderna.

Foi através da arquitetura que alguns artistas tiveram a oportunidade de tornar evidentes suas obras murais como Candido Portinari (1903-1962), nascido na cidade de Brodowski em São Paulo. Ele foi um dos artistas que, após retornar de viagem a Europa em 1931 e de conseguir um prêmio de menção honrosa em exposição de arte moderna do Instituto Carnegie nos EUA, foi convidado também por Oscar Niemeyer para participar das obras arquitetônicas em desenvolvimento na época e conseguiu destaque com sua produção artística nas edificações da arquitetura moderna nacional, tanto no Rio de Janeiro na sede do Ministério da Educação, o Palácio Gustavo Capanema (1936-1945), como em Belo Horizonte na 
Igreja de São Francisco de Assis na Pampulha (1942), no Pampulha late Clube, e também no exterior onde colaborou com quatro obras na Feira Mundial de Nova York, EUA (1939) e na seção Hispânica da Biblioteca do Congresso em Washington (1941-1942).

A repercussão da sua obra ocorreu também em São Paulo, pois a produção dos azulejos destinados a vários dos murais do artista foi realizada na firma criada para essa finalidade, em 1940, pelo artista Paulo Rossi Osir. A empresa denominada Osirart contou com a colaboração de alguns artistas integrantes do Grupo Santa Helena, como Alfredo Volpi e Mário Zanini.

Em 1947 é inaugurada também, em São Paulo, a empresa Vidrotil criada para atender a demanda crescente da execução de murais artísticos que passaram a ser produzidos na cidade dando, então, um suporte técnico a essa produção e introduzindo um material novo na arte mural, a pastilha de vidro.

A disseminação da arte mural pela cidade foi o resultado da parceria estabelecida entre arquitetos e artistas para a execução de murais nas edificações de distintos usos num período de crescimento da cidade.

A presença deste tipo de arte nos ambientes construídos interna e externamente e o acesso restrito a algumas obras dificulta o conhecimento da produção artística desta arte e o reconhecimento da importância dela no contexto arquitetônico e artístico paulistano.

A possibilidade de acesso e visualização desses trabalhos só ocorreu em um período posterior, entre 1945 a 1960, quando os ideais modernistas passaram a predominar no cenário da arquitetura. Os arquitetos responsáveis pela introdução destes princípios passaram a contar com a colaboração de artistas na execução de suas obras e a produção artística passou então a se voltar para a visão do público passante, transeunte, sendo realizada em edifícios públicos e ou espaços de livre acesso e executadas também em paredes externas das edificações.

Altera-se, portanto, não só a temática como também as técnicas de execução deste tipo de arte e os materiais empregados pelos artistas. Os murais externos passam a ser realizados com materiais semelhantes aos utilizados em revestimentos arquitetônicos. 
A maioria dos artistas que desenvolveram esse tipo de trabalho em parceria com os arquitetos, já eram artistas importantes na época ou adquiriram seu reconhecimento artístico com o passar dos anos.

A parceria consistia na realização de suas respectivas produções artísticas a convite do arquiteto, autor do projeto, ou de quem o encomendara ou patrocinara como proprietários, amigos, empresários e instituições, inserindo-as no espaço arquitetônico dentro de uma lógica espacial determinada pela própria arquitetura e de uma temática condizente com as funções da edificação ou do espaço onde estavam inseridas.

\subsection{Mapeamento das obras.}

Os murais escolhidos como objeto de estudo se encontram em edificações públicas e/ou privadas na cidade de São Paulo de uso residencial, comercial e cultural e sua distribuição segue a lógica normal do desenvolvimento urbano e da expansão da cidade.

As obras em sua maioria se localizam no centro ou próximas a ele e se estendem, posteriormente com o passar dos anos, ao longo dos eixos de circulação e nos bairros que foram sendo criados, ou naqueles bairros próximos do centro que estavam sendo reformulados, onde também ocorreu a verticalização das áreas.

Somente algumas dessas obras estão em edificações tombadas ou em edificações que estão em processo de tombamento. As obras de alguns artistas como Pennacchi e Clovis Graciano podem ser também encontradas em outras cidades ou mesmo estados, onde foram chamados para realização de trabalhos.

O inventário e mapeamento das obras na cidade de São Paulo foi iniciado na etapa anterior a este estudo, na fase da dissertação de mestrado quando foi elaborado um levantamento e registro através de ficha elaborada pela autora que incluía campos para o registro de informações sobre a arquitetura e também sobre a obra mural. O levantamento permitiu acompanhar possíveis intervenções realizadas nessas obras, nesta fase de estudos.

As obras remanescentes se encontram distribuídas por vários bairros da cidade como: Vila Nova Conceição, Ipiranga, Glicério, Tucuruvi, Vila Clementino, Vila 
Congonhas/Campo Belo, Jardim Europa, mas com maior concentração na área central na região de Higienópolis, dos Campos Elíseos, Consolação, etc.

No mapa a seguir é possível localizar algumas das obras escolhidas para estudo: 


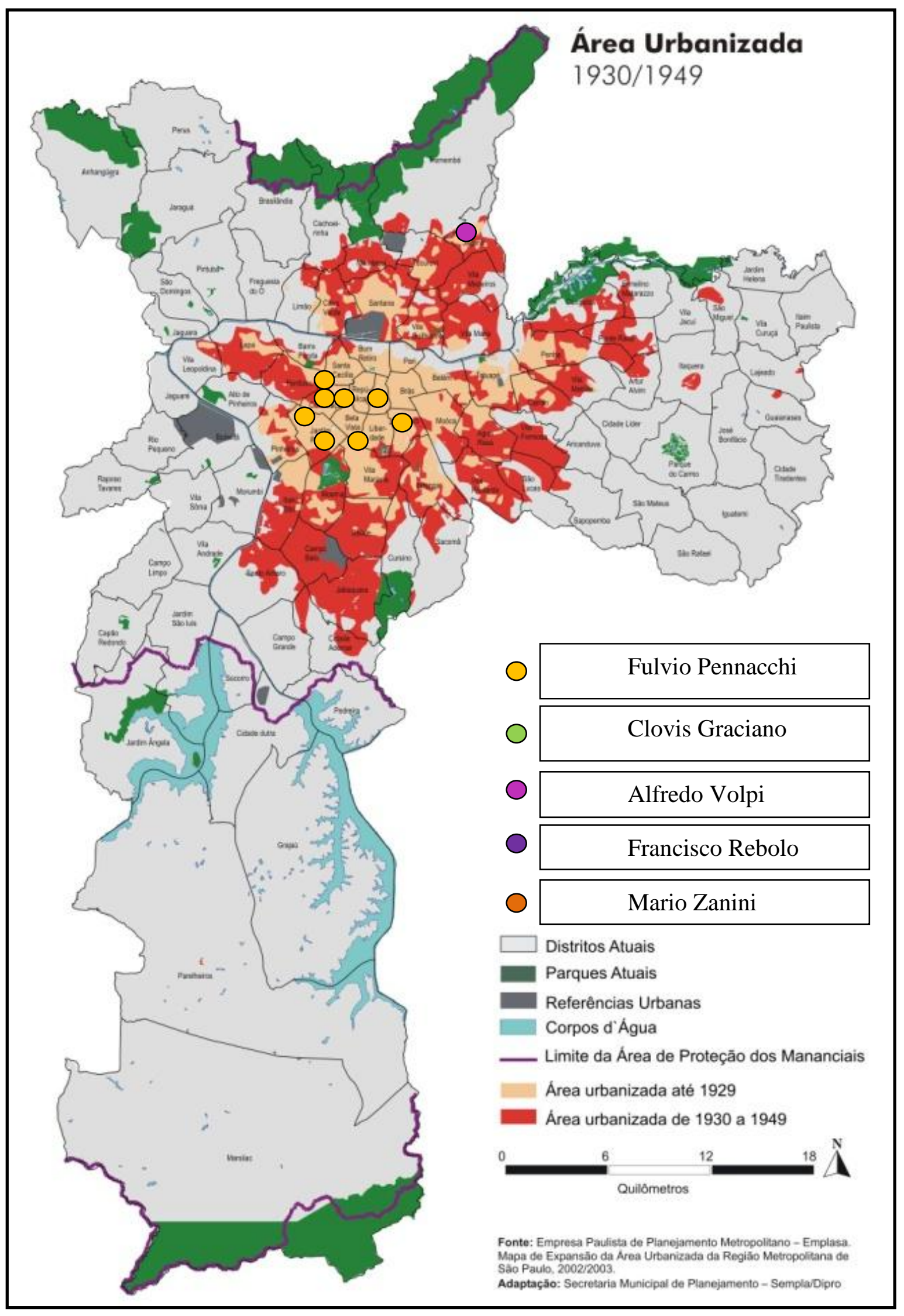

Mapa 1 - Localização das obras dos artistas em áreas urbanizadas em São Paulo Fonte: PMSP Disponível em: < http://smdu.prefeitura.sp.gov.br/historico demografico/img/mapas/urb-1940.jpg> 


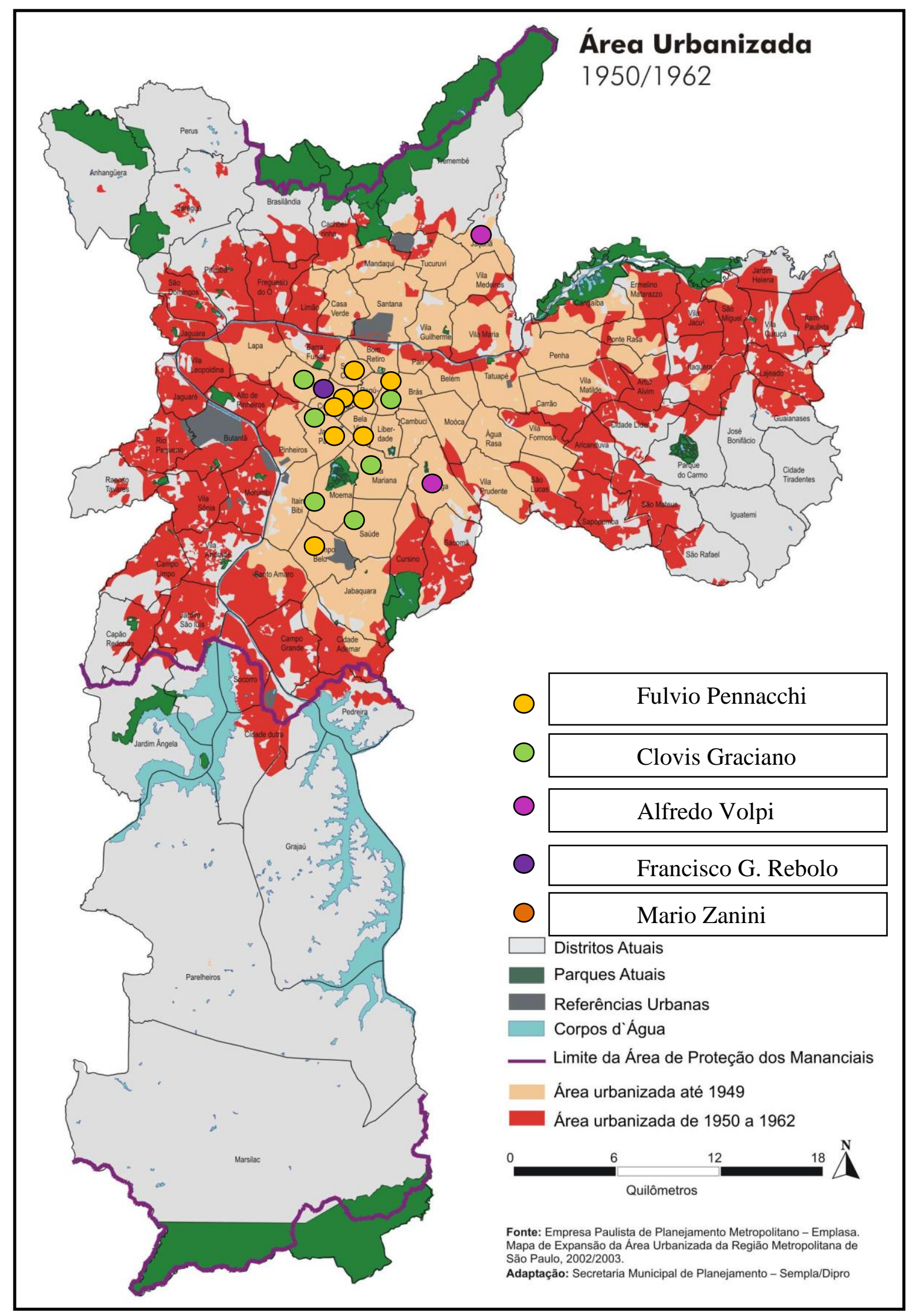

Mapa 2 - Localização das obras dos artistas em áreas urbanizadas de São Paulo

Fonte: PMSP Disponível em:<http://smdu.prefeitura.sp.gov.br/historico demografico/img/mapas/urb-19501960.jpg> 
PARTE II: A PRÁTICA DA PRESERVAÇÃO 


\section{CAPITULO II: As Bases Teóricas e a Definição de Conceitos}

\subsection{Conservação e Restauração Aspectos Teóricos.}

As crescentes atividades de intervenção de conservação e restauração que tem ocorrido nos últimos anos nas obras, nos levaram a refletir sobre a definição de conceitos e uso dos termos e a elaborar algumas considerações.

A demanda crescente por essas atividades não representa necessariamente uma evolução ou postura crítica dos profissionais atuantes frente ao patrimônio, mas leva em conta questões de diferentes naturezas: econômica, política, social, tendo como conseqüências em vários casos o comprometimento da qualidade técnica e a descaracterização do bem cultural a ser preservado.

Isso significa que, aspectos de ordem conceitual nem sempre estão claros ou são bem compreendidos por aqueles que atuam na área, envolvidos com a conduta prática, pela comunidade, ou mesmo pelas instituições de preservação responsáveis pela tutela do bem.

Partindo da hipótese de que a preservação da arte mural na cidade de São Paulo, iniciada no século XX é feita de forma empírica, sem o devido embasamento teórico, fundamentada em uma prática desvinculada de outros programas de conservação e, em muitos casos, ainda desenvolvida por artistas e artesãos (pintores de parede), devemos considerar alguns conceitos que possam elucidar essa argumentação e evidenciar a forma de atuação na realidade de São Paulo.

O empirismo no sentido etimológico se entende como o conhecimento adquirido através da experiência vivenciada e acumulada proveniente dos sentidos e sentimentos, diferentemente do conhecimento fundamentado na teoria e em um método que é o que caracteriza o conhecimento científico.

A existência de ambos, empirismo e conhecimento científico pode gerar conflitos e conseqüências nem sempre positivas, principalmente no campo da preservação, no qual a relação subjetividade e objetividade é que determinará práticas de restauração diferenciadas.

A perda gradativa dessa subjetividade, entendida aqui como preferências, gostos ou tendências e posições arbitrárias, já vem ocorrendo há tempos no exterior, e as práticas artesanais vêm dando lugar a objetividade do método e a trabalhos 
cada vez mais engajados com as ciências naturais e com o conhecimento adquirido pela interdisciplinaridade, pela inter-relação de diferentes campos profissionais em torno de um mesmo objeto de estudo, principalmente a partir da segunda metade do século $X X$.

No contexto internacional as discussões sobre as intervenções de conservação e restauração no campo arquitetônico se estendem já, desde o século XVIII e XIX, e evoluíram de forma diferente, fragmentando-se em tendências e linhas de atuação diversas e cujas discussões se mostraram mais intensas do que as discussões relativas à preservação das obras de arte (pintura, escultura, arte mural, etc.). Isso ocorreu em função de uma série de fatores que mantiveram a arquitetura num patamar de importância e destaque em relação às outras artes, tanto devido a sua dimensão, visibilidade e função, quanto pela própria estruturação de seu corpo disciplinar.

Diferentes posturas foram adotadas pelos seus expoentes ao longo destes séculos e evidenciadas numa prática de intervenção diversificada, que refletia as várias interpretações e conceitos sobre conservação e restauração e que, na realidade, diferem do que hoje compreendemos como conservação e restauração, pois nesse período, aquilo que era preservado abrangia mais as questões de ordem pragmática, do que a predominância de questões de ordem cultural.

Surgiu na França uma prática interventiva mais invasiva, em busca de um de um estilo, um estado ideal do edifício, como a prática de Viollet-Le-Duc (1814-1879) para quem "Restaurar um edifício não é mantê-lo, repará-lo ou refazê-lo, é restabelecer um estado completo que pode não ter existido nunca em um dado momento". (Viollet-Le-Duc, 2000, p. 29).

Seguindo uma linha oposta está a prática inglesa de John Ruskin (18191900), posteriormente seguida por William Morris (1834-1896) que tem um caráter mais conservativo e não intervencionista, respeitando a constituição material própria do edifício e a passagem do tempo na obra. Para John Ruskin, restaurar "[...] significa a mais total destruição que um edifício possa sofrer: uma destruição do qual não se salva nenhum vestígio: uma destruição acompanhada pela falsa descrição da coisa destruída." (RUSKIN, 2008, p. 79) 
O autor ainda expõe que o destino de todo monumento histórico é a ruína e a degradação progressiva, mas que esse fim pode ser retardado através da manutenção constante.

O restauro filológico introduzido pelo italiano Camilo Boito (1836-1914) estabeleceu uma postura intermediária entre estas duas vertentes e consolidou o monumento como documento histórico. Através do uso de métodos ele conseguiu atribuir à intervenção um caráter mais objetivo. Os sistemas normativos por ele desenvolvidos serviram de base para a política de preservação italiana. Ele também reuniu e desenvolveu alguns princípios que formariam a base da moderna teoria da restauração no século XX e que permaneceram evidentes ainda hoje. Segundo suas idéias, citadas por JOKILEHTO:

\begin{abstract}
Restauração foi baseada em um estudo aprofundado do edifício e suas modificações históricas, seguidas de um julgamento crítico do que conservar e o que remover. O objetivo era distinguir entre o original 'estado normal' do edifício e seu 'estado atual'. ${ }^{8}$ (JOKILEHTO, 2002, p. 201, tradução nossa).
\end{abstract}

Esses princípios foram trabalhados em sua obra Os Restauradores de 1884 que além da arquitetura abordava questões relacionadas à pintura e a escultura.

Os princípios buscavam enfatizar o valor documental dos monumentos, evitar a realização de acréscimos e renovações, completar as partes faltantes ou deterioradas com material diverso do original, fazer obras de consolidação estritamente necessárias, a mínima restauração, respeitar as várias fases do monumento, documentar e registrar as fases da intervenção, indicar e sinalizar as obras de intervenção com placas, material diferente ou formas geométricas.

Eles também refletiam, como menciona KUHL (2002), a sua visão do monumento como documento histórico e a ênfase que foi dada ao valor documental dos monumentos históricos no século XIX.

Camilo Boito também distingue a conservação da restauração, colocando-as em oposição. A primeira é considerada como algo necessário e que deve ser periódica para se evitar a restauração, esta é definida por ele como algo às vezes

\footnotetext{
8"Restoration was to be based on a thorough study of the building and its historical modifications, followed by a critical judgement of what to conserve, and what to remove. The aim was to distinguish between the original 'normal state' of the building and its 'actual state'."(JOKILEHTO, 2002, p. 201)
} 
necessário para salvar a obra e preservar a memória, da mesma forma que um cirurgião tem que intervir para salvar o paciente (BOITO, 2002).

Gustavo Giovanonni (1873-1947) com seu restauro científico, enalteceu a conservação do monumento como documento, exaltou a necessidade das pesquisas, da análise científica, conferindo importância aos valores históricos e documentais e compartilhando também com alguns princípios introduzidos por Boito, como os da reversibilidade e da distinguibilidade, deixar evidentes as intervenções realizadas. Ele destacou as questões urbanísticas relacionadas à preservação de centros históricos, do contexto arquitetônico e do uso do edifício, além de manter o respeito pelas obras de períodos diferentes em uma mesma edificação. Foi um dos colaboradores na elaboração da carta de Atenas 1931, onde expôs seus princípios.

A contribuição destes teóricos da linha arquitetônica foi também importante na estruturação do pensamento e de teorias relacionadas à conservação de obras de arte, apesar das características e da natureza constitutiva das obras serem diversas, alguns princípios se mantiveram os mesmos.

Questionamentos em relação à forma de se tratar as obras antigas já despontavam no Renascimento, pois o humanismo trouxe uma nova visão ao homem e os monumentos antigos adquiriram o respeito e tornaram-se elementos de estudo da arquitetura, arte e tecnologia. Surgiram, com isso, as coleções para estudo e as preocupações com a proteção dos monumentos.

As artes passaram a ter um novo conceito nesse período não mais relacionado ao seu caráter funcional e artesanal como na ldade Média, mas relacionado à sua dimensão estética, enaltecendo seu aspecto artístico.

As mudanças introduzidas no decorrer dos séculos com o novo conceito de arte e da história geraram novas relações e formas de apreciação da natureza não mais sob a ótica do valor universal, mas do valor relativo.

O desenvolvimento econômico, político e social, decorrente da introdução das novas idéias humanistas, das ciências, das novas tecnologias favoreceu o avanço de novas posturas em relação à arte e a arquitetura.

Intervenções já vinham sendo feitas nas obras antigas e o tratamento a elas conferido era, até então, o de recomposição das partes faltantes principalmente em relação às esculturas. Essa postura também passa a ser revista em função das 
questões introduzidas pela valorização da obra original, em contraposição as cópias e adições freqüentemente realizadas.

Em relação às pinturas murais, JUKILEHTO (2002) ressalta que surgem já no século XVII com Giovanni Pietro Bellori (1613-1696), como Comissário para a Conservação dos Monumentos Antigos em Roma, as primeiras manifestações contrárias às repinturas e alterações que eram realizadas nos interiores dos edifícios. Através de uma crítica e análise da obras, fundamentado em uma filosofia neoplatônica, Bellori acaba influenciando a academia francesa e entre outros Johann Joachim Winckelmann.

Ainda segundo o autor, o controle realizado sobre as obras de intervenção de Carlo Maratta (1625-1713) nos afrescos de Rafael no Vaticano, na Villa Farnesina ${ }^{9}$ e supervisionados por Bellori, destaca a intenção dele em manter o respeito à obra, embora, posteriormente novas intervenções tenham sido feitas fugindo a sua intenção anterior. Talvez tenha sido a primeira vez que o princípio de reversibilidade foi claramente exposto, referindo-se ao uso pelo restaurador de material diferente do original e possível de remoção da obra de pintura mural.

Posição semelhante teve Pietro Edwards (1744-1821) ao assumir responsabilidade pela preservação das obras públicas em Veneza, enfatizando que - material usado não poderia ser prejudicial à obra e que deveria haver a possibilidade de remoção.

No século XVIII, Johann Joachim Winckelmann (1717-1768) historiador da arte e arqueólogo buscou compreender a essência da obra de arte avaliando-a pelo seu ideal de beleza com base na lógica neoplatônica e na teoria de seu antecessor Bellori. A perfeição, segundo ele, estava simbolizada na arte da Antiguidade Grega, arte que no seu entendimento deveria ser preservada, reconhecendo, porém, que deveria haver um princípio de distinção entre o original e a adição e que a intenção artística deveria ser respeitada.

JUKILEHTO (2002) esclarece que os objetos foram identificados por ele com uso de métodos científicos para determinação do seu valor histórico e artístico. Portanto, no século XVIII, no campo da conservação o desenvolvimento das ciências

9 JUKILEHTO (2002) menciona que novas intervenções foram realizadas por Maratta, após a morte de Bellori, na Stanza della Segnatura, de Rafael no Vaticano, no Palazzo Farnese e na Villa Farnesina, sem o rigor antes empregado de respeito à obra exigido por Bellori. Outras informações sobre as intervenções de restauro na Villa Farnesina em 1693/1694 destacando a intervenção de Maratta podem também ser consultadas. Disponíveis em:<http://www.villafarnesina.it/restauri.html>. 
exaltou o uso do método científico, do conhecimento e da lógica no tratamento das obras.

No contexto da Revolução Francesa no século XVIII, quando uma série de obras foram removidas de seus locais exigindo uma reflexão sobre a conservação e a restauração surge Antoine-Chrysostome Quatremère de Quincy (1755-1849) arqueólogo e crítico de arte francês nomeado para a Intendência Geral das Artes e Monumentos públicos da França. Ele destacou a importância das obras de arte permanecerem em seus locais de origem, em seu contexto para que pudessem ser melhor compreendidas, assumindo uma posição totalmente contrária a de Alexandre Lenoir (1762-1839) responsável pela criação do Musée des Monuments Français, cujas obras do acervo foram removidas de monumentos franceses intactos somente com fins preventivos e pedagógicos, porém sem critérios históricos ou científicos.

É possível reconhecer que discussões sobre o tratamento das obras já existiam em diferentes lugares e que, aos poucos, foram sendo introduzidas questões, que no século $\mathrm{XX}$, se consolidariam com uma teoria.

Outra contribuição significativa neste campo foi a visão do austríaco Alois Riegl (1858-1905) que com uma ampla formação nas áreas jurídica, filosófica e de historia da arte, introduziu no início do século XX uma nova perspectiva em relação aos monumentos com sua obra "Der Moderne DenkmalKultus" escrita em 1903.

Em O culto moderno dos monumentos Riegl estabeleceu uma distinção entre as diferentes categorias de monumentos. O monumento intencional relacionado à memória e ao passado e o monumento histórico relacionado a não intencionalidade, mas ao valor adquirido pelo monumento com o passar do tempo.

O monumento intencional é, segundo ele, qualquer obra produzida pelo homem com funções de manter viva na consciência das futuras gerações determinadas idéias. O monumento histórico, ou de valor histórico é todo aquele que já foi e não é mais, é irreparável e, ao longo do tempo adquiriu um valor histórico. A diferenciação está fundamentada nos valores atribuídos aos respectivos monumentos. Riegl introduz uma visão pautada no caráter filosófico e social da percepção e da recepção dos valores diferentemente das outras abordagens de natureza prática e técnica.

A decisão e direção de qualquer procedimento de preservação eram para ele embasadas na percepção do valor artístico. 
É, portanto, de fundamental importância para a nossa tarefa que tenhamos totalmente esclarecido esta diferença na percepção de valor artístico, desde que ele influencia de forma decisiva a direção principal de toda preservação histórica. ${ }^{10}$ (RIEGL, 1996, p.70, tradução nossa).

O valor artístico era para ele relativo e não eterno e conseqüentemente cada período e obra tinha seu valor. Além disso, ele identificou e refletiu sobre questões específicas relacionadas aos limites de intervenções e a educação das pessoas como meio de compreensão dos valores do patrimônio e também em questões específicas sobre arte mural, assim destacadas:

Riegl identificou três categorias possíveis de tratamentos para a restauração de pinturas murais: radical, arte-histórica ou conservadora. A abordagem mais radical foi entendida como uma intervenção mínima, com o objetivo de manter 0 sentimento de uma velha e decadente pintura com seus defeitos; a abordagem arte histórica foi um compromisso de dar prioridade à conservação e proteção das pinturas originais como um testemunho do passado; e a abordagem conservadora deve insistir na complementação e reconstrução da imagem original, como esta deveria ser (uma abordagem "conservadora" foi assim entendida pelos restauradores da metade do século XIX na Inglaterra completamente oposta à definição de Ruskin). ${ }^{11}$ (JOKILEHTO, 2002, p. 218, tradução nossa).

Inumeras foram as contribuições de diferentes personagens nesse contexto da teoria da restauração sendo que na área arquitetônica os princípios estavam melhor definidos já no início do século XX.

É somente na década de 1930, porém, com a atuação dos historiadores e críticos de arte como Giulio Carlo Argan (1909-1992) e Cesare Brandi (1906-1988), frente ao Istituto Centrale per il Restauro (ICR), em Roma, por eles criado em 1939, e do qual Brandi foi diretor durante vinte anos (1939-1959), que as intervenções nas obras de arte passaram a ser mais debatidas e se buscou a elaboração de uma

\footnotetext{
10 "It is therefore of fundamental importance to our task that we fully clarify this difference in the perception of artistic value, since it influences the principal direction of all historic preservation in a decisive way." (RIEGL, 1996, p.70)

11 "Riegl identified three categories of possible treatments to the restoration of wall paintings: 'radical', 'art-historical', or 'conservative'. The most 'radical' approach was understood as a minimum intervention, aiming to keep the feeling of an old and decayed painting with its defects; the 'art historical' approach was a compromise, giving priority to conservation and protection of the original paintings as a testimony of the past; and the 'conservative' approach would insist on the completion and reconstruction of the original image it once used to be ('conservative' approach was thus understood as by the mid-nineteenth century restores in England completely opposite to Ruskin's definition)." (JOKILEHTO, 2002, p.218)
} 
metodologia de intervenção em obras de arte, objetos arqueológicos e pinturas murais, que fosse fundamentada em bases científicas e num processo crítico.

Passou-se a exigir do profissional atuante não apenas habilidades artísticas, mas, sobretudo, conhecimento técnico e histórico e um posicionamento crítico diante das situações apresentadas por cada obra de arte.

O fundamento desta metodologia é a "Teoria del Restauro", ou Teoria da Restauração, desenvolvida por Cesare Brandi e publicada em 1963, que é essencial para o entendimento dos conceitos de restauração. Além disso, ela tem sido adotada não somente na Itália, mas em vários outros países, como fundamento teórico, até os dias de hoje, apesar de críticas a ela realizadas.

Brandi estabelece uma diferenciação em relação ao tratamento a ser executado em uma obra, que é produto da atividade humana com características industriais e aquele a ser realizado em uma obra de arte. Na primeira objetiva-se a restituição da sua funcionalidade e na segunda esse aspecto não é o primordial.

A obra de arte é um produto singular da atividade humana, tanto no aspecto do fazer, quanto do reconhecimento que é feito dela todas as vezes que é esteticamente vivenciada, percebida por um indivíduo singular, como um produto da atividade humana. (BRANDI, 2004).

O conceito de restauração, como formulou Brandi, não está fundamentado nos procedimentos práticos de restauração, mas no conceito de obra de arte, no seu reconhecimento como tal. (BRANDI, 2004)

Ainda seguindo seu pensamento a obra de arte é constituída pela imagem (aspecto) e pela matéria (estrutura). A matéria considerada como a consistência física e que na realidade representa, segundo ele, o tempo e o lugar da intervenção do restauro e a imagem representado a sua instância estética, seu o valor artístico e, sua instância histórica, de execução em determinado tempo e lugar.

É o 'juízo de artisticidade', mencionado por Brandi (2004), o caráter artístico, que determinará o reconhecimento da obra de arte, a sua singularidade e os condicionantes da restauração e de sua qualidade, enfatizando assim, a ligação intrínseca da obra de arte com a restauração.

Também será considerada a matéria enquanto suporte da obra de arte e a dupla polaridade estética e histórica que a obra traz a consciência e a recepção pelo indivíduo. 
Brandi define a restauração:

A restauração constitui o momento metodológico do reconhecimento da obra de arte, na sua consistência física e na sua dúplice polaridade estética e histórica, com vistas a sua transmissão para o futuro. (BRANDI, 2004, p. 30)

O momento metodológico do reconhecimento da obra como obra de arte implica no processo de reconhecimento da obra em seu caráter artístico, estético, na sua singularidade, bem como em seus aspectos materiais e na sua história por um indivíduo.

O restauro é, segundo Brandi, uma atividade crítica, pois a intervenção prática deve estar embasada pelos princípios teóricos e cada obra apresenta uma realidade distinta que exige considerações particulares, portanto um juízo crítico.

O Juízo Crítico é definido por ele como uma interpretação crítica da obra de arte e deve ser alicerçado na história e na filosofia para evitar que ações arbitrárias individuais sejam capazes de destruir a mesma em todos seus aspectos.

A restauração na sua atuação prática está relacionada com a consistência física da obra. Um dos princípios é que se restaura somente a matéria, que é o que assegura a transmissão da imagem e a recepção pelo indivíduo.

A Teoria estabelece que os limites da restauração são definidos pelo conceito de unidade da obra de arte. Portanto, é a unidade potencial da obra de arte que deve ser restabelecida no ato da restauração, sem que sejam eliminados os vestígios do tempo na obra e sem que seja falseada a sua apresentação estética.

Brandi resolveu o problema da recuperação da integridade estética da obra ao criar o método de reintegração de lacuna, que permitiria uma racionalidade e evitaria um falso histórico na obra, respeitando a integridade daquilo que chegou ao momento presente.

Os princípios da Gestalt foram por ele utilizados na compreensão do modo de percepção visual, de como a forma é percebida pelo indivíduo. Apesar de ser considerado como singular este processo de percepção segue a lógica de uma organização cerebral que é espontânea e não arbitrária. Portanto, através de um método regido por esses princípios extrai-se a arbitrariedade da percepção visual de uma obra.

Através da Gestalt ele busca a solução para a questão da lacuna, que pode ser interpretada no campo da percepção como a figura e a imagem como o fundo. $O$ 
conflito é causado quando a lacuna funciona como fundo e a imagem como lacuna, daí a necessidade de se neutralizar a lacuna.

O método criado para trabalhar a questão da lacuna destaca o princípio da distinguibilidade das intervenções e da reversibilidade, com a intervenção feita de tal forma que se permita realizar futuras intervenções.

[...] Dado que o juízo crítico só pode ser individual, a integração proposta deverá, então, contentar-se com limites e modalidades tais de modo a ser reconhecível à primeira vista, sem documentações especiais, mas precisamente como uma proposta que se sujeita ao juízo crítico de outros. Por isso qualquer eventual integração, mesmo se mínima, deverá ser identificável de modo fácil: e foi assim que elaboramos, no Instituto Central de Restauro, para as pinturas, a técnica do tratteggio com aquarela que se diferencia por técnica e por matéria, da técnica e da matéria da pintura integral. (BRANDI, 2004, p. 126)

Além disso, os limites da intervenção devem ser determinados pela indicação fornecida pela própria lacuna e, o material original da obra não deve ser substituído se contribui diretamente para o aspecto figurativo, mas somente quando necessário e se relacionado ao aspecto estrutural. Portanto, a mínima intervenção deve prevalecer.

O estabelecimento da Teoria da Restauração a definição do conceito de restauração, seus princípios de distinguibilidade, reversibilidade e mínima intervenção, permitiram que o empirismo de ações de restauração e a subjetividade (arbitrariedade) de seus executores fossem gradativamente sendo substituídos pela objetividade, pelo método e pelo conhecimento científico.

A Teoria da Restauração de Brandi também abordou aspectos relacionados à 'restauração preventiva', conceito que ele define como sendo diverso do conceito de 'restauração'. Brandi introduz a reflexão sobre a importância da relação da obra com o espaço ou ambiente que a contém.

Como restauração preventiva entenda-se predispor as condições mais adequadas para a conservação, a visibilidade e a transmissão da obra para 0 futuro; mas também como salvaguarda das exigências figurativas que a espacialidade da obra produz no que concerne à sua ambientação.(BRANDI, 2004, p. 218)

A 'restauração preventiva', segundo ele, enfoca o ambiente que envolve a obra e o desenvolvimento de ações que permitam a manutenção de um equilíbrio 
entre a obra e o ambiente, ações indiretas, diferentemente da 'restauração que é a intervenção propriamente dita na obra, as ações diretas.

Durante vários anos a Teoria da Restauração de Brandi norteou as intervenções de restauração principalmente das obras de arte, não só na Itália onde surgiu, mas em diversos países por onde foi propagada de forma mais ou menos intensa.

Ao avaliar o impacto da obra de Cesare Brandi no contexto internacional JOKILEHTO (2002) ressalta que a obra de Paolo Mora, Laura Mora e Paul Philippot $^{12}$, Conservation of Mural Paintings, apresenta uma conexão com a obra de Brandi já que os conceitos propostos por ele foram desenvolvidos e aplicados nos locais necessários, permitindo a avaliação de resultados com a participação do próprio Brandi.

Os autores Paolo e Laura Mora e Paul Philippot reafirmam, portanto, a Teoria de Brandi, mas com uma metodologia aplicada à área de pintura mural. A obra Conservation of Mural Paintings, amplamente difundida e reconhecida como referência na conservação e restauração de pinturas murais ainda hoje, reflete o pensamento dos autores, que consideram o juízo crítico como precedente,,elucidador e determinador do valor e significado da obra e da finalidade da sua preservação, bem como da extensão ou abrangência dos procedimentos técnicos a serem aplicados.

Uma obra só é preservada em função de seus valores e do significado cultural que ela representa no seu respectivo contexto. São eles que justificam a sua necessidade de preservação e, o não reconhecimento destes valores implica em uma possível perda da obra. Por isso, é necessário conhecer a obra e fundamentar o conhecimento num método.

Na operação técnica de restauração, a intervenção é determinada pelo objetivo e pela finalidade que se pretende atingir com a preservação, variando, portanto de acordo com a obra em questão.

A reunião desses conceitos e princípios, dos termos técnicos específicos da área, norteadores das intervenções de restauração em obras de arte e especificamente em obras murais, destacados pela Teoria da Restauração de Brandi

12 O casal Paolo Mora e Laura Sobordoni Mora foram chefes dos restauradores do Istituto Centrale per il Restauro e Paul Philippot estudou no Instituto com Cesare Brandi e foi posteriormente diretor do ICCROM (1971-1977). 
e enaltecidos pela obra de Mora e Philippot, permite considerar que as bases empíricas e as práticas artesanais, foram sendo gradativamente substituídas por fundamentos teóricos e científicos aplicados a área de conservação na Europa.

A princípio são determinados os valores e significados da obra em seu contexto e sua necessidade de preservação e, conseqüentemente, aplicados os princípios da Teoria estabelecendo a metodologia para a atuação na área de murais, principalmente no que concerne a limpeza e a apresentação estética de lacunas, aspectos que exigem não apenas a habilidade técnica, mas principalmente um juízo crítico.

Apesar das inúmeras diferenças das obras murais com relação a seus aspectos técnicos e estéticos em seus respectivos contextos, pode-se dizer que os princípios introduzidos por Brandi, no contexto italiano e trabalhados de modo aplicado em sua grande maioria sobre obras constituídas na técnica de afresco, permanecem válidos de modo geral para uma gama maior de materiais usados na arte mural, realizando as devidas adaptações.

Todavia, cabe ressaltar que os princípios passaram a ser revistos e criticados nos anos 1960 e 1970 em função do aumento de obras, consideradas como patrimônio cultural. A ampliação da noção de patrimônio, no século $X X$, acarretou 0 acréscimo de uma série de objetos a serem preservados e cujos critérios de conservação de obra de arte segundo alguns autores não mais se aplicavam a eles e, portanto, novas necessidades surgiram.

JOKILEHTO (2002) confirma que a teoria foi passível de críticas que questionavam a sua aplicação em objetos de pouca ou nenhuma significância estética, pois ela evidenciava a questão da imagem, estética em detrimento da estrutura como um todo.

Essas críticas têm sido rebatidas por estudiosos da área que, dentro de seus respectivos campos de atuação, ${ }^{13}$ têm procurado trabalhar a Teoria da Restauração de Brandi através da ampliação dos conceitos e metodologia para aplicação em diferentes manifestações culturais, como menciona KUHL (2007). A autora ainda acrescenta que, a presença de diferentes posturas e correntes, até mesmo

\footnotetext{
${ }^{13}$ Beatriz Kuhl (2007) menciona os esforços de aplicação do conceito e do método da teoria de Brandi por alguns autores em manifestações como: no cinema por Michele Cordaro, na arte contemporânea por Heinz Althoeffer, na questão urbana trabalhada por Giovanni Urbani, nos diferentes tipos de obras trabalhadas pelo ICR, incluindo a arte mural, por Giuseppe Basile seu diretor, na arquitetura por Giovanni Carbonara.
} 
divergentes, não representa a superação da Teoria de Brandi, mas sim uma discordância. ${ }^{14}$

Brandi reconhece a arquitetura também como expressão artística e não separa os princípios como sendo diferentes para arquitetura ou para objetos de arte, portanto, a única coisa que eventualmente se estabelece como diferente é a atuação prática em uma obra ou em outra em função das características e das questões levantadas pela própria obra. A atuação prática, ou seja, os procedimentos realizados para a aplicação dos princípios dependem e devem ser embasados no juízo crítico.

A partir da década de 1960, ocorreram algumas mudanças com relação aos procedimentos executados nas obras, como uma redução significativa na série de obras murais que foram removidas de seus locais de origem para preservação, uma prática que era comum anteriormente. Alguns procedimentos foram também revistos em relação às remoções principalmente por causa do reconhecimento da necessidade da apreciação da obra não como objeto isolado, mas inserida no seu contexto:

Desde os anos de 1960 a prática da conservação tem defendido a preservação no local de pinturas murais, rebocos e mosaicos a fim de manter tanto a integridade do conjunto arquitetônico quanto do contexto da superfície. $\mathrm{Na}$ prática corrente a remoção de pintura mural e mosaicos é comumente considerada a ultima opção quando não se tem alternativa para a preservação no local. Isto tem criado desafios para a sua preservação física e a manutenção de extensas superfícies e sua interpretação, por causa de inúmeros fatores incluindo condições ambientais estruturais e de gerenciamento de sitio. ${ }^{15}$ (RAINER, 2010, p. 06, tradução nossa)

Apesar de certas discordâncias e dificuldades encontradas por restauradores em por em prática os princípios enunciados na teoria, muitos dos quais acabam recebendo ajustes ${ }^{16}$ e se tornando mais flexíveis em função dos problemas

\footnotetext{
${ }^{14}$ Para conhecimento da influência da Teoria de Cesare Brandi em diversos países ver publicação intitulada II pensiero do Cesare Brandi dalla teoria alla pratica, em 2007 que reúne os trabalhos apresentados no evento comemorativo do centenário de nascimento de Cesare Brandi.

15 "Since the 1960s, conservation practice has advocated for the in situ preservation of wall paintings, plasters, and mosaics in order to retain both the integrity of the architectural ensemble and the context of the surface. In current practice, detachment of wall paintings and mosaics is commonly considered to be the very last resort when there is no alternative for their conservation in situ. This has created challenges to the physical preservation and maintenance of the extant surfaces and their interpretation, because of a number of factors, including environmental conditions, structural issues, and site management." (RAINER, 2010, p. 06)

${ }^{16}$ Barbara Appelbaum em seu artigo "Criteria for treatment: reversibility" publicado no Journal of the American Institute for Conservation (JAIC), em 1987, faz uma revisão do princípio da reversibilidade
} 
evidenciados nas respectivas obras, é possível se dizer que eles ainda servem de referencial teórico-metodológico das ações de restauração.

Todavia, neste século XXI, surgem posturas já contrárias a teoria e a exemplo disso temos a crítica de Salvador Munoz Viñas ${ }^{17}$, que levanta várias questões relativas à pertinência da Teoria de Brandi nos dias de hoje, destacando que a época em que ela foi criada, o contexto e as exigências eram outras.

A obra escrita por VIÑAS, em 2003, com versão em inglês Contemporary Theory of Conservation de 2005, é reflexo de questionamentos surgidos na tentativa da aplicabilidade prática, dos princípios de distinguibilidade, reversibilidade, mínima intervenção da clássica Teoria da Restauração de Brandi.

Viñas (2008) em sua argumentação sobre a pertinência da Teoria da Restauração analisa a própria definição do termo restauração dada por Brandi, esclarecendo que da forma com foi exposto por ele, deixa a responsabilidade pelo reconhecimento da obra de arte ao historiador e/ou crítico de arte, reduzindo o restaurador a um mero operador das decisões de outros. Este argumento é embasado na idéia de que na época de Brandi, que era historiador e crítico de arte, não existiam escolas de restauração sendo fundado o ICR em 1939 para esta finalidade e a presença de um historiador da arte era fundamental, já que a prática da restauração era exercida por artesãos e artistas.

$\mathrm{Na}$ atualidade, como menciona o autor, a formação do profissional de restauração em nível superior se alterou e vem se alterando, abrangendo várias áreas e, portanto, é perfeitamente possível com sua capacitação estabelecer um dialogo sobre questões estéticas com outros colaboradores da área.

No entanto, este argumento de Viñas torna-se improcedente quando se evidencia que a posição do restaurador não era de mero executor, mas de um profissional ativo dentro de uma equipe composta por diferentes profissionais, que estabeleciam relações de colaboração entre as diversas competências multidisciplinaridades e, cuja atuação conjunta fundamentava as decisões sobre os procedimentos a serem executados, com bases em um método e em exames

aplicado a determinados tipos de obras, ele deve estar associado não ao uso do material como reversível, mas ao processo de intervenção como reversível, adotando, portanto, o uso do termo retratabilidade que, segundo ela se ajusta melhor.

${ }^{17}$ Salvador Munoz Viñas é artista, historiador da arte trabalhou com conservação e restauro de papel e é Professor (Catedrático) desde 2000, em teoria da conservação e técnicas de conservação de papel na Universidade Politécnica de Valência. 
científicos, seguindo a metodologia de trabalho inovadora desenvolvida no ICR e implantada por Brandi, que foi seu fundador e diretor. A proposta de estruturação do ICR estava embasada no modelo desenvolvido no documento Progettata istituzione di um Gabinetto Centrale del Restauro. ${ }^{18}$

A crítica a Teoria passa ainda pela questão da aplicabilidade da instância estética, primordial para Brandi, mas que, segundo o autor, na atualidade somente é aplicável para alguns tipos de objetos que devem ser preservados e não para todos, principalmente para aqueles cujo valor é essencialmente histórico ela apresenta certos problemas.

A conservação na atualidade deve se concentrar não em objetos de arte históricos ou antigos, mas segundo VIÑAS (2005), naqueles objetos que são representativos de uma simbologia ou evidências de disciplinas etno-históricas. $O$ significado do objeto, mais do que a sua autenticidade material deve ser preservado.

A questão da autenticidade, segundo o autor, não é primordial diferentemente das teorias clássicas em que existe um esforço grande por revelar a verdade natural do objeto ou a sua integridade, expressa na crença da preservação da materialidade do objeto baseada na utilização de um método científico. Para o autor significativo é:

\begin{abstract}
Basicamente, quando falamos sobre um objeto 'autêntico' ou sobre um 'autêntico' estado de um objeto, nós na realidade estamos nos referindo a um estado esperado ou preferencial do objeto. Conservadores, muitas vezes, alteram ou excluem as marcas autenticas da história, por uma questão de 'autenticidade'; o problema com essas marcas (uma superfície desgastada, uma ausência de fragmento, um verniz escuro), não é que eles não são autênticos, mas que não gostamos deles. Nós preferimos o objeto em um estado diferente. Conservadores assim modificam a realidade (que é, sem dúvida, autêntica) para atender às nossas expectativas, necessidades ou preferências. Assim autenticidade é útil porque ajuda a acreditar que estamos agindo para algumas razões maiores (verdade, ciência, objetividade, etc.) e não que nós simplesmente estamos implementando nossas próprias expectativas ou preferências. ${ }^{19}$ (VIÑAS, 2008, p. 22, tradução nossa)
\end{abstract}

${ }^{18}$ Progettata istituzione di um Gabinetto Centrale del Restauro é o documento proposto por Giulio Carlo Argan em 1938 que contém as bases estruturadoras do modelo inovador de criação de uma escola e centro de diagnóstico e é descrito por Mario Micheli em seu artigo II modello organizzativo dell'Istituto Centrale del Restauro e Le Conseguenze sul piano Metodologico In: ANDALORO, 2006, p. 167. O modelo proposto por Giulio Carlo Argan destaca a criação de uma equipe multidisciplinar.

19 'Basically, when we speak about an 'authentic' object, or about then 'authentic' state of an object, we actually referring to expected or preferred state of the object. Conservators often alter or deleted the authentic imprints of history, for the sake of 'authenticity'; the problems with those imprints (a marred surface, a missing fragment a darkened varnish, you named it) is not that they are not authentic, but that we don't like them. We prefer the object to exist in a different state. Conservators thus modify reality (which is undoubtedly authentic) to suit our expectations, needs or preferences. So authenticity is useful because it help us to believe that we are acting form some higher reasons (truth, science, objectivity, etc.) and not that we are simply implementing our own expectations or 
Na sua compreensão, é o significado, a simbologia do objeto que é o que deve prevalecer. A verdade depende daquilo que a pessoa acredita que o objeto é ou pode ser, a verdade não está no objeto, mas na forma como nós entendemos e vemos o objeto.

A ciência é para ele um instrumento que fornece informações e dados, mas não substitui a ética, não pode guiar a conservação e as decisões não devem ser tomadas com base na ciência, mas pelas necessidades e pelas expectativas das pessoas.

Lembramos que a análise de Viñas sobre a Teoria de Brandi abrange os vários tipos de objetos a serem preservados, mas ele não menciona nada específico sobre arte mural, embora ela possa estar inserida dentre esses objetos.

Cabe aqui também salientar que, apesar do aparecimento desta 'nova teoria' ou 'reflexão teórica', ela também estaria, de certa forma condicionada ao ambiente, ou a uma realidade diferente da nossa, que é aquela do continente Europeu.

VIÑAS critica a exaltação da materialidade e da ciência como fontes de determinação da autenticidade do objeto. Crítica perfeitamente compatível com o continente europeu, cujo histórico da conservação apresenta posturas mais enfáticas em relação ao uso da ciência na aplicação de procedimentos de restauração, diferindo da nossa realidade.

Apesar de considerar a validade de algumas de suas colocações no que tange a aplicabilidade de alguns princípios da teoria, deve-se reconhecer que o contexto brasileiro e especificamente o paulista é diverso do da prática européia, pois ainda se encontra na fase de início do envolvimento da ciência como instrumento para auxiliar a prática da restauração como veremos mais adiante ao longo dos capítulos.

$\mathrm{Na}$ nossa realidade, pelo fato da ciência estar, ainda, sendo inserida nesses trabalhos acreditamos que a sua função é de servir de fundamentação e criar subsídios para uma prática mais consciente e com um melhor embasamento de conhecimento científico. A materialidade é um componente essencial diante dos inúmeros exemplos de intervenções invasivas e muitas vezes sem escrúpulos ou critérios que se destacam de forma geral na área de conservação e restauro. No

preferences." (VINÃS, 2008, p. 22) Entrevista com Salvador Muñoz Viñas para Christabel Blackman restauradora de pintura e publicada na revista e-conservation com o título de New Horizons for Conservation Thinking. 
entanto, outros valores também devem estar também inclusos ao se considerar a autenticidade do bem.

Essa colocação crítica de Viñas, não deve induzir ao pensamento de que a ciência seja sempre a causadora ou determinadora de posturas que possam comprometer a "autenticidade da obra", mas sim de que eventuais questões de atitudes mais extremas já foram vivenciadas no continente europeu.

Apesar das críticas feitas à pertinência da Teoria de Brandi e, o desenvolvimento da chamada 'teoria contemporânea da restauração' verifica-se que a formação de alguns profissionais atuantes no nosso contexto, ocorreu no exterior e tem seguido a linha italiana, portanto, a 'Escola de Brandi'.

Em uma reflexão sobre a situação da restauração na América KUHL (2007) afirma que as questões relacionadas à intervenção de restauração em um bem cultural, sua modalidade bem como seus critérios não são definidos pela lei.

O campo dos princípios teóricos da restauração, que devem embasar as intervenções práticas é, todavia, pouco explorado: atualmente não existe uma reflexão aprofundada relacionada à realidade cultural do país. ${ }^{20}$ (KUHL, 2007, p. 138 tradução nossa).

Isso implica na adoção de uma diversidade de procedimentos em relação às intervenções arquitetônicas, que não correspondem exatamente a uma interpretação precisa da Carta de Veneza adotada como referência e critério para os projetos de conservação e restauração a partir dos anos 1960.

Apesar da prática de conservação da arte mural estar embasada nos conceitos teóricos fundamentados na Teoria de Brandi com seus princípios de: distinguibilidade, reversibilidade (ou retratabilidade) ${ }^{21}$ e mínima intervenção, manifestações mais recentes da arte mural e sua conseqüente conservação tem trazido novas questões para reflexão sobre a Teoria clássica de Brandi.

As reflexões surgem da necessidade da restauração de murais comunitários em Los Angeles, cujos questionamentos refletem o aparecimento de outras posturas

\footnotetext{
20 "Il campo dei princípi teoretici del restauro, che dovrebbero supportare gli interventi pratici, tuttavia, é poco esplorato: attualmente non esiste una riflessione approfondita rivolta alla realtà culturale del paese." KUHL (2007,p. 138).

${ }^{21}$ A retratabilidade é o termo usado atualmente por vários profissionais da área de conservação e restauro em substituição ao termo reversibilidade que tem revelado ser muitas vezes um processo difícil de ocorrer em função do tipo de intervenção realizada e do material usado, não totalmente reversível. O termo retratabilidade designa a possibilidade de realização de um novo tratamento de intervenção na obra no futuro.
} 
em relação à preservação desses tipos de murais. ${ }^{22}$ Essas reflexões talvez se aproximem das idéias de VINÃS no que concerne a autenticidade, exaltando não o caráter material da obra, mas o seu valor e representatividade para a comunidade.

Todavia, elas representam manifestações pontuais e específicas no contexto geral da preservação desse tipo de arte e que ainda não foram tão difundidas.

Em relação à arte mural, no entanto, ainda permanece e prevalece a Teoria de Brandi, base da obra de Paolo e Laura Mora e Paul Philippot, como sendo a norteadora das intervenções de restauração de pintura mural, tanto no exterior como aqui por aqueles que tiveram uma formação na área de conservação e restauro.

\subsection{A Arte Mural como Bem Integrado.}

Grande parte das obras de arte apresentam estilo, temática e iconografias próprias, muitas delas também se destinam a locais específicos em edifícios ou em ambientes menores, como ocorre com as obras murais

Desde tempos mais remotos a obra mural fez parte da composição dos edifícios sendo inserida no espaço da edificação com finalidades distintas que variavam do registro dos fatos históricos, da expressão de poder e hierarquia social, da simbologia, da espiritualidade humana ou mesmo da decoração.

Portanto, o local onde a obra é inserida ou seu entorno, sempre desempenha um papel importante na compreensão do seu significado, de seu valor cultural, ao mesmo tempo em que influi consideravelmente na sua preservação do ponto de vista material.

Sempre que o estado de conservação, os perigos ameaçadores, e as
possibilidades de preservação das pinturas murais são debatidas, grande
atenção é dada as camadas de pintura e de reboco, mas muitas vezes as
paredes que as suportam não são adequadamente consideradas. Na realidade a
vida de qualquer pintura mural depende criticamente do estado da parede, e

${ }^{22}$ Novas posturas em relação à preservação de murais comunitários são destacadas por profissionais envolvidos na conservação de murais em Los Angeles. A publicação Newsletter de 2003 do Getty Conservation Institute reune discussões de alguns autores como Jon Pounds, Timothy Drescher e Will Shank, sobre a preservação de murais em Chicago considerado o berço do movimento comunitário mural. 
neste contexto os aspectos mais decisivos são acidez, umidade e estabilidade estrutural. ${ }^{23}$ (ARENDT, 1987, p. 29, tradução nossa)

A inserção das artes, pintura, escultura, talha e murais em edifícios oficiais, civis e religiosos foi característica marcante da nossa arquitetura nos diversos períodos, assim também como em outras civilizações.

No período colonial a arte mural se destacou aqui pelo uso de azulejos, em edificações religiosas do século XVII e XVIII no litoral, desde a região norte e nordeste, até o sudeste, concentrando-se principalmente na Bahia, Pernambuco, Paraíba e Rio de Janeiro, com obras de representações de cunho religioso, moral e profano, geralmente composta de azulejos trazidos de Portugal.

BURY (2006) relata que a azulejaria se concentrou, portanto, em parte do território nacional, principalmente na faixa litorânea e o seu uso também se propagou para as edificações civis ornamentando residências na fachada ou no interior, com a aplicação de azulejos que representavam cenas de caça, pastoris e mitológicas, com faixas de molduras trabalhadas.

A execução deste tipo de arte estava diretamente relacionada com as necessidades e benefícios gerados pelas riquezas advindas dos diferentes ciclos econômicos.

No século XIX houve a introdução de uma arte decorativa de inspiração clássica nas edificações oficiais, resultado de um novo gosto estético mais condizente com a nova realidade da época, marcada pela presença da família real no Brasil desde 1808 e pela influência da Missão Artística Francesa vinda para o Rio de Janeiro, em 1816, com o incentivo de Dom João VI.

A fundação da Academia Imperial de Belas Artes permitiu a propagação do ensino artístico acadêmico e o desenvolvimento de uma arquitetura oficial de estilo neoclássico, cujas obras passaram a apresentar em seus interiores paredes com divisões em molduras e arremates e pinturas decorativas e artísticas de motivos clássicos.

A arte mural também se difundiu para as edificações civis pertencentes à classe aristocrática dominante em fins do século XIX início do XX. Esse tipo de arte

\footnotetext{
${ }^{23}$ "Whenever wall paintings, their state of preservation, the dangers menacing them, and the possibilities of conserving them are discussed, keen attention is paid to paint and plaster layers but often the walls supporting them are not adequately considered. In reality the life of any wall painting depends critically on the status of the wall, and in this context the most decisive aspects are structural stability, moisture, and acidity." (ARENDT, 1987, p. 29)
} 
se concentrou no RJ e em SP, nas residências rurais sede das fazendas de café do Vale do Paraíba e a oeste do interior de São Paulo, além de estarem presentes nas residências desses mesmos proprietários já na área urbana.

$\mathrm{Na}$ cidade de São Paulo a arte se intensificou com o desenvolvimento urbano crescente proporcionado pelas riquezas das exportações do café, que permitiu a importação de materiais e tecnologia estrangeira, bem como da mão de obra do imigrante que teve papel importante na construção, na expansão arquitetônica e na difusão das técnicas artesanais e da arte mural.

A arquitetura neoclássica e eclética manteve ainda a produção desse tipo de arte nos seus mais variados estilos e motivos ornamentais e artísticos. Arte essa, que foi sofrendo alterações somente com o aparecimento da arquitetura moderna.

A arquitetura moderna introduziu como necessidade à vida do homem, uma arquitetura funcional, com simplicidade de formas, praticidade que refletia o despojamento do ornamento, a supressão de todo e qualquer excesso de ornamentação, característico do outros estilos arquitetônicos.

A arte mural adquiriu, então, na arquitetura moderna um novo significado. A presença das artes na arquitetura, espelhou as idéias inovadoras trazidas por Le Corbusier, para o nosso contexto, por ocasião de sua visita ao Brasil difundidas por Gregori Warchavchik em SP, cujo manifesto de 1925 já se inspirava em argumentos do autor e, por Lucio Costa no RJ na década de 1930 como destaca BRUAND (1997).

Idéias que foram trabalhadas de forma criativa pelos jovens arquitetos cariocas com liderança de Lucio Costa, como Oscar Niemeyer, Affonso Eduardo Reidy, Ernani Vasconcellos, entre outros, que exerceram a prática arquitetônica na década de 1930.

A arte mural executada nesse período e introduzida na cidade do Rio de Janeiro na arquitetura oficial, representada pela sede do Ministério da Educação e Saúde, marca também a volta do azulejo como elemento integrante do projeto modernista. O mural artístico é introduzido na arquitetura como um elemento de humanização do espaço junto com a arte da escultura e pintura. 


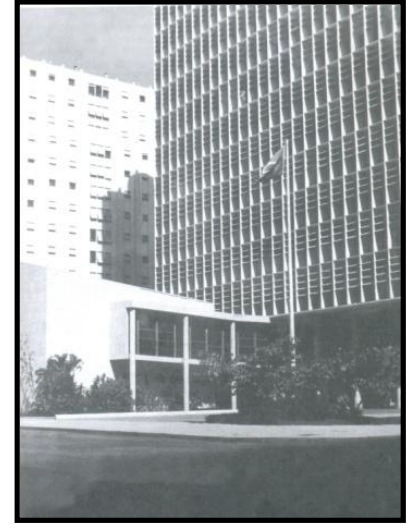

Figura 1 - Ministério da Educação e Saúde Fonte: CAVALCANTI, Lauro, 2006

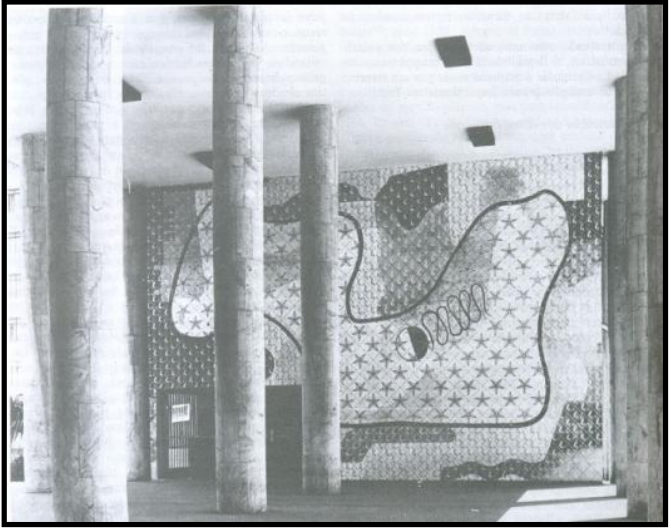

Figura 2- Detalhe de mural de azulejo Fonte: BRUAND, Yves, 2008

A valorização de elementos construtivos, materiais, formas e espécies naturais locais, representava aspectos de inovação da arquitetura que atendiam às novas expectativas e princípios condizentes com a realidade urbana em transformação.

Em São Paulo a nova arquitetura também se difundiu principalmente porque houve uma maior concentração de arquitetos e artistas atuantes na área, incentivados pelo crescimento urbano da cidade.

Muitas das obras realizadas na cidade de São Paulo entre 1930-1960, se encontram em casas e edifícios residenciais e comerciais projetados por arquitetos de considerável renome como Adolf Franz Heep, Roberto José Goulart Tibau, Oswaldo Correa Gonçalves, Abelardo R. de Souza, Miguel Forte, etc, cuja contribuição ao desenvolvimento arquitetônico da cidade foi bastante significativa como representantes da nova arquitetura que despontava.

O movimento moderno na arquitetura é identificado pelos vários princípios introduzidos por Le Corbusier, que buscavam atender a necessidades de ordem econômica, social e técnica e pela integração das artes e da arquitetura. Integração essa conseguida através da concepção conjunta do mural com a arquitetura, da temática adotada pela obra, das suas dimensões, da implantação no espaço arquitetônico ou dos materiais utilizados. ${ }^{24}$

A inserção de novos materiais na arquitetura dentre os quais materiais de revestimento arquitetônico como as pastilhas, azulejos, cerâmicas, etc contribuíram

\footnotetext{
${ }^{24}$ A integração das artes e da arquitetura é um tema abordado por autores como: LEGÉR (1989); CORBUSIER (1984), COSTA (1980) e debatido por AMARAL (1983), LOURENÇO (1995), etc.
} 
para o desenvolvimento de uma nova estética e expressão plástica dos artistas atuantes na área.

A arte mural, atualmente, vem ainda se apresentando como manifestação artística na obra arquitetônica, embora de forma mais reduzida e sem uma linguagem própria que possa definir um período, estilo ou temática característica. Geralmente é realizada em espaços públicos e privados, como escolas, estações de metrô, edifícios comerciais, etc.

Presentes ainda em várias edificações na cidade de São Paulo essas obras murais devem ser objetos de uma reflexão mais profunda e do desenvolvimento de estudos do tipo de produção artística inserida na edificação, dos objetivos, da iconografia e do histórico da obra (inclusive de intervenções), complementarmente aos estudos arquitetônicos em várias delas já realizados. Essa arte ocupa um lugar na obra arquitetônica, que varia em função do espaço arquitetônico, exigindo também, um tratamento específico por apresentar certas peculiaridades, principalmente quando se refere à execução de trabalhos de conservação e restauração.

As soluções para as questões de conservação são introduzidas pelas necessidades da própria obra, sendo, portanto, pontuais e também particulares 0 que restringe e inviabiliza a aplicação de soluções genéricas.

Todavia, os conceitos e a metodologia de trabalho podem e devem ser seguidos dentro de determinados padrões para se evitar quaisquer equívocos, arbítrio ou surpresas indesejáveis. A sua intervenção deve ser executada com o devido conhecimento teórico que envolve a história, a estética, a materialidade e a técnica que uma obra de arte exige e o seu tratamento deve ser diferenciado daquele dado a uma parede que é simplesmente pintada, ou trabalhada com cor ou forma diferente na edificação.

O reconhecimento da arte mural como bem integrado acarreta a necessidade de se combinar aspectos de preservação arquitetônica e da preservação da obra de arte. A integração e articulação destas duas áreas é o requisito básico para o sucesso de qualquer intervenção. Portanto, considerações sobre metodologia de intervenção em obra arquitetônica e em obras de arte neste caso devem caminhar juntas. 
$\mathrm{Na}$ realidade no contexto internacional estas discussões já avançaram bastante inclusive na estruturação de uma atuação, seguindo a Teoria de Cesare Brandi e também os princípios enunciados pelas cartas patrimoniais, cuja mais citada é a Carta de Veneza, promulgada em 1964, que é o resultado da abordagem e da evolução de conceitos teóricos introduzidos no início do século $X X$ e reafirmados por esse documento, alguns dos quais fundamentados na Teoria de Brandi já citada.

Não temos no contexto brasileiro nenhuma teoria própria ou princípios específicos estabelecidos como parâmetros para a orientação dos trabalhos de intervenção nesse tipo de arte. $O$ restrito grupo de profissionais atuantes e que tiveram uma formação na área seguem também os princípios da Teoria da Restauração de Cesare Brandi, porém representam uma parcela mínima nesta situação de atuação prática tão abrangente.

\subsection{Cartas e Documentos Internacionais e Nacionais:}

As cartas e documentos internacionais, posteriores as vertentes teóricas da restauração que se desenvolveram em fins do século XIX e início do século XX, enunciam os princípios, recomendações e orientações que fundamentam a preservação dos bens culturais. Apesar de serem indicativos de ações de preservação, não constituem uma teoria em si.

As cartas e documentos internacionais têm sido utilizados, no exercício da prática da conservação e restauração de bens culturais como referências e citados em projetos como justificativas, embasando a escolha por determinados procedimentos técnicos e por opções de materiais.

Nos documentos internacionais quando feita alguma menção à preservação de um bem integrado, principalmente de murais a terminologia utilizada é, geralmente, a da pintura mural em função da sua existência milenar, diferentemente das outras técnicas introduzidas no século $X I X$ ou no século $X X$ com o desenvolvimento da arquitetura moderna, que utilizam outros tipos de materiais na execução da obra mural, mais próximos de uma linha de materiais industriais de revestimento. 
Portanto, no tratamento do tema e em grande parte da bibliografia técnica e científica produzida encontraremos o termo pintura mural, considerando, todavia os diferentes suportes e as especificidades de suas técnicas ${ }^{25}$ (afresco, têmpera, etc).

No que tange a arte mural, que é um bem integrado, além das tradicionais cartas relacionadas à preservação da área arquitetônica ${ }^{26}$, devem ser considerados os outros documentos que de forma direta ou indireta estão relacionados à sua preservação. As cartas e documentos tiveram um papel importante na sua preservação, apesar de não terem uma abordagem tão específica e detalhada com relação ao tema. Isso somente se alterou com o desenvolvimento da Teoria da Restauração de Cesare Brandi quando menções específicas foram feitas sobre a área.

A carta de Atenas de 1931, resultado de uma reunião do Escritório Internacional de Museus da Sociedade das Nações representou uma ampliação do movimento internacional em prol da preservação de monumentos e o incentivo culminou com o aparecimento de instituições voltadas à preservação como $\mathrm{ICOM}^{27}$ (1946) e a UNESCO (1945/1946) e, posteriormente, do ICCROM (1956/1959), definindo os princípios básicos da conservação e restauração dos monumentos históricos e estabelecendo tópicos que seriam posteriormente mais trabalhados na Carta de Veneza.

Em 1964, com a Carta de Veneza, documento produzido no II Congresso Internacional de Arquitetos e Técnicos de Monumentos Históricos realizado de 25 a 31 de maio, introduziram-se os princípios gerais para a conservação e restauração cuja finalidade era a da salvaguarda do patrimônio cultural. O patrimônio passou a englobar além dos monumentos, as obras arquitetônicas singulares e as obras de arte, tudo o que era representativo de uma sociedade em determinada época e que pudesse ter valor significativo culturalmente.

${ }^{25}$ Será considerado para efeito de identificação nos documentos e cartas o termo pintura mural. Porém, se estenderá sua aplicação a arte mural de acordo com o uso do termo aqui proposto pela autora.

${ }_{26}$ Carta de Atenas 1931, Carta de Veneza 1964, dentre outras. Os documentos encontram-se disponíveis no site do ICOMOS internacional, sendo também alguns disponíveis no site do ICOMOS Brasil e no site do IPHAN.

${ }_{27}$ ICOM International Council of Museum criado em 1946 com sede em Paris, a UNESCO, United Nations Educational, Scientific and Cultural Organization constituída em novembro de 1945 e ratificada pelos membros em novembro de 1946; ICCROM International Centre for the Study of the Preservation and the Restoration of Cultural Property criado em 1956 em Paris e transferido para a atual sede em Roma em 1959. 
$\mathrm{Na}$ Carta de Veneza algumas recomendações estão relacionadas de forma indireta à preservação da arte mural e podem ser destacadas no artigo 5 que menciona que o uso social do edifício é o que permite a sua preservação e deve, portanto, respeitar a decoração e lay-out existente e as exigências ou a constituição da edificação.

No artigo 8 menciona-se que os bens como escultura, pintura ou decoração (portanto, bens móveis e integrados), que fazem parte integrante de um monumento podem apenas ser removidos, se este for o único meio de garantir a sua conservação. Recomendando então, a preservação do bem "in loco".

A adoção deste princípio pela carta, já na segunda metade do século $X X$, revela uma preocupação existente em função das inúmeras destruições das obras causadas pelas guerras e pela crescente remoção das mesmas dos seus respectivos locais de execução e origem com a finalidade de mantê-las, uma prática que era comum na época.

No artigo 9을 menciona-se que a restauração, como atividade especializada tem como objetivo revelar os valores da obra tanto estéticos quanto históricos sendo, portanto, necessário realizar estudos prévios antes de qualquer intervenção, de modo a garantir o respeito ao material original e aos documentos autênticos, além de distinguir as intervenções realizadas.

$\mathrm{O}$ artigo $11^{\circ}$, destaca a necessidade de se respeitar a contribuição que os diversos períodos da história acresceram ao edifício, cuidando para que somente com justificativas condizentes e, em circunstâncias excepcionais, remoções sejam feitas, recomendando a atribuição da responsabilidade pelas decisões em relação a este tipo de intervenção, não só a uma pessoa.

O artigo $16^{\circ}$, cita a necessidade da realização de uma documentação para qualquer trabalho de preservação, restauração e escavação. A documentação deve ser precisa com relatórios analíticos e críticos devidamente ilustrados e fotografados e deve ser realizada em todos os estágios da intervenção, antes, durante e depois. Os registros devem ser mantidos em arquivos de uma instituição pública e disponibilizados aos interessados. Recomenda-se também que os relatórios sejam publicados.

Algumas referências específicas sobre a preservação deste tipo de arte foram feitas na Carta de Restauração de 1972, do Ministério da Instrução Pública do 
Governo da Itália, carta que contém recomendações sobre as intervenções de restauração em obras de arte.

No anexo A da Carta, com as "Instruções para salvaguarda e a restauração dos objetos arqueológicos", destacam-se os cuidados com as obras quando removidas e reinstaladas no local de origem, como as pinturas e mosaicos. Destaca-se, também, a necessidade de uma atenção maior com o entorno da obra em função das variações das condições climáticas causadas por diversos fatores além da necessidade de um controle de acesso. Menciona-se ainda a necessidade de identificação da intervenção através de placas com datas, siglas ou marcas especiais.

No anexo $\mathrm{C}$ estão as providências que devem ser levadas em consideração na execução da restauração de pinturas murais. São enfatizadas medidas e cuidados as serem tomados antes, durante e depois de procedimentos de remoção da pintura mural e da sua transposição para um suporte móvel.

A conservação integrada dos bens culturais foi a questão principal debatida no Congresso do Patrimônio Arquitetônico Europeu em outubro de 1975 e introduzida no documento final a Declaração de Amsterdam.

A Declaração de Amsterdam de 1975 foi redigida pelo Conselho Europeu com objetivo de coordenar os esforços de estruturar uma abordagem para sensibilizar o público dos valores culturais, sociais e econômicos dos monumentos históricos, antigos edifícios e sítios e o que eles representavam para cada cidade e/ou país e também coordenar os esforços em adotar uma linguagem comum relacionada aos princípios e ações que provem das autoridades. A declaração introduz uma política européia comum de preservação do patrimônio arquitetônico, baseado em princípios da conservação integrada. Determina a necessidade de se considerar intrínseca a relação existente entre o planejamento urbano regional e das cidades, para o futuro e a preservação do patrimônio arquitetônico.

Recomenda-se que devem ser tomadas medidas que despertem e incentivem a população para a preservação e que garantam através da legislação, administração e financiamento e educação a aplicação de uma política de preservação por parte das autoridades.

Nessa reunião foi escrita e adotada a Carta Européia do Patrimônio Arquitetônico na qual se destacam alguns princípios, dentre os quais: a ampliação 
da preservação dos monumentos, considerando também outros edifícios que não só os excepcionais como patrimônio e englobando, também, seus respectivos entornos. Destaca ainda, que o planejamento urbano pode colocar em risco o patrimônio arquitetônico, com a perda do mesmo caso existam as pressões econômicas e de instalação de infra-estrutura viária.

Coloca-se como primordial a conservação integrada no planejamento urbano e regional para a manutenção de áreas, evitando deslocamentos, êxodo de população e agravamento das situações. Essas atividades só podem ser implementadas e mantidas com um suporte judicial, administrativo, técnico e financeiro. Além disso, é necessário um corpo técnico com a devida formação para execução dos trabalhos e, portanto, devem ser desenvolvidos meios de formação e abertas perspectivas de trabalho.

O Documento de Nara sobre a Autenticidade de 1994, elaborado em cooperação com a UNESCO, ICCROM e ICOMOS trata do respeito à diversidade cultural e à diversidade de patrimônio bem como da sua prática de preservação. A diversidade deve ser promovida como um aspecto do desenvolvimento humano.

A conservação depende dos valores atribuídos ao patrimônio e a compreensão dos valores está relacionada às informações que recebemos das fontes dos valores (fontes materiais, por escrito, orais e figurativas) que permitem criar um embasamento para a avaliação das características originais e dos aspectos de autenticidade.

A autenticidade é entendida como um requisito essencial para a qualificação dos valores do patrimônio e como fundamento para os estudos científicos de inscrição como bem cultural, inventários e planejamento de conservação e restauração.

Se os valores variam de cultura para cultura não é possível basear o juízo de valores de autenticidade em critérios fixos, mas sim dentro de contextos culturais específicos, daí a importância das fontes de informação como subsídios para a estruturação de aspectos artísticos, históricos, sociais e científicos do patrimônio em questão. Devem-se realizar esforços em incentivar comunidades a criar ferramentas e processos analíticos para determinar a autenticidade e a diversidade de patrimônios. 
Através de esforços de colaboração multidisciplinar e de diferentes conhecimentos é que se garantirá a avaliação da autenticidade. Ela deve ser documentada como guia para tratamentos e acompanhamentos de conservação e restauração futuros, além de ser sempre atualizada em função da variação de valores e circunstâncias. É necessário, então, desenvolver e facilitar a cooperação internacional permitindo ampliar a compreensão e o respeito à diversidade.

Como analisa LUXEN (2004) na realidade mais do que propriamente uma autoridade legal as cartas, os códigos de ética e princípios tem função de orientar a prática dos profissionais atuantes na área e a conduta moral dos mesmos, diferindo das convenções e recomendações promulgadas pela UNESCO, que são assinadas e ratificadas por estados membros e que, apesar de não serem leis, tem uma importância significativa para as autoridades, funcionando como diretrizes de gerenciamento, pois são preparadas de tal forma que permitam o reconhecimento e aprovação por parte da maioria das nações integrantes.

As cartas internacionais mencionadas apresentam com o passar dos anos uma crescente evolução na abrangência dos itens e na integração dos bens culturais a serem preservados, ao mesmo tempo em que refletem a necessidade de detalhamento dos bens e da forma como se deve atuar em relação a cada um, com suas respectivas especificidades.

Neste intuito, foram promulgados, em 2003, os princípios do ICOMOS que seriam de grande interesse para o objeto em estudo neste trabalho, pois, são específicos e norteadores da preservação da área de pintura mural, mas pode-se considerar, com a possível extensão para a preservação da arte mural.

Neste documento ${ }^{28}$ participantes de 10 países, reunidos na 14. a Assembléia Geral em Victoria Falls, Zimbabwe, em Outubro de 2003, listaram vários artigos para orientação mais minuciosa das práticas de preservação, conservação e restauração de pinturas murais.

\footnotetext{
${ }^{28}$ Documento elaborado por membros do ICOMOS de diferentes países e de início esquematizado em reunião entre 28 de Outubro e 01 de Novembro de 2002 em Copenhagem, recebeu acréscimos e foi finalizado em entre 8 e 9 de Maio de 2003 em Salonica. Disponível em: <http://www.international.icomos.org/charters/wallpaintings e.htm>. Acesso em: 05 jan. 2006
} 
Os princípios são recomendados para serem aplicados às pinturas murais sobre suporte inorgânicos como estuque, tijolo, argila pedra e não para aquelas sobre suportes orgânicos, tais como a madeira, o papel ou a tela.

Segundo os artigos a base fundamental da política de proteção da arte mural (artigo 1) é a execução de um inventário incluindo tanto as obras visíveis quanto aquelas que se encontram recobertas por camadas de tinta. Para a proteção das obras é necessário a existência de uma legislação que permita além da proteção em si, prover os recursos necessários para a pesquisa, monitoramento, e reconhecimento dos valores pela sociedade.

A legislação deve ainda prever sanções caso ocorram violações e execução de intervenções sem o conhecimento e autorização das autoridades. Além disso, deve ser feita a analise, avaliação do impacto de obras em relação à presença deste tipo de arte, prevendo, portanto, soluções caso isso ocorra.

A investigação, a pesquisa científica multidisciplinar (artigo 2) são elementos básicos dos trabalhos de conservação, tanto para o conhecimento da obra na sua feitura de materiais, técnicas, estilo e história quanto para avaliar o estado dos materiais e os mecanismos de degradação. Os métodos usados devem ser preferencialmente não destrutivos.

Os registro documentais (artigo 3) devem fazer parte dos trabalhos de conservação e restauração como já mencionava a Carta de Veneza. Independentemente do tipo, como relatórios analíticos, desenhos, fotografias, mapas, etc, devem documentar o estado de conservação, a metodologia usada, bem como todo o processo de intervenção.

Os registros documentais de trabalho contendo a investigação, diagnóstico e tratamento devem estar nas instituições públicas responsáveis pela preservação, no próprio local da obra "in loco," ou com os responsáveis, garantindo a disponibilidade de uma futura consulta, além de ser recomendável também, a publicação dos trabalhos.

Visando minimizar possíveis degradações (artigo 4) e futuras intervenções curativas deve-se fazer a conservação preventiva. Através do monitoramento das condições ambientais é possível evitar danos que possam surgir. 
O uso inadequado do bem cultural pode levar a sua conseqüente deterioração e dependendo do tipo do bem (sítios com pinturas) deve receber um controle de acesso.

Todavia, para que todos possam ter a oportunidade de conhecê-lo é necessário que se faça uma manutenção constante do edifício de forma a preservar a pinturas murais e garantir o acesso sendo, portanto, necessário um planejamento. A realização de um monitoramento constante permite detectar eventuais condições desfavoráveis e estabelecer um controle apropriado.

Os tratamentos de conservação e restauração (artigo 5) devem considerar a integração da obra com a arquitetura formando um todo, já que estão diretamente relacionadas. Os tratamentos têm por objetivo permitir uma melhor legibilidade da obra da suas características formais e históricas. As intervenções devem ser feitas o mínimo possível de forma a não alterar ou colocar em risco a matéria original e a autenticidade da obra, sendo aconselhável deixar evidente uma amostra estratigráfica do material que demonstre a passagem do tempo pela obra.

As intervenções representam a história da obra e devem ser respeitadas, sendo que quaisquer alterações a serem feitas devem ser analisadas de maneira crítica. Devem ser usados materiais e métodos cientificamente comprovados, tradicionais e compatíveis.

A reintegração estética deve ser feita com material diferente do original, facilmente removível e de forma distinguível. Todas as etapas da intervenção devem ser documentadas e executadas por profissionais qualificados e competentes.

Quaisquer intervenções emergênciais ou não na obra (artigo 6) devem usar materiais e métodos que permitam futuras intervenções. Devem ser evitadas as remoções e destacamentos que afetem a composição física, material e estética da obra sendo apenas adotadas quando não for possível a preservação delas "in loco".

A decisão pela remoção de obras deve ser uma decisão de equipe não restrita a um só profissional, aquele que trabalha diretamente na obra, o conservador-restaurador. Elas devem ser recolocadas "in loco" sempre que possível e tomadas medidas de proteção que evitem danos e sejam compatíveis com a obra.

$\mathrm{Na}$ implementação de projetos de conservação e restauração devem ser realizadas investigações (artigo 7) que permitam ampliar o conhecimento sobre as técnicas originais, materiais e os métodos usados em antigas práticas de 
restauração e sobre processos de degradação o que deve ser útil para a implementação de uma política de preservação sustentável. Esse conhecimento deve ser também difundido no meio profissional e para o público garantindo assim a conscientização da necessidade da preservação das obras.

Os trabalhos de conservação-restauração, disciplina especializada (artigo 8), devem ser executados por pessoas com formação e qualificação profissionais, segundo recomendação do Código de Ética do ICOM-CC Comitê de Conservação (1984) e das associações como a Confederação Européia das Associações dos Conservadores e Restauradores (E.C.C.O).

As práticas e técnicas tradicionais (artigo 9) devem ser incentivadas para que não se perca o conhecimento, segundo os princípios de Nara (1994). Todavia, a restauração não deve ser executada pelos artistas e nem pelos artesãos.

A cooperação internacional (artigo 10) e a colaboração interdisciplinar, dos conservadores-restauradores com outros colegas de outros países e instituições e especialistas relevantes deve ser incentivada.

O documento que contém esses princípios gerais, não aborda, contudo, os aspectos nacionais e regionais, cabendo a cada local trabalhar suas particularidades.

Através da abordagem desse documento contendo essa série de artigos é possível se ter um panorama da situação e das necessidades da conservação e restauração da pintura mural (arte mural) no ambiente internacional. Verifica-se a existência de situações comuns a todas as nações mesmo que em graus, locais ou em proporções diferentes.

Além disso, a pintura mural apesar da sua existência milenar como arte, ainda permanecia como uma lacuna, que fora apenas parcialmente abordada como item específico na Carta de Restauração Italiana de 1972, no qual Cesare Brandi colaborou na estruturação.

Como esclarece LUXEN (2004), apesar das cartas apresentarem normas gerais é recomendado que estas devam se combinar com as normas nacionais e próprias de cada região, motivo pelo qual o ICOMOS sempre apresenta novos textos e cartas específicos e complementares, para cada patrimônio, com o intuito de melhor esclarecer em detalhes determinadas necessidades e situações. 
Nas cartas e documentos nacionais, verificamos que no Compromisso de Brasília 1970, fruto do I Encontro dos Governadores de Estado, Secretários de Cultura e Municípios, foram estabelecidas as primeiras bases para a proteção dos bens culturais a nível Estadual e Municipal.

O documento de Salvador de 1971, resultado do II Encontro de Governadores para a preservação do patrimônio Histórico e Artístico, ratifica o encontro de Brasília e estabelece medidas complementares para a defesa do patrimônio recomendando a complementação da legislação para atendimento do conceito de ambiência.

No documento recomenda-se, ainda, a realização de planos diretores e urbanos em áreas protegidas por lei e a criação de fundos de dotações orçamentárias, doações e incentivos fiscais para atendimento da proteção de bens naturais e culturais protegidos por lei.

Recomenda-se, também, a formação, nas universidades, de centros de investigação dedicados à pesquisa do acervo natural e cultural e da formação de um corpo fiscal e técnico para atuação na proteção desses bens dos acervos culturais e naturais.

Recomenda-se, ainda, a divulgação e a promoção junto à comunidade de tradições folclóricas e da sua preservação.

Em 1989, os associados do ICOMOS, em São Paulo, analisaram o texto da Carta de Veneza que comemorava 25 anos e verificaram a necessidade de uma revisão de conceitos em função do avanço das ciências e da ampliação do campo de trabalho na preservação e na restauração.

Reconheceram que deveria ser incorporada ao texto da Carta a preservação do patrimônio natural como compreensão da harmonia entre proteção de sítios urbanos e rurais e a preservação da biodiversidade, além, de reconhecer a necessidade de se adotar sistemas de tecnologia avançada para trabalhos de restauração.

A segunda declaração de São Paulo, de 1996, apresentada anos depois, trouxe algumas recomendações dos profissionais brasileiros para a XI Assembléia Geral do ICOMOS, que consideram a preocupação com a preservação do patrimônio cultural em face da crescente expansão urbana. Recomendaram a criação de cursos de identificação, reconhecimento e registro do patrimônio cultural, organização de ações culturais em defesa dos bens naturais e divulgação dos 
mecanismos jurídicos existentes que possam embargar e impedir a destruição dos testemunhos do patrimônio cultural e natural.

A Carta de Ouro Preto resultante do IV Encontro Nacional do Ministério Público de Defesa do Patrimônio Cultural estabelece que, o mesmo regime jurídico aplicável constitucionalmente aos bens ambientais naturais será aplicável aos bens culturais e que o Poder Judiciário necessita de melhor aparelhamento, estruturação e aperfeiçoamento para cumprir efetivamente com a sua tarefa de defender o patrimônio cultural.

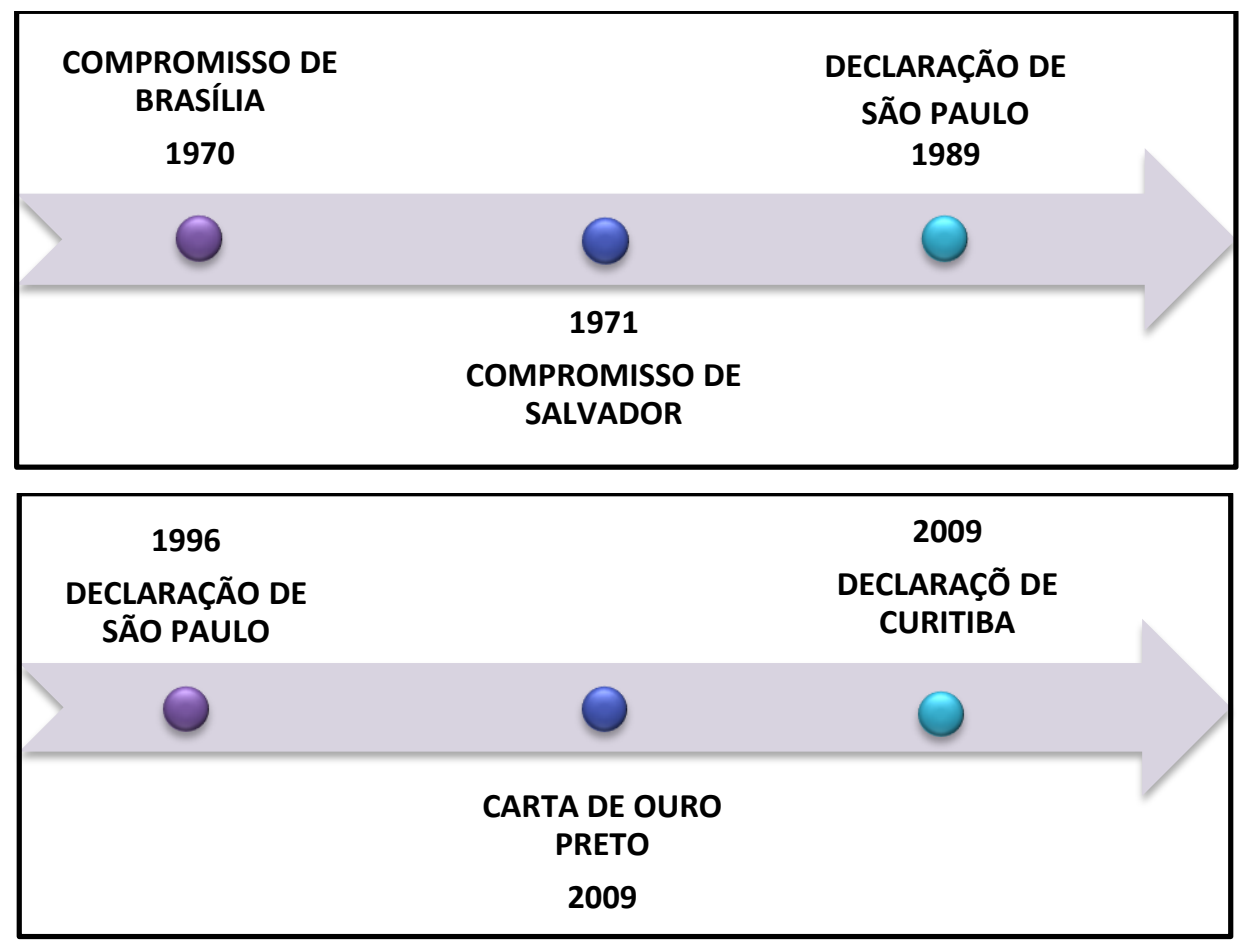

Figura 3 - Algumas Cartas Patrimoniais Nacionais

As cartas patrimoniais tanto internacionais como as nacionais com exceção da Carta de Restauração de 1972, que faz menção a alguns procedimentos de restauração de pinturas murais, têm geralmente um caráter mais abrangente, abordando questões relacionadas à preservação de bens culturais de forma mais ampla.

Com o passar dos anos as cartas vem evoluindo no sentido de manter a preservação não mais do objeto ou da edificação como algo isolado em si, mas do bem cultural com a estreita relação com seu entorno, sítio, paisagens, etc. 
Portanto, elas partem para abordagens mais administrativas, gerenciais, e legislativas que permitam uma integração maior entre as áreas, do que propriamente orientações sobre procedimentos técnicos de intervenção, evidenciando uma tendência crescente neste sentido na área de preservação.

Todavia, revisões sobre conceitos e métodos também foram foco de estudos em função da diversidade do patrimônio e culturas.

Os documentos com recomendações e princípios específicos de alguns campos de atuação também tem surgido em função da necessidade que determinados bens exigiram, por não terem sido anteriormente abordados e discutidos de forma específica em documentos.

No âmbito nacional, no texto da Declaração de São Paulo de 1989, se elenca como reflexão a necessidade do uso de técnicas avançadas no auxílio à restauração de bens culturais:

Que os sistemas de tecnologia avançada prestam aos trabalhos de restauração em todos os níveis, inclusive materiais, um grau de precisão essencial à manutenção da substância original dos acervos artísticos e documentais, dos monumentos e do patrimônio urbano edificado. (ICOMOS, 1989).

Porém, verifica-se que não houve uma evolução considerável na implantação de medidas em São Paulo, nas esferas Estadual e Municipal, que justificasse um crescimento significativo desta colaboração.

Somente neste século XXI é que se confirmou uma aproximação e colaboração maior do meio acadêmico, ensino universitário e pesquisa, com os órgãos de preservação Municipal, Estadual ${ }^{29}$ e mesmo Federal, principalmente em relação à difusão dos conceitos teóricos, princípios e da fundamentação científica de analises de materiais na prática da restauração, embora muitos profissionais da área

${ }^{29}$ Recentemente foi publicada a seguinte notícia "A FAPESP e o Conselho de Defesa do Patrimônio Histórico, Arqueológico, Artístico e Turístico (Condephaat), da Secretaria da Cultura do Estado de São Paulo (SEC), assinaram na terça-feira (21/12/2010) um convênio para a promoção da pesquisa científica e tecnológica com a finalidade de gerar conhecimento metodológico e subsidiar ações de preservação do patrimônio cultural do Estado."

"[...] o convênio estimulará a realização de estudos que contribuirão para o estabelecimento de políticas públicas de conservação do patrimônio cultural paulista." Notícia disponível em $<$ http://www.fapesp.br/materia/6054/noticias/fapesp-e-condephaat-assinam-convenio.htm>.

Acesso em: 05 jan. 2011. 
acadêmica anteriormente já estivessem envolvidos com colaborações de consultorias ou projetos na área pública. ${ }^{30}$

A causa disto talvez tenha sido a ausência de profissionais especialistas na área qualificados para o ensino e divulgação, o que só veio ocorrer em fins dos anos 1990 e no início deste século, com o ingresso destes no corpo docente. Portanto, é nesta ultima década que as bases sólidas para uma atuação interdisciplinar tem se configurado no contexto de São Paulo.

A recente Declaração de Curitiba de 2009, resultado do encontro dos membros do ICOMOS para discussão sobre "Patrimônio e Ciência" deixa evidente que a pesquisa no campo da conservação é um requisito básico para que um trabalho de conservação e restauração seja criterioso e científico.

A declaração conclui que é necessária a contribuição proporcionada pelos estudos e pesquisas sobre preservação e conservação de materiais desenvolvidos nos últimos anos e a importância do caráter multidisciplinar. Reconhece:

A inquestionável importância da ciência para se chegar à conservação qualificada e a melhor qualidade de vida integrando a conservação científica à questão social e ao desenvolvimento socioeconômico sustentável. (ICOMOS, 2009, p. 03)

O documento recomenda ao ICOMOS que sejam incentivados e realizados seminários técnicos em parcerias com entidades de preservação e se assessore na elaboração de políticas e propostas de ação, além de buscar formas de garantir a realização de obras que atendam às recomendações técnicas de preservação e que sejam qualificadas.

Ao IPHAN recomenda-se a articulação com órgãos de preservação estaduais e municipais para a realização de um mapeamento do patrimônio em risco para implantação de uma conservação sustentável. Recomenda-se, ainda, uma articulação de órgãos de preservação com universidades para a formação de grupos de pesquisa e rede de informações sobre pesquisas técnicas e soluções de problemas de preservação em diferentes bens culturais e locais.

Recomenda-se ao Ministério da Educação a implantação de universidades nas cidades históricas para incentivar a formação e divulgação das técnicas e

\footnotetext{
${ }^{30} \mathrm{~A}$ publicação Conservación del patrimônio: orientaciones de las escuelas de arquitectura em America Latina, 2006 nos traz um breve panorama da atuação acadêmica e no caso exemplifica a atuação da Universidade de São Paulo na área de preservação.
} 
práticas construtivas tradicionais e que possa contribuir para preservação do patrimônio cultural.

Diferentemente do que tem ocorrido no contexto internacional, especificamente o europeu, de onde já surgiram críticas a função da ciência na prática da conservação, no contexto brasileiro e de São Paulo essa é ainda uma realidade que está sendo implantada e, que é realmente necessária como instrumento para o conhecimento, para a credibilidade e para o reconhecimento da autenticidade do bem a ser preservado.

A nível local a cidade de São Paulo reune uma grande concentração de obras murais de períodos diversos com diferentes estilos, resultado da riqueza, do desenvolvimento arquitetônico da cidade, da expansão da metrópole, e do desenvolvimento da arquitetura moderna, concentrando vários artistas e empresas, que a essa arte aqui se dedicaram.

Além disso, muitas das obras remanescentes se encontram atualmente ameaçadas pela expansão imobiliária, pressões econômicas e de mercado, pelo abandono, pela inexistência de um trabalho de inventarização sistematizado e de uma política de conservação preventiva por parte dos órgãos responsáveis.

Essa lacuna é evidenciada na própria estrutura dos órgãos de preservação, na composição do corpo técnico e na sua atuação frente à preservação como veremos adiante. 


\section{CAPITULO III: O EXERCÍCIO DA PRÁTICA}

\subsection{A Prática Institucional}

\subsubsection{A Institucionalização da Preservação}

As instituições ligadas à preservação em nosso país surgiram somente no início século XX, num contexto marcado pela busca de uma identidade nacional e pela exaltação dos ideais modernistas introduzidos pelos intelectuais da época.

Nesse momento histórico formou-se primeiramente a instituição de preservação na esfera federal o $\operatorname{SPHAN}^{31}$ (1937) e, posteriormente, as instituições de preservação estadual o CONDEPHAAT (1968) e de preservação municipal o $\operatorname{DPH}^{32}(1975)$ / CONPRESP (1985/88).

O conceito norteador da ação destes órgãos sempre esteve pautado no entendimento do patrimônio, dos bens a serem preservados e da cultura, de acordo com a concepção de um determinado grupo. Essa linha foi instituída pelo órgão pioneiro na preservação o SPHAN e teve repercussão também nas outras duas esferas.

No caso de São Paulo, embora as idéias de valorização da cultura nacional já tivessem sido introduzidas por Mario de Andrade, diretor do Departamento de Cultura do Município de São Paulo criado em 1934, a institucionalização de um órgão de preservação só foi efetivamente ocorrer várias décadas depois.

Os novos conceitos de patrimônio, introduzidos na década de 1970, marcados pelo crescimento e pelas profundas transformações das cidades com sua expansão imobiliária, causaram algumas alterações e reflexões no ambiente institucional, mas não o suficiente para desestruturar as bases sobre as quais as

\footnotetext{
${ }^{31}$ PESSOA (2004, p. 11) expõe as diferentes nomenclaturas pelo qual passou a instituição federal e as suas respectivas fases de atuação: SPHAN - Serviço do Patrimônio Histórico e Artístico Nacional - 1937 a 1946; DPHAN Diretoria do Patrimônio Histórico e Artístico Nacional - 1946 a 1970; IPHAN Instituto do Patrimônio Histórico e Artístico Nacional - 1970 a 1979; SPHAN Secretaria do Patrimônio Histórico e Artístico Nacional - 1979 a 1990; IBPC Instituto Brasileiro do Patrimônio Cultural- 1990 a 1994; IPHAN Instituto do Patrimônio Histórico e Artístico Nacional - de 1994 até hoje.

32 O DPH (Departamento do Patrimônio Histórico) órgão da Secretaria Municipal de Cultura de São Paulo tem como atribuição identificar, proteger e fiscalizar o patrimônio da cidade e atua de forma autônoma, mas interligada ao Conpresp (Conselho Municipal de Preservação do Patrimônio Histórico), criado em 1985 e instalado definitivamente em 1988.
} 
instituições de preservação, nas três esferas, se alicerçaram refletindo o pensamento e a linha de atuação anteriormente implantados.

\section{O SPHAN}

No início do século $X X$ surgiram as primeiras manifestações preservacionistas, algumas das quais, veiculadas em revistas da época e cujos projetos de lei elaborados abordavam diferentes aspectos, ampliando-se em alguns pontos e restringindo-se em outros, ${ }^{33}$ mas que, contudo, não foram suficientes para permitir a aprovação de nenhum deles.

Em 1934, a promulgação da Constituição Federal ao atribuir ao Estado a responsabilidade de proteção dos objetos de interesse histórico e artístico do país abriu precedentes para a organização de uma instituição responsável pela preservação do patrimônio.

A legislação especifica para a preservação, abordando a questão do direito de propriedade e institucionalizando assim a Secretaria do Patrimônio Histórico e Artístico Nacional (SPHAN) só foi ser aprovada um ano depois da formação do órgão em caráter experimental (1936) com o decreto lei oㅜ 25 de 30.11.1937 de projeto de Rodrigo Mello de Franco Andrade.

A criação da instituição do patrimônio após a implantação do Estado Novo e a sua consolidação ocorreu não pela identificação dos intelectuais com a ideologia do governo ditatorial de Getúlio Vargas, mas pela apropriação das idéias modernistas adotadas pelo projeto ideológico do Estado.

A presença dos intelectuais neste meio ocorreu considerando as possibilidades de participação na construção da identidade nacional que a estruturação das novas instituições e o estabelecimento de novos programas de atuação proporcionavam.

A instituição surgiu num contexto cultural marcado pelos ideais modernistas já introduzidos pelos intelectuais na década de 1920. O escritor Mario de Andrade, teve papel significativo neste processo, pois a ele foi encomendado por Gustavo

\footnotetext{
${ }^{33}$ Várias iniciativas de projetos de lei surgiram entre as décadas de 1920 e 1930, como o projeto de Alberto Childe 1920; Luiz Cedro 1923; o projeto de Augusto de Lima 1924; Jair Lins em 1925 e Projeto de José Wanderley de Araujo Pinho 1930. Porém a concretização só se deu com o projeto de Rodrigo Melo de Franco Andrade em 1937.
} 
Capanema, a frente do Ministério da Educação e Saúde um anteprojeto para a formação do SPHAN.

Mario de Andrade, na época diretor do Departamento de Cultura do Município de São Paulo, acreditava que somente a partir de um estudo das raízes culturais brasileiras é que se poderia elaborar uma versão da identidade nacional.

O conceito norteador das ações preservacionistas do SPHAN estava fundamentado nas idéias modernistas e na construção de uma identidade nacional embasada por símbolos que evocassem a nação. A identidade nacional era, portanto fruto de escolhas realizadas pelo grupo de intelectuais que ingressaram na instituição e que passaram a construir o repertório da memória da nossa nação.

Segundo FONSECA (2005) o SPHAN, instituição pertencente ao Ministério da Educação e Saúde (MES) dirigido por Gustavo Capanema, estava estruturado em duas divisões técnicas, a Divisão de Estudos e Tombamento (DET), que englobava a Seção de Artes e a Seção de História e o Arquivo Central chefiada por Lucio Costa e a Divisão de Conservação e Restauro, chefiada por Edson Motta desde 1947.

Além da sede da instituição no Rio de Janeiro foram criadas regionais: no Norte Nordeste (1 ${ }^{a}$ DR-N/NE) coordenada por Airton Carvalho; na Bahia e Sergipe (2 $2^{\text {a }}$ DR ) coordenada por Godofredo Filho; em Minas Gerais (3ª DR) coordenada por

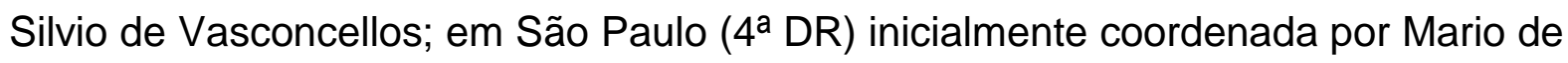
Andrade e posteriormente por Luis Saia.

O SPHAN contou também coma ajuda de colaboradores como escritores e intelectuais para realização de pesquisas e artigos que pudessem subsidiar os trabalhos em vários estados e com colaboradores estrangeiros como: Germain Bazin, Robert Smith, Hannah Levy.

Eram tombados pelo SPHAN os bens que tinham considerável valor artístico e histórico e aqueles que apresentavam valor excepcional ou significativa importância nacional.

Os valores atribuídos aos bens imóveis eram estabelecidos pelos arquitetos do corpo técnico da instituição, que tinham sua autoridade respeitada e contavam com o subsídio das pesquisas desenvolvidas para legitimar a escolha, já que o inventário geral ainda estava por ser realizado. 
Os bens eram inseridos nos quatro Livros de Tombo: 1) Livro do Tombo Arqueológico, Etnográfico e Paisagístico; 2) Livro do Tombo Histórico; 3) Livro do Tombo das Belas Artes; 4) Livro das Artes Aplicadas.

A atribuição do valor artístico relacionava-se aos aspectos formais, ao material, à técnica de execução e ao estado de conservação existindo, conforme relata FONSECA (2005), uma predominância dos aspectos estéticos sobre os aspectos históricos, que foram colocados num segundo plano já que o corpo técnico era composto basicamente de arquitetos.

Lucio Costa chefe da Divisão de Estudos e Tombamentos desempenhou papel importante, como orientador de decisões técnicas das obras de conservação e restauração que eram acatadas sem profundos questionamentos entre seus colegas.

A Carta de Atenas, documento final da Conferência do Escritório Internacional dos Museus realizado, em 1931, que fundamentava as ações de preservação pelo conceito do monumento histórico, do bem arquitetônico isolado e de valor excepcional teve repercussões no Brasil.

O tombamento se constituía, a partir de então, no instrumento jurídico de defesa do patrimônio, garantindo o direito individual do bem e a preservação do mesmo, enquanto interesse público.

Em 1965, estabelece-se uma colaboração entre a Unesco e a SPHAN para orientação das atividades de preservação e adequação da atuação do órgão em relação as práticas vigentes naquela época. Esse contato colaborou para a ampliação da noção de patrimônio e permitiu uma ampliação da preservação dos bens, que antes se restringiam aos monumentos isolados, para a preservação de conjuntos urbanos, refletindo os recentes princípios estabelecidos na Carta de Veneza 1964.

Dois outros importantes encontros de governadores ocorridos em Brasília, em 1970 e em Salvador, em 1971, trouxeram algumas modificações para a área de preservação. Os documentos resultantes dos encontros determinavam: o incentivo para a criação de órgãos estaduais e municipais de preservação para atuação complementar a atuação do SPHAN nos estados; a associação da preservação do patrimônio a um potencial turístico, incentivando a valorização e preservação de áreas naturais e de valor cultural. 
No SPHAN as alterações de valores atribuídos aos bens e a sua seleção só foram introduzidas com a ampliação da noção de patrimônio na década de 1970 como menciona FONSECA (2005), sendo marcadas pela reflexão e questionamento de alguns membros da instituição, mas não alterando substancialmente as bases sobre os quais havia se estabelecido a atuação do órgão durante todos esses anos, apesar das críticas também vindas da sociedade.

Ocorreu uma ampliação da demanda de pedidos de tombamento provenientes de diversas fontes, que não a própria instituição, causada pela crescente urbanização da cidade e pelas as ameaças de demolição de inúmeros edifícios.

Os argumentos para o tombamento eram geralmente de caráter histórico, a princípio e, posteriormente, relacionados a valores afetivos, valores relacionados ao potencial turístico, etc.

Nessa década e na seguinte o entendimento da história de forma diversa e mais ampla também se refletiu em uma nova compreensão dos valores artísticos.

O corpo técnico só sofreu algumas alterações em fins dos anos $1950 \mathrm{com}$ o acréscimo de museólogos e posteriormente de historiadores e sociólogos na década 1970, em função das novas exigências de trabalho e de discussão com profissionais de diversas áreas.

Dentro desta perspectiva de ampliação da noção de patrimônio, é criado nessa década, na gestão de Aloísio Magalhães no IPHAN, um programa: O Programa Integrado de Reconstrução de Cidades Históricas (PCH), em 1973, que previa a criação de recursos para a execução de restauração de imóveis de potencial turístico, formação de mão de obra e os incentivos tributários.

Em 1975 é criado o Centro Nacional de Referência Cultural (CNRC) dirigido por Aloísio Magalhães e composto por profissionais de diferentes áreas, vinculados a universidade e, que segundo FONSECA (2005), tinha por objetivo a reunião de informações sobre a cultura brasileira. Em função da transformação do IPHAN na Secretaria do Patrimônio Histórico Nacional (SPHAN) e da junção do $\mathrm{PCH}$ e do CNRC e da criação da Fundação Pró-Memória, em 1979, incorpora-se a prática da preservação de valores não considerados tradicionais, mas vinculados a culturas distintas ainda não reconhecidas como detentoras desse potencial. 
A atuação do Conselho Consultivo foi intensificada na década e 1980 quando este passou a participar das decisões de tombamento mais polêmicas, até então restrita a autoridade dos técnicos. Essa mudança de postura relacionava-se as dificuldades enfrentadas na avaliação dos bens não mais restrita aos valores tradicionais da história da arquitetura até então empregados.

\section{SPHAN EM SÃO PAULO}

A convite de Rodrigo Mello de Franco Andrade, Mario de Andrade iniciou seus trabalhos como diretor da regional do SPHAN em São Paulo em 1938, contudo com a implantação do Estado Novo teve que interromper seus trabalhos, retornando como colaborador em 1941, quando a instituição já estava sob a direção de Luis Saia e permanecendo até o ano de seu falecimento 1945.

O corpo técnico da regional era composto por Mario de Andrade, Luis Saia, engenheiro-arquiteto, por um historiador e um fotógrafo, que iniciaram a realização de um inventário preliminar das obras de interesse.

Mario de Andrade menciona em suas correspondências a Rodrigo Mello de Franco Andrade, atuando na sede da SPHAN no Rio de Janeiro, que São Paulo pouco poderia contribuir com seu patrimônio aos tombamentos federais ${ }^{34}$, cujos critérios, já mencionados, valorizavam basicamente a produção arquitetônica, de valor artístico e histórico e de valor excepcional.

O inventário foi então realizado e seqüencialmente seguiram os trabalhos para o tombamento e para a recuperação das obras tombadas.

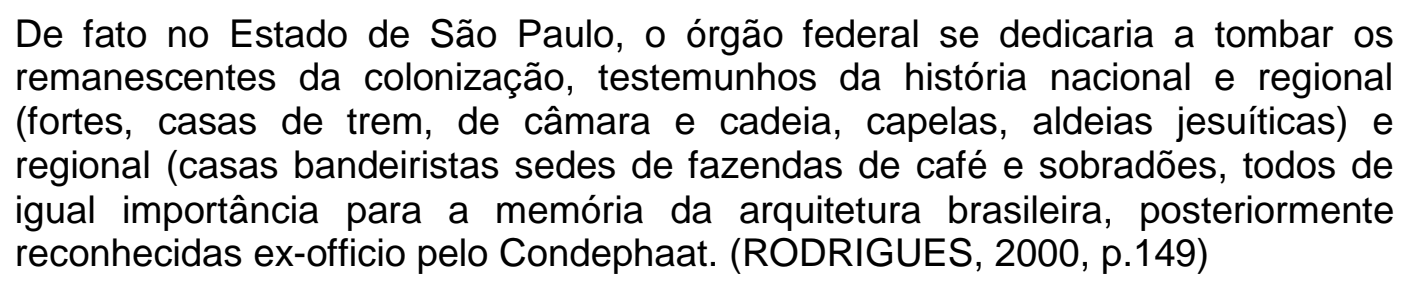

Em seu artigo ARANTES (1987) destaca que os bens valorizados em São Paulo pela instituição seguiam a vertente luso-brasileira e no interior a linha de desenvolvimento do bandeirismo a cafeicultura no Vale do Paraíba.

\footnotetext{
${ }^{34}$ ARANTES, Antonio Augusto (1987, p.50) em seu artigo, Documentos Históricos e Documentos de Cultura o autor desenvolve a uma análise da atuação do SPHAN em São Paulo.
} 
Embora a questão dos recursos financeiros fosse sempre um aspecto levantado pelos dirigentes, as primeiras obras de restauração se iniciaram em 1939. Apesar dele ter afirmado o conhecimento das orientações da Carta de Atenas pelos técnicos do IPHAN, ANDRADE (1993) disse que os trabalhos pioneiros executados pela instituição, em São Paulo, não seguiram exatamente os princípios estabelecidos pelo documento, embora, em intenções se orientassem por ele.

Outros bens relacionados ao desenvolvimento da cidade e a industrialização só foram tombados com a atuação dos órgãos estadual e municipal, em ação complementar a do SPHAN, revelando, portanto, a manutenção dos critérios tradicionais de valoração dos bens antes já utilizados.

Em 1951, a lei no1048 de 05 de junho a ser aprovada pelo legislativo, previa a criação de um órgão de patrimônio que atuaria em colaboração com o SPHAN, e foi desenvolvida com base em um projeto de Luis Saia, na época Diretor da Regional do SPHAN em São Paulo. O documento denominado Sugestões para uma fórmula de colaboração previa a divisão de responsabilidades de manutenção e de custos financeiros da preservação dos bens, entre os órgãos municipal, estadual como o SPHAN.

\section{O CONDEPHAAT}

O Condephat (Conselho de Defesa do Patrimônio Histórico, Artístico e Turístico) $^{35}$ é criado somente em 1968 pela lei n. 10.247 de 22 de outubro de 1968, promulgada no governo de Abreu Sodré.

O órgão era formado por um Conselho Deliberativo escolhido pelo Governador composto de nove membros representantes de diferentes instituições como: a Secretaria de Cultura, Esportes e Turismo, a Universidade de São Paulo (USP), Departamento de História da USP, do Instituto de Pré-História, do Instituto dos Arquitetos do Brasil (IAB), da Cúria Metropolitana de São Paulo, do Instituto Histórico e Geográfico de São Paulo e do Guarujá-Bertioga, e da Diretoria do Patrimônio Histórico e Artístico Nacional.

A lei não previa a organização de uma estrutura administrativa e, a princípio, os conselheiros acumularam tanto funções administrativas como técnicas, como menciona RODRIGUES (2000).

\footnotetext{
${ }^{35}$ Hoje o órgão denomina se Condephaat (Conselho de Defesa do Patrimônio Artístico, Arqueológico e Turístico do Estado de São Paulo)
} 
Algumas propostas de alteração na legislação foram feitas com finalidade de suprir as deficiências na lei, como os acréscimos de atividades e atribuições ao conselho, a competência do tombamento e dos usos dos bens públicos, etc. Em 1969 foi aprovado o decreto com as alterações.

Rodrigues aponta: "Ao iniciar seus trabalhos o Condephaat não contava com um setor técnico; embora não estruturado por lei este começaria a ser formado em outubro de 1969, por profissionais comissionados de outras secretarias." (RODRIGUES, 2000, p. 54).

Outro decreto n. 52.620 de 21 de janeiro de 1971 criou a Secretaria Executiva do Condephaat e estabeleceu a composição e as atribuições das unidades técnicas do órgão. As unidades componentes eram: Comissão Técnica de Estudos e Tombamento; Serviço Técnico de Conservação e Restauro (STCR), Seção TécnicoAuxiliar; e Secretaria de Administração.

O corpo técnico permanente do STCR só surgiu em 1982 e era composto basicamente de arquitetos e historiadores.

O conceito norteador da atuação do Condephaat estava fundamentado na prática da ação emergencial de não destruição dos bens, como representativos de valores da história oficial regional e da arquitetura.

Os critérios de valoração e seleção dos bens de acordo com SANTOS ${ }^{36}$ nunca foram bem definidos e cada Conselheiro tinha uma linha de atuação própria dependendo, portanto, de cada um deles.

Dentro do Conselho haviam divergências quanto aos critérios adotados para a escolha dos bens. As divergências referiam-se à valorização do bem enquanto documento da arquitetura, avaliando, portanto, as suas características formais, materiais e técnicas, ou à valorização do bem como testemunho da história, da sua relação com os heróis do passado ou da relação com uma classe social de significativa importância.

O ponto em comum entre as duas tendências era a valorização do bandeirismo e das edificações do período de ocupação no litoral, pois representavam momentos importantes na história nacional e regional.

RODRIGUES (2000) especifica a distinção de três fases de atuação do Condephaat, segundo critérios e conceitos diferenciados, que mesmo introduzidos

\footnotetext{
${ }^{36}$ Apud RODRIGUES (2000)
} 
não alteraram os procedimentos seguidos anteriormente: 1a fase (1969-1975) ainda extremamente ligada aos critérios tradicionais de eleição do patrimônio edificado; $2^{\text {a }}$ fase (1975-1982) fase de abertura conceitual atribuindo a relação do patrimônio com a gestão urbana; 3a fase (1982-1987) fase de abertura com uma maior participação dos técnicos nas decisões do Conselho.

Nos anos de 1970 o Condephaat deparou-se com a necessidade de aplicação de medidas que acompanhassem as alterações causadas pela inserção do patrimônio na política de preservação urbana.

Em 1971 através da criação de uma comissão buscou-se estabelecer uma linha de critérios a ser seguida para atuação da instância técnica do Conselho, a Comissão Técnica de Estudos e Tombamentos, chefiada por Carlos Lemos.

Em 1972, com a proposta de Lemos iniciou-se o inventário dos bens, base para o exercício das outras atividades de análise e fiscalização dos bens. Os tombamentos, porém, não seriam orientados pelo inventário, como relata RODRIGUES (2000), mas pelas indicações de Conselheiros e pela demanda da sociedade.

Entre os anos de 1975 e 1976 o órgão seria integrado à outra secretaria e o Conselho terá sua composição alterada, com acréscimo de outros membros.

Dois grandes marcos no pensamento dos membros do Condephaat podem ser destacados, como explica RODRIGUES (2000: o primeiro foi o Curso de Hugues Varine-Bohan ${ }^{37}$ em 1974, introduzindo um novo conceito de patrimônio, criando uma abertura conceitual e questionando os procedimentos técnicos de realização de inventário até então utilizados; o segundo foi O Seminário Cultura, Patrimônio e Preservação, em 1983, que incorporou a memória como um dos conceitos norteadores da ação preservacionista, permitindo o aparecimento de novos trabalhos no Condephaat.

Neste período sob a gestão de Antonio Augusto Arantes, a 3aㅗ fase (19821987) correspondeu a uma fase de abertura democrática no contexto político com reflexos, também, na maior participação dos técnicos de diferentes áreas nas decisões do Conselho.

\footnotetext{
${ }^{37}$ Hugues Varine-Bohan era ex diretor do ICOM e ministrou o curso de Restauração e Conservação de Monumentos e Conjuntos Históricos, num convênio do MEC com a Universidade de São Paulo e coordenação do Iphan, Condephaat e Departamento de História da Arquitetura da FAU/USP.
} 
A iniciativa e o interesse da sociedade na preservação do patrimônio, como exercício de seus direitos e de cidadania, facilitou a divulgação e a aproximação das ações preservacionistas do Condephaat da sociedade.

Em 1984, um documento estabelecendo diretrizes para uma nova política de atuação do Condephaat foi apresentado pelos técnicos e conselheiros. O documento atribuía à noção de patrimônio cultural aos produtos da ação humana e da natureza.

O documento das diretrizes, como descreve RODRIGUES (2000), estabeleceu que o Condephaat atuaria a partir do conceito de que o patrimônio é um eixo "de identidade social" e serve para o "enriquecimento da qualidade de vida". Caberia ao Estado atuar através de atividades de identificação, proteção e de valorização do patrimônio cultural. Os critérios de tombamento levariam em consideração os valores cognitivos, formais e afetivos dos bens. Todavia, a proposta encontraria resistência de ordem política e operacional.

Outro documento elaborado em 1985 por Ulpiano Bezerra de Meneses sobre as diretrizes de atuação do órgão reforçava as idéias contidas no documento anterior ao das diretrizes. O novo documento ressaltava a necessidade de articulação da administração com os órgãos de pesquisa, o apoio financeiro, uma ação cultural pedagógica, valorizava ainda a pesquisa científica e introduzia novos instrumentos de preservação além do tombamento, como a listagem.

Apesar dos inúmeros esforços de alteração da atuação do órgão através da elaboração de diferentes planos, documentos, a estrutura do Condephaat, de acordo com RODRIGUES (2000), esta permaneceu inalterada e:

A ampliação gradativa do campo conceitual que baliza os trabalhos do órgão, e a extensão de sua competência ao meio ambiente, ao mesmo tempo em que deixavam vislumbrar a potencialidade política do patrimônio, desnudavam os impedimentos à sua plena realização; essa possibilidade mostrou não se situar apenas no campo do conhecimento, mas também, mais claramente, no da vontade política dos governantes e da sociedade. (RODRIGUES, 2000, p. 144)

A nível estadual a maior dificuldade enfrentada foi a falta de definição de uma política ou um plano de atuação que permitisse dar uma seqüência mais ordenada às ações do órgão, embora, ao longo dos anos, várias tentativas de implantação de diretrizes de atuação tenham sido propostas. 


\section{O CONPRESP e O DEPARTAMENTO DO PATRIMONIO HISTÓRICO (DPH)}

Em 1934 é Criado o Departamento de Cultura da Prefeitura Municipal de São Paulo na gestão de Fábio Prado com projeto de Mario de Andrade e Paulo Duarte. O departamento surge num contexto de reação ao regime totalitário e com objetivo de promover a o desenvolvimento da educação e da cultura.

O departamento tinha como atribuições: as atividades de expansão da rede de bibliotecas, criação de parques infantis, organização de arquivos documentais; desenvolvimento de pesquisas sobre folclore, etnográficas, etc.

Seu dirigente, Mario de Andrade, propôs a ampliação do órgão, antes restrito as atividades na área educacional e promoção cultural, para atividades na área de preservação do patrimônio. Em 1975, o departamento sofreu alterações e foi criada a Secretaria Municipal de Cultura.

O Departamento do Patrimônio Histórico (DPH) originou-se do Departamento de Cultura e foi criado pela Lei oㅜ 8.204 de 21 de janeiro de 1975 e, posteriormente, sofreu alterações pela Lei o 8.252 , de 21 de maio de 1975. Dentre as suas atribuições estavam à identificação, proteção e fiscalização do patrimônio cultural e natural da cidade de São Paulo.

Ele foi composto por três divisões técnicas e uma administrativa: Divisão de Iconografia e Museus; Divisão do Arquivo Histórico Washington Luiz; e Divisão Técnica de Preservação.

A Divisão de Preservação, que elaborou o IGEPAC-SP (Inventário Geral do Patrimônio Ambiental, Cultural e Urbano de São Paulo), realiza pesquisas e organiza o material técnico de suporte aos pedidos de tombamento, elabora projetos de restauração para bens públicos, orienta e fiscaliza as intervenções em obras de arte em espaços públicos e intervenções em obras arquitetônicas de bens a serem preservados.

O DPH fornece, também, o apoio técnico ao CONPRESP, o Conselho Municipal de Preservação do Patrimônio Histórico, Cultural e Ambiental da Cidade de São Paulo criado pela Lei no 10.032, de 27 de dezembro de 1985, e alterado pela Lei no 10.236 , de 16 de dezembro de 1986 e pela Lei oㅜ 14.516 de 11 de outubro de 2007.

O CONPRESP, órgão ligado a Secretaria Municipal de Cultura é responsável pela aplicação da legislação de tombamento municipal e pela criação de diretrizes 
de preservação para os bens. Atua em parceria com o DPH apesar de serem órgãos independentes e autônomos. Apesar de criado em 1985/86 só foi ser realmente instalado em 20 de outubro de 1988 e a partir de então, passam a serem tombados os bens de interesse do Município pelo CONPRESP.

Os bens já preservados pelas instâncias federal e estadual foram tombados em 1991, através de tombamento ex-officio, artigo 7 da Lei $n^{\circ} 10.032$, de 27 de dezembro de 1985.

O crescente processo de urbanização da cidade e as constantes demolições de bens imóveis exigiam urgência nas medidas de proteção do patrimônio. São Paulo diferia de outras cidades pela sua dimensão e pela diversidade de tipologias a serem consideradas como patrimônio.

Os critérios de seleção dos bens, nessa década de 80 , já eram mais amplos do que aqueles estabelecidos pelo SPHAN. Porém, diferentemente do que ocorreu no inicio do SPHAN e do CONDEPHAAT, os bens de interesse de preservação do município foram sendo reunidos através do Serviço Técnico de Conservação e Restauro (STCR) iniciado em 1983 e a preservação do patrimônio já estava associada à preservação do ambiente urbano.

Essa associação já estava ocorrendo por iniciativa de instituições vinculadas ao planejamento urbano em âmbito estadual através da Política de Desenvolvimento Urbano e Regional do Estado, que incluía o Programa de Revitalização do Patrimônio Ambiental Urbano.

Uma listagem de bens de valor cultural foi iniciada em 1974 e coordenada por Carlos Lemos e Benedito Lima de Toledo através da Coordenadoria Geral de Planejamento (COGEP), ${ }^{38}$ hoje Secretaria Municipal de Planejamento da Prefeitura Municipal de São Paulo (SEMPLA). Rodrigues menciona que:

O conceito de patrimônio alargava-se, portanto. O trabalho, inspirado na experiência francesa de criação de "setores preservados" tinha por objetivo orientar a nova legislação de zoneamento urbano de São Paulo, cidade então convulsionada pelas obras do Metrô, a partir da consideração de "manchas", nas quais se incluíam os bens culturais significativos dos diferentes períodos de desenvolvimento da cidade, classificadas como Z8-200 e sujeitas a medidas específicas incluídas na legislação de uso e ocupação do solo do município, a lei no 8328/75 (RODRIGUES, 2000, p. 72)

\footnotetext{
${ }^{38}$ No período a COGEP era presidida por João Evangelista Leão.
} 
Os critérios do plano de preservação do Inventário Geral do Patrimônio Ambiental, Cultural e Urbano de São Paulo o IGEPAC procuravam considerar a importância da ambiência, da paisagem urbana e não só o imóvel isolado. O inventário foi iniciado 1983 com os sítios naturais, históricos e arquitetônicos, considerando não somente os bens "monumentais", mas aqueles relacionados à organização do espaço urbano, indicando as manchas urbanas, significativas para proteção. Iniciam-se os estudos dos bairros mais antigos.

O tombamento era até então, no âmbito federal e estadual, o instrumento de preservação. Na municipalidade, até 1988 , só existia a lei de zoneamento oㅡ 8328/75 e 9725/84 e a lei de criação do Conpresp no 10032/85.

A lei de zoneamento № 8328/75, que estabeleceu o uso e a ocupação do solo da cidade determinava que antes de qualquer iniciativa de alteração de bens que se encontravam na listagem deveria ser feita uma consulta ao COGEP.

Foram desenvolvidos vários inventários entre 1985 a 2003 e também inventários temáticos desenvolvidos na década de 1990, como o Inventário de Obras Escultóricas, o Inventário de Cemitérios, porém sem continuidade. Em 1995 por solicitação do DOCOMOMO Brasil iniciou-se o inventário da Arquitetura Moderna Paulistana (IAM).

\subsubsection{Preservação de Bens Integrados}

Antes de iniciarmos uma reflexão sobre a prática da preservação dos bens integrados no território paulistano, é necessário definir o que são "os bens integrados", quais as características específicas que os torna particulares no seu contexto, exigindo uma atenção e intervenção mais cuidadosa e de que modo foram implantados os trabalhos de conservação e restauração nesta área.

O termo "bens integrados" tem sido utilizado recentemente em nosso contexto segundo COSTA (1987), para caracterizar todos os bens que se encontram inseridos na edificação e cuja ausência implica na descaracterização da unidade da obra como: a talha, o retábulo, o painel de azulejos, a pintura mural, a pintura de forro, etc. 
Essa nomenclatura passou a ser usada a partir do inventário do acervo promovido pela SPHAN /Pró Memória, ${ }^{39}$ mas a preocupação com as obras que integram as edificações já vem de longa data, embora nem sempre recursos puderam ser destinados à preservação das mesmas, sendo apenas destinados à execução de trabalhos de recuperação de bens imóveis, arquitetônicos, muitas vezes se restringindo a recuperação estrutural, de telhado, da vedação e do revestimento.

Mesmo com o predomínio do incentivo dado a preservação dos bens imóveis a prática de intervenção nos bens arquitetônicos e em bens móveis e integrados ainda era um campo a ser explorado inicialmente pelo corpo técnico do SPHAN e posteriormente pelo das outras instâncias.

$\mathrm{Na}$ gestão de Rodrigo Mello de Franco Andrade, durante o período da fase áurea do SPHAN, de 1937 a 1957, os técnicos e colaboradores puderam contar com o apoio da direção para a realização de pesquisas e de trabalhos na área, apesar dos recursos não terem sido abundantes.

Diante da diversidade dos bens encontrados móveis e integrados e da necessidade de intervenções que exigiam um conhecimento técnico mais especializado do que aquele do corpo técnico, predominantemente de arquitetos, que compunha a instituição, foram tomadas providências para a estruturação do Setor de Conservação e Restauro.

Somente em 1944, já com quase 10 anos de existência do SPHAN e sob a chefia de Lucio Costa do Departamento de Estudos e Tombamento (DET) é que o artista mineiro Edson Motta (1910-1981) ${ }^{40}$ foi convidado por Rodrigo Mello Franco de Andrade para organizar o Setor de Recuperação de Obras de Arte do Serviço do Patrimônio Histórico e Artístico Nacional.

A experiência como bolsista de especialização em conservação e restauração de obras de arte da Fundação Rockefeller, no período de 1944 a 1946 no Fogg Art Museum em Cambridge, instituição pertencente à Universidade de Harvard nos Estados Unidos, permitiu que, em 1947, de volta ao Brasil ele iniciasse a etapa de

\footnotetext{
39 Para RAMOS FILHO (1987) a nomenclatura dos bens móveis e integrados é oficialmente aceita pelo órgão federal.

40 Edson Motta (1910-1981) foi um dos fundadores do Grupo Bernardelli em 1931 junto com outros artistas como Ado Malagoli (1906 - 1994), José Pancetti (1902 - 1958), Milton Dacosta (1915 - 1988$)$, Quirino Campofiorito (1902 - 1993), Manoel Santiago (1897- 1987), Bruno Lechowski (1887 - 1941$).$
} 
planejamento e implantação dos trabalhos, já na direção do departamento como conservador-chefe até 1976.

Todavia, menciona RAMOS FILHO (1987), a diversidade dos bens a serem preservados, os bens móveis e bens integrados, exigiu também uma atuação distinta, sendo planejada a criação de ateliês fixos, ligados aos museus do SPHAN e ateliês móveis, nos locais onde se encontravam os bens que faziam parte dos monumentos.

O restaurador Edson Motta procurou estruturar de maneira sistemática os trabalhos nesse setor de preservação de bens móveis e integrados, centralizando as atividades no ateliê da instituição no Rio de Janeiro. Alguns fatores como a falta de profissionais habilitados, de material e equipamentos e as distâncias dificultaram o trabalho.

O apoio da comunidade internacional veio em 1964 com auxilio do diretor do Instituto Real do Patrimônio Histórico e Artístico da Bélgica, o Prof. Paul Coremans, que, além de ajudar na criação de uma política de restauração de bens móveis e integrados para o Brasil, permitiu que profissionais pudessem ter uma especialização na área em uma conceituada instituição o Instituto Real de Estudos e Conservação do Patrimônio Artístico Belga (IRPA).

O plano previa que a coordenação dessas atividades fosse mantida no RJ, mas diante das diversas dificuldades encontradas optou-se pela descentralização e pela presença de um restaurador em cada regional responsável pelo ateliê a ser criado e por sua equipe.

Foram instaladas regionais somente em Estados com grande número de bens com grande valor expressivo sendo priorizados os Estado de Minas Gerais, Bahia, Rio de Janeiro e Pernambuco. Alguns profissionais foram designados para a coordenação como: Jair Afonso Inácio (1932-1982) em Minas Gerais; Fernando Barreto em Pernambuco; João José Rescala (1910-1986) na Bahia; Ado Malagoli (1906-1994) que não chegou a assumir a regional do Rio Grande do Sul; e Edson Motta (1910-1981) no Rio de Janeiro.

O início dos anos 1960 é marcado pela descentralização das atividades de restauração do SPHAN, por investimentos em formação profissional na Bélgica para aqueles que coordenariam as respectivas regionais e pela difusão das informações 
com aulas em disciplinas de restauração em algumas universidades nos respectivos estados dos coordenadores com formação superior.

Na década de 1970, também foram se constituindo os órgãos de preservação estadual e municipal em cuja estrutura se previa a organização de forma similar ao SPHAN com ateliê central e outros dispersos nos locais a serem preservados.

Apesar do aumento nas atividades práticas de conservação e restauração, isso se refletiu apenas parcialmente em mudanças de atuação nos critérios e procedimentos por parte das instituições públicas em São Paulo como o IPHAN/SP, o CONDEPHAAT e o DPH, principalmente no que se refere à preservação dos bens integrados.

A composição do corpo técnico ainda permanecia restrita a algumas categorias com reduzida participação de profissionais atuantes e com conhecimentos em atividades de conservação e restauração de bens integrados, já que o ingresso de novos profissionais estava associado à realização de concursos públicos

A renovação do quadro institucional, ainda que de maneira tímida, foi foco de projetos institucionais recentes, pois o último ingresso de profissionais na instituição federal foi em 2005 com o concurso público para várias áreas técnicas: engenharia, arquitetura, museologia, história, historia da arte; ciências sociais, educação, arqueologia, gestão bibliográfica e gestão de documentos, mas não para a área de conservação e restauração de bens integrados. Somente em 2009 foram abertas em concurso duas vagas para todo o país para essa área de conservação e restauração, o que com certeza não supriu as necessidades.

A inexistência de uma instituição ou um centro que congregue atividades de pesquisa com atividades práticas e de formação de graduação em São Paulo, pode ter contribuído para o retardamento e para a dificuldade de compreensão das atribuições técnicas do profissional e para o exercício de uma prática de preservação de bens integrados não associada a programas de ação interligados à preservação arquitetônica e, ainda, desvinculada da colaboração com a área científica.

Atualmente no contexto paulistano têm ocorrido muitos seminários, workshops e eventos patrocinados e em colaboração com instituições de preservação, divulgando atividades na área, favorecendo o aperfeiçoamento dos 
profissionais e aumentando a cooperação entre a área científica e o profissional da conservação.

Somente no século XXI, na última década, verificamos uma aproximação maior das ciências naturais com a área de conservação e restauração em benefício da preservação dos bens culturais móveis e integrados de São Paulo. ${ }^{41}$

As considerações que podemos realizar desta evolução da prática institucional é que no contexto da ação preservacionista em São Paulo, a participação de representantes do patrimônio federal como o caso de Luis Saia, que era representante do SPHAN e membro do Conselho Deliberativo nos primeiros anos de atuação do Condephaat, de janeiro de 1969 a maio de 1975, colaborou para a manutenção dos critérios e métodos utilizados pela atuação do SPHAN (Secretaria do Patrimônio Histórico e Artístico Nacional) na prática institucional do Condephaat. Esta associação é perfeitamente compreensível, pois a referência da experiência prática na área de preservação adivinha do órgão federal, já com seus trinta anos de atuação.

Esses critérios e métodos, embora ainda repetidos na atuação do $\mathrm{DPH}$, foram aos poucos se alterando em função das necessidades vigentes e da vinculação do patrimônio com a preservação do ambiente urbano, que passou a exigir novas reflexões e diretrizes de atuação.

Com relação à preservação de bens móveis e integrados a carência de profissionais especializados em conservação e restauração fez com que vários profissionais que atuavam no setor artístico e da construção fossem chamados para a execução de atividades relacionadas, até que fosse constituído um grupo com a formação especializada na área, adquirida geralmente fora do país, em instituições da Europa, EUA ou México.

No caso de São Paulo a atuação na execução destes serviços na esfera federal ocorreu, a princípio, pela intervenção em bens integrados e móveis, pelo restaurador Edson Motta, sendo posteriormente assumida a coordenação na década de 80 por funcionários da instituição e a execução dos serviços feita pela contratação de profissionais terceirizados, de fora do quadro técnico institucional.

\footnotetext{
${ }^{41}$ Alguns eventos da área de ciências aplicados à preservação de bens culturais foram listados pelo Prof. Carlos Roberto Apolloni do LFNA / DF /UEL e evidenciam o crescimento das pesquisas na área nos últimos 10 anos. Disponível em: $<$ http://www.sbf1.sbfisica.org.br/eventos/extras/lasmac/Reuni\%F5es\%20Arqueometria\%20\&\%20afins \%20Brasil.pdf>. Acesso em: 02 nov. 2009.
} 
$\mathrm{Na}$ esfera estadual a presença de profissionais ligados a atividades práticas de conservação e restauração não ocorreu, pois pelo histórico da instituição era atribuído ao Conselho Consultivo uma força de atuação mais intensa do que a da área técnica.

No contexto municipal a estrutura criada pelo Departamento do Patrimônio Histórico, com setores técnicos e suas respectivas atribuições, possibilitou um acompanhamento relativo das intervenções realizadas nas obras a serem preservadas.

A preservação de bens móveis e integrados seus procedimentos e métodos adotados está intimamente associada à preservação do bem arquitetônico e, portanto, à atribuição de valores que é feita ao bem imóvel. O valor atribuído a esse bem é que irá determinar as diretrizes da sua conservação. Porém, a preservação física da matéria exige o conhecimento específico e técnico de um profissional capacitado para tal atividade. Todavia, a insuficiência de um corpo técnico de formação mais específica nas áreas de conservação e restauração nas três instâncias em São Paulo dificultou o processo.

A partir de fins da década de 1990, o crescente envolvimento dos profissionais da área de preservação com a área técnica e científica tem contribuído para um importante desfecho na execução dos trabalhos, e na eventual alteração de conceitos, métodos e procedimentos até então utilizados.

O que temos observado recentemente é um aumento significativo dos profissionais prestadores de serviços, que atuam na área de preservação, na execução prática das obras e, cuja grande maioria não pertence ao corpo técnico institucional, já que poucas são as oportunidades de ingresso através de concursos públicos.

A constatação deste fato nos leva a refletir sobre a necessidade: da formação profissional, ${ }^{42}$ do planejamento e estruturação dos projetos; da ação conjunta e articulada das instituições, através de seus bancos de dados e informações; e do acompanhamento e supervisão das obras.

A prática da preservação está relacionada não só às questões conceituais, técnicas, mas muitas vezes se encontra inserida num contexto de questões políticas

${ }^{42}$ Em 2008 teve início o primeiro curso de graduação em conservação e restauração em nível superior do país que é oferecido pelo Centro de Conservação e Restauração de Bens Culturais da Escola de Belas Artes da Universidade Federal de Minas Gerais, EBA/UFMG. 
e administrativas e, independentemente do grupo de interesse que venha atender, sempre constituirá uma ação de intervenção com resultados que devem passar por avaliações.

$\mathrm{Na}$ área de preservação, independentemente do setor administrativo ou técnico, sempre existiu e existirá uma ou mais personalidades marcantes ou figuras carismáticas, a serem lembradas pela sua intensa atuação movidas por interesses dos mais diversos, como idealismo, vaidade, empenho, articulação política, capacidade intelectual, habilidades artísticas, etc, que, com uma atuação mais determinada, algumas vezes enérgica e, sobretudo persistente, marcará a instituição e conseqüentemente ingressará na história da preservação deste país. Isso se aplica tanto no campo da arquitetura quanto no da conservação e restauração de bens móveis e integrados.

Sem ignorar o mérito da produção deixada por essas pessoas em suas respectivas instituições, precisamos constantemente reavaliar os critérios e métodos utilizados de forma a adequar as ações preservacionistas às novas realidades e exigências que emergem de uma sociedade em freqüente transformação e que estabelece novos conceitos e valores. Isso, contudo, implicará algumas vezes em críticas nem sempre muito bem recebidas, porém, que fazem parte do processo de amadurecimento dos profissionais que se dedicam a esta área de preservação.

No entanto, no contexto geral em que se vive hoje, de conscientização da sociedade para importância de preservação ambiental como qualidade de vida, as chances de se criar também uma abertura e oportunidade maior de participação da sociedade para a preservação do nosso patrimônio (imóvel, móvel, integrado, imaterial, etc) são grandes.

\subsubsection{Inventário e Catalogação}

O termo inventariar é usado para designar a execução do inventário, a relação do conjunto de bens, descrição, relação ou lista minuciosa, onde se encontram registrados os bens.

$\mathrm{Na}$ área de preservação essa relação de bens tem um objetivo específico de identificar, reconhecer e classificar objetos, locais e áreas a fim de delimitar um 
contexto de estudo, pesquisa e articulação de informações, que permitam dar um sentido e atribuir um valor ao bem a ser considerado.

O reconhecimento do valor é o primeiro passo para a preservação e a conservação do patrimônio. A aplicação do inventário como forma de proteção já é uma prática de tempos remotos no continente europeu.

O inventário dos bens integrados é um instrumento importante para identificação e conhecimento da obra, conhecimento da produção de um artista, e serve, portanto, de ferramenta básica para estudos posteriores de ordem estilística, formal, de história da técnica e da conservação das obras.

A participação de vários profissionais entre arquitetos, historiadores, historiadores da arte, fotógrafos e conservadores/restauradores na equipe responsável pela realização do inventário só irá agregar esforços e consideráveis resultados, uma vez estabelecida a colaboração entre eles.

No que tange a arte mural, que é um bem integrado à edificação, na pesquisa de campo realizada pela autora junto às instituições de preservação não foram encontrados inventários específicos sobre este tipo de arte.

No caso do IPHAN verificou-se a existência de um inventário sistematizado de bens móveis e integrados, desenvolvido principalmente na década de $1990 \mathrm{com}$ apoio da Fundação VITAE e com a elaboração de uma ficha catalográfica de base e um manual de preenchimento da mesma, que permitiu uma relativa uniformização em várias partes do território. Todavia, no caso de São Paulo não se evidenciou a existência do inventário sistematizado de bens móveis e integrados desenvolvido, segundo esse padrão, que foi aplicado em outras partes do território nacional, nem registros relacionados à arte mural.

A inexistência destes registros é perfeitamente compreensível na esfera federal em função da ênfase institucional dada a preservação de bens do período colonial, ou de valor excepcional, sendo que este tipo de arte em São Paulo teve maior representatividade em períodos posteriores da história da cidade, associados ao clico do café e do desenvolvimento da arquitetura eclética em fins do século XIX, e da arquitetura moderna já no século XX.

No caso do CONDEPHAAT foi encontrado na base de dados das obras de arte tombadas pela instituição o registro do acervo da Capela do Hospital das Clínicas, que se encontra inserido no livro das artes. O acervo inclui as obras de 
Fúlvio Pennacchi, autor de dois murais executados na parede localizada atrás do altar.

Somente no órgão municipal de preservação o D.P.H. foi possível tomar conhecimento de um levantamento sobre murais, iniciado por um funcionário da instituição, mas cujo trabalho foi interrompido e não teve mais continuidade. ${ }^{43}$

Todavia, não há registro deste trabalho em bases de dados oficial da instituição, nem a sua disponibilização ou divulgação como ocorre com as obras de arte públicas. ${ }^{44}$ Portanto, não se configura como informação oficial da instituição.

A importância do inventário é destacada na carta de Atenas no item VII relacionado à Conservação dos Monumentos e a Colaboração Internacional. O item incentiva que cada nação através das devidas instituições competentes fizesse os inventários de seus monumentos históricos nacionais com informações e fotos e os publicassem, além de constituir arquivos e reunir os documentos relativos aos monumentos históricos.

[...] VII- A conservação de monumentos e colaboração internacional. ${ }^{45}$

c) Valor de documentação internacional

A conferência expressa o desejo que:

1) Cada país ou as instituições criadas ou reconhecidas como competentes para este fim, publiquem um inventário dos monumentos antigos, com fotografias e notas explicativas.

2) Cada país constitua registros oficiais que devem conter todos os documentos relativos aos seus monumentos históricos

3) Cada país apresente uma cópia de suas publicações sobre os monumentos artísticos e históricos no escritório de museus internacionais.

${ }^{43}$ As informações foram passadas a autora por alguns funcionários e nos pareceu evidente que o trabalho, apesar do conhecimento de várias pessoas dentro da instituição era algo executado por iniciativa particular e não configurava um projeto ou intenção institucional, mesmo porque os responsáveis pela conservação não tinham conhecimento da inserção de alguma informação sobre ele no sistema de documentação informatizada. Além disso, informações fornecidas pela pessoa responsável pelo levantamento à autora evidenciaram que se tratava de um trabalho particular.

44 Informações sobre as obras de arte públicas são fornecidas pela Seção Técnica de Levantamentos e Pesquisa Divisão de Preservação - DPH. Estão disponíveis em:

$<$ http://www.prefeitura.sp.gov.br/cidade/secretarias/cultura/patrimonio historico/adote obra/index.php ? $\mathrm{p}=4483>$. Acesso em: 12 fev. 2011.

${ }^{45}[.$.$] VII - The Conservation of Monuments and International Collaboration.c) Value of international$ documentation. The Conference expresses the wish that: 1) Each country, or the institutions created or recognised competent for this purpose, publish an inventory of ancient monuments, with photographs and explanatory notes; 2) Each country constitute official records which shall contain all documents relating to its historic monuments; 3) Each country deposit copies of its publications on artistic and historic monuments with the International Museums Office; 4) The Office devote a portion of its publications to articles on the general processes and methods employed in the preservation of historic monuments; 5) The Office study the best means of utilising the information so centralised. 
4) O Instituto dedique uma parte de suas publicações para os artigos sobre os processos gerais e os métodos utilizados para a preservação dos monumentos históricos.

5) O Instituto estude a melhor forma de utilizar informações tão centralizadas

(ICOMOS-CARTA DE ATENAS, 1931, tradução nossa)

A necessidade deste inventário a nível Municipal não só para os bens imóveis e móveis, mas, principalmente, para os bens integrados, como o caso da arte mural é primordial para o conhecimento deste tipo de arte, até então, não muito estudado ou divulgado. A reunião das informações em uma base de dados conjunta permite a rápida associação das informações e o estabelecimento de correlações entre elas, gerando a integração entre o bem arquitetônico e os bens integrados, a arte mural.

O inventário, como instrumento da preservação, através da documentação e dos registros do processo, constitui, também, um importante instrumento de investigação, monitoramento, fiscalização e gerenciamento do bem para tomada de decisões e estruturação de políticas de conservação do patrimônio cultural.

\subsubsection{Documentação}

Documentar é o ato de juntar provas ou documentos, ou provar por meio deles. Na área de preservação o provar adquire o sentido de registrar para conhecer e reconhecer com auxilio das informações o valor e significado do bem cultural.

A documentação é constituída pelo conjunto de informações sobre a obra de natureza textual, gráfica e fotográfica, que permite não só o seu conhecimento, e o reconhecimento do valor e importância como também, através dos dados obtidos, criar uma base de referência que fundamentará o desenvolvimento de projetos futuros no âmbito da pesquisa, educação, conservação, restauração e o seu gerenciamento.

O processo de documentação representa uma importante etapa da preservação e permite que outras gerações possam ter acesso a um registro caso o patrimônio seja perdido, por agentes naturais (como catástrofes) e ou agentes antrópicos (guerras, conflitos, expansões urbanas, etc). Uma documentação bem 
realizada fornece, portanto, os subsídios para o reconhecimento do bem e da sua importância no contexto.

As etapas deste processo incluem a coleta, registro dos dados e o seu armazenamento para possíveis análises e organizações segundo os objetivos do trabalho e de quem utilizará a informação.

As informações servem de base não só para fase inicial de inventário, de atribuição de valor, de tombamento, de registro do bem e da sua história como também para a estruturação de um plano de conservação, de intervenções e de gerenciamento.

A documentação vem sendo destacada já há anos como uma etapa importante da preservação. Mencionada por vários teóricos da Restauração já no século XIX, sua importância foi ressaltada também no século XX nas várias Cartas Patrimoniais e, principalmente, nos documentos propagados nos últimos anos em função da crescente inserção de novas tecnologias no campo da conservação.

A Carta de Atenas de 1931, sobre Restauração de Monumentos Históricos, já antes aqui mencionada, destaca também o valor da documentação internacional.

A Carta de Veneza ${ }^{46}$ para a Conservação e Restauração de Monumentos e Sítios, publicada em 1964, menciona no item relativo à publicação que a documentação deve existir em trabalhos de preservação, restauração e escavação e ela deve ser constituída de relatórios analíticos e críticos, desenhos e fotografias do processo, cujos registros devem permanecer na instituição pública responsável e acessível a pesquisadores e até mesmo serem publicados.

$\mathrm{Na}$ realidade as cartas apontam a necessidade da existência e de se fazer a documentação, porém, não citam a forma de fazê-la, e também não especificam a forma de apresentação dessas informações, o que acaba ficando a critério das respectivas nações.

Essas informações sobre os registros e a sua forma de apresentação, na nossa realidade, podem variar de acordo com a instituição, municipal, estadual,

\footnotetext{
${ }^{46}$ Artigo 16": "PUBLICATION: "In all works of preservation, restoration or excavation, there should always be precise documentation in the form of analytical and critical reports, illustrated with drawings and photographs. Every stage of the work of clearing, consolidation, rearrangement and integration, as well as technical and formal features identified during the course of the work, should be included. This record should be placed in the archives of a public institution and made available to research workers. It is recommend that the report should be published."
} 
federal e até mesmo de acordo com a firma ou profissional que executa a obra e/ou é responsável pelos registros do projeto e do processo de restauração da obra.

Existem várias cartas que também se referem ao processo de documentação e sua importância aplicada as diferentes áreas e especificidades dos bens que foram, ao longo dos anos, incorporados como patrimônio.

A carta de Burra 1999, em seu artigo 23ำ menciona que qualquer intervenção prevista deve ser precedida de estudos e dados disponíveis, materiais documentais e outros. Devem ser elaborados também pelos profissionais os documentos que perpetuem as informações sobre o objeto em estudo.

O artigo 25ำ menciona que qualquer ação sobre um objeto deve ser acompanhada por uma proposta escrita que justifique a decisão tomada, com provas documentais (fotos, desenhos, amostras, etc).

Atualmente, os novos recursos tecnológicos do setor de informação vêm contribuindo para a estruturação de novas formas de registro documental, monitoramento, gerenciamento e atuação, cujo ganho pode ser inestimável se aplicado à preservação do patrimônio cultural.

A adoção das novas tecnologias $\mathrm{SIG}^{47}$, Fotogrametria, Fotografia Retificada, Laser Scanning, CAD, Maquete Virtual, etc, como ferramenta de registro, conhecimento, investigação, análise e pesquisa do patrimônio cultural, possibilitam uma agilidade maior na manipulação de dados e no gerenciamento de informações que possam evitar eventuais perdas causadas pela crescente expansão urbana e especulação imobiliária nas grandes cidades, ou mesmo minimizar perdas causadas pela degradação ou danos de diferentes naturezas.

Estes novos recursos têm sido aqui empregados no setor privado, em diferentes áreas e também vem gradativamente se incorporando ao setor público com experiências voltadas, a princípio, para questões mais abrangentes do território, direcionadas à cidade, ao planejamento urbano e, paulatinamente, sendo empregados na área de preservação de patrimônio e documentação do bem imóvel, móvel e integrado.

\footnotetext{
47 O SIG sistema de informação geográfica (ou GIS geographic Information System) trabalha com base em dois modelos: o modelo raster ou matricial e o modelo vectorial de informações espaciais. $O$ primeiro trabalha as qualidades do espaço através do uso de celulas cujo tamanho se relaciona com a resolução e o segundo trabalha a localização no espaço através de coordenadas.
} 
Apesar dos investimentos iniciais exigidos, em termos financeiros e de recursos humanos e tecnológicos e, posteriormente, na manutenção deste sistema, a documentação tem sido um campo de atuação crescente, pois permite uma economia de tempo e custo e representa um elemento chave de convergência e articulação de informações em várias áreas que envolvem o trabalho de conservação.

Os níveis de precisão da documentação bem como os equipamentos necessários para a sua execução dependem dos objetivos do trabalho, dos recursos disponíveis e das necessidades.

A necessidade crescente de uma normalização ${ }^{48}$ na área para os registros e uso de símbolos que até então ficaram a critério de profissionais ou firmas de execução de trabalhos de restauração, já é tema de discussões internacionais, ${ }^{49}$ há alguns anos, e de cursos de formação de especialistas na área desenvolvidos pelo International Centre for the Study of the Preservation and Restoration of Cultural Property - ICCROM. ${ }^{50}$

Deve-se lembrar que, apesar do processo de documentação já ser parte integrante de trabalhos de restauração desde o século XIX uma ênfase maior tem sido dada a área nas últimas duas décadas na comunidade internacional, todavia, com outro enfoque, que é o resultado de pesquisas e da constatação da insuficiência de documentação realizada na conservação do patrimônio em diferentes países, dos avanços tecnológicos, das necessidades geradas pelos inúmeros conflitos entre povos, bem como da perda do patrimônio e também da possibilidade da utilização da documentação em campos diversos envolvendo desenvolvimento e qualidade de vida.

\footnotetext{
${ }^{48}$ Normalização vem do verbo normalizar que já existe e é utilizado no sentido de estabelecer algo como normal, normatizar/normatização são termos que surgiram posteriormente e hoje já estão registrados no dicionário Aurélio na ultima versão. A ABNT utiliza e define normalização como "a atividade que estabelece, em relação a problemas existentes ou potenciais, prescrições destinadas à utilização comum e repetitiva com vistas à obtenção do grau ótimo de ordem em um dado contexto." "Na prática, a Normalização está presente na fabricação dos produtos, na transferência de tecnologia, na melhoria da qualidade de vida através de normas relativas à saúde, à segurança e à preservação do meio ambiente."

${ }^{49}$ O tema da documentação tem sido trabalhado a mais de trinta anos como menciona Kate Clark em RECORDIM, mas nas ultimas décadas tem se intensificado os trabalhos com uma nova abordagem e com auxilio de novas tecnologias. Em 2002 peritos de diferentes países se reuniram no Instituto Getty de Conservação em Los Angeles, para discussão do tema.

${ }^{50}$ De 2003 a 2009 quatro cursos foram realizados no ICCROM três deles realizados em parceria com - Getty Conservation Institute $(\mathrm{GCl})$, sobre registro de patrimônio arquitetônico, documentação, inventário e sistema de informação para conservação (ARIS).
} 
Embora vários esforços tenham sido realizados nesse sentido na nossa realidade brasileira, mais especificamente a paulistana, eles ainda aparecem como exemplos pontuais de casos.

Nas instituições de preservação como CONDEPHAAT, CONPRESP existem alguns informativos com requerimentos ${ }^{51}$ e especificação da documentação oficial para autuação de processos e de solicitação de execução de processo de restauração do patrimônio imóvel. Porém, não existe uma padronização da apresentação destes e nem sempre a documentação apresentada engloba todos os itens, sendo, aos poucos, após a análise dos técnicos, solicitado aos interessados alguns itens que ficaram faltando, o que gera um atraso na avaliação dos projetos e liberação da execução da obra.

Através das consultas realizadas nas instituições, como parte da pesquisa de campo, surgiram novas evidências sobre as informações relativas à documentação das obras e determinados aspectos foram observados.

Foram considerados os registros de documentação existentes nas instituições sobre as obras que se encontravam tombadas nas respectivas instâncias federal, estadual e municipal.

O gráfico revela a predominância do tipo de documentação existente nas instituições. Apesar de não apresentar nenhuma edificação tombada com arte mural a nível federal (IPHAN) em SP, optou-se por manter a referência da instituição no gráfico de forma a ilustrar a situação.

\footnotetext{
${ }^{51}$ Os requerimentos podem ser consultados na página do CONDEPHAAT na internet. Disponível em: $<$ http://www.cultura.sp.gov.br/portal/site/SEC/menuitem.fe8f17d002247c2c53bbcfeae2308ca0/?vgnext oid=963c6ed1306b0210VgnVCM1000002e03c80aRCRD>. Acesso em: 19 jan. 2011.

No Conpresp a documentação exigida pode ser consultada na internet em página institucional. Disponível em: <http://www.prefeitura.sp.gov.br/cidade/secretarias/cultura/conpresp/formulario/>. A documentação exigida para projetos de restauro está disponível em: $<$ http://www.prefeitura.sp.gov.br/cidade/upload/Projetos\%20de\%20Restauro 1203349262.pdf>. Acesso em: 19 jan.2011.
} 


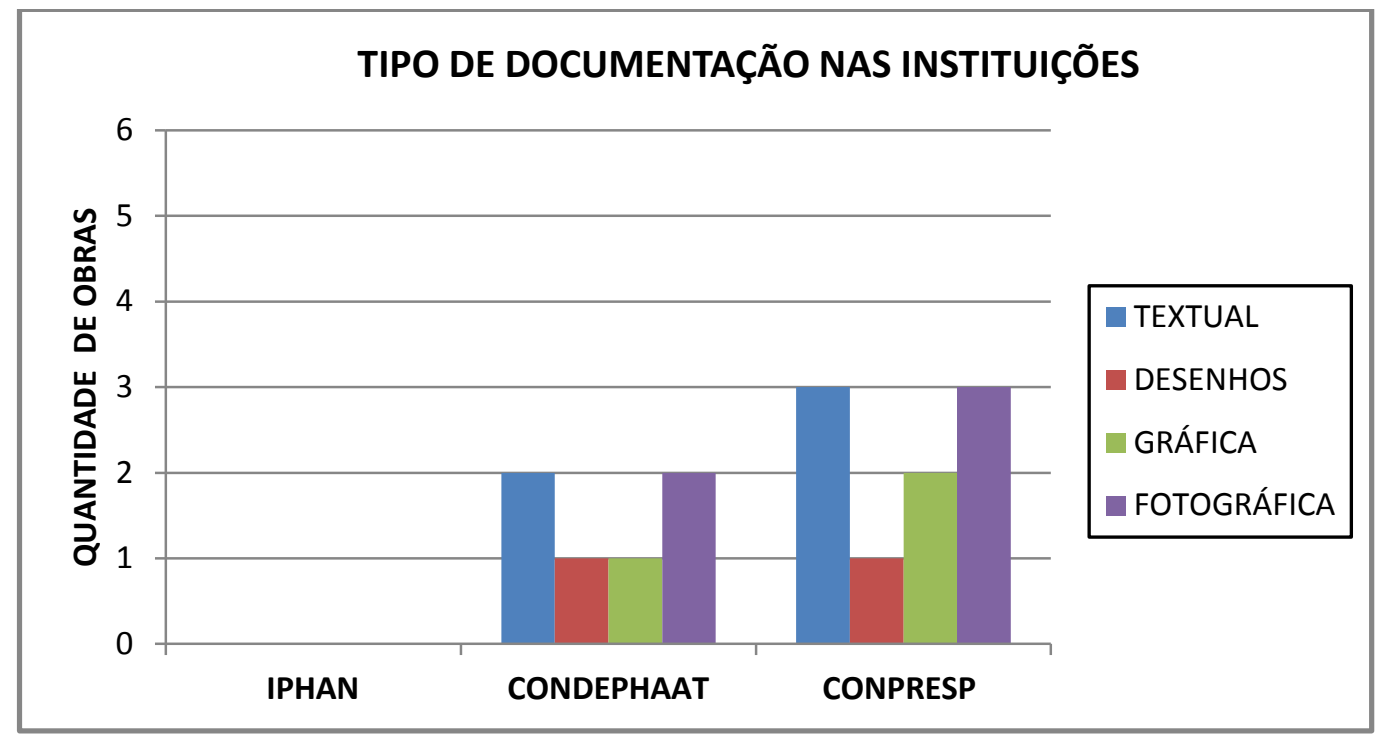

Gráfico 1 - Tipo de Documentação nas Instituições

Em consulta realizada para checar a existência de material relativo a obras murais que sofreram intervenções em edificações tombadas a nível estadual e municipal, pode-se constatar que as edificações tombadas eram em número extremamente reduzido um total de três obras ${ }^{52}$. Somente as obras murais que estavam em edificações tombadas ou que em processo de tombamento pelo município representavam um número um pouco maior. No entanto, nem todas apresentavam material relativo às intervenções.

Além disso, constatou-se que do material disponível nas instituições tinha como registro predominante a documentação textual, e fotográfica (em alguns casos já em formato das novas mídias como o $C D$ ), algumas vezes a presença da documentação gráfica (de plantas) como auxiliar na localização da obra mural no espaço arquitetônico.

Não foram encontrados materiais como desenhos relativos ao estado de conservação ou mapeamento de danos, nem mesmo registros de análises científicas

\footnotetext{
${ }^{52}$ As obras tombadas nas duas instâncias (Estado e Município) são: Capela do Hospital das Clínicas, Edifício Louveira, Capela Cristo Operário.

Existem outras obras que estão sobre proteção legal municipal, através de tombamento realizado pelo CONPRESP: a Capela Cristo Operário e suas obras de arte, tombamento através da resolução 11/2004; Aeroporto de Congonhas, onde se localiza o mural de Clovis Graciano e Di Cavalcant no Pavilhão das Autoridades, abertura de processo de tombamento resolução no 24/2004i; Edifício Louveira, onde se encontra o mural de Francisco Rebolo no hall de entrada, tombamento através da resolução 09/2002, que não menciona, porém, a existência do mural; Capela do Hospital das Clínicas, obra mural de Fulvio Pennacchi, tombamento das obras de arte através da resolução 05/1991 tombamento "ex officio"; Teatro João Caetano, mural de Clovis Graciano, tombado através da resolução no 29/92: Antigo Edifício do Jornal O Estado de São Paulo, Hotel Jaraguá, etc.
} 
realizadas sobre a constituição material da obra, sobre a técnica, ou para embasar efeitos gerados por processos de degradação.

Outro aspecto constatado é a inexistência de conjuntos iguais de materiais de documentação relativo à mesma obra tombada nas duas instâncias (Estadual e Municipal), nas respectivas instituições. ${ }^{53} \mathrm{O}$ que pode gerar interpretações diversas se a documentação completa se encontra em um único local e a consulta for feita somente no outro.

A apresentação do material de documentação, como já dito, fica a critério do próprio profissional que executa a obra, sem que seja necessário seguir qualquer padrão de registro institucional, que na realidade para esse tipo de bem cultural, integrado, a arte mural, não existe.

Além disso, em contato com os clientes, proprietários, ou responsáveis pelos imóveis onde as obras murais tinham sido executadas, verificou-se também que eles não tinham registros documentais da encomenda e da realização da obra e nem mesmo das intervenções nela realizadas. A autora em um determinado caso acabou fornecendo, a pedido da instituição proprietária, o material que havia conseguido no órgão de preservação. A constatação dessa realidade pode configurar uma prática comum que demonstra que os relatórios de trabalho só são fornecidos as instituições e não necessariamente ao cliente, ou a quem contratou o serviço conforme sugerido em documentos.

A dispersão e/ou a falta das informações prejudica o próprio resgate da história da obra não só para o proprietário do local onde o mural está inserido, mas também para todos aqueles que tenham interesse neste tipo de arte.

Além disso, torna-se necessário uma padronização dessa documentação que pode ser conseguida com a criação ou adoção de uma base de dados pela instituição, bem como de glossários definindo conceitos, a terminologia utilizada, as legendas, etc, que permitam ao técnico e a qualquer membro do corpo institucional a fácil compreensão dos termos utilizados evitando, assim, que possam ocorrer divergências entre a linguagem e o entendimento de profissionais da área prática de execução (conservadores-restauradores), e os da área institucional.

\footnotetext{
${ }^{53}$ Segundo informações obtidas nas instituições de preservação o tombamento em uma instância não exime o proprietário, ou interessado na execução do projeto, de ter que abrir um processo também na outra instância. Portanto, ambas deveriam ter um processo aberto e material de documentação, mas como as exigências não são padronizadas para a arte mural ou bens integrados e são as vezes diferentes para os bens imóveis, o material existente varia entre as instituições.
} 
A utilização de bases de registros para documentação, principalmente da arte mural, recebe por parte da comunidade técnica e científica no exterior um tratamento especial e foi tema de encontros onde as informações relativas à atuação de diferentes países nesta prática puderam ser compartilhadas e as experiências em documentação, trocadas, refletidas e avaliadas.

Dentre esses encontros destacam-se o GRADOC, Graphic Documentation Systems in Mural Painting Conservation, Seminário de Pesquisa ocorrido em, Roma em 16-20 November 1999 no ICCROM. No âmbito mais geral do patrimônio cultural, destacam-se as iniciativas do RecorDim, Recording, Documentation and Information Management Initiative, do Getty Conservation Institute desenvolvido entre 20032007 em parceria com os cursos do ICCROM, Architectural Records, Inventories and Information Systems (ARIS).

Algumas experiências de documentação com utilização de recursos gráficos tem sido também empregadas em âmbito geral do nosso patrimônio cultural, não só na cidade de São Paulo, mas também no interior do estado. Essas experiências, bem como aquelas realizadas em São Paulo foram divulgadas no Seminário Computação Gráfica: pesquisas e projetos rumo à Educação Patrimonial realizado de 4 a 6 de novembro em 2008, na sede da Secretaria Municipal de Cultura em São Paulo onde se reuniram profissionais que trabalham na área de documentação em São Paulo e também profissionais de vários outros estados. ${ }^{54}$

Uma outra referência de registro documental que inclui os bens integrados é a recente proposta do IPHAN de uma base de dados, divulgada em dezembro de 2009, que inclui os bens integrados e também a arquitetura moderna.

Esta base de dados organizada como nome de Sistema Integrado de Conhecimento e Gestão - SICG ${ }^{55}$ é um instrumento desenvolvido para integrar os dados sobre o patrimônio cultural, com foco nos bens de natureza material, reunindo em uma base única informações sobre cidades históricas, bens móveis e integrados,

\footnotetext{
${ }^{54}$ Alguns trabalhos de autores palestrantes do Seminário referem-se à documentação do patrimônio arquitetônico moderno, mas não parecem incluir a documentação da arte mural inserida nas edificações mencionadas em seus respectivos sites de divulgação, com exceção do trabalho desenvolvido na Universidade de São Paulo, que é um trabalho pontual, especifico e não configura uma base de dados de todo o patrimônio. Programa do Seminário disponível em:

$<$ http://www.arquiamigos.org.br/seminario3d/index.html\#topo $>$. Acesso: 20 out. 2010.

55 Sistema Integrado de Conhecimento e Gestão SICG, base de dados do IPHAN, com informações disponíveis em:

$<$ http://portal.iphan.gov.br/portal/montarPaginaSecao.do?retorno=paginalphan\&sigla=Documento\&id= 14897>. Acesso em: 20 out. 2010.
} 
edificações, paisagens, arqueologia, patrimônio ferroviário e outras ocorrências do patrimônio cultural do Brasil.

O sistema foi desenvolvido com três módulos, Conhecimento, Gestão e Cadastro e em cada um deles existem fichas de preenchimento com as respectivas informações sobre o patrimônio cultural.

Dentre as fichas de cadastro desenvolvidas para registro de patrimônio, existem opções para bens de diferentes naturezas, sendo os integrados incluídos na ficha SICG FM305 ou SICG FM303. A documentação do patrimônio moderno tem a ficha SICG FM301 como referência.

Em recente ata da reunião do II Encontro do Comitê Científico de Arquitetura do Século XX na América, realizado em Brasília em dez, de 2010 foi sugerido que se averiguasse a ficha de inventário que é usada pelo Docomomo Brasil e a existência de uma ficha desenvolvida pelo IPHAN. ${ }^{56}$

Portanto, a estruturação de bases sólidas de registro e documentação de bens imóveis juntamente com os bens integrados representa um avanço significativo para uma prática integrada entre arquitetura e bens integrados e também para o monitoramento, o gerenciamento e a avaliação de medidas de conservação a serem implantadas.

As diferentes possibilidades de registro documental e o desenvolvimento de diferentes bancos de dados por instituições distintas só vem comprovar a necessidade crescente de uma padronização e a adoção de um sistema que permita um trabalho conjunto integrando diferentes fontes de informação.

Além disso, a preservação da arte mural não deve ser uma prática desvinculada de programas de conservação integrada, com a conservação e restauração do imóvel, pois se sabe que geralmente a restauração é realizada, de forma pontual e isolada, sem relação com programas de conservação e monitoramento, o que pode levar ao desperdício de recursos financeiros investidos em obras.

A falta de uma legislação específica de tombamento da arte mural, o que para muitos não é considerado necessário, pois a arte mural é um bem integrado, acaba colocando-a numa situação de risco e relegando-a um mero elemento interno, que nem sempre recebe as devidas atenções e cuidados que a obra de arte deveria ter.

\footnotetext{
${ }^{56}$ Ata do Encontro disponível em:<http://www.icomos.org.br/004 002.html>. Acesso em: 03 abr. 2011.
} 


\subsection{A Prática do Setor Privado}

\subsubsection{Metodologia e Pesquisa de Campo}

Como parte da pesquisa da tese foi realizado um trabalho de campo, a fim de coletar dados e informações de diferentes naturezas que, em sua grande maioria, estavam dispersos, em instituições responsáveis pela preservação, com os proprietários e com os profissionais de conservação e restauração que atuam na área, para que os dados e informações permitissem a confirmação e a complementação de informações para a realização de uma análise e se pudesse delinear um quadro da situação desta área de preservação da arte mural no contexto da cidade de São Paulo.

Nas instituições foram observados itens relacionados ao material de documentação existente referente aos projetos e intervenções de conservação e restauração, considerando os requisitos exigidos, a forma de apresentação destes, o acesso a informação, etc.

Com relação ao material existentes nas instituições, algumas informações já foram relatadas no capítulo anterior e lacunas foram evidenciadas, não só de itens faltantes, mas de registros diferenciados o que poderia ser resolvido com a adoção de uma linguagem padronizada.

Aos profissionais atuantes na área foi encaminhando um questionário elaborado com a intenção de que fosse preenchido por eles e devolvido posteriormente a autora. Através dele se confirmou e/ou complementou as informações já obtidas de outras fontes.

O questionário ${ }^{57}$ foi estruturado com perguntas de ordem geral sobre as atividades empresariais e com outras informações mais específicas, que detalhassem algumas atividades relacionadas com a prática e, que pudessem contribuir para a análise a ser realizada. Vários itens considerados como informações mais técnicas e possíveis de serem avaliados e pesquisados tiveram que ser excluídos, já que os dados seriam trabalhados de forma estatística e, também, para assegurar que o preenchimento não tomasse muito tempo dos profissionais, permitindo assim a colaboração e um retorno para a pesquisadora.

\footnotetext{
${ }^{57}$ Ver questionário desenvolvido para a pesquisa e enviado aos profissionais, no Anexo I.
} 
O questionário foi encaminhado para um grupo de dez empresas selecionadas que apresentam em seus quadros de profissionais pessoas que atuam na área de conservação e restauração de murais. Existem, contudo, outras empresas e profissionais que não foram incluídos na pesquisa, pois atuam mais no interior do estado. O critério de seleção dos profissionais ou das empresas partiu, a princípio, da escolha daqueles profissionais que tinham uma atuação mais significativa e haviam feito intervenções em murais na cidade de São Paulo. Neste caso, tendo em vista que o grupo que atua na área é relativamente pequeno, não foi realizado um recorte de empresas que restringisse a atuação somente nas obras dos artistas estudados, mas foram enviados os questionários para todas as empresas e profissionais selecionados que tinham experiência na área.

A colaboração dos profissionais no preenchimento foi bastante restrita das dez empresas selecionadas somente três responderam o questionário. Porém, isso não acarretou em um prejuízo maior das informações coletadas, já que o trabalho foi realizado, também, em várias outras fontes e apenas serviu como confirmação das mesmas.

A análise destacou os aspectos primordiais da estruturação desta prática evidenciando as contradições ou não dos itens problematizados decorrentes do empirismo na prática. Os itens, como anteriormente mencionados, incluem a escassez e/ou inadequada documentação e registro das obras, cuja situação já foi previamente relatada no capítulo anterior, a escassez de definição da terminologia utilizada, a prática desvinculada de programas de conservação integrados, a formação profissional, etc.

A proposta da avaliação destes aspectos permitiu configurar o quadro de atuação prática dos profissionais da área para embasar futuras recomendações e/ou diretrizes a serem desenvolvidas que possam colaborar para a uma política de preservação.

Os resultados da pesquisa podem contribuir para um mapeamento da situação em São Paulo, para o avanço do conhecimento nesta área, ainda bastante escasso, além de reiterar que somente com o desenvolvimento de práticas integradas de preservação é que podemos conseguir de forma concreta a preservação do patrimônio cultural. 
A aplicação de uma metodologia de trabalho relacionada às atividades de conservação visa contribuir para o acompanhamento, transparência, permanência e seqüência dos investimentos realizados nas obras, assim como, para despertar de uma nova postura e cultura quer do corpo técnico institucional quer do cidadão, que usufrui do espaço onde ela se encontra.

\subsubsection{Agentes Executores}

O termo agentes executores é adotado neste caso para se referir aqueles profissionas envolvidos na execução prática da conservação e restauração das obras murais e não para indicar aqueles que estruturam e coordenam políticas de preservação, geralmente, membros de um corpo institucional de qualquer uma das instâncias (Municipal, Estadual, ou Federal).

Esses agentes atuam como profissionais liberais, prestadores de serviços ou vinculados a empresas e ateliês que trabalham neste ramo. Através do levantamento realizado foi possível traçar um perfil do profissional que atuou e atua neste ramo de atividade.

A fim de melhor compreender a evolução da atuação desses profissionais na área, optou-se pela realização de uma linha cronológica dividida em períodos correspondentes a décadas, facilitando, assim, a análise como um todo.

A divisão foi realizada visando um possível reconhecimento de progressos evolutivos desses profissionais, nas diferentes décadas e, não propriamente de uma divisão segundo um padrão de evolução da arte mural relacionado a seus estilos ou técnicas.

Vários são os profissionais que já se envolveram com a conservação da arte mural, muitos deles eram oriundos de ofícios artesanais, como os 'pintores de parede', da área artística como os próprios artistas plásticos ou seus colegas, os restauradores de pintura, os restauradores especializados em pintura mural e mesmo profissionais da área de arquitetura, com eventuais cursos na área, ou apenas com uma experiência prática. 
Nos gráficos a seguir é possivel visualizar a atuação dos diferentes profissionais da área num período de quarenta anos desde a década de 1970 até nosso dias.

Apesar da constatação das intervenções nas obras nos respectivos períodos, registrados no gráfico, não se pode delimitar com tanta rigidez a interrupção total da atuação de profissionais nessa prática. Eles continuam atuando simultaneamente, porém, é possível considerar que existe uma predominância das atividades desenvolvidas, por um ou outro tipo de profissional com o passar dos anos, principalmente em função de aspectos relacionados a alteração na formação dos mesmos e o próprio distanciamento do tempo da execução da obra, que passa a exigir a intervenção em épocas posteriores, quando alguns deles não mais estavam atuando.

No início do século $X X$ a função de intervenção em obras se restringia aos pintores de parede cuja habilidade com a técnica parecia ser mais indicada para tal finalidade de "recuperação", ${ }^{58}$ principalmente em pinturas decorativas/artísticas, tradição de pintura por eles introduzida no século XIX. Os pintores de parede eram geralmente chamados para realizar pinturas lisas, decorativas e/ou artísticas e o "retoque ou restauração" 59 daquelas pinturas que se encontravam deterioradas.

A escassez deste tipo de trabalho e do profissional, o 'pintor de parede' ou 'pintor decorador, a partir de meados do século XX, transferiu paulatinamente esta atividade de "restauração" para os artistas. Até os anos de 1960 artistas como Fulvio Pennachi e Clovis Graciano ainda atuavam na realização de suas respectivas produções de obras murais.

Na década de 1970 ocorreu uma demanda aos próprios artistas ou a seus colegas pela realização de trabalhos de recuperação de algumas obras, muitas vezes pelo do fato do próprio artista ter executado as obras e ainda estar vivo para poder "recuperá-las".

\footnotetext{
${ }^{58}$ O termo "recuperação" foi mantido entre aspas, pois indica uma intervenção que não representa exatamente uma recuperação, mas está associada a possíveis intervenções mais abrangentes, incluindo repintura.

${ }^{59}$ O termo "restauração" foi colocado entre aspas, pois, tem sido utilizado de forma equivocada por profissionais que não tem formação na área e, portanto, não conhecem exatamente o conceito, mas utilizam o termo com a intenção de destacar uma intervenção de correção, embelezamento, conserto, repintura de algo que se encontra deteriorado ou fora dos padrões convencionais e estéticos vigentes, sem, contudo, respeitarem os critérios internacionais estabelecidos para esse tipo de intervenção.
} 


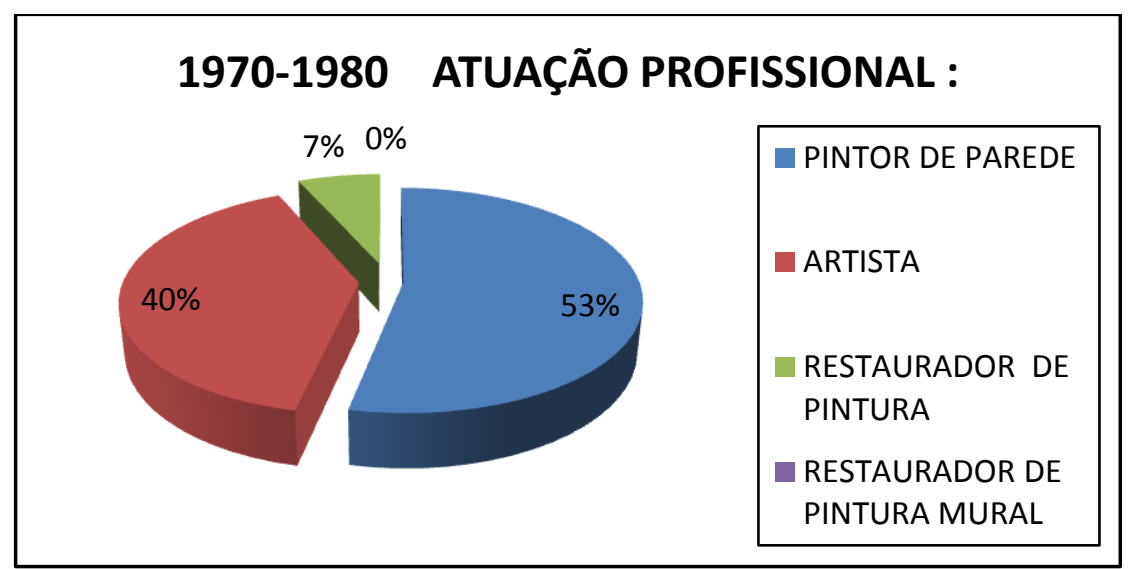

Gráfico 2 - Atuação Profissional de 1970-1980

Neste contexto destacam-se dois exemplos interessantes o do artista Fulvio Pennacchi, chamado várias vezes para fazer retoques em suas obras em função da remoção delas de um local para outro ${ }^{60}$ e também a intervenção realizada por um artista na obra de Clovis Graciano no Teatro João Caetano na Vila Clementino. ${ }^{61}$

Em fins da década de 1970 e início da década de 1980 foram introduzidos os conceitos de restauração e difundidos no meio da preservação, através do aperfeiçoamento de profissionais atuantes na área. Esssa década marca aqui o começo da atuação de alguns profissinais da área de restauração em instituições e de algumas atuações no mercado.

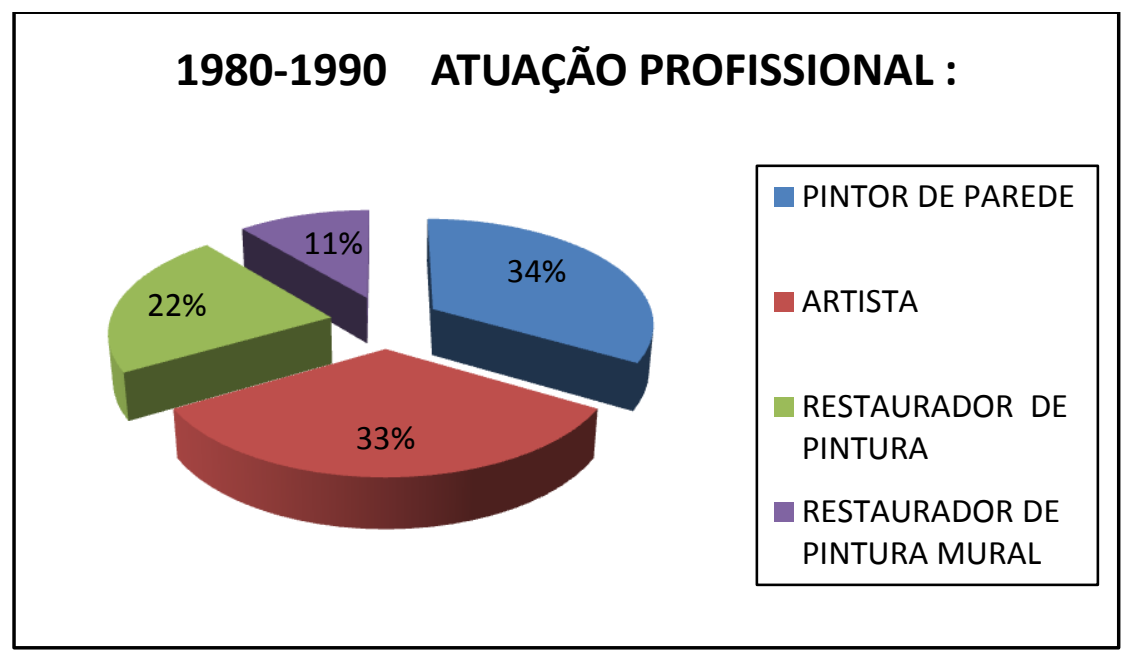

Gráfico 3 - Atuação Profissional de 1980-1990

60 Depoimento dado para a autora pela filha do pintor, Giovanna Pennacchi, em 2006, e pelo engenheiro Paulo Sproviero, responsável pela remoção da maioria das obras deste artista de residências ou empresas para outros locais.

${ }^{61}$ A intervenção no Teatro João Caetano realizada por um artista de nome ícaro, em 1978, está datada na obra e teve a autorização do autor Clovis Graciano, segundo consta em relatório de Euler Sandeville Junior sobre os Teatros Distritais da PMSP de 1985/86. 
Em fins dos anos 80 e já na década subsequente de 1990 houve um crescimento da demanda por esse tipo de atividade de conservação e restauração, a princípio mais voltada para os bens móveis, o que gerou um aumento de profissionais na área. Profissionais esses, que nem sempre eram qualificados ou recebiam uma formação teórica, mas eram interessados na prática imediata e, portanto, atuantes em diversos seguimentos sem restrições, já que vários se intitulavam 'auto didatas'.

Paralelamente a esses 'auto didatas', crescia o número de formandos de nível universitário em artes e arquitetura que passaram a se interessar pelo assunto e a buscar cursos de aperfeiçoamento e especialização na área, aqui e no exterior. Houve também um deslocamento desses profissionais para a atuação com os bens integrados a medida que a demanda ia crescendo.

É todavia em fins da década de 1990 e início de década seguinte de 2000 que se terá uma atuação mais intensa de profissionais especializados em murais, quer no âmbito institucional, de pesquisa e ensino, quer no mercado de trabalho executando obras em diferentes locais.

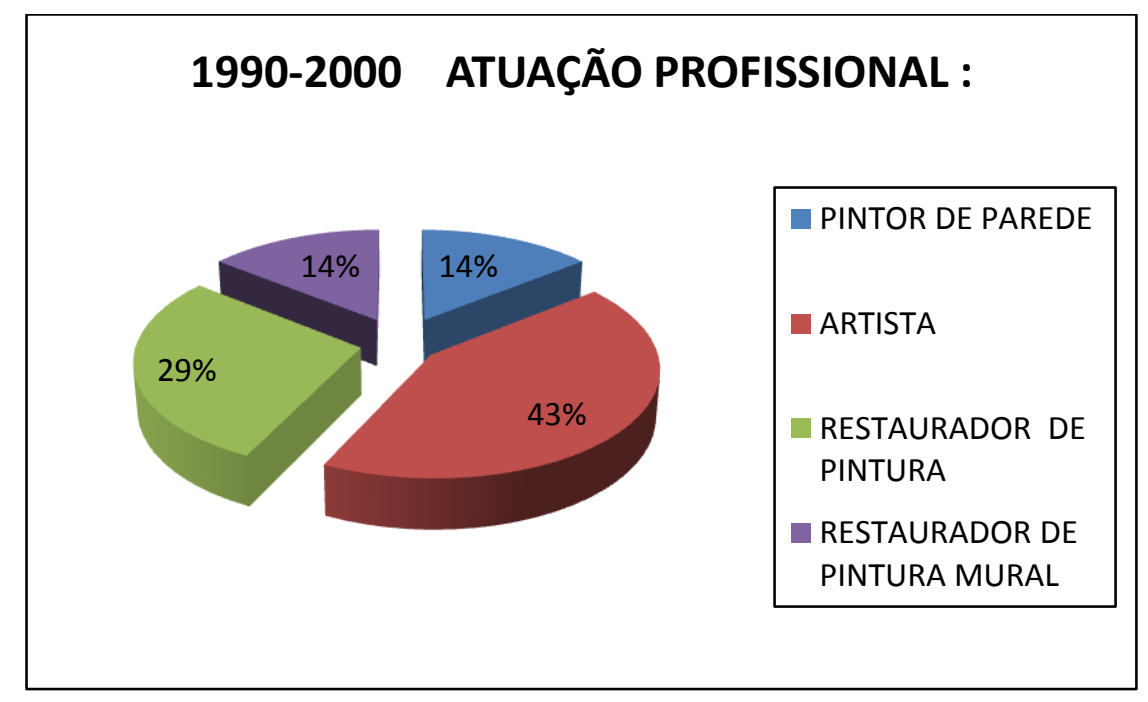

Gráfico 4 - Atuação Profissional de 1990-2000 


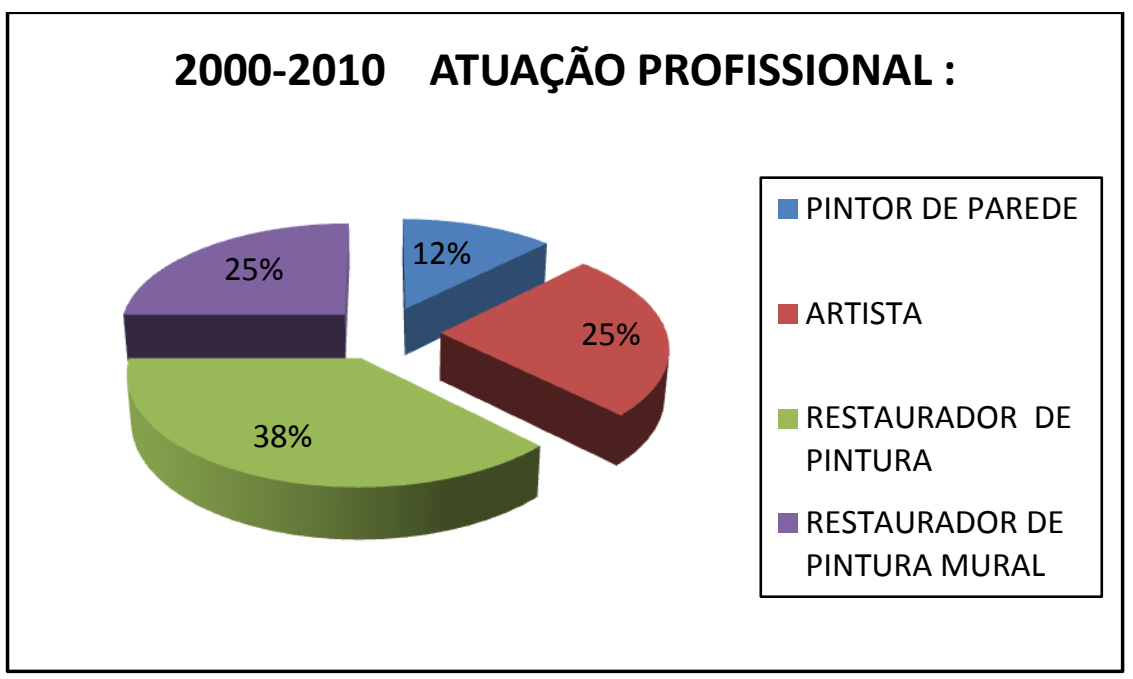

Gráfico 5 - Atuação Profissional de 2000-2010

Essa intensa atuação em 2000 a 2010 tem ocorrido por diversos motivos que vão da crescente demolição de residências e prédios onde as obras se encontravam, destruição iniciada já na década de 80 , por motivos de desgastes das obras em função do tempo e descuidos de conservação e manutenção, por reformas nas edificações onde se encontram as obras, pelo crescente incentivo fiscal na preservação de bens e também pelo apoio dado por programas de empresas que tem investido na cultura e na preservação.

Ao longo dos anos houve um crescimento e uma busca por formação na área de conservação-restauração de bens móveis e integrados. Percebe-se, então, uma mudança de perfil do profissional atuante nesta área durante esses anos de prática. Isso não significa que houve um aumento substancial no número de profissionais especializados em murais, mas que eles passaram a atuar já com uma formação teórica-conceitual diferente de outros que exercem a atividade sem qualquer formação, como veremos no estudo de casos adiante.

Os trabalhos de conservação-restauração só são realizados mediante a solicitação e ou encomenda de alguém interessado. Geralmente as solicitações são feitas pelos próprios proprietários dos imóveis, pelos parentes dos artistas, cujo interesse é a preservação da obra do mesmos, pelos orgãos competentes (através das licitações ou por dispensa de licitação no caso de notória especialização) e pela comunidade diretamente envolvida com o bem. 


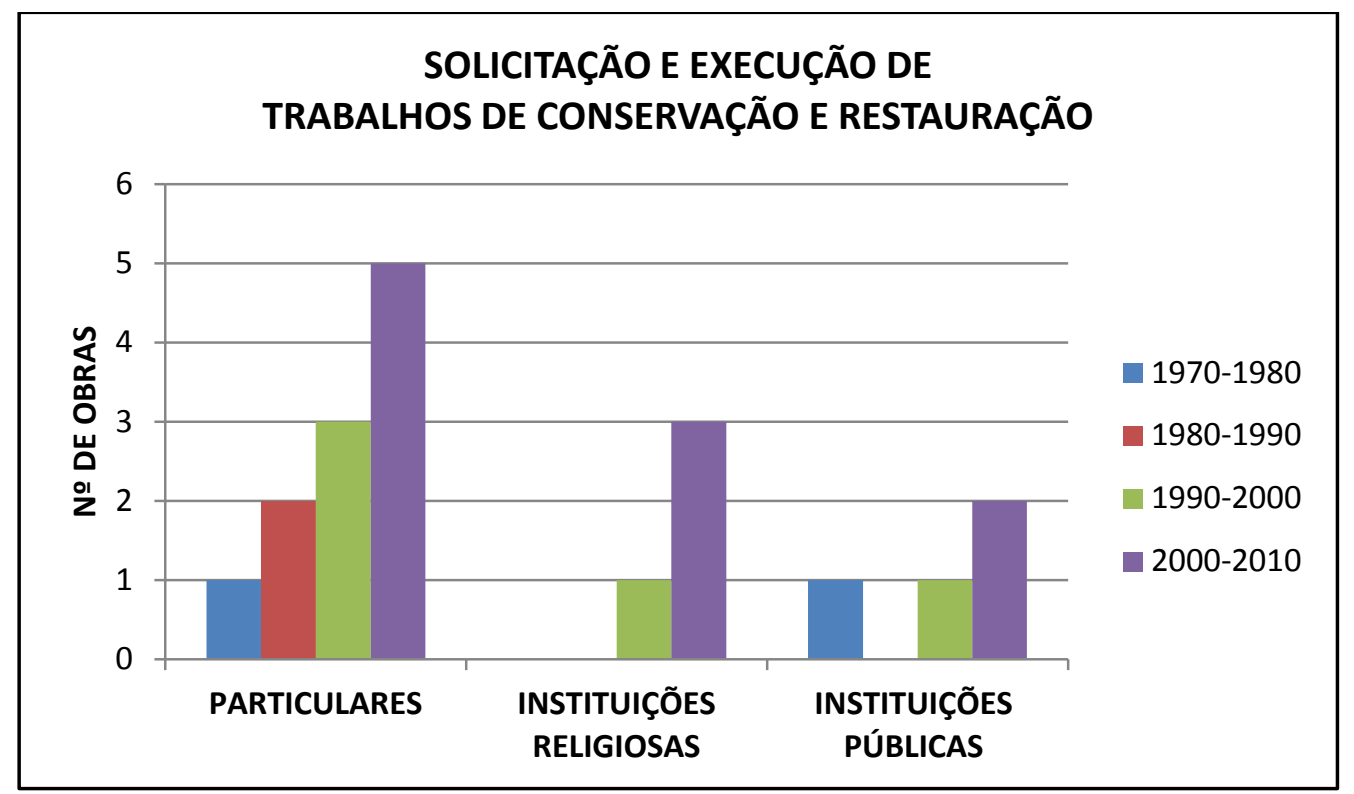

Grafico 6 - Solicitação e Execução de Trabalhos de Conservação e Restauração

É visível no gráfico 6 que as encomendas de trabalhos de conservaçãorestauração estão concentradas nos particulares, ou seja, a maioria das solicitações de trabalho feita aos restauradores são realizadas por iniciativas de particulares, mais do que por parte das instituições, quer sejam elas religiosas ou públicas, pois muitas das edificações onde as obras murais se encontram não são tombadas, o que provavelmente contribui para o fato de haver essa concentração de solicitações nos particulares.

Essa realidade está sofrendo mudanças e, recentemente, tem aumentado o número de imóveis do século XX que passaram a ter proteção legal pelo Conselho Municipal de Preservação do Patrimônio Histórico, Cultural e Ambiental da Cidade de São Paulo, o CONPRESP. ${ }^{62}$ Várias das edificações onde estão localizadas as obras murais, apesar de não serem tombadas já tiveram os seus processos de tombamento aberto, o que de certa forma as torna protegidas.

Um grande incentivo à preservação de obras da arquitetura moderna também tem sido dado pelo $\mathrm{DOCOMOMO}^{63}$ o que pode contribuir para a preservação deste tipo de bem integrado.

\footnotetext{
${ }^{62}$ As resoluções do Conpresp estão disponíveis em: $<$ http://www.prefeitura.sp.gov.br/cidade/secretarias/cultura/conpresp/legislacao/resolucoes/index.php? $\mathrm{p}=1137$ >. Acesso em: 15 abr. 2011.

${ }^{63}$ Criado em 1992 o DOCOMOMO Brasil tem representação em oito núcleos estaduais incluindo o Estado de São Paulo. Informações disponíveis em:

$<$ http://www.docomomo.org.br/oqueedocomomo.htm>. Acesso em: 15 abr. 2011.
} 


\subsubsection{Agentes Financiadores e Patrocinadores.}

Os elementos essenciais que fazem parte do processo de preservação especificamente das práticas de atuação são três: o contratante, o executor e o financiador. O primeiro, o contratante, pode ser o proprietário, os familiares do artista, a comunidade ou as instituições de preservaçãa ${ }^{64}$. O segundo, o agente executor, é o restaurador, que como já relatado pode ter diferentes formações ou mesmo só a experiência prática. $O$ terceiro, o agente financiador é aquele que fornece os recursos financeiros para a execução do projeto de conservação e restauração e pode ser desde um órgão público, através do processo de licitação ou de dispensa por notória especialização, uma pessoa jurídica, uma instituição ou empresa privada, a pessoa física, ou até mesmo grupos associados.

$\mathrm{O}$ investimento por parte dos financiadores em projetos desta natureza geralmente ocorre como forma de obtenção de isenção fiscal e/ou com intenção de divulgação da imagem da empresa associada a uma atividade incentivadora e divulgadora da preservação da cultura, que é hoje reconhecida pela sociedade e valorizada nos meios de comunicação.

\section{EXECUTOR}

\section{CONTRATANTE}

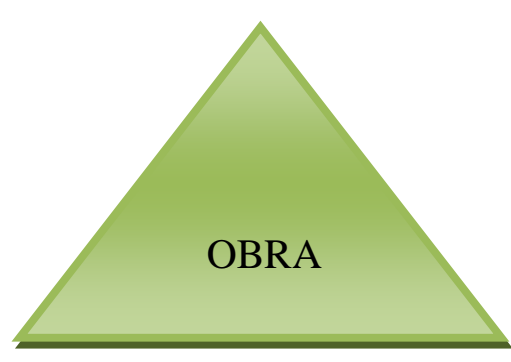

\section{FINANCIADOR}

Figura 4 - Elementos componentes das práticas de atuação.

Da década 1990 até os anos atuais um grande incentivo tem sido dado para a preservação dos bens móveis e integrados. Os programas foram a princípio iniciados por associações civis, como a VITAE, ${ }^{65}$ que através de projetos de cooperação e de parcerias, despertaram a atenção dos órgãos públicos para a

${ }^{64}$ O próprio contratante poder ser, as vezes, também financiador da obra de restauração.

${ }^{65}$ A VITAE foi uma associação civil sem fins lucrativos que apoiou projetos nas áreas de Cultura, Educação e Promoção Social e desenvolveu uma série de programas colaborando com instituições de preservação como: os programas de Apoio a Museus; o Programa de Inventário de Bens Móveis e Integrados; e o programa do Fundo de Formação para profissionais da área de preservação desenvolvidos desde 1992. 
atuação no setor. A VITAE foi responsável pelo apoio à realização de inventários de bens móveis e integrados em parceria com o IPHAN em diversos estados e pela realização de vários projetos de apoio a recuperação do patrimônio móvel, que tiveram grande de visibilidade e aceitação pela sociedade.

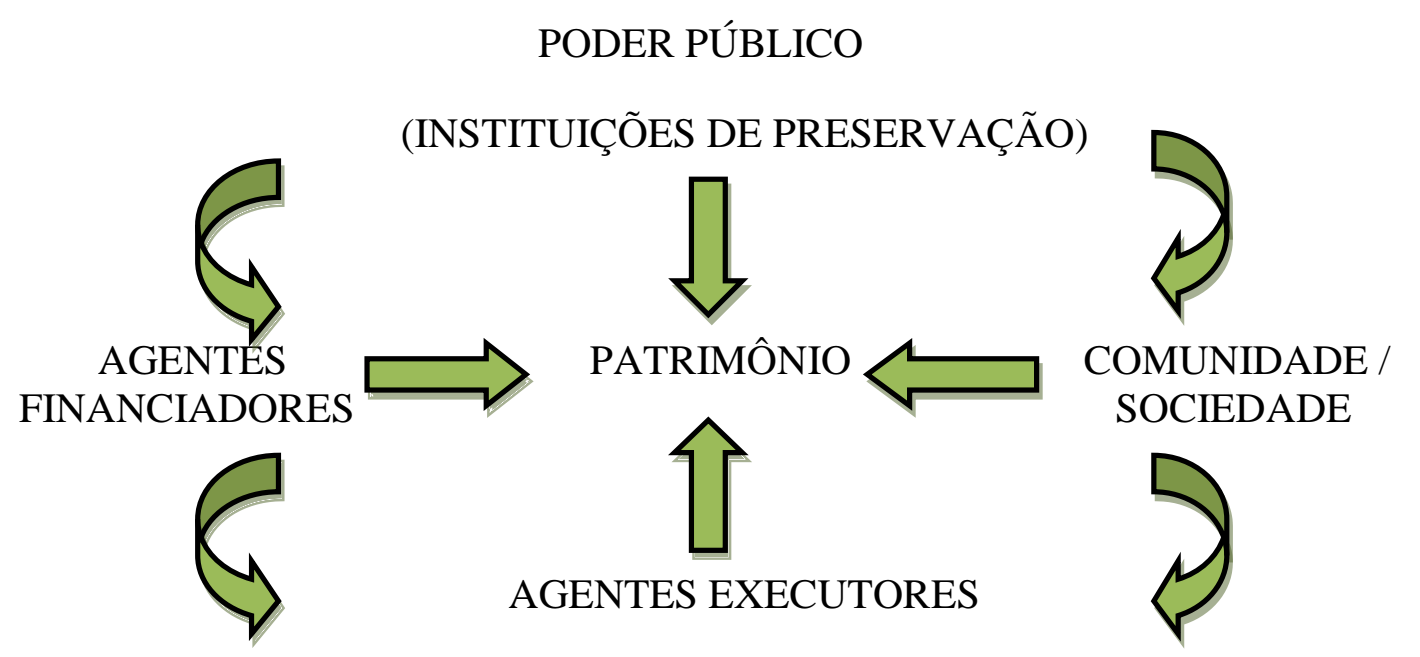

(CONSERVADORES-RESTAURADORES/ EMPRESAS DE RESTAURAÇÂO)

Figura 5 - Esquema das atividades práticas de conservação e restauração.

Outros mecanismos que também permitiram a ampliação de investimentos na área de preservação de bens e a aceleração das atividades de conservação e restauração, principalmente a partir da década de 1990, foram as leis de incentivo fiscal nas três instâncias.

A criação da Lei Rouanet no 8.313/91 a nível federal, que tem passado por alterações; a Lei Estadual ํo 8.819 que foi criada durante o governo de Fleury e vigorou de 1996 a 1998; a Lei no 12.268 de 20/02/06 instituiu o Programa de Ação Cultural (ProAC) de apoio a preservação e a difusão do patrimônio cultural material e imaterial do Estado, atuando através de duas formas de apoio, por meio da seleção pública de projetos, Editais e Concursos e por meio de Incentivo Fiscal (ICMS), apoio por meio de patrocínio(s) de contribuintes habilitados do ICMS a projetos previamente aprovados pela Secretaria de Estado da Cultura; e a Lei Mendonça, a Lei Municipal o 10.923 de 30 de dezembro de 1990, que está em vigor desde 1991 sendo que através do decreto no 46.595 de 05 de novembro de 2005 sofreu alterações. 
Além das leis de incentivos fiscais existem outros programas de fomento a cultura que abrangem a preservação do patrimônio e obras de conservação e restauração, como o Programa Petrobrás Cultural (PPC), ${ }^{66}$ que criado em 2003 tem ações de patrocínios da Petrobrás na área de Cultura. O PPC abrange três linhas de atuação: Produção e Difusão, Preservação e Memória, Formação e Educação para as artes e atende a diferentes segmentos culturais como Artes Cênicas, Artes Visuais, Cinema, Fotografia, Música, Literatura, Patrimônio e Artes Integradas e diversas linguagens artísticas.

O programa desenvolvido pelo BNDES $^{67}$ destina recursos financeiros para Preservação do Patrimônio Cultural Brasileiro com projetos desde 1997. Através do BNDES Procult - promove o apoio a preservação do patrimônio cultural brasileiro, a sua gestão e a articulação de projetos de restauração dos monumentos com projetos de revitalização de áreas urbanas que permitam obter resultados em benefício da população e do desenvolvimento local.

Outro programa também desenvolvido que envolve ações de preservação do patrimônio é o programa Monumenta, do Ministério da Cultura patrocinado pelo BID (Banco Interamericano de Desenvolvimento) com apoio da Unesco, cujos tramites para sua implantação foram estabelecidos 1995, mas foi iniciado efetivamente em 2000. O programa tem como finalidade atuar em cidades protegidas pelo Instituto do Patrimônio Histórico e Artístico Nacional (IPHAN) desenvolvendo programas de conservação e restauração de bens tombados, integrados com o desenvolvimento econômico e social, incentivando as ações entre governo a comunidade e a iniciativa privada.

O estimulo a projetos que viabilizem as utilizações econômicas, culturais e sociais das áreas em recuperação e que aumentem a consciência da população sobre a importância de se preservar o acervo existente tem sido o foco buscado pelo programa, com a atuação em diferentes frentes: Investimentos Integrados em Áreas de Projetos; Fortalecimento Institucional; Promoção de Atividades Econômicas; Capacitação de Artífices e de Agentes Locais de Cultura e Turismo; Programas Educativos sobre o Patrimônio Histórico.

\footnotetext{
66 Informações sobre o Programa Petrobras Cultural (PPC), disponíveis em:

<http://www.hotsitespetrobras.com.br/ppc/apresentacao.asp>. Acesso em: 02 mai. 2011.

67 Informações sobre o BNDES Procult disponíveis em:

$<$ http://www.bndes.gov.br/SiteBNDES/bndes/bndes pt/Areas de Atuacao/Cultura/Procult/apoio patri monio cultural.html>. Acesso em: 02 mai. 2011.
} 
Ao longo dos anos de parceria com o IPHAN, o programa Monumenta sofreu algumas alterações como a ampliação do seu quadro de atuação territorial com acréscimos de novas cidades a exclusão de outras, desenvolvimento de ações de preservação sustentada, bem como a incorporação do IPHAN na coordenação técnica do programa e, em 2006 o coordenador do programa é nomeado Presidente do IPHAN e a estrutura administrativa do programa se incorpora ao Instituto.

Além destas, outras instituições e empresas privadas, aqui não mencionadas, também tem apoiado as atividades na área de preservação do patrimônio. Em função desses apoios e patrocínios cresceram as práticas de conservação e restauração. $O$ crescimento das obras gera também a solicitação por profissionais para a atuação na área.

As exigências por parte dos patrocinadores se restringem aos aspectos de ordem financeira, como o gerenciamento dos recursos financeiros fornecidos ao projeto, de ordem administrativa, relacionada a prazos de execução e outros trâmites burocráticos e de comunicação, com a divulgação das atividades e o marketing.

Aspectos relacionados à área técnica como os critérios, procedimentos adotados e a qualidade da intervenção não são necessariamente considerados como predominantes e, portanto, acabam por permitir que as mais variadas formas de intervenção possam ocorrer na edificação e nos bens integrados, quer sejam eles tombados ou não.

Neste contexto a comunidade, tanto aquela que tem o contato diário e direto como a obra, quanto aquela que faz parte do entorno onde a obra e a edificação se encontram, desempenha um papel fundamental na preservação da arte mural.

Enquanto bem integrado é importante que aqueles que tenham contato direto ou indireto com a obra, principalmente os que estejam próximos dela, sejam capazes de reconhecê-la em seu significado cultural, artístico, histórico, etc.

A comunidade do local onde a obra se encontra, embora não tenha o contato diário e direto com a obra também é um elemento importante. Ela deve fazer parte, assim como os especialistas na área (conservadores-restauradores, historiadores da arte, proprietários, representantes do órgão de preservação, etc) do grupo componente do reconhecimento dos valores culturais atribuídos a obra e ao local onde ela se encontra. 
Ao analisar os valores da conservação do patrimônio TORRE e MASON (2000) consideram que os valores são a razão pelo qual o patrimônio tem sido conservado e ao considerá-los devem ser evidenciados não somente aqueles definidos pelos experts, mas também por aquelas pessoas ou grupos que tenham poder de decisão como é o caso dos valores sociais e econômicos.

Essa situação se traduz, na participação mais democrática nas decisões acerca do bem cultural. A participação é o reflexo das necessidades advindas com a ampliação do conceito de patrimônio e do seu reconhecimento como um patrimônio multivalente e com valores mutáveis. Os valores sociais serão, portanto determinados pelo interesse coletivo sobre o bem.

Os princípios da conservação tradicional estão centralizados nos valores materiais do patrimônio, enquanto no novo conceito de conservação, já expandido para a amplitude das necessidades do patrimônio cultural, destaca que os valores culturais (econômicos, de uso, estéticos e sociais) passam a ter uma importância significativa e as decisões de preservação devem incluí-los. Eles são provenientes não somente do conhecimento dos experts, mas da sociedade interessada como um todo. A inserção de novos métodos de avaliação, oriundos de diferentes áreas como a da economia, a ambiental, etc, refletem a diversidade de profissionais a serem envolvidos e os desafios a serem vencidos.

Cabe aqui mencionar que não é o intuito deste trabalho discutir a forma de definição destes valores o que implicaria na adoção de determinados conceitos e métodos que fogem a proposta da hipótese desta tese, embora eles estejam em geral a ela relacionados. Todavia, salientamos que essa discussão, como coloca TORRE e MASON (2000), é baseada em métodos antropológicos e etnográficos e é realizada dentre tantos pesquisadores que se dedicam ao tema, por Setha M. Low, ${ }^{68}$ citada pelos autores.

\footnotetext{
${ }^{68}$ No relatório de pesquisas do CGI Getty Conservation Institut de 2000 sobre "Values and Heritage Conservation" Marta de La Torre e Randall Mason reunem textos de pesquisadores abordando questões relacionadas à avaliação de valores associados ao patrimônio cultural.
} 


\section{3 - Conservação e Restauração da Arte Mural - Considerações Sobre a Prática:}

\subsubsection{Problemas da atuação prática.}

Através do levantamento realizado das obras foi possível determinar algumas questões relativas à problemas da atuação prática.

Verificou-se que algumas obras murais haviam passado por intervenções anteriores de diferentes naturezas relacionadas à prática da repintura, à remoção ou ao acréscimo de um painel de recobrimento das obras, à remoção da obra de seu local de origem e à soluções de problemas estéticos gerais causados por diversos fatores.

No gráfico a seguir pode-se ter uma noção das intervenções que algumas obras de artistas do grupo em estudo sofreram ao longo destes quarenta anos.

As obras que mais sofreram intervenções foram as do artista Clóvis Graciano independentemente do local onde elas se encontravam, que poderia ser tanto interna quanto externamente a uma edificação, seguidas das obras do artista Fulvio Pennacchi, que também teve várias obras que sofreram intervenções já desde a década de 80.

Em relação aos outros artistas pouca informação se tem sobre as intervenções, pois as obras não existem mais, ou eles apenas participavam na execução das encomendas feitas a seus respectivos colegas. 


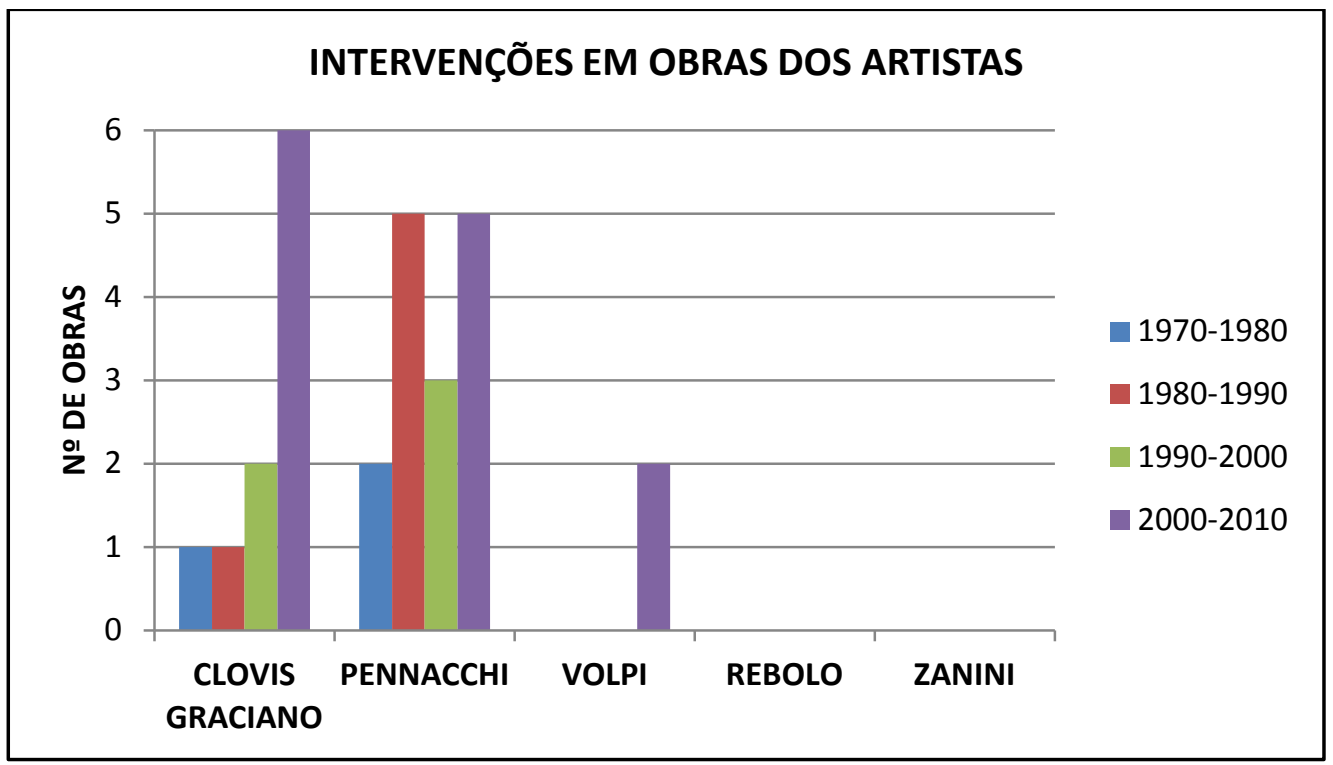

Gráfico 7 - Intervenções em obras dos artistas

Ao constatar essa diversidade de tipos de intervenções procurou-se levantar as causas geradoras dessas situações.

As intervenções foram em sua maioria solicitadas pelos proprietários das edificações, pelos parentes do artista, por instituições públicas responsáveis pela preservação ou pela própria comunidade.

A principais causas para a realização das intervenções foram o estado de conservação ruim em função da falta de manutenção e conservação na edificação (Volpi, Penacchi), o vandalismo (Clovis Graciano), mudança de gosto (Pennacchi), mudança de uso (Pennacchi), incêndio (Pennacchi), demolição da edificação (Pennacchi).

Foram identificadas obras de Pennacchi e de Clovis Graciano que apresentavam problemas estruturais, decorrentes de rachaduras na edificação, mas que ainda não haviam sofrido intervenção de restauração para recuperá-las.

Alguns tipos de intervenções chamaram a atenção, quer pelo número de vezes realizadas quer pela solução adotada.

No primeiro caso constatou-se que várias obras do artista Fulvio Pennacchi foram removidas de seus locais de origem em função da destruição das residências onde elas se encontravam ou da mudança dos proprietários dos locais e/ou a venda dos imóveis onde elas foram executadas. 
A maior parte delas foi realizada com o conhecimento da família do artista e, muitas vezes, por intermédio da própria famíla, que indicava um engenheiro para execução do serviço, sendo este, o responsável por varias remoções das obras deste artista ${ }^{69}$.

As remoções geralmente exigiram um planejamento minucioso de execução de obra de engenharia, com cálculos e um toda uma logística de deslocamento e transporte da obra para o novo local, pois elas eram retiradas junto com toda a parede, no método do stacco a massello, ${ }^{70}$ o termo técnico usado na área de conservação e restauração para esse procedimento.

A maioria das remoções foram executadas em décadas anteriores, $1970 \mathrm{e}$ 1980, quando a expansão urbana gerou a demolição de várias áreas e residências para implantação de edifícios ou outras construções.

Algumas foram transportadas para outros locais, novas residências dos antigos proprietários do imóvel demolido ou recolocadas em locais comerciais que, posteriormente, também passaram a ter novos usos.

Embora as razões pelos quais as obras foram removidas de seus respectivos locais de origem tenham sido diferentes, esse tipo de ação revela a atenção com a preservação da obra do artista evitando que ela fosse destruída com a perda do imóvel.

Nos casos citados, a intervenção de remoção foi executada por um profissional que não foi o mesmo que executou a restauração das obras. Tendo em vista a complexidade do processo de remoção de toda a parede é necessário um trabalho conjunto com outro profissional da área de engenharia para que cálculos sejam realizados e não se corram tantos riscos na sua execução, nem da remoção e nem da recolocação em outro local.

${ }^{69}$ Em depoimento à autora, em 2005, o engenheiro Paulo Sproviero, relatou que realizou várias remoções de obras, ainda com o artista vivo. Ele também relatou que muitas das obras após serem reinstaladas em outros locais eram retocadas pelo próprio artista.

${ }^{70}$ Stacco a massello é o termo em italiano usado para designar a remoção de uma pintura mural de seu local de origem e execução, juntamente com toda a parede onde ela se encontra e que lhe serve de suporte. 


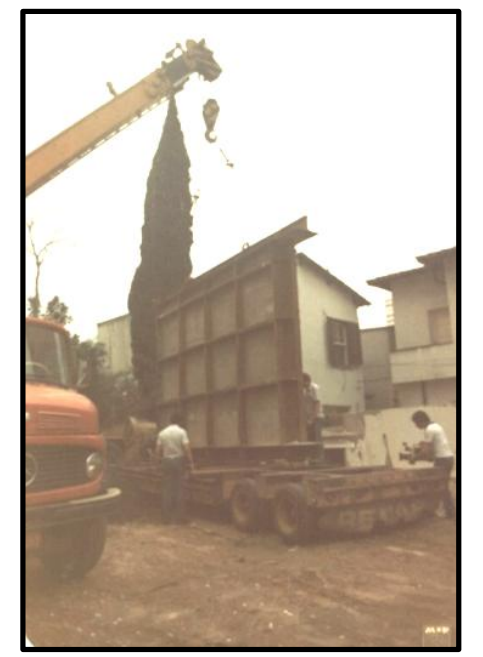

Figura 6 Remoção da obra de Pennacchi Foto: Eng‥ Paulo Sproviero, 1982.

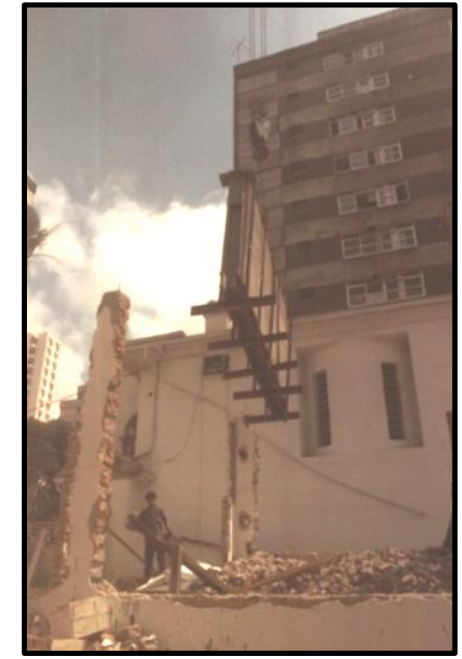

Figura 7 Remoção da obra de Pennacchi Foto: $\quad$ Eng ${ }^{\circ}$. Paulo Sproviero, 1982.

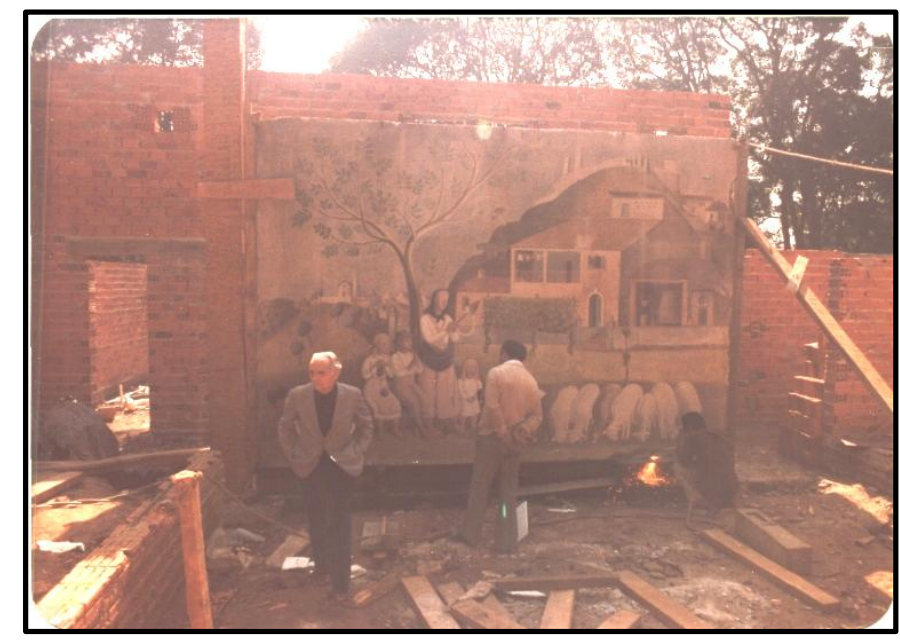

Figura 8 Artista com sua obra reinstalada em novo local. Foto: Eng‥ Paulo Sproviero, 1984.

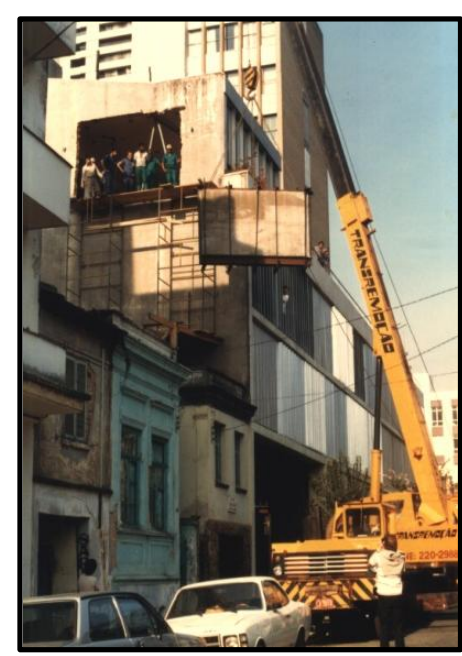

Figura 9 Colocação de obra em novo local Foto: $\quad \mathrm{Eng}^{\circ}$. Paulo Sproviero 1986

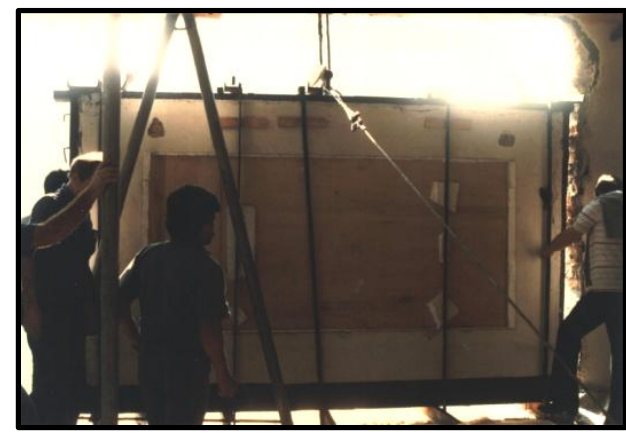

Figura 10 Colocação de obra em novo local Foto: $\quad$ Eng ${ }^{\circ}$. Paulo Sproviero 1986 
No ano de 2009, uma outra obra do mesmo artista foi removida do local onde se encontrava em função da destruição do imóvel causada por um incêndio. O imóvel era a antiga sede do Banco Auxliar de São Paulo, no centro da cidade, que funcionava como uma loja de peças automotivas. A obra que fora executada na parede de fundo do imóvel, foi removida e transportada para uma cidade no interior de São Paulo e os trabalhos de restauração serão iniciados ainda este ano de $2011 .^{71}$

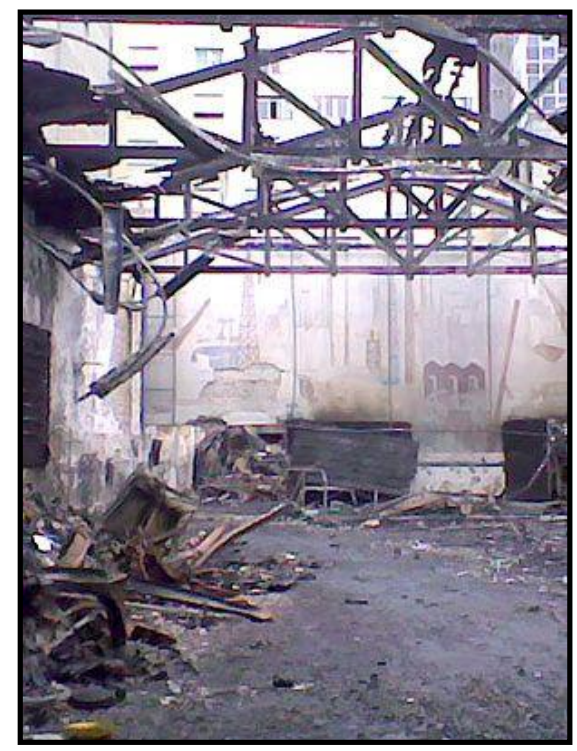

Figura 11 Mural exposto na parede dos fundos da loja Lopan, na av. Duque de Caxias, 136, São Paulo.

Foto: Walter Tabax/vc repórter $^{72}$

Observa-se que vem crescendo um movimento de remoção das obras murais, em geral de artistas famosos, de seus respectivos locais de origem. Os motivos refletem as necessidades impostas para a sua preservação e também uma nova visão e postura que considera este tipo de obra como investimento por galeristas ou marchands.

A mudança de uso das edificações também se impõe como uma questão bastante delicada no caso da preservação da arte mural, fundamentalmente porque muitas vezes implica na sua destruição ou em uma remoção do local onde originalmente ela foi executada.

\footnotetext{
${ }^{71}$ Informação fornecida à autora em conversa telefônica em janeiro de 2011 com o representante da empresa que irá fazer a restauração a partir de março de 2011.

${ }_{72}$ Disponível em <http://noticias.terra.com.br/brasil/interna/0,,Ol3746483-El8139,00.html >. Acesso em: 09 fev. 2011.
} 
Esta questão pode estar mais relacionada ao gosto do que propriamente ao novo uso do espaço. Todavia, é uma questão a ser considerada, pois diferentes medidas podem ser adotadas para que a obra não seja destruída, garantindo a sua preservação, caso posteriormente um novo proprietário ou usuário do imóvel tenha interesse em mostrá-la e evidenciá-la ao público, mesmo que situada em espaços fechados e restritos.

Considerando essa situação, destaca-se um outro tipo de intervenção realizada nas obras ao longo dos anos, neste caso principalmente em espaços internos das edificações, que foi a utilização de painéis de madeira ou gesso acartonado para recobrimento dos murais. Essas estruturas de recobrimento eram geralmente realizadas pelos locatários ou proprietários de imóveis onde se localizavam esses murais e os motivos eram os mais variados, mas principalmente relacionados à questão do gosto estético, ou da compatiblidade com o novo uso da edificação.

Alguns murais tiveram essas estruturas de recobrimento retiradas nestes últimos anos e foram novamente expostos como é o caso da obra de Fulvio Pennacchi executada em uma antiga residência no bairro dos Jardins projetada pelo arquiteto Miguel Forte e que, posteriormente, funcionou como estabelecimento comercial, período no qual, o mural lá existente permaneceu recoberto.

Somente ao ser adquirida por uma imobiliária, em 2006 e estabelecendo-se como local de serviços é que o mural teve o painel que o recobria removido, permitindo que a obra fosse novamente apreciada pelos usuários da edificação e pelos frequentadores do local.

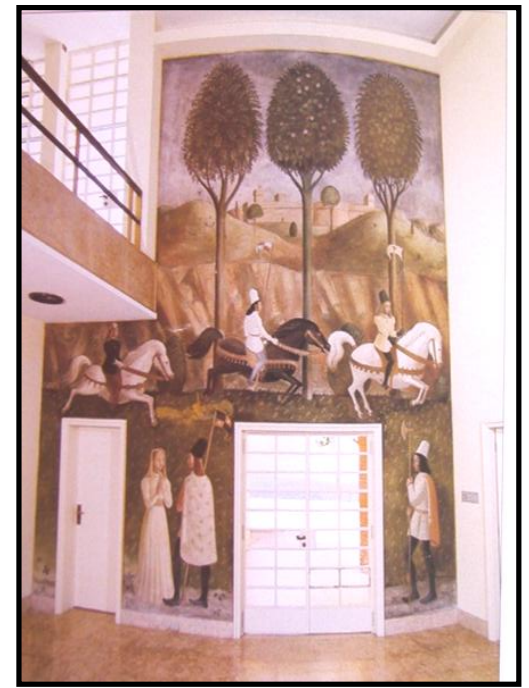

Figura 12 Mural Cavalgada Medieval Fonte: PENNACHI, 2002

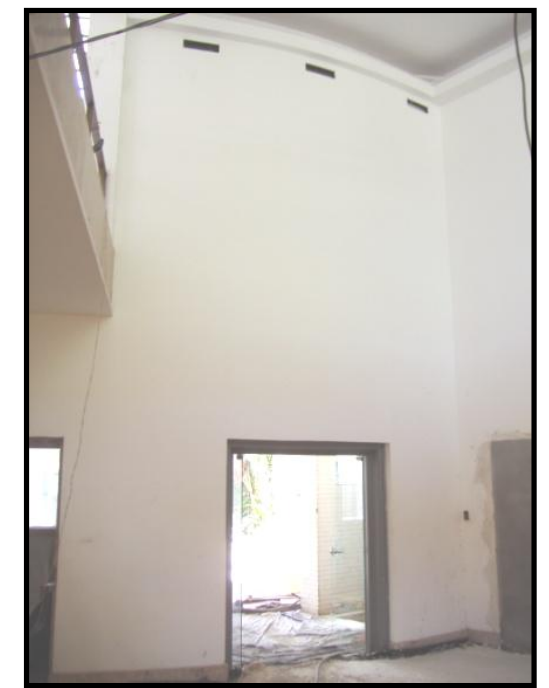

Figura 13 Painel de gesso recobrindo o mural Foto: Vera Wilhelm, 2006 


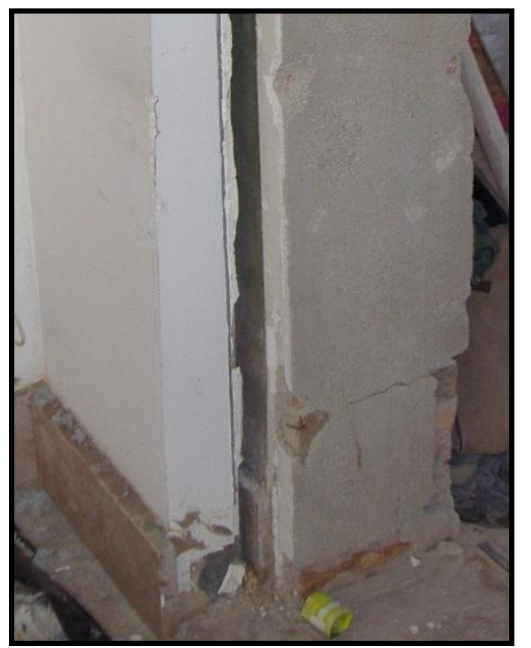

Figura 14 Painel de gesso recobrindo o mural Foto: Vera Wilhelm, 2006

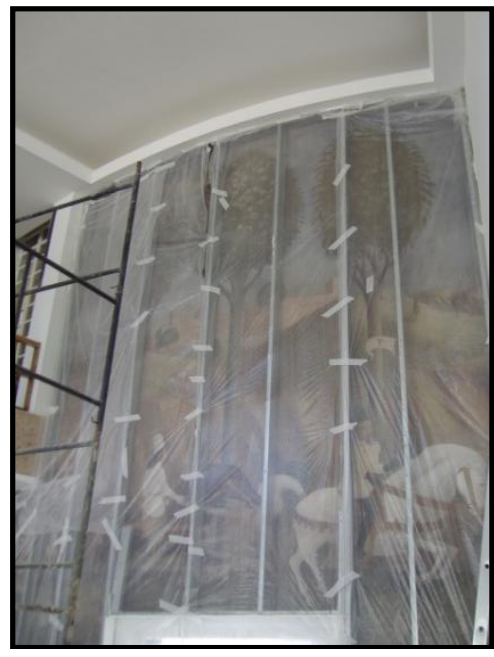

Figura 16 Painel de gesso removido Foto: Vera Wilhelm, 2006

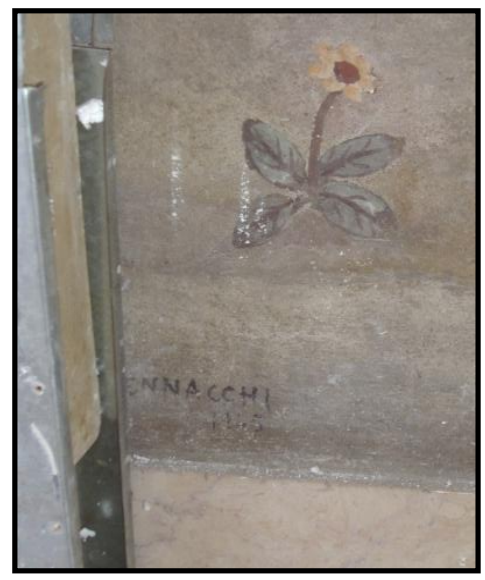

Figura 18 Detalhe da assinatura Foto: Vera Wilhelm, 2006

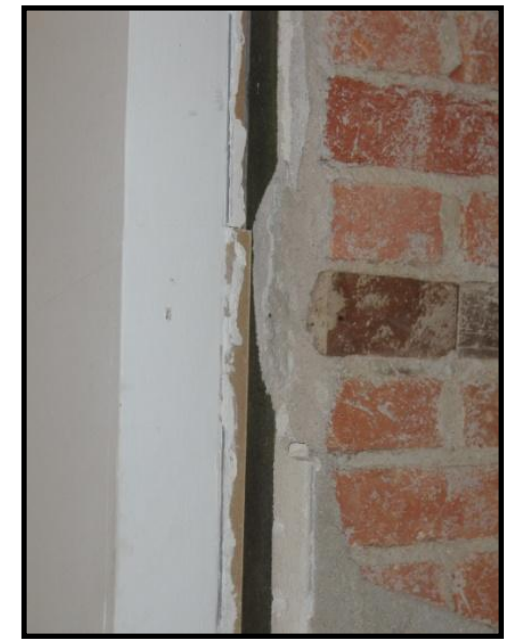

Figura 15 Detalhe do painel de gesso Foto: Vera Wilhelm, 2006

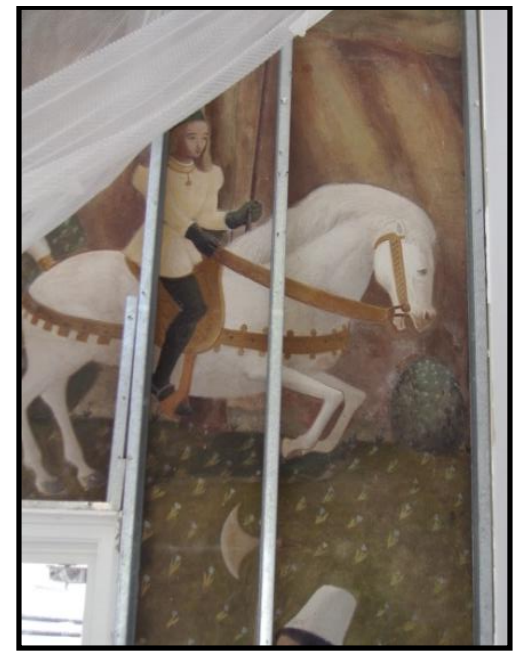

Figura 17 Detalhe do mural

Foto: Vera Wilhelm, 2006

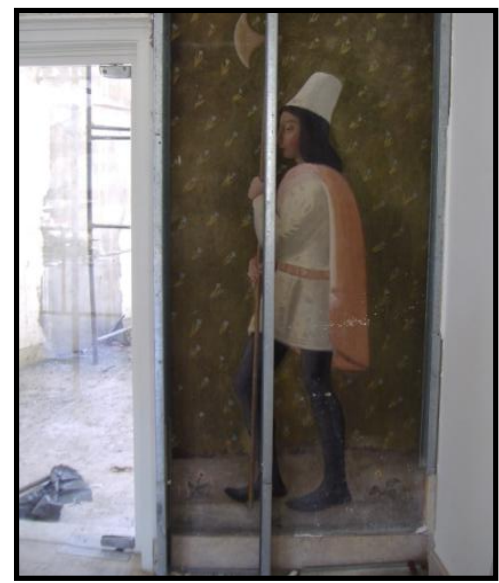

Figura 19 Detalhe do Mural

Foto: Vera Wilhelm, 2006 
Após a remoção da estrutura de recobrimento do mural foi realizada a intervenção de restauração por uma empresa contratada.

Um outro exemplo semelhante foi a obra intitulada "Ceia de Emaús" do mesmo artista executada no antigo Edifício da Liga das Senhoras Católicas no centro da cidade. A edificação foi posteriormente adquirida pelo Grupo Silvio Santos e hoje funciona como sede de uma de suas empresas. O mural foi executado em um dos andares do prédio, local onde a empresa instalou a sala da diretoria.

Ele permaneceu, durante um período de tempo, recoberto por uma estrutura que foi posteriormente, em 1994, removida para que fosse executada a intervenção de restauração no mural. Na ultima década ${ }^{73}$ o mural foi novamente recoberto com uma estrutura para atender a solicitação do novo diretor que não queria que a obra ficasse exposta.

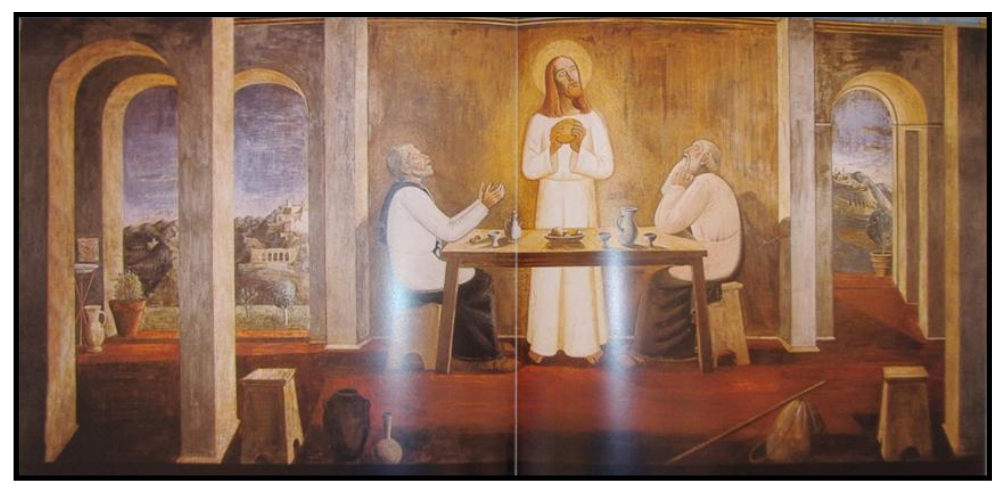

Figura 20 Mural "Ceia dos Emaús" 1956

Fonte: PENNACCHI, 2002, p. 86-87

As intervenções acima citadas representam dois casos onde a construção de uma estrutura de recobrimento sobre a obra teve o objetivo de resolver uma questão bastante comum da preservação deste tipo de arte que é a do gosto estético aliado também, a mudança de uso do local.

As medidas adotadas representam soluções mais condizentes com os princípios de preservação 'in loco' mencionados já em vários documentos e reiterados pelos princípios do $\operatorname{ICOMOS}^{74}$. Deve-se destacar, também, que as medidas adotadas permitem uma reversibilidade de solução, mais do que

\footnotetext{
${ }^{73}$ Segundo depoimento do responsável pelo setor de manutenção da empresa fornecido a autora em entrevista realizada em 2006, o mural foi novamente recoberto, mas a visita ao local não foi permitida. ${ }^{74}$ Princípios do ICOMOS para a Preservação e Conservação - Restauração das Pinturas Murais (2003) disponível em:< http://www.international.icomos.org/charters/wallpaintings e.htm $>$. Acesso em 25 mar. 2005. Ver anexo II.
} 
propriamente uma reversibilidade de intervenção, principalmente por não terem sido executadas diretamente sobre a própria obra o que possibilitou a preservação da integridade e da unidade da obra. Embora, se saiba que em alguns casos esse tipo de solução adotada proporciona a criação de um micro clima que possivelmente pode gerar alguns problemas posteriores.

Estas foram soluções adotadas em função das exigências das respectivas obras, mas podem vir a constituir medidas a serem pensadas e consideradas para outros casos, onde também, se deseja preservar o mural sem, contudo, mantê-lo visível.

Cabe enfatizar que nem todas as obras murais são tombadas ou se encontram em edificações tombadas, pois não existe legislação de tombamento específica para um mural.

Em 2004, no entanto, destaca-se um caso particular de tombamento de fachada ${ }^{75}$ com mural executado em grandes dimensões e sendo este o elemento predominante na fachada e que resistiu a destruição causada pelo fogo na edificação.

O tombamento ocorreu em nivel estadual pelo CONDEPHAAT quatro anos mais tarde com a resolução SC-51, de 05-08-2009, processo ํㅜ 33.188/95 em que se deliberou a aprovação do tombamento do remanescente da fachada original do Teatro Cultura Artística, o acesso do foyer e o painel de autoria de Di Cavalcanti, do Teatro situado na Rua Nestor Pestana no 196, nesta Capital. No tombamento estadual fica, portanto, evidente o destaque do mural como elemento a ser tombado.

Apesar da obra mural presente nesta fachada não fazer parte do recorte estabelecido para o estudo deste trabalho, ele é aqui mencionado pois eventualmente pode representar um precedente em tombamentos futuros sobre murais. Porém, espera-se que não na mesma situação em que ocorreu com o exemplo citado, após a destruição quase que total do imóvel.

\footnotetext{
${ }^{75}$ Para consulta à resolução de tombamento deste caso particular da obra do artista Di Cavalcanti no Teatro Cultura Artística ver site do CONDEPHAAT. Disponível em: $<$ http://www.cultura.sp.gov.br/portal/site/SEC/menuitem.bb3205c597b9e36c3664eb10e2308ca0/?vgn extoid=91b6ffbae7ac1210VgnVCM1000002e03c80aRCRD\&ld=82dd16774312b210VgnVCM1000004 c03c80a >. Acesso em: 27 abr.2011.
} 


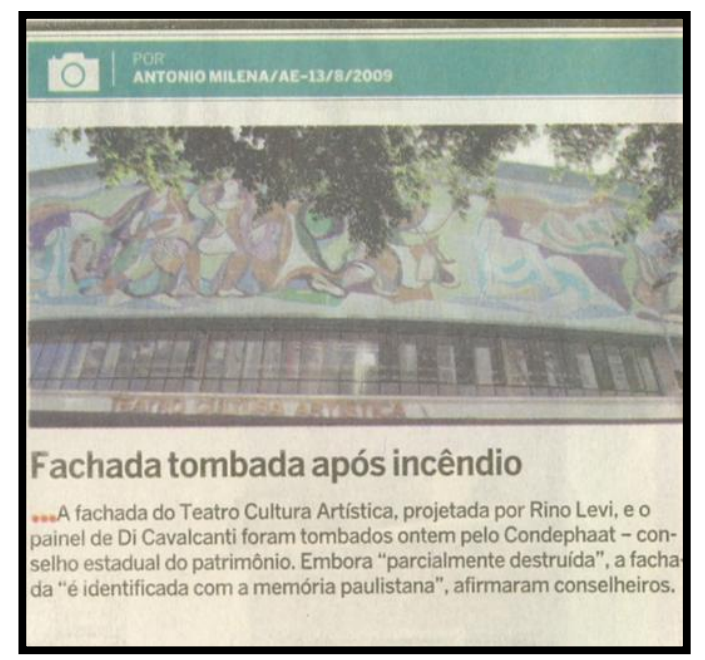

Figura 21 Tombamento de fachada.

Fonte: Jornal O Estado de São Paulo 04 set. 2009. ${ }^{76}$

Um outro tipo de intervenção foi realizada nas obras de dois artistas diferentes Fulvio Pennacchi e Clovis Graciano com a finalidade de proteção das obras contra ações de vandalismo, tanto internamente quanto externamente nas edificações.

O tipo de solução adotada foi basicamente o mesmo para os dois casos, embora eles tivessem sido executados em locais diferentes. A proteção da obra mural foi realizada com uma parede de vidro distante de 10 a $20 \mathrm{~cm}$ do mural composta por placas de vidro sustentadas ou não, por uma estrutura metálica.

A solução tem atendido as exigências de proteção até o presente momento, ainda que apresente a desvantagem de gerar reflexos na visibilidade da obra. No caso da proteção executada no mural externo os reflexos são ainda mais intensos, dificultando a visualização do mural.

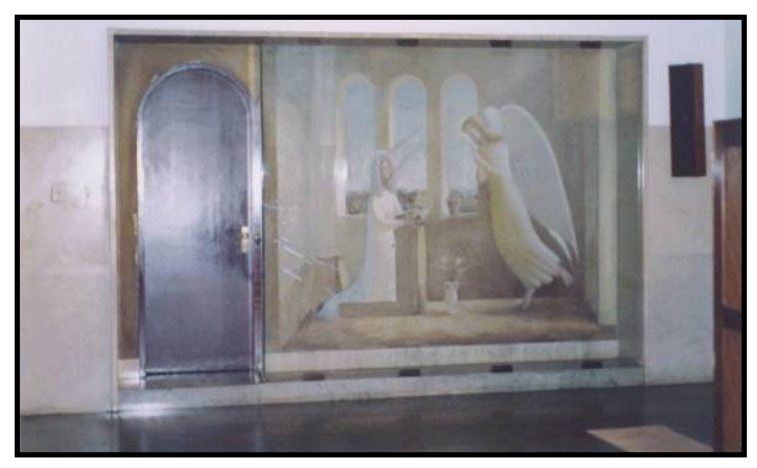

Figura 22 - Proteção de vidro no mural interno Foto: $\quad$ Vera Wilhelm, 2006

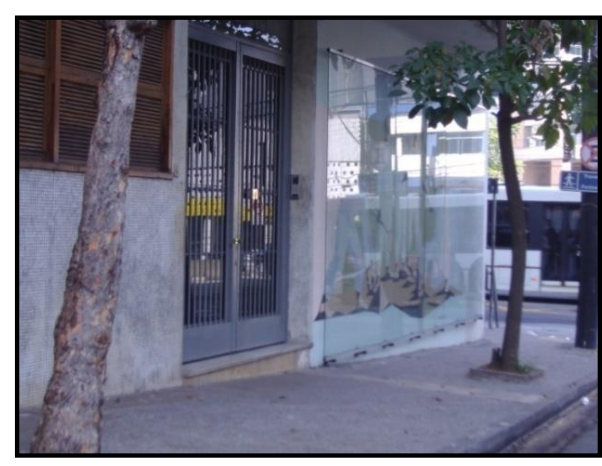

Figura 23 - Proteção de vidro no mural externo Foto: Vera Wilhelm, 2008

${ }^{76}$ Disponível também em:

<http://www.estadao.com.br/estadaodehoje/20090904/not_imp429415,0.php>. Acesso em: 25 mar. 2011. 
A pesquisa de campo realizada no local onde se encontram as obras, juntamente com a consulta realizada à profissionais da área, permitiu identificar que os problemas mais frequentes encontrados nas obras estão relacionados à camada pictórica e ao desprendimento da argamassa, mais do que às questões de ordem estrutural.

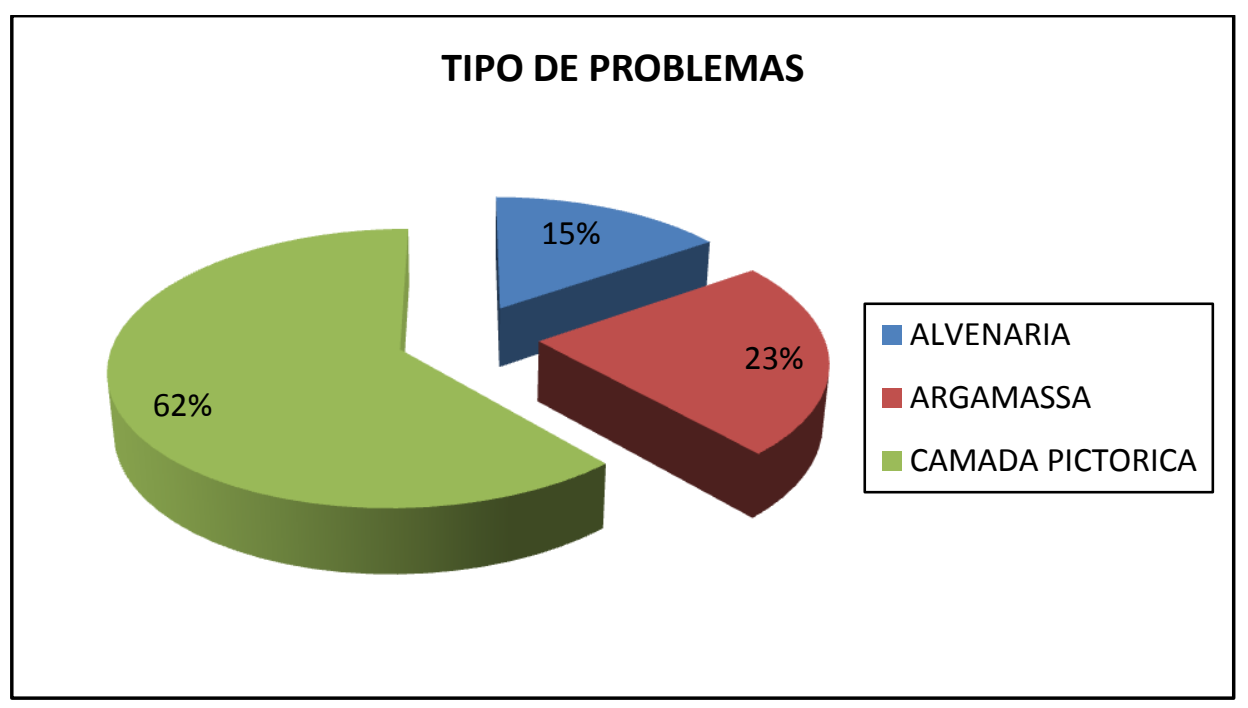

Gráfico 8 - Tipos de problemas freqüentes encontrados nas obras

Entre os fatores que afetaram a camada pictórica estão os processos de deterioração causados por escorrimento de água, cujas fontes foram infiltração de umidade através do telhado ou laje, manchas causadas devido à ascensão de umidade por capilaridade, drenagem inadequada, presença de sais, além de problemas relacionados à perda da camada pictórica, ou de tesselas de mosaicos de pastilhas, de quebra de material cerâmico, etc.

Outro aspecto considerado na consulta feita aos profissionais da área foi a facilidade e o acesso a realização de exames analíticos que pudessem confirmar hipóteses sobre a composição material das obras e sobre os processos de degradação.

Embora as respostas fornecidas por algumas empresas tenham sido de que elas tinham acesso a esse tipo de serviço, não pudemos confirmar, em relatórios, a presença de registros de análises realizadas. Talvez pelo fato de que as intervenções que eventualmente se utilizaram destes recursos tivessem sido feitas 
em obras sem nenhuma proteção legal e, portanto, não documentadas nas instituições.

Houve também o reconhecimento, por parte de outras empresas, de que havia uma dificuldade de acesso para a realização destes exames e também de que novas exigências na execução de trabalhos na área têm sido introduzidas, principalmente da última década para cá sem, contudo, mencionar quais foram.

\subsubsection{Critérios de Avaliação das obras de Restauração.}

A avaliação dos trabalhos de conservação e restauração de obras de arte e/ou bens integrados, dentre eles os murais, é um campo ainda a ser desenvolvido no nosso país.

Uma tarefa difícil de realizar se não existe uma compreensão geral sobre os conceitos, princípios e procedimentos de intervenção. Motivo pelo qual, determinadas colocações aqui anteriormente feitas, em relação a uma padronização documental e de determinação de conceitos, podem colaborar na uniformização da linguagem e na estruturação de uma base de avaliação.

Apesar de cada obra ter suas características e exigências peculiares, questões conceituais e de normalização podem e devem ser trabalhadas com 0 intuito de melhor estruturar o setor e facilitar a avaliação dos técnicos do corpo institucional.

Os parâmetros "legais" até agora considerados para a capacitação de coordenação e execução de trabalhos de conservação e restauração estão restritos à carreira do arquiteto e foram estabelecidos pela legislação, Decisão Normativa CONFEA № 83, de 26 de Setembro de 2008, apenas em anos recentes, organizando, assim, a atuação do profissional do setor de construção civil neste ramo de atividade de conservação e restauração que se encontra em expansão no nosso país.

A Decisão Normativa CONFEA № 83, de 26 de Setembro de 2008, estabelecida pelo órgão regulador da atuação profissional em nível federal, considera que, para o exercício da atividade de conservação, reabilitação, reconstrução e restauração em monumentos e sítios de valor cultural é exigido do profissional, conhecimentos em diversos campos, a saber: História da Arte e da 
Arquitetura, Teoria da Arquitetura, Técnicas e Materiais Tradicionais, Estética, Planejamento Urbano e Regional, Ciências Sociais e Técnicas Retrospectivas que somente o profissional formado em Arquitetura e Urbanismo recebe em seu currículo escolar, aprovado pela Portaria MEC № 1.770, de 21 de dezembro de 1994 e constante das diretrizes curriculares de Arquitetura e Urbanismo, fixadas por meio da Resolução CNE/CES no 06, de 2 de fevereiro de 2006, além de outros conhecimentos da área de engenharia.

Portanto, o campo regulador se encontra restrito às intervenções em edificações, bens culturais imóveis e não é aplicado aos bens culturais integrados e móveis. Isto cria, muitas vezes, situações delicadas entre profissionais que deveriam trabalhar em conjunto como o restaurador e o arquiteto, em função de conflitos surgidos pela falta de clareza nas funções de execução de atividades relacionadas à alguns procedimentos técnicos.

As causas desta inexistência de normas específicas para avaliação de trabalhos de conservação e restauração estão relacionadas a princípio ao não reconhecimento da profissão de conservador-restaurador. Apesar da profissão não ser reconhecida também em vários países europeus, nestes países existem códigos de ética que estabelecem diretrizes para o exercício da profissão, enquanto no contexto brasileiro a criação de um código de ética para o exercício da profissão só ocorreu em 2005.

$\mathrm{Na}$ busca de informações sobre a fundamentação teórica para a realização e avaliação de trabalhos de conservação e restauração foi possível encontrar em sites de instituições internacionais reguladoras do exercício da profissão de conservador restaurador como AIC a IIC sistemas de acreditação, ou seja, do estabelecimento de hierarquias segundo a formação e experiência dos profissionais.

A realidade da profissão no Brasil está em processo de mudanças graças aos esforços de profissionais da área para a regulamentação da profissão.

Apesar da inexistência de um programa de avaliação e de gestão de qualidade aplicado a área de bens culturais integrados, a necessidade do processo se torna cada vez mais veemente em função da expansão da demanda de trabalhos na área e, também, de algumas experiências não bem sucedidas.

A avaliação e o controle de qualidade nos trabalhos de conservação e restauração podem e devem seguir um processo semelhante ao padrão de controle 
de qualidade, estabelecidos para as distintas áreas onde o conceito já é aplicado. Situação semelhante tem ocorrido com o a transferência dos programas de gerenciamento de riscos, aplicados em outros segmentos de atividades e serviços, para o setor de patrimônio cultural.

A avaliação e controle não devem ser realizados após a execução dos trabalhos, mas introduzidos e considerados já na fase inicial da estruturação do projeto de conservação e restauração, de forma a permitir que se faça um acompanhamento minucioso das etapas evolutivas e não uma inspeção e/ou checagem no período final.

Essa etapa inicial de planejamento, possivelmente exigirá mais tempo em preparativos por parte do profissional que irá executar a obra, mas também garantirá significativos ganhos de tempo e custos para a preservação do patrimônio, o planejamento e a gestão da obra a médio e longo prazo.

Portanto, a criação de um modelo básico padronizado com uma estruturação de dados para registro e acompanhamento é extremamente necessário, por parte das instituições, pois as obras são geralmente executadas e não recebem um acompanhamento posterior de conservação, manutenção ou monitoramento.

A existência de um documento internacional específico da área de conservação de murais pode contribuir e orientar na estruturação de uma metodologia de trabalho que venha a complementar aquela já desenvolvida na conservação da arquitetura e que possa se integrar a um programa de conservação preventiva por parte das instituições responsáveis pelo controle e fiscalização das obras de conservação e restauração.

No continente europeu as questões relacionadas à formação, ética, atuação profissional, padronização e avaliação das práticas, já vêm sendo trabalhadas há anos. Isso reflete as necessidades surgidas em função de experiências de intervenções na área, muitas vezes não bem sucedidas, além do fato de ter ocorrido um aprimoramento das pesquisas com os materiais utilizados nesses serviços e do atendimento às normas estabelecidas pela Comunidade Européia com relação ao sistema de ensino.

Esforços têm sido realizados no intuito de se conseguir uma garantia da qualidade do ensino, das práticas e também do reconhecimento profissional. Essas 
três frentes, dentre outras, têm sido trabalhadas e nos parecem necessárias para a implementação de um sistema que permita manter a qualidade dos trabalhos.

$\mathrm{Na}$ falta de quaisquer recomendações e documentos relacionados à preservação da arte mural em nossa realidade brasileira torna-se aconselhável a utilização dos Princípios do ICOMOS para a Preservação e ConservaçãoRestauração das Pinturas Murais (2003), como auxiliares e norteadores das medidas de preservação das obras de conservação e restauração a serem adotadas pelos profissionais da área. Transpondo esses princípios para a nossa realidade nacional e regional, mais especificamente para nível local da cidade de São Paulo, cujas particularidades da arte mural diferem de outras regiões, pode-se dizer que uma análise da atuação da preservação da nossa arte mural pode ser pautada e realizada considerando os fundamentos da Teoria da Restauração de Cesare Brandi acrescida pelos princípios enunciados pelo ICOMOS em 2003.

Os aspectos abordados no documento são bastante amplos e englobam a política de proteção, a investigação, a documentação, a conservação preventiva, a manutenção e gerenciamento, os tratamentos de conservação-restauração, as medidas de emergência, a investigação e a informação pública, a qualificação e formação profissional, a tradição de renovação, a cooperação internacional.

A realização de uma carta complementar nacional (com eventuais abordagens regionais) englobando aspectos mais específicos das nossas necessidades e do tipo de bens que possuímos pode representar um passo adiante e avanço na estruturação de diretrizes, caso ela seja implantada.

Neste sentido, acredita-se que São Paulo possa dar uma significativa contribuição a essa realidade por apresentar uma grande concentração de obras de períodos diversos que se estendem de 1930 até a década de 60, produtos da grande expansão da metrópole, do desenvolvimento da arquitetura moderna, bem como da concentração de artistas e empresas que a essa arte se dedicaram, ou mesmo pelas novas tendências desenvolvidas dos anos 1970, até o presente, já dentro de outro contexto.

Essas obras se encontram atualmente ainda ameaçadas, pela expansão imobiliária, por pressões econômicas, pelo abandono, pela inexistência de um trabalho de inventarização geral e de uma política de conservação preventiva. 


\subsubsection{Estudos de casos}

Nos capítulos anteriores foi mencionado que algumas obras murais sofreram diferentes tipos de intervenções. Para estes estudos de casos foram selecionadas duas obras que exemplificam casos ocorridos em períodos diferentes da história e que, todavia, ainda demonstram como a incompreensão dos critérios e princípios da conservação e restauração implicam diretamente na prática da intervenção sobre o bem.

Uma das obras murais se encontra em uma edificação que atualmente está sobre proteção do órgão de preservação municipal e a outra em uma edificação que não recebe proteção legal.

Os dois casos selecionados são de intervenções de repinturas em obras do artista Clóvis Graciano que foram executadas, internamente no Teatro João Caetano e, externamente no Edifício Bienal. A obra do Teatro João Caetano foi destacada na dissertação de mestrado, ${ }^{77}$ porém com um enfoque relacionado à metodologia de intervenção e não em relação a uma abordagem analítica da intervenção realizada.

Estudo de caso ํo 1: Teatro João Caetano.

Este estudo de caso refere-se à obra de Clovis Graciano realizada no Teatro João Caetano, inaugurado em 25 de dezembro de 1952, na Rua Borges Lagoa 650, no bairro de Vila Clementino na cidade de São Paulo.

A edificação foi projetada pelo arquiteto Roberto José Goulart Tibau, importante arquiteto carioca que atuou na década de 40 e 50 e desenvolveu junto a Comissão do Convênio Escolar ${ }^{78}$ inúmeros trabalhos de edificações voltadas para a educação como os parques infantis, as bibliotecas, teatros populares ou teatros de

\footnotetext{
${ }^{77}$ A dissertação de mestrado defendida em 2006 na FAU/USP intitulada A Arte Mural do Grupo Santa Helena: um Estudo para Preservação.

${ }^{78}$ Comissão de Convênio Escolar surgiu de um convênio estabelecido entre a Prefeitura e o Estado no período de 1948 a 1955 coordenada por Hélio Duarte, com finalidade de dotar a cidade de São Paulo de unidades escolares suficientes. Nesta parceria a Prefeitura se encarregava de doar o terreno e o dinheiro para construção dos edifícios e o Estado fornecia os profissionais.
} 
bairros. ${ }^{79}$ As edificações refletiam novos conceitos e relações entre escola e comunidade, portanto as alterações de linhas e formas introduzidas por essa nova arquitetura moderna eram o reflexo das alterações em programas e métodos pedagógicos.

Elementos arquitetônicos característicos da arquitetura moderna como pórtico de composição da fachada criando passagem entre externo e interno, uso de tijolos de vidro em fechamento de parede, visibilidade da área interna pela fachada e execução de obra artística em área da edificação, marcaram não só a execução deste Teatro como a dos outros dois Teatros: o Teatro Arthur de Azevedo (Mooca) realizado no mesmo período e, Teatro Paulo Eiró (Santo Amaro) realizado em 1957.
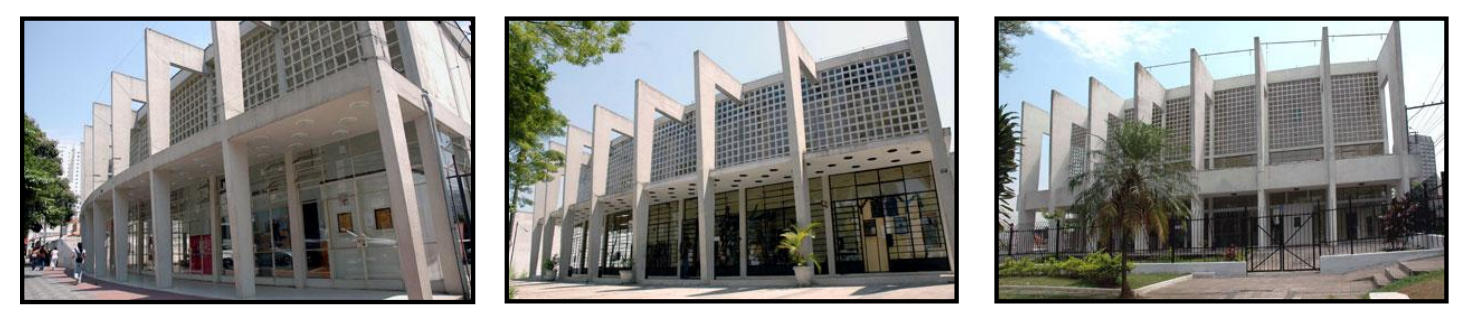

Figura 24 - Teatro João Caetano Figura 25 - Teatro Arthur de Azevedo Figura 26 - Teatro Paulo Eiró Fonte: http://www.prefeitura.sp.gov.br/cidade/secretarias/cultura/dec/teatros

A arquitetura da edificação tombada pelo Conselho Municipal de Preservação do Patrimônio Histórico - CONPRESP pela resolução 29 /Conpresp/92 processo 16003.576-89*78, revela influência de Le Corbusier e se inspira no projeto do Centro Soyus em Moscou na URSS ${ }^{80}$, como menciona o arquiteto Tibau em depoimento, ${ }^{81}$ e segue um projeto padrão criado para a realização dos teatros populares de bairro.

\footnotetext{
${ }^{79}$ Os Teatros Populares ou Teatros de Bairros foram construídos para proporcionar à população áreas de lazer descentralizadas dentro de um programa de planejamento urbano que visava dotar a cidade em crescimento de uma melhor infra-estrutura nos bairros.

${ }^{80}$ O projeto de Le Corbusier, em 1928, para ao Centro Soyuz em Moscou foi o vencedor do concurso e a construção se estendeu até 1935.

${ }^{81}$ Depoimento de José Roberto Tibau à Euler Sandeville Jr., 1985 p.105. O arquiteto Euler menciona também que pode ter havido um possível equívoco do depoimento, pois a semelhança do teatro é com o Palácio dos Soviets e não com o Centro Soyus, ambos em Moscou.
} 


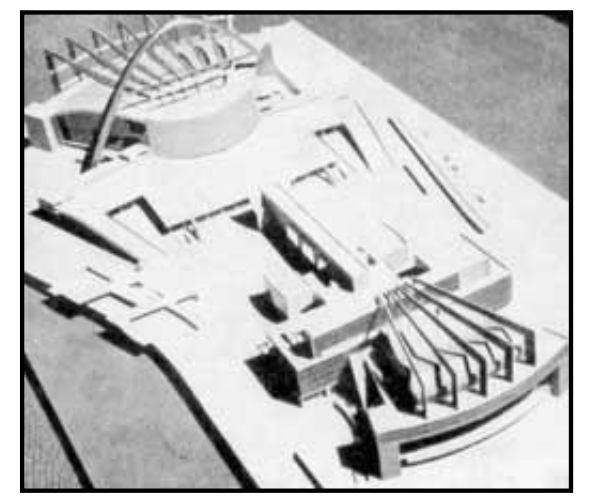

Figura 27 Le Corbusier, Projeto para o Palácio dos Soviets. ${ }^{82}$ Maquete, vista do conjunto. Moscou. 1931

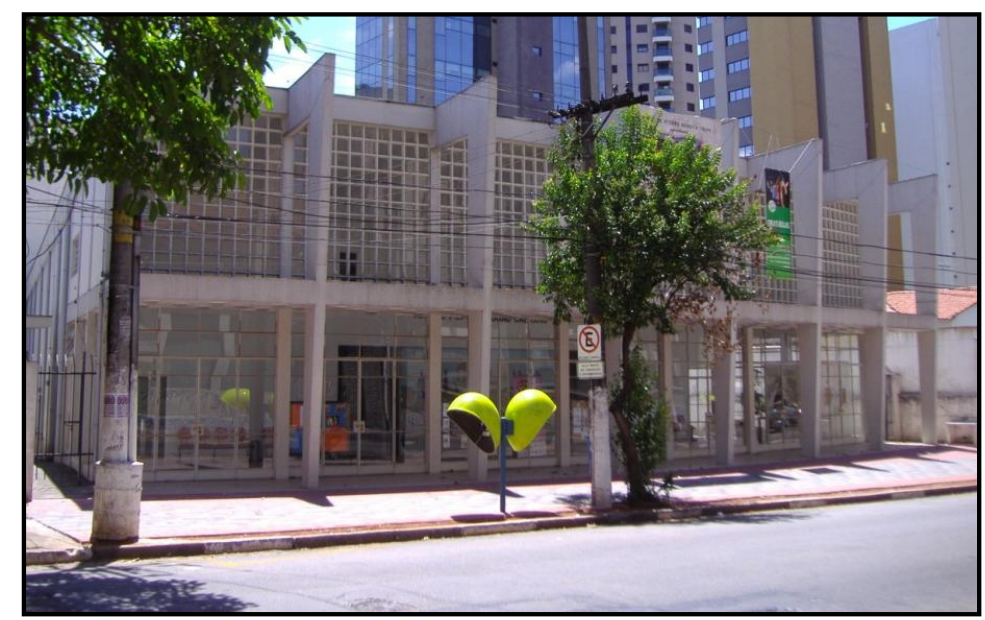

Figura 28 Teatro João Caetano

Foto: Vera Wilhelm, 2006

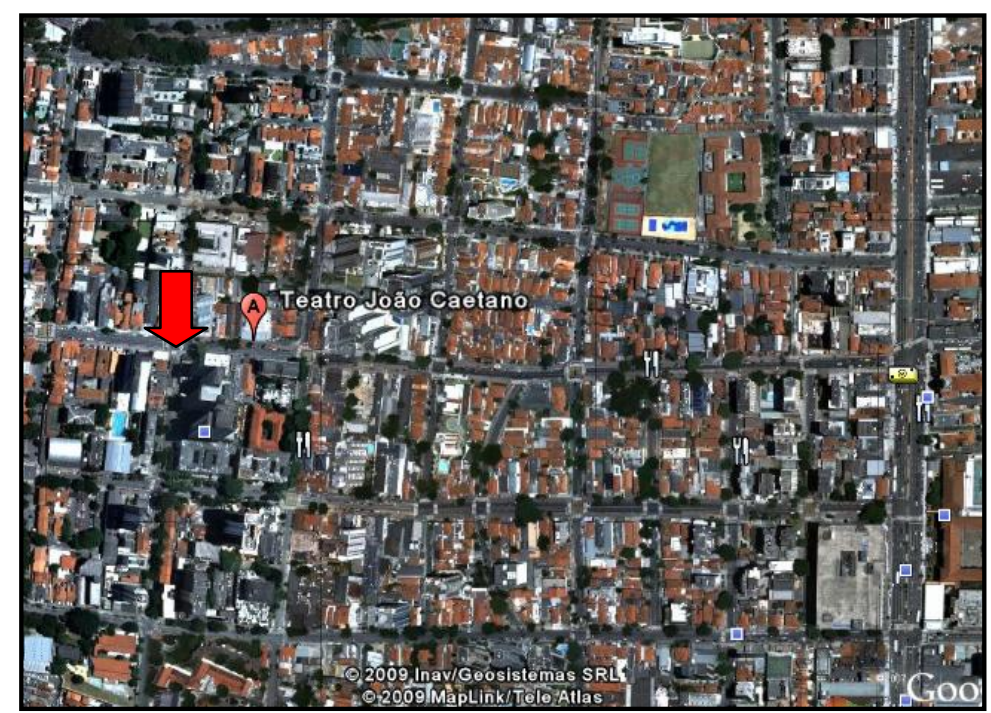

Figura 29 Localização do Teatro João Caetano vista aérea Fonte: Google Earth Plus, 2009

${ }^{82}$ Fonte:<http://www.ufrgs.br/propar/domino/2005 01/txt05 2005 01.htm>. Acesso em 18 dez. 2009. 


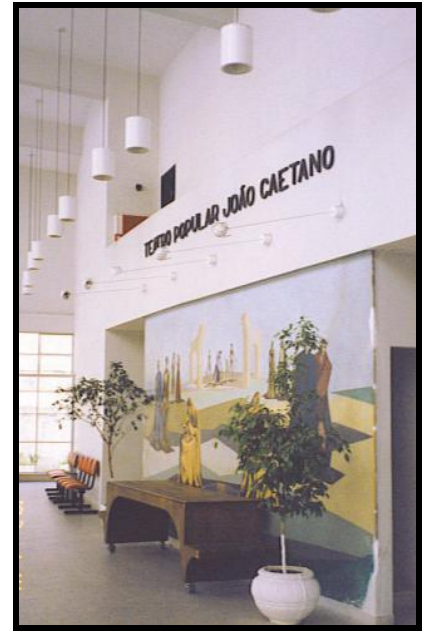

Figura 30 Saguão de entrada Foto: $\quad$ Vera Wilhelm, 2005

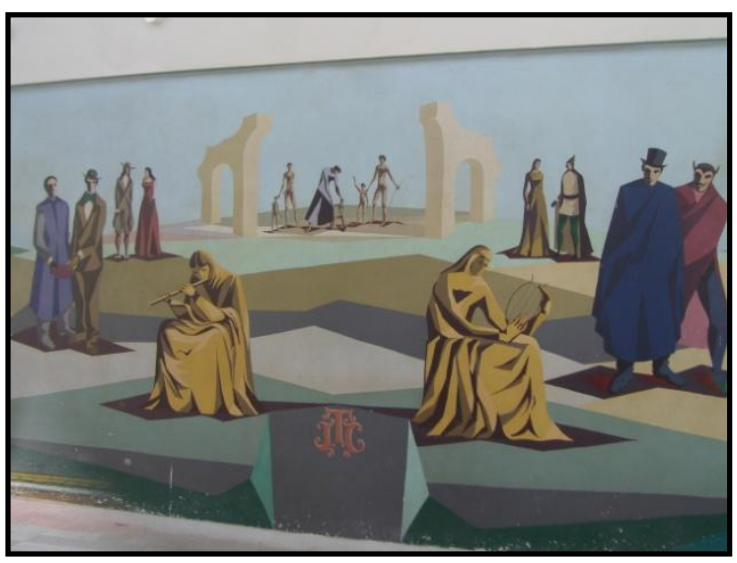

Figura 31 Mural "Alegoria às Artes" Foto: $\quad$ Vera Wilhelm, 2005

A obra realizada em 1952 intitulada "Alegoria às Artes" foi executada no mesmo período da construção da edificação sendo prevista pelo arquiteto Roberto José Goulart Tibau. A intenção do arquiteto em destinar um espaço para a execução do mural é expressa em seu depoimento:

[...] porque quando nós fizemos o projeto, imediatamente vimos que aquela parede tinha um estilo muito bom para se fazer um painel ali e que seria bonito, naquele espírito mesmo de dar uma certa dignidade ao teatro e fazer uma coisa mais vinculada à cultura, à arte mesmo. Então, naquela parede estava previsto o projeto de um painel. (TIBAU In: SANDEVILLE, 1985, p.107)

Por intermédio da Comissão do Convênio Escolar da Prefeitura Municipal de São Paulo - PMSP - foi solicitado a Clovis Graciano, em 1952, em carta ofício no 1882/52 datada de 30 de outubro de 1952 e assinada pelo engenheiro responsável presidente da Pref. da Comissão do Convênio Escolar (C.E.), a realização de um 'painel'. 83

${ }^{83}$ A carta ofício no $1882 / 52$ datada de 30 de outubro de 1952 ofício 1882/52 e endereçada a Clovis Graciano na rua Piauí, SP era referente ao Teatro João Caetano e mencionava como transcrito: Fica V.S. autorizado a executar um painel no Teatro João Caetano, de 5,60 x 3,00 m conforme maquete apresentada, a base de cera (encáustica), pelo preço de $\operatorname{Cr} \$ 45.000,00$ (quarenta e cinco mil cruzeiros) de acordo com a proposta de 29 do corrente, que foi aprovada pelo Sr. Prefeito. O painel deverá ser entregue completamente terminado, até o dia 19 de novembro, p.f. data em que será inaugurado o teatro. Atenciosamente, saudações, Eng. Wether Krause presidente da Pref. C.E. 


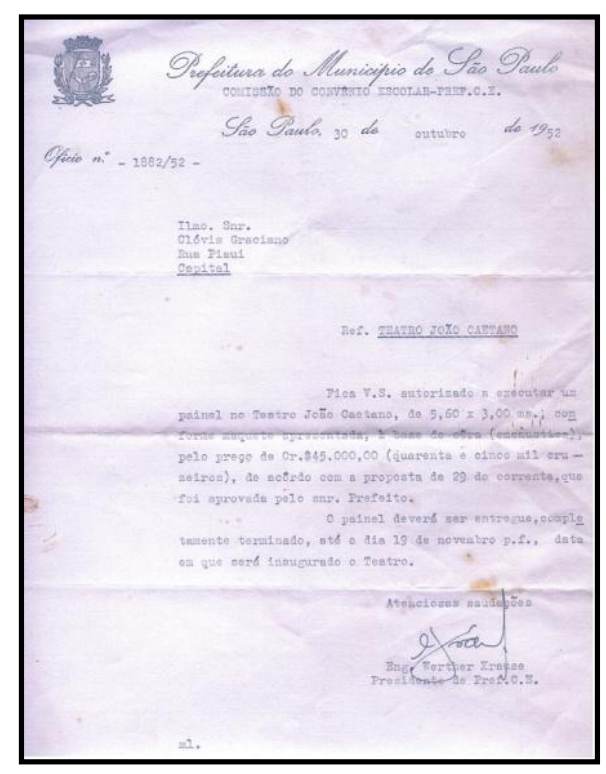

Figura 32 Carta da PMSP- Comissão do Convênio Escolar enviada para Clovis Graciano com a encomenda do mural para o Teatro João Caetano - datada de 30 de outubro de 1952. Fonte: Arquivo do artista, cópia fornecida pela Mª Helena Prudêncio, marchand.

O Teatro na realidade só foi inaugurado em 25 de dezembro de 1952 na administração do Prefeito Engenheiro Armando de Arruda Pereira (de 1951-1953) conforme placa comemorativa colocada no saguão da entrada:

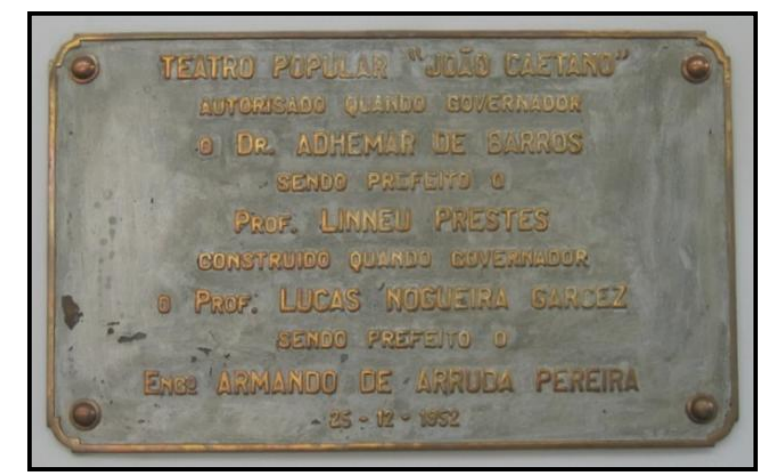

Figura 33 - Placa comemorativa de inauguração do Teatro Foto: $\quad$ Vera Wilhelm, 2005

Em 1951 Clovis Graciano havia recém chegado de Paris, para onde viajou, em 1949, com o prêmio ganho no Salão Nacional de Belas Artes e onde permaneceu durante dois anos se aperfeiçoando e estudando gravura e a técnica de pintura mural. 

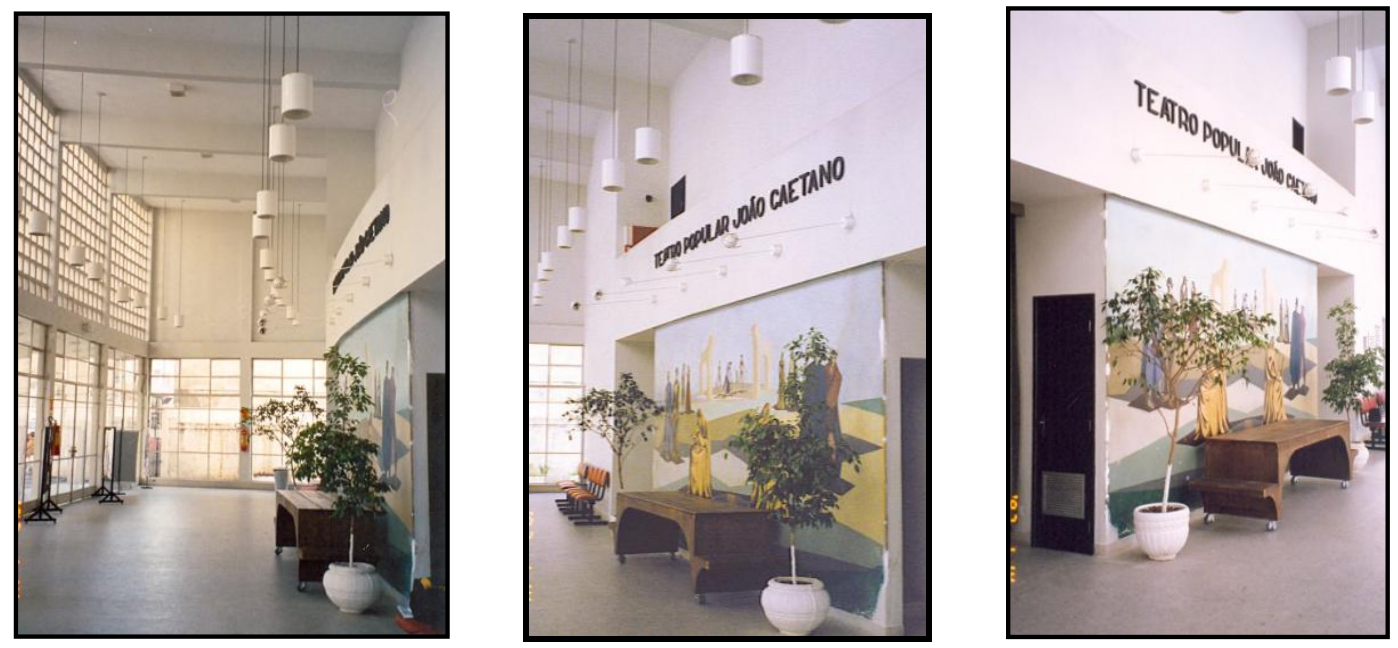

Figuras 34,35 e 36 Saguão de entrada

Foto: Vera Wilhelm, 2005

A obra foi executada no hall de entrada do teatro e pode ser vista diretamente por quem passa na rua e por todos os freqüentadores do teatro. O mural está localizado na parede central do saguão de entrada que separa as duas portas de acesso para a platéia. Esta parede é interna e divide a área do saguão com a escadaria que leva ao piso superior, onde estão as salas da administração e da área técnica do teatro.

O tema do mural está relacionado à cultura como menciona o arquiteto Tibau em seu depoimento, mas principalmente relacionado às Artes e ao Teatro.

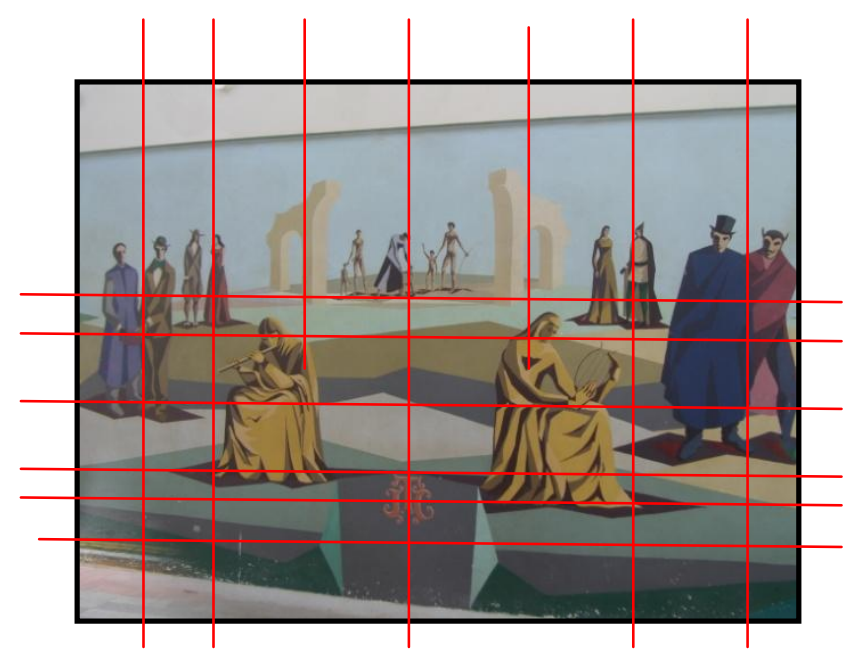

Figura 37 Mural "Alegoria às Artes"

Foto: $\quad$ Vera Wilhelm, 2005

A obra está dividida em planos marcados pelas linhas horizontais e interrompidos por grupos de figuras distribuídos ao longo do mural de forma simétrica demarcando linhas verticais. Essa é uma composição típica e 
característica da produção do artista onde o contraste entre o claro e o escuro marca os planos e a volumetria das figuras.

O artista estabelece uma interação entre a representação do mural e a arquitetura do espaço. As linhas verticais da estrutura da fachada que delimitam os pórticos de acesso e marcam a área de circulação, estão presentes na sequência vertical de figuras e do pórtico de fundo do mural. A demarcação de planos horizontais no espaço arquitetônico é proporcionada pela sequência dos espaços de passagem de pedestres, da rua, da circulação externa do público criada pelos pórticos, da circulação interna, do hall. Os planos horizontais também podem ser vistos nas sobreposições de linhas horizontais e de sequência de distribuição das figuras.

As variações de claro e escuro que assinalam a volumetria das formas no mural se expressam na arquitetura através da contraposição de cheios e vazios e do uso da fachada com tijolo de vidro que permite a entrada de luz natural no ambiente interno durante o dia e na visualização do espaço iluminado a noite.

O jogo de luzes, formas e volumes marcam a obra deste artista e se integram de maneira harmônica no espaço concebido pelo arquiteto. A grande afinidade do artista com o ambiente do teatro ${ }^{84}$ permitiu a integração de sua obra tanto do ponto de vista temático como do ponto de vista espacial com a arquitetura do teatro.

Como menciona Mario de Andrade (1944), em seu ensaio sobre Clóvis Graciano, o decorativismo estava entre as tendências do artista que desenvolvia figurinos de teatro e cenários com ênfase dada a assuntos de ballet.

Os quatro grupos de figuras da arte dramática dispostos em planos diferentes no mural representam as diferentes épocas do teatro. A música é simbolizada pelas duas mulheres, figuras alegorias tocando instrumentos de corda e sopro em primeiro plano, separadas pela boca de cena, os grupos de figuras nas laterais em segundo plano simbolizando o teatro. Na área central do mural ao fundo existe um outro grupo com um religioso e crianças dando destaque para a evangelização, a formação e a história de São Paulo simbolizando a educação através da cultura e da arte.

${ }^{84}$ Clovis Graciano trabalhou fazendo figurinos e cenografia e ganhou, em 1947, o primeiro prêmio do concurso de cenários e vestimentas teatrais promovido pelo Departamento de Imprensa e Propaganda. 
A edificação teve a sua primeira reforma iniciada em 01de novembro de 1976 e que se estendeu até 12 de agosto de 1977, já sob a administração do Departamento de Teatros pertencente à Secretaria Municipal de Cultura criada em 1975.

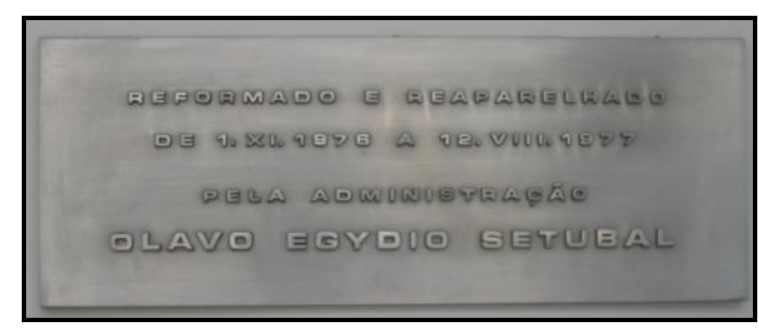

Figura 38 Placa indicativa da reforma executada Foto: $\quad$ Vera Wilhelm, 2005

O Teatro sofreu, além dessa, mais duas outras reformas uma em 1999 e a outra em 2003.

TEATRO JOÃo CAETANO

RESTAURADO, REFORMADO,

AMPLIADO E REEOUIPADO

20-12-99 A 06-11-00

A DMINISTRAÇ̃̃O

CELSO ROBERTO PITTA

Figura 39 Placa indicativa da reforma executada 1999

Foto: Vera Wilhelm, 2005

A história da intervenção de restauração na obra mural de Clovis Graciano deve ser também considerada dentro do contexto da edificação, pois ela constitui um bem integrado. A obra sofreu intervenção de restauração em 1978 feita pelo artista plástico Ícaro realizada logo após a primeira reforma do Teatro ocorrida em 1976, como relata SANDEVILLE (1985).

O mural foi todo repintado e o artista que realizou a repintura deixou registrada a sua intervenção na obra, colocando na área central à direita seu nome e a data da execução, conforme inscrição visível na obra "restauração Ícaro 78". 


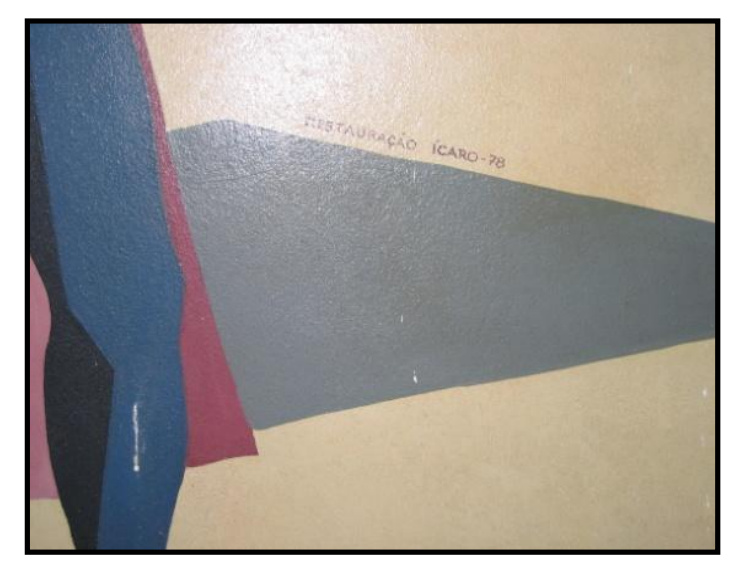

Figura 40 Área com registro da autoria da intervenção Foto: Vera Wilhelm, 2005

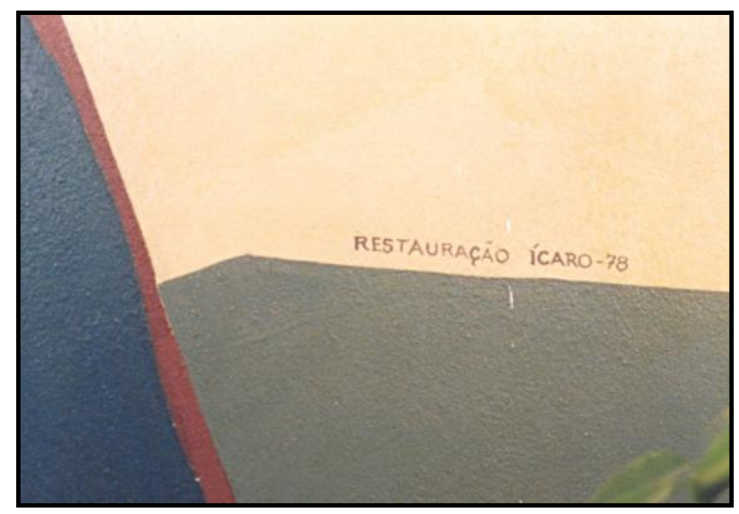

Figura 41 Detalhe do registro e data da autoria da intervenção Foto: Vera Wilhelm, 2005

Segundo depoimento dado pelo arquiteto Tibau e pelo artista ao arquiteto Euler Sandeville Jr., registrado no relatório "A arquitetura dos Teatros Distritais da Prefeitura Municipal de São Paulo," o próprio artista autorizou a realização da obra de "restauração" enquanto ainda era vivo. Não é mencionado, contudo, o porquê da não recuperação da obra pelo próprio artista e, nem mesmo, a relação que o artista Ícaro tinha com Clóvis Graciano.
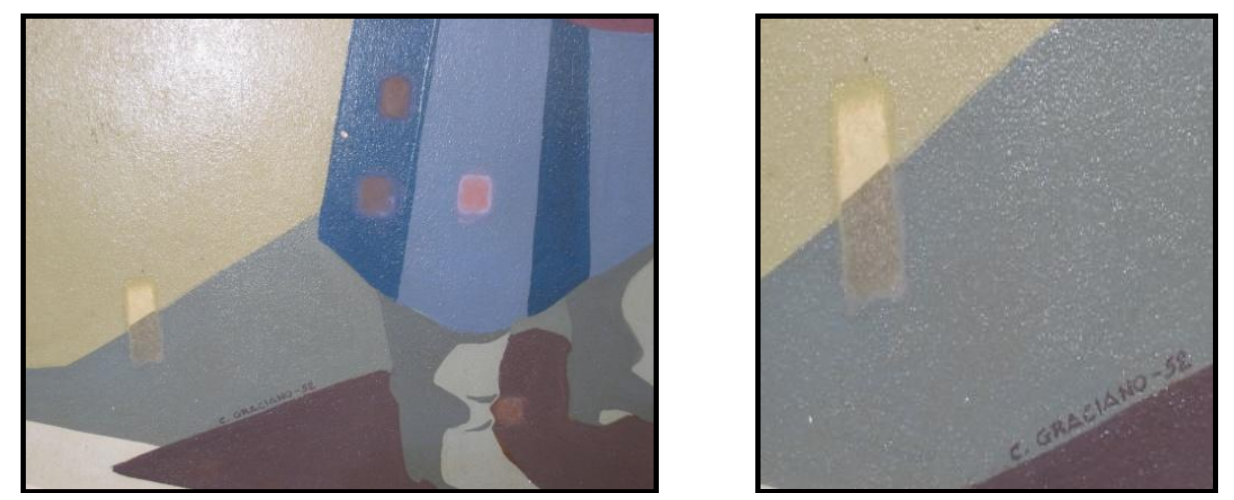

Figura 42 e 43 Área repintada e teste de remoção.

Foto: $\quad$ Vera Wilhelm, 2005 
Na realização da última reforma, em 2003, o mural foi recoberto por uma estrutura composta de chapas de madeira pintadas de branco, que foi posicionada alguns centímetros afastada da parede e que serviu de proteção do mural durante o período de obras. A estrutura só foi retirada em 2005 após o término da reforma do Teatro.

O suporte se encontrava em bom estado de conservação apresentando somente algumas áreas de perdas concentradas junto às bordas, locais propícios a esse tipo de dano físico. Os reparos ainda existentes no mural em algumas áreas foram realizados após a última reforma, em 2005, segundo depoimento da responsável pela administração do teatro ${ }^{85}$ e consistem no preenchimento, de algumas das áreas de perdas, com argamassa e massa fina.
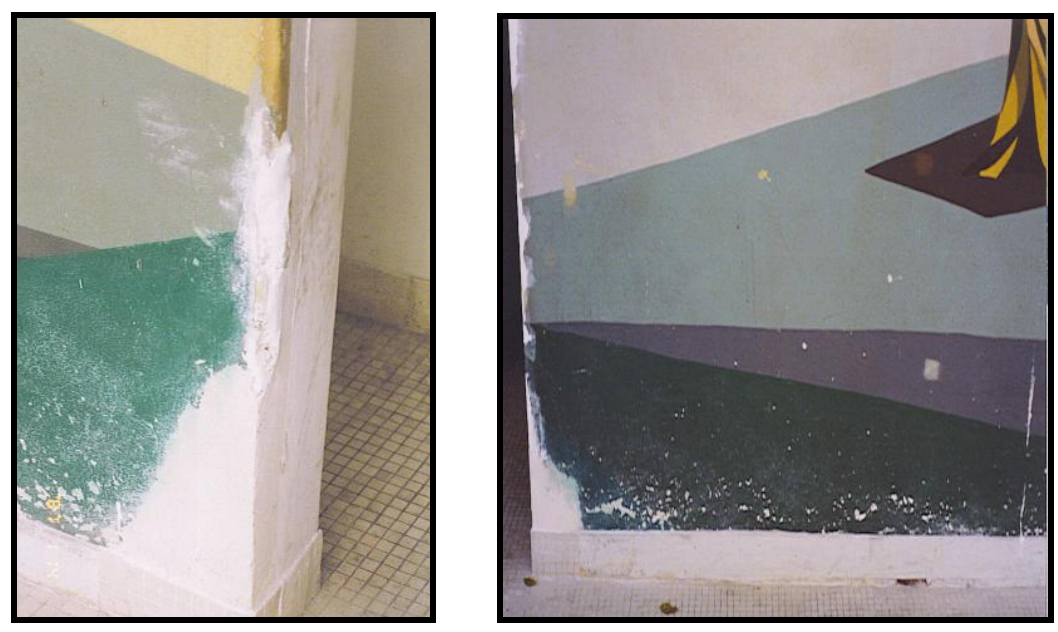

Figura 44 e 45 Detalhes das áreas de perda.

Foto:

Vera Wilhelm, 2005

Na obra de Clóvis Graciano no Teatro João Caetano podemos evidenciar um tipo de procedimento de intervenção, a "repintura", executado em 1978, um período no qual já eram conhecidos os princípios da Carta de Veneza de 1964 e também da moderna Teoria da Restauração, publicada por Cesare Brandi em 1963, que são reiterados na Carta de Restauração Italiana de $1972^{86}$.

Todavia o procedimento revela que a prática de recuperação de obras murais realizada nessa época, aqui entre nós, ainda estava voltada para um tipo de intervenção mais invasiva onde não se consideravam os princípios norteadores de

${ }^{85}$ Depoimento da responsável pela administração do teatro fornecido a autora, em 2005.

${ }^{86}$ A Carta de Restauração de 1972 apresenta as normas para orientação de intervenções de restauração em instituições italianas. 
uma atuação prática introduzidos por Brandi como a distinguibilidade, a mínima intervenção e a reversibilidade.

Nessa década esse tipo de intervenção ainda era feita por pintores de parede, pintores decoradores ou por artistas.

O procedimento de registro com data e nome de quem realizou a obra de restauração já era, porém, uma prática constante a partir do início do século XX na Europa, principalmente na Itália, em obras arquitetônicas, geralmente com a colocação de placas de registro ${ }^{87}$. No Anexo A da Carta de Restauração de 1972 , sobre as Instruções para a Salvaguarda e a Reabilitação das Antiguidades já se mencionava que: "Por fim, será oportuno colocar em todas as zonas restauradas placas com a data, ou gravar siglas ou marcas especiais." (BRANDI, 2004, p. 240)

$\mathrm{Na}$ Carta, no texto do Anexo C, são ainda mencionadas instruções para execução de restaurações pictóricas e escultóricas e as precauções a serem tomadas ao se realizar uma intervenção de restauração: "Uma exigência fundamental da restauração é respeitar e salvaguardar a autenticidade dos elementos constitutivos da obra." (BRANDI, 2004, p. 244)

O caso do mural do teatro é, portanto, um exemplo típico de repintura, de uma intervenção feita em obra, com algum tipo de dano físico (como abrasão, perdas de suporte, etc.) cuja solução adotada foi a mais simples, prática, imediata e de menor custo na recuperação da obra artística.

Geralmente esse tipo de intervenção é realizado sem critérios já que o conceito de restauração não é conhecido ou é equivocadamente interpretado. A manutenção da materialidade da obra, com a possibilidade de reversibilidade da intervenção ou com a preocupação em evidenciar claramente a área de intervenção, distinguindo-a da original, não fizeram parte do conceito de 'restauração' e pode-se constatar que intervenções com essas características se repetirão, ainda por muito tempo, na grande maioria de obras murais decorativas e artísticas executadas nas edificações da cidade.

Elas serão ainda mais evidentes nas obras de Clovis Graciano, tanto nas obras murais como na técnica de óleo sobre tela, em função das suas características formais e compositivas que propiciam e muito a realização desse tipo de intervenção. A simplicidade de traços e composição, a linearidade e estilização das

\footnotetext{
${ }^{87}$ As placas de registro são aquelas que apresentam data, siglas ou marcas especiais que identificam uma intervenção na obra.
} 
figuras humanas, com linhas de desenho marcantes e simplificação de planos através de massas, além de ter uma volumetria criada pelo contraste entre cores e pelo claro escuro, o que permite uma intervenção de repintura e um realce das cores ou mesmo um escurecimento delas.
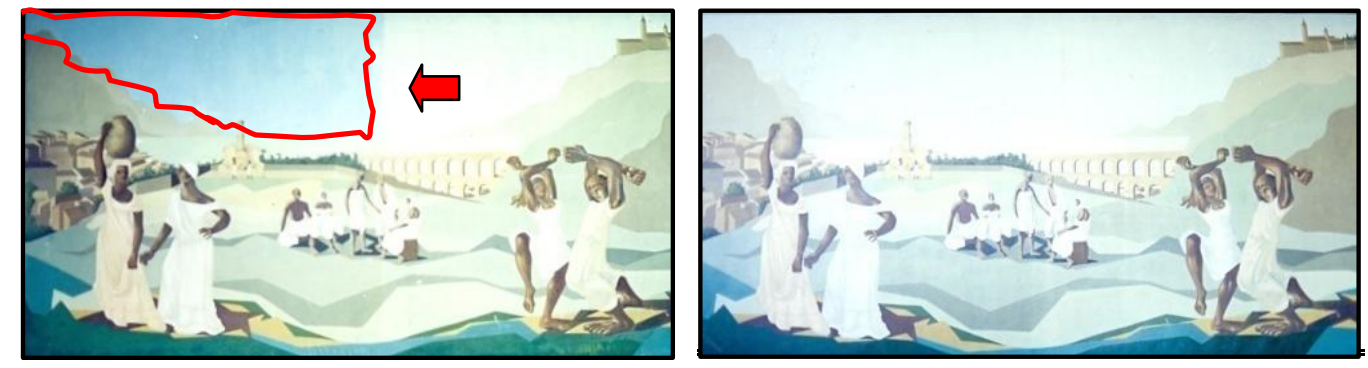

Figura 46 e 47 Detalhe da remoção da área de repintura, óleo s/ tela Clóvis Graciano - Acervo Clube Athlético Paulistano

Foto: Vera Wilhelm, 1993

No ano em que ocorreu a intervenção, 1978, o Departamento do Patrimônio Histórico (DPH), órgão de preservação da cidade de São Paulo com atribuições de identificação, proteção e fiscalização do patrimônio cultural e natural, tinha sido recentemente criado (1975) e não possuía um corpo técnico tão especializado para um suporte dessa natureza. Além disso, a obra só foi tombada em 1992 pela resolução 29/CONPRESP/92 processo nำ 16-003.576-89*78.

Um aspecto interessante a ser considerado na história da intervenção desta obra mural é que a obra, realizada em 1952, se manteve somente 24 anos com a pintura original e a repintura, intervenção feita em 1978, que existe lá atualmente, completou agora em 2010 os seus 32 anos. Portanto, a obra mural do Teatro João Caetano ficou mais tempo sendo reconhecida e apreciada pela sua repintura do que propriamente pela sua materialidade ou condição original. Os tons das cores, evidentes nas 'janelas' abertas para realização de testes de remoção são diferentes daqueles originalmente pintados pelo artista (fig. 42 e 43).

O arquiteto Eduardo Corona comenta na revista "Arquitetura e Decoração" sobre a obra geral do artista.

O trabalho de Clovis Graciano dispensa maiores comentários, pois está realizado dentro daquele senso de unidade que o pintor apresenta em todas as suas pinturas, cujo colorido calmo de tons agradáveis estabelece uma definição plástica ao desenho, que sempre é equilibrado e expressivo. (CORONA, 1954. AD no 08, nov/dez 1954) 
Diante das evidências, torna-se claro que há necessidade de uma reflexão sobre qual postura deve ser adotada em caso de uma futura intervenção de restauração, já que os testes de remoção de repintura, realizados por solicitação do órgão responsável pela preservação foram realizados provavelmente com a intenção de se fazer futuramente uma restauração.

Considerando que a intervenção excede o período de exposição da própria constituição original e material da obra é recomendado que, uma reflexão sobre a remoção ou não desta repintura seja realizada com cautela e juízo crítico, pois ela também já se incorporou a obra e a sua história material, embora os testes de remoção feitos em diferentes áreas evidenciaram a existência da camada pictórica original, nas janelas de prospecção abertas (fig. 42 e 43).

A Carta de Veneza menciona no artigo $11^{0}, 88$ relativo à restauração arquitetônica que:

A contribuição válida de todos os períodos na construção de um monumento deve ser respeitada desde que a unidade de estilo não seja o objetivo da restauração. Quando um edifício inclui a sobreposição de trabalhos de diferentes períodos a revelação de áreas sobrepostas deve ser justificável somente em circunstâncias excepcionais e se o que será removido é de pouco interesse e se o material que será evidenciado for de grande interesse e valor histórico, arqueológico e estético e seu estado de preservação for suficientemente bom para justificar a ação. A avaliação da importância dos elementos envolvidos e da decisão do que será destruído não pode ser somente responsabilidade individual. (CARTA DE VENEZA, 1964, art. 11ํㅡㄹ tradução nossa).

Nos princípios do ICOMOS ${ }^{89}$ também é feito menção ao tema já especificamente para as pinturas murais:

${ }^{88}$ Carta Internacional de Conservação e Restauração de Monumentos e Sítios (Carta de Veneza 1964) disponível em:<http://www.international.icomos.org/charters/venice e.htm>. ARTICLE 11. "The valid contributions of all periods to the building of a monument must be respected, since unity of style is not the aim of a restoration. When a building includes the superimposed work of different periods, the revealing of the underlying state can only be justified in exceptional circumstances and when what is removed is of little interest and the material which is brought to light is of great historical, archaeological or aesthetic value, and its state of preservation good enough to justify the action. Evaluation of the importance of the elements involved and the decision as to what may be destroyed cannot rest solely on the individual in charge of the work."

${ }_{89}$ Princípios do ICOMOS para a Preservação e Conservação - Restauração das Pinturas Murais (2003), disponível em:<http://www.international.icomos.org/charters/wallpaintings e.htm>

"Natural ageing is a testimony to the trace of time and should be respected. Irreversible chemical and physical transformations are to be preserved if their removal is harmful. Previous restorations, additions and over-painting are part of the history of the wall painting. These should be regarded as witnesses of past interpretations and evaluated critically".(ICOMOS 2003, ARTICLE 5) 
O envelhecimento natural é um testemunho da passagem do tempo e deve ser respeitado. Devem ser preservadas as transformações químicas e físicas, caso a sua remoção seja prejudicial. As restaurações anteriores, adições e sobrepinturas fazem parte da história da pintura mural. Devem ser encarados como testemunhos das interpretações passadas e avaliados criticamente. (ICOMOS 2003, art. 05, tradução nossa)

A revelação de pinturas murais exige o respeito pela situação histórica e a avaliação sobre o que pode estar perdido. Esta operação só deve ser executada depois de investigações preliminares da sua condição, extensão e valor e quando for possível sem a ocorrência de danos. As pinturas recentemente reveladas não devem ficar expostas a condições desfavoráveis. (ICOMOS, 2003, art. 05, tradução nossa).

A avaliação exige, portanto, uma decisão conjunta de profissionais que possam, em suas respectivas áreas de atuação, auxiliar na melhor fundamentação para a opção de intervenção na obra.

Estudo de caso nำ2: Edifício Bienal.

O segundo caso a ser estudado é a obra mural de Clovis Graciano executada no Edifício Bienal localizado a Rua João Lourenço no 797 - bairro de Vila Nova Conceição em São Paulo, capital.

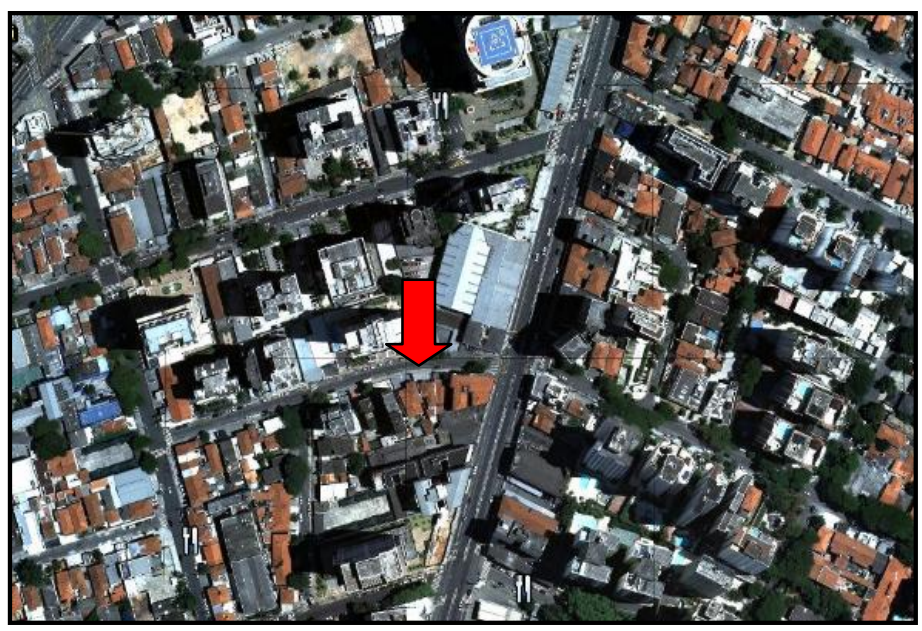

Figura 48 Localização do Edifício Bienal - Vila Nova Conceição

Rua João Lourenço esquina Av. Santo Amaro

Fonte: Google Earth Plus, 2009

"Uncovering of wall paintings requires the respect of the historic situation and the evaluation of what might be lost. This operation should be executed only after preliminary investigations of their condition, extent and value, and when this is possible without incurring damage."(ICOMOS 2003, ARTICLE 5) 
A obra foi realizada na edificação projetada pelo arquiteto carioca Abelardo $R$. de Souza, que teve importante atuação em São Paulo na década de 1940 a 1950, junto com Hélio Duarte.

$\mathrm{O}$ arquiteto realizou outras obras de significativa expressão na arquitetura paulistana, como o projeto do Edifício Nações Unidas na Avenida Paulista no 648 cuja construção se iniciou em 1958 e hoje é um imóvel protegido legalmente pelo CONPRESP $^{90}$ e que também apresenta um mural de Clóvis Graciano, mas na técnica de cerâmica.

O Edifício Bienal de Abelardo R. de Souza, no bairro de Vila Nova Conceição, não recebe proteção legal de nenhum dos órgãos de preservação (municipal, estadual ou federal).

A edificação composta de três pavimentos além do andar térreo foi projetada, em 1955, para ser um imóvel de uso misto residencial e comercial, num bairro residencial que estava em expansão ao longo da antiga Estrada de Santo Amaro, hoje denominada Avenida Santo Amaro.

No térreo do edifício parte da área ocupada é de uso comercial, no primeiro pavimento o uso é misto residencial e comercial e os outros dois pavimentos são exclusivamente de uso residencial, área destinada a apartamentos.

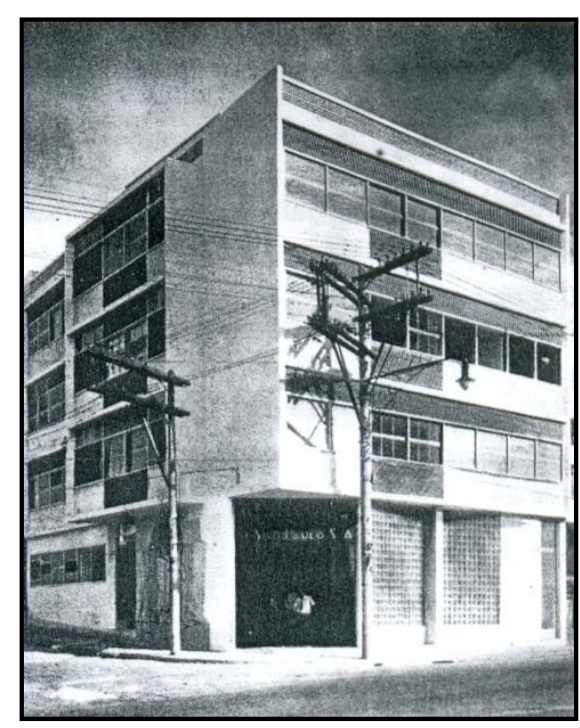

Figura 49 Vista de Edifício Bienal 1955

Fonte: Revista AD Arquitetura e Decoração maio/junho, 1955 nำ 11

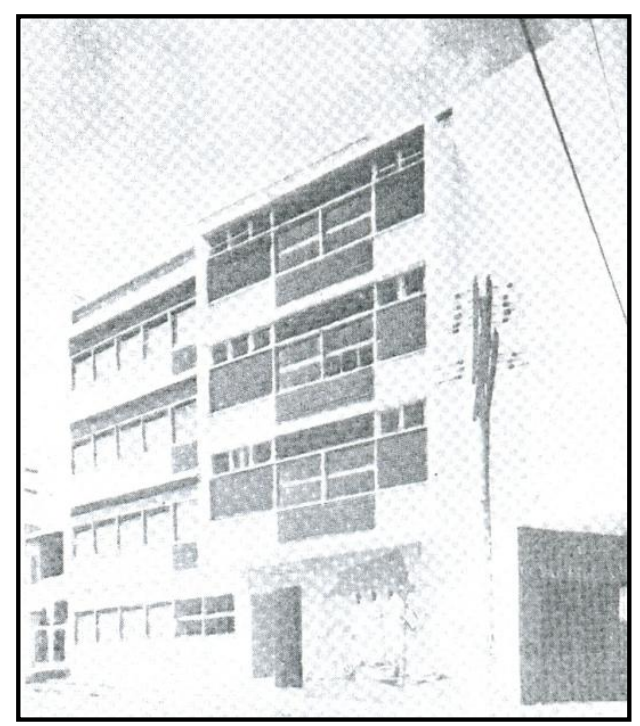

Figura 50 Vista lateral do Edifício Bienal 1955

Fonte: Revista AD Arquitetura e Decoração maio/junho 1955, nำ11

90 Resolução 26/Conpresp/04 abertura de processo de tombamento dos imóveis enquadrados ou propostos como Zonas Especiais de Preservação Cultural (ZEPEC) de que trata a Lei no 13885 de 25 de agosto de 2004, pelo proc. 2005-0.091880-1. 


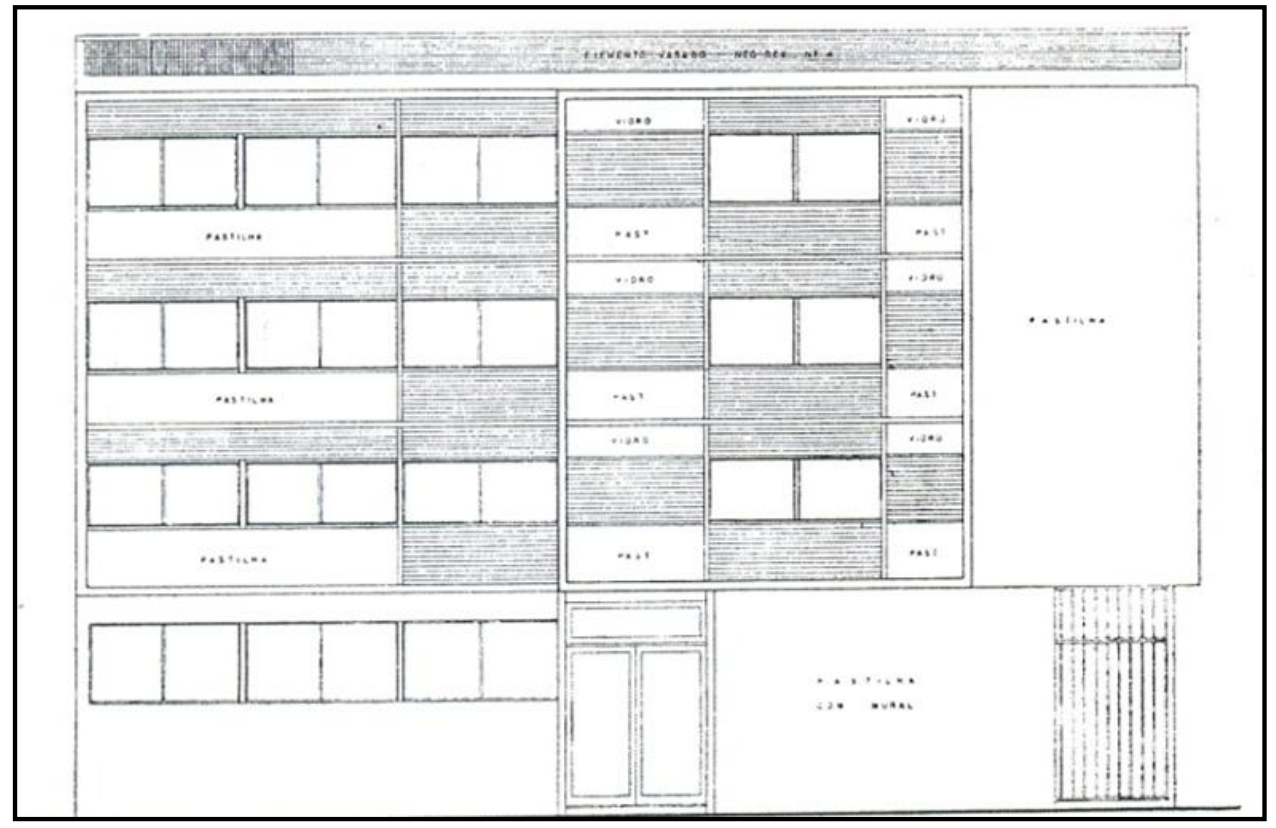

Figura 51 Fachada da Rua São Lourenço 1955

Fonte: Revista AD Arquitetura e Decoração maio/junho 1955 nำ 11

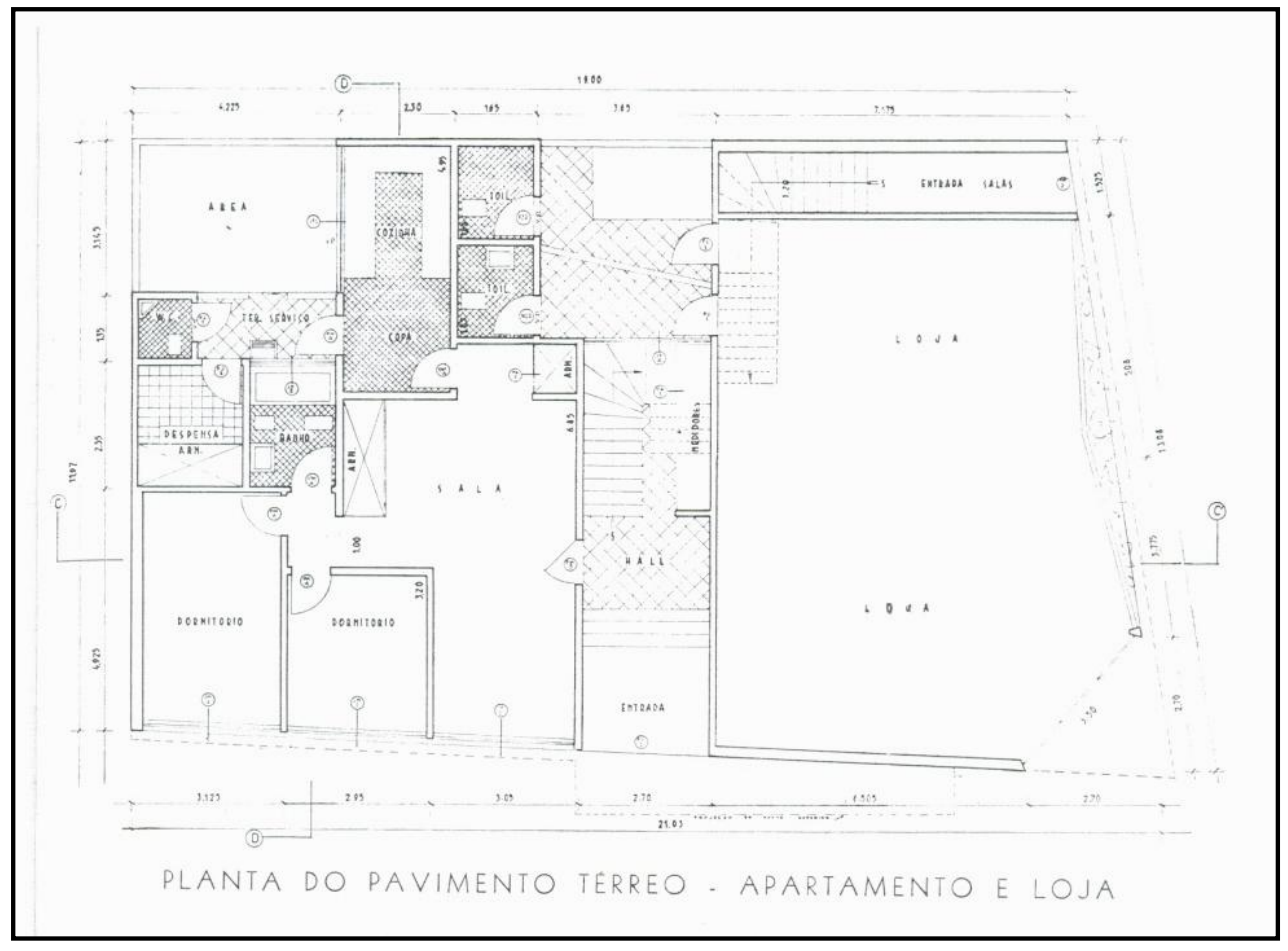

Figura 52 Planta do pavimento térreo apartamento e loja

Fonte: $\quad$ Revista AD Arquitetura e Decoração maio/junho 1955 № 11 
PLANTA DO 1.0 PAVIMENTO - APARTAMENTO E ESCRITORIOS

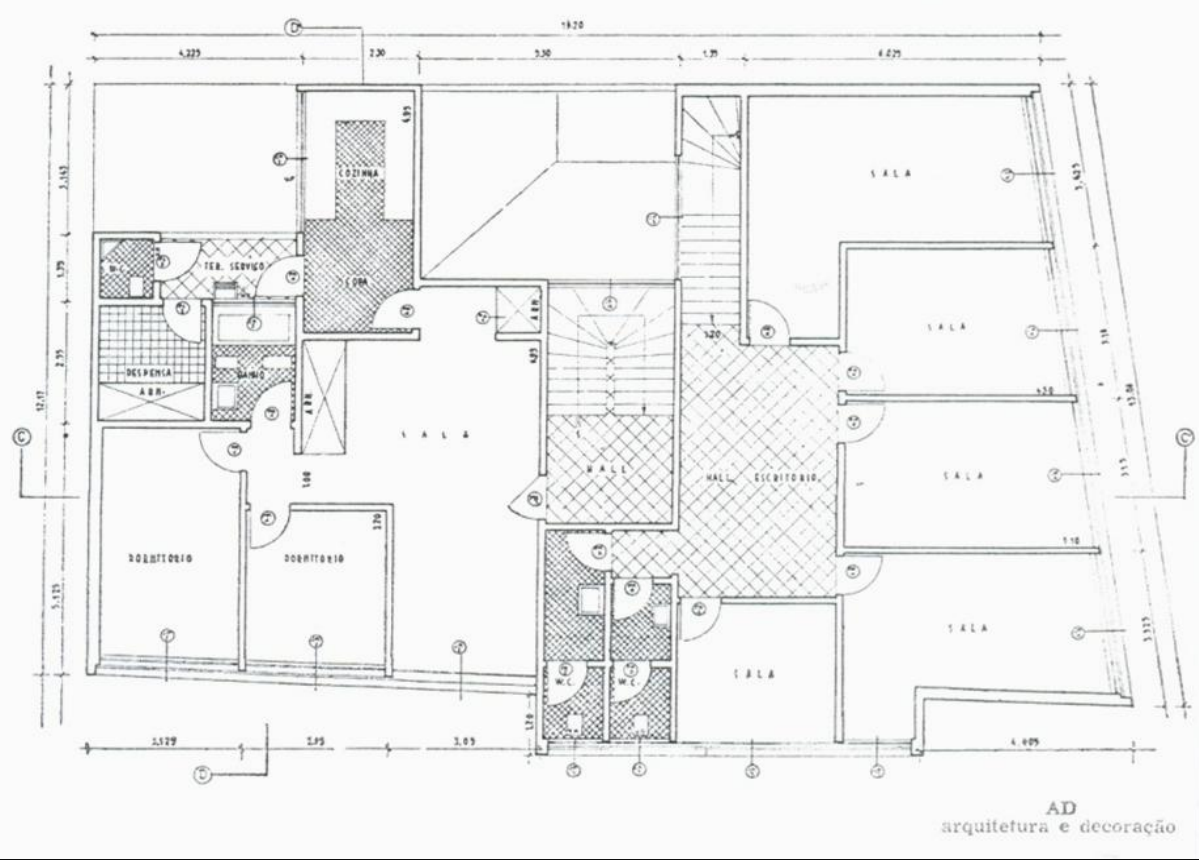

Figura 53 Planta do 1 pavimento apartamento e escritório

Fonte: Revista AD Arquitetura e Decoração maio/junho 1955, no 11

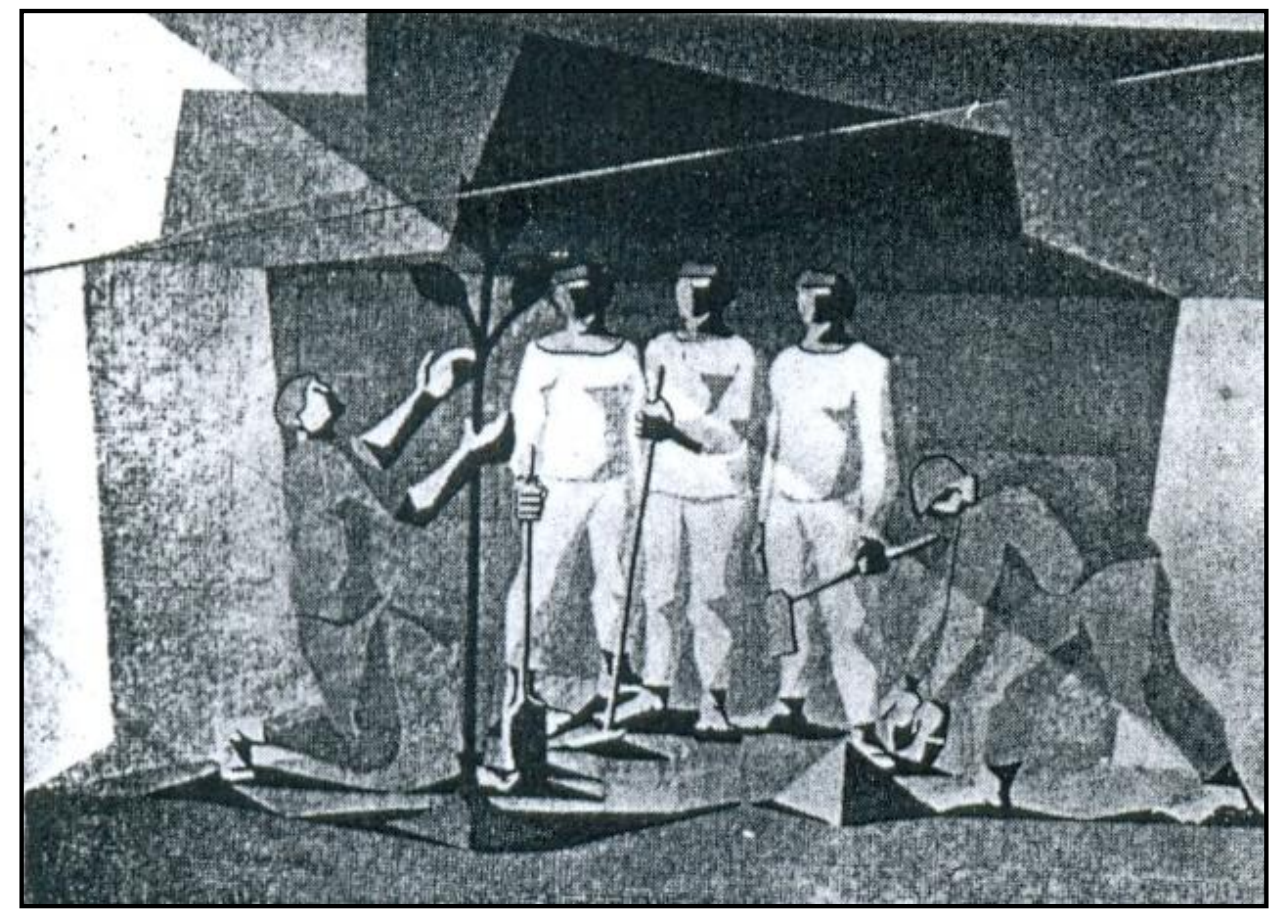

Figura 54 Vista do mural na fachada da Rua João Lourenço

Fonte: $\quad$ Revista AD Arquitetura e Decoração maio/junho 1955 nํ 11 


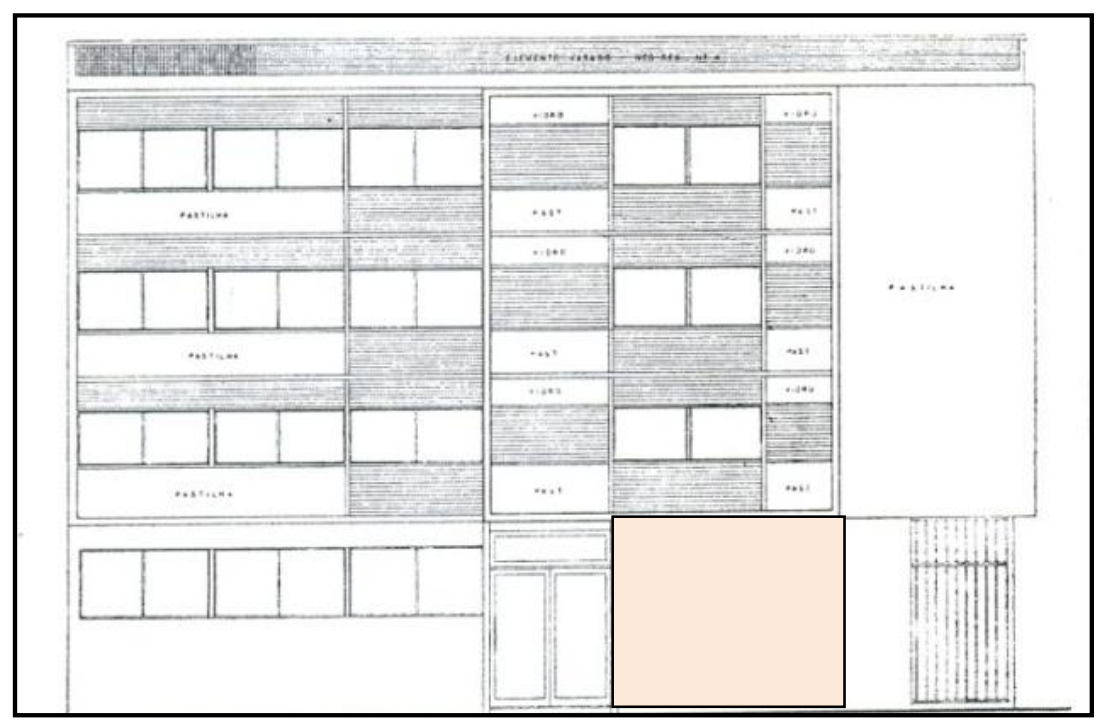

Figura 55 Área destina ao mural na fachada da Rua João Lourenço

Fonte: Revista AD Arquitetura e Decoração maio/junho 1955 ํำ 11

A obra de Clovis Graciano, sem titulo, localizada na lateral da edificação na Rua João Lourenço, medindo $393 \times 664 \mathrm{~cm}$, foi executada com o mesmo material do revestimento da fachada da edificação, isto é pastilhas de cerâmica coloridas de tonalidade pastel, que se integram ao colorido da fachada e a obra apresenta assinatura no canto inferior direito.

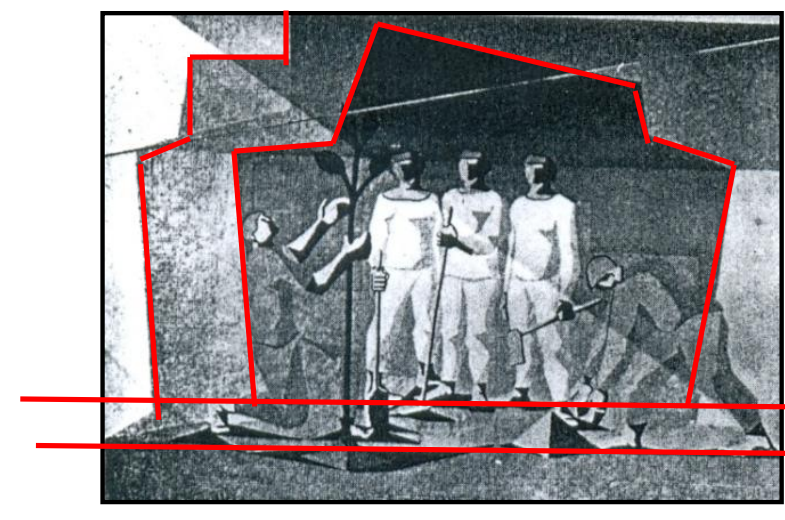

Figura 56 Mural na Rua João Lourenço

Fonte: Revista AD Arquitetura e Decoração maio/junho 1955 nำ 11

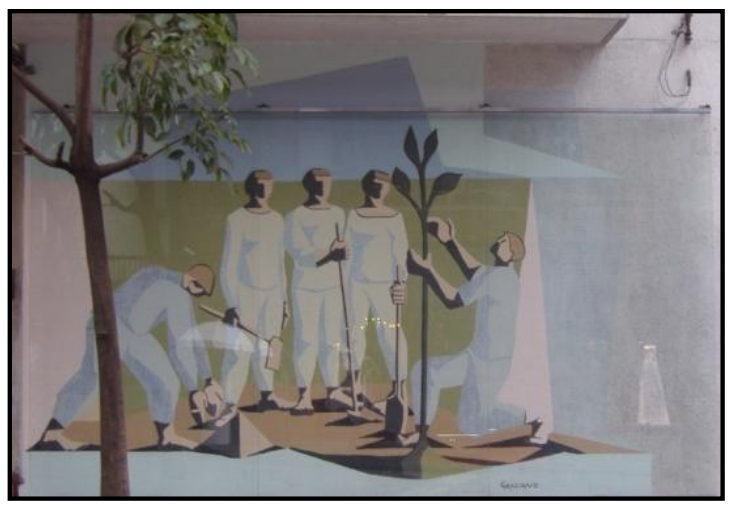

Figura 57 Mural na Rua João Lourenço Foto: Vera Wilhelm, 2009

A composição segue o mesmo padrão das obras de Graciano, porém, neste caso, com uma demarcação de planos não apenas através de linhas horizontais, mas evidenciados pela seqüência de formas e cores no plano vertical contrastando com as figuras distribuídas em dois planos e de maneira simétrica.Os dois grupos de figuras de trabalhadores rurais participam do plantio de uma muda de árvore/café, as 
figuras em primeiro plano executam e os outros em segundo plano observam o plantio.

O prédio se localiza em terreno de esquina com vistas para a Rua João Lourenço e para a Avenida Santo Amaro, via de circulação aberta em fins dos anos de 1940 e que com o decorrer dos anos e o crescimento da cidade sofreu aumento do fluxo viário, a criação do corredor de ônibus Bandeira-Santo Amaro, nas décadas finais do século $X X$, o que provocou um processo de deterioração e conseqüente desvalorização da área.

Somente em meados dos anos 2000 é que a área começou a tomar outra feição em função da expansão comercial e da valorização da região do Itaim, Vila Olímpia e Vila Nova Conceição, com a construção de novos prédios, a reforma de antigos pontos comerciais e também com a criação da lei "cidade limpa" em 2007, que permitiu a despoluição visual das fachadas ao longo da Avenida Santo Amaro e em vários casos, nos imóveis foi feito um investimento na sua recuperação.

O mural do Edifício Bienal se encontrava até 2003 em bom estado de conservação, apesar da existência de áreas com intervenção, aplicação de cimento e perda de pastilhas perto da assinatura. O mural foi pichado por volta do ano 2003/2004 e assim permaneceu até final de 2007.

No ano de 2006 o edifício sofreu uma pintura na cor azul claro na área inferior da fachada da Avenida Santo Amaro, onde, ainda hoje existe um estabelecimento comercial, um bar. A pintura parcial da fachada, somente no andar térreo foi realizada antes da intervenção na obra mural que ocorreu em 2007. A pintura integral do imóvel foi realizada em 2009 com uma cor bege sobre as pastilhas branca/cinza do edifício.

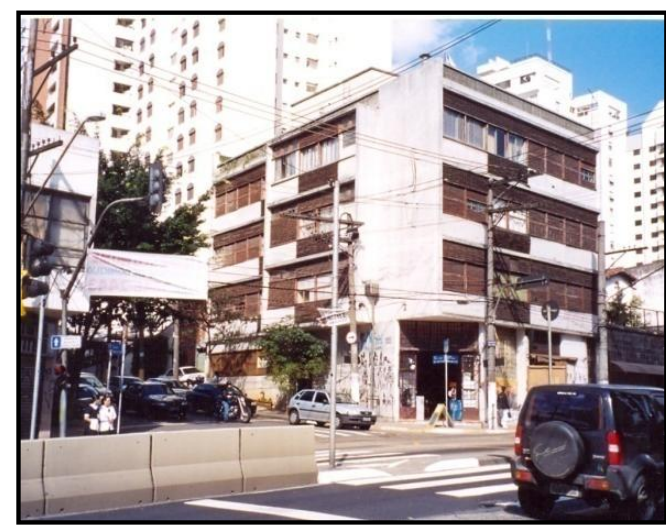

Figura 58 Edifício Bienal Vista da Av. Santo Amaro

Foto: Vera Wilhelm, 2005

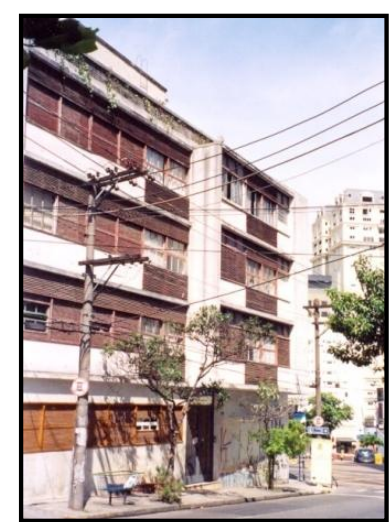

Figura 59 Edifício Bienal Vista da Rua João Lourenço Foto: Vera Wilhelm, 2005 


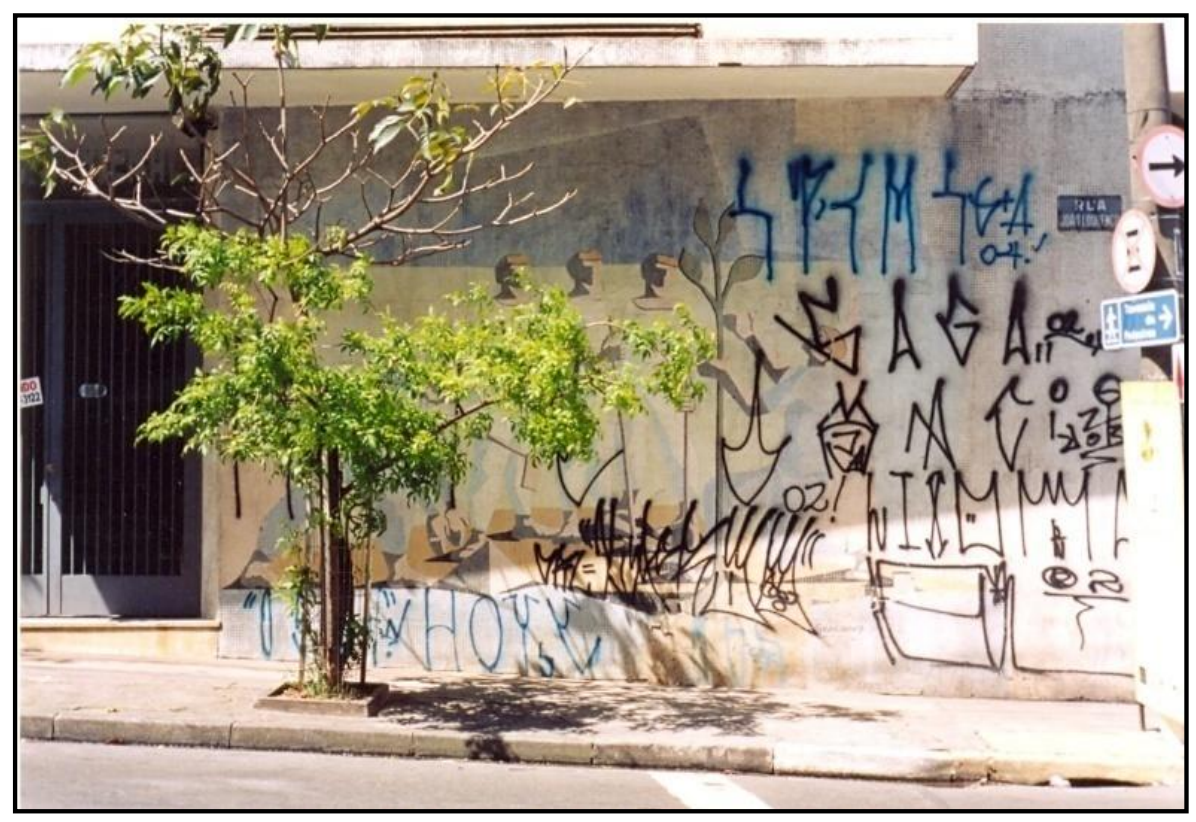

Figura 60 Edifício Bienal Obra de Clovis Graciano Pichada entre 2003 /2004 Foto: $\quad$ Vera Wilhelm, 2005

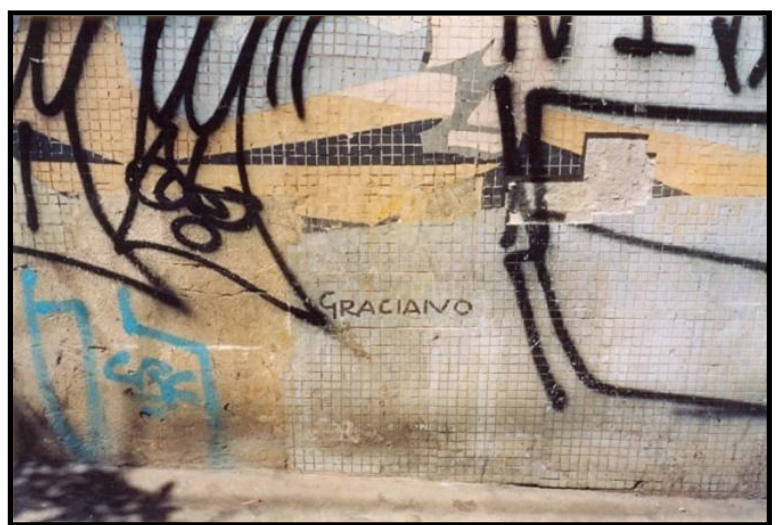

Figura 61 Edifício Bienal. Detalhe da área de perda Foto: Vera Wilhelm, 2005

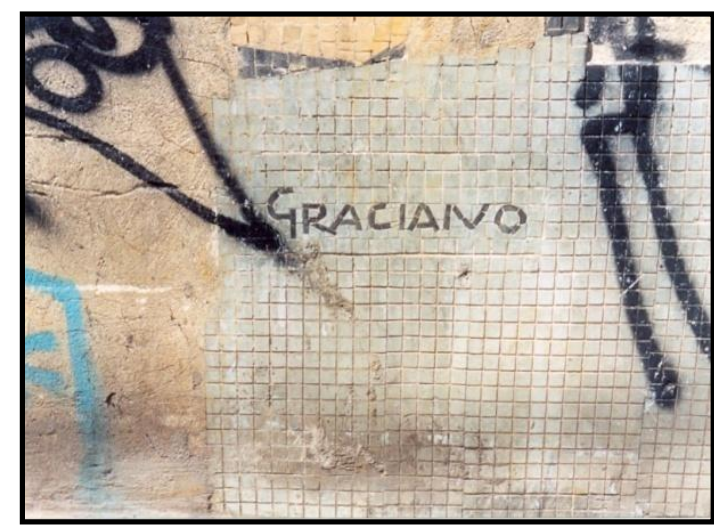

Figura 62 Edifício Bienal. Detalhe da assinatura Foto: Vera Wilhelm, 2005

Antes de 2003 o mural sofreu uma intervenção com um nivelamento feito com a argamassa em uma área de perda próxima à assinatura. As figuras acima mostram a situação do mural entre os anos de 2003 e 2004, todo pichado e com perdas de pastilhas na área próxima à assinatura tornando-o quase irreconhecível na fachada, pois as suas cores eram em tons claros e suaves.

A obra de Clovis Graciano nesta edificação sofreu intervenção por iniciativa de fontes externas aos condôminos do edifício, sendo patrocinada por um comerciante que também realizava um investimento no imóvel na esquina oposta ao edifício. 
As medidas adotadas pelos proprietários do estabelecimento comercial para a 'recuperação' do mural pichado foram feitas com o intuito de melhorar a aparência estética e a visibilidade do local e destacar o estabelecimento comercial que ali se instalava. As figuras abaixo apresentam as intervenções de 'restauração' realizadas no mural em fins de 2007.

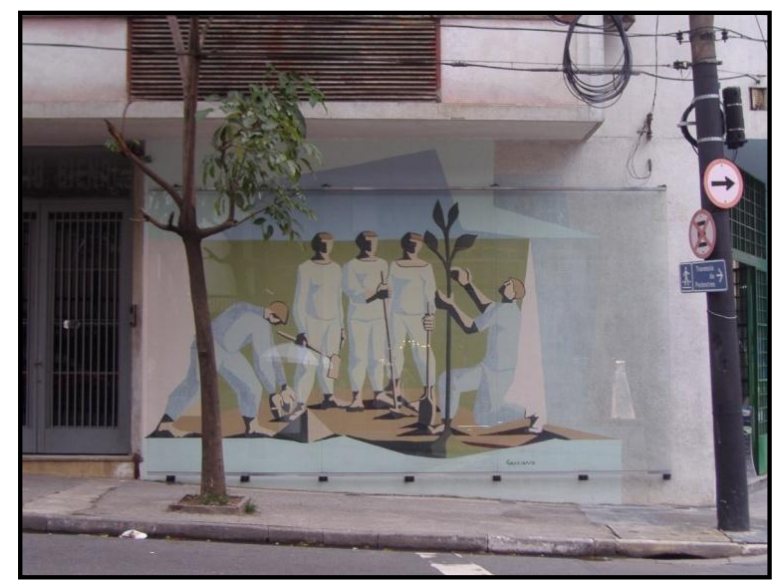

Figura 63 Intervenção de repintura realizada em dez. 2007 Foto: Vera Wilhelm, 2008
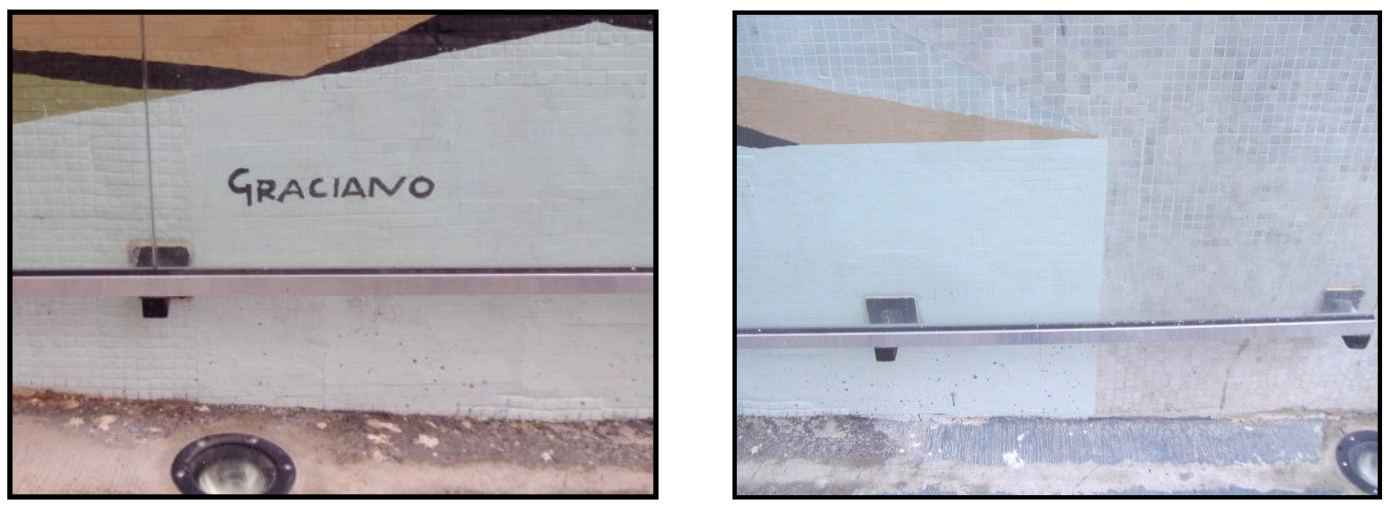

Figuras 64 e 65 Detalhes das áreas repintadas

Foto: Vera Wilhelm, 2008
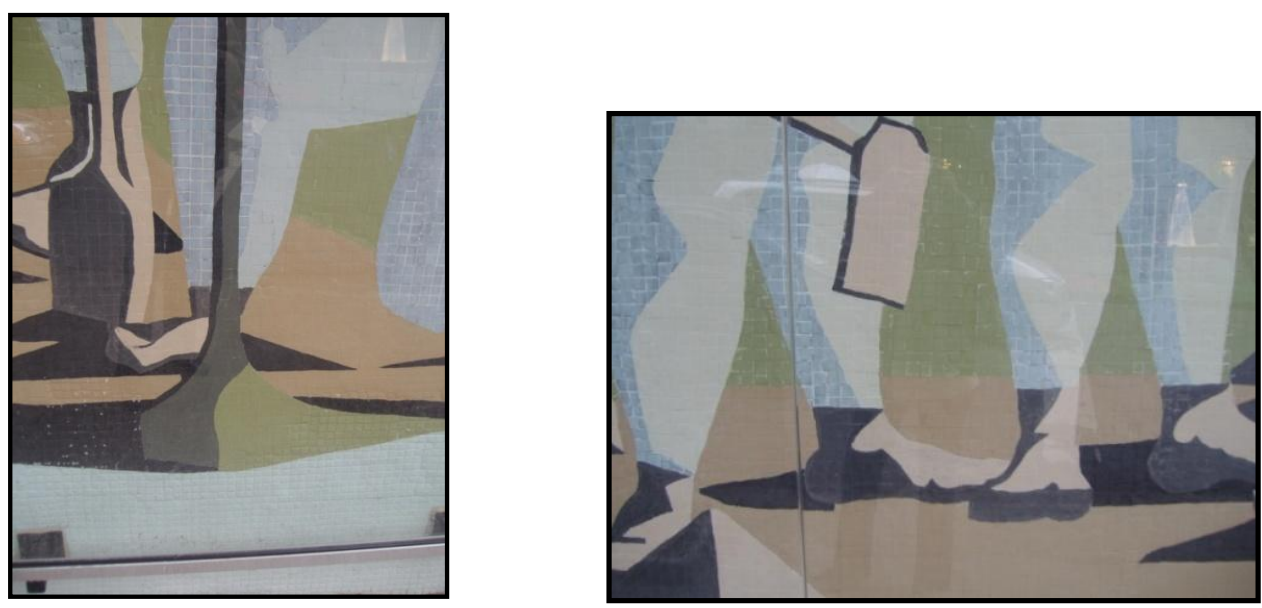

Figura 66 e 67 Áreas repintadas e com rejunte diferenciado do restante da superfície original Foto: Vera Wilhelm, 2008 
Ainda realizando a pesquisa sobre a obra encontramos na internet ${ }^{91}$ um artigo que ilustra a visão ainda equivocada das pessoas sobre o processo de restauração.

A 'recuperação' da visibilidade da obra não demonstra necessariamente a execução de procedimentos mais condizentes com a situação e/ou princípios de restauração ou mesmo que o material mais adequado tenha sido empregado.

Segue abaixo o comentário encontrado em site da internet:

Clóvis Graciano: restauração vitoriosa!!!!

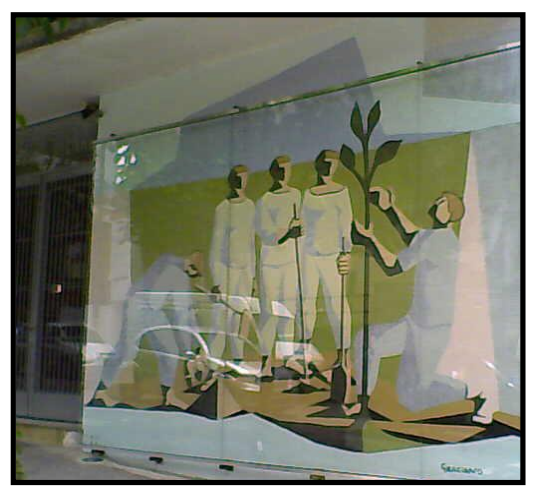

A história fantástica de recuperação da obra de Graciano ainda não acabou: menos de uma semana após receber a mensagem alvissareira de Dona Joyce, ela tornou a me informar e enviar novas fotos do painel, já com a placa de proteção sobre o painel de Clóvis Graciano. Nota DEZ!!! O trabalho de recuperação e de aplicação da tela protetiva foi realizado com muita competência por Arthur Caliman, um estilista consagrado e profissional de múltiplos talentos. (H.G. 2007)

Figura 68 Detalhe de intervenção no mural Foto: Vera Wilhelm, 2008

A obra mural executada na fachada da edificação não comprometeu a função nem o uso do edifício, que se manteve o mesmo, comercial e residencial, ao longo de vários anos.

Apesar de ter sofrido, anteriormente, uma pequena intervenção de nivelamento realizada em algumas áreas de perda pode-se dizer que o mural estava praticamente em bom estado até sofrer atos de vandalismo e pichação.

O processo de intervenção realizado no mural foi feito antes da execução do trabalho de recuperação do edifício. Tendo em vista que o tipo de intervenção deveria ter sido aproximadamente o mesmo, incluindo consolidação do reboco e de pastilhas, preenchimento de áreas de perda, refazer rejunte e limpeza das pastilhas da fachada e do mural, pode-se dizer que não houve um planejamento e nem um trabalho integrado.

Além disso, a obra mural, por estar localizada na área externa e inferior do edifício, está sujeita a eventuais respingos de tintas vernizes e produtos

\footnotetext{
${ }^{91}$ Informação disponível em:<http://mosaicosdobrasil.tripod.com/id38.html>. Acesso em: 20 nov.2009.
} 
eventualmente usados no resto da fachada, caso o mural não fosse previamente protegido antes da execução de uma obra na edificação. Esta proteção do mural para a intervenção na fachada não ocorreu, mesmo já tendo sido ele restaurado.

Verificou-se que o processo ocorreu de forma inversa, pois a intervenção não foi pensada como uma intervenção do conjunto, prédio/ fachada e obra.

Ela foi resultado de um interesse externo com uma intenção claramente de valorização da fachada para que o ponto comercial onde a empresa havia se instalado, na esquina oposta, não fosse prejudicado pela aparência de decadência do local, atribuída às pichações realizadas na parede do edifício sobre a obra de Clovis Graciano.

Esse é um exemplo claro de intervenção feita com a iniciativa repleta de "boas intenções" em recuperar tanto o local quanto a obra, mas que acabou gerando, além da repintura, uma seqüência de procedimentos equivocados.

A obra incentivou os moradores a investir na reforma do edifício também de maneira mais simples, usando a pintura como recurso rápido e de menor custo, sem considerar a possibilidade de uma limpeza de fachada, das pastilhas e recuperação do rejunte, uma prática que tem sido recentemente já bastante utilizada em inúmeros prédios em São Paulo e que seria uma alternativa mais condizente com a manutenção das características materiais da obra, que até então não havia sofrido grandes alterações.

A recuperação da fachada foi iniciada em 2008, após o término da obra do mural e foi executada por uma empresa especializada em manutenção de fachadas $^{92}$.

Segundo o depoimento do síndico ${ }^{93}$ seria feita a pintura da fachada e não a limpeza das pastilhas cerâmicas, pois o empresa mencionou que não compensaria fazer a limpeza. Atualmente o edifício já se encontra todo repintado na cor bege diferentemente da cor original das pastilhas, o branco/cinza, rosa e azul.

\footnotetext{
${ }^{92}$ A empresa Cleaner Manutenção e Pintura Ltda está Localizada na Rua João Pais, 102 - Jardim Petrópolis - São Paulo - SP, CEP 04603-030 Fone: 5094-1486 Fax: 5542-0435. Endereço eletrônico: http://www.cleanerpinturas.com.br

${ }_{93}$ Depoimento do síndico Sr. Luis Fernando dado a autora em 2008.
} 


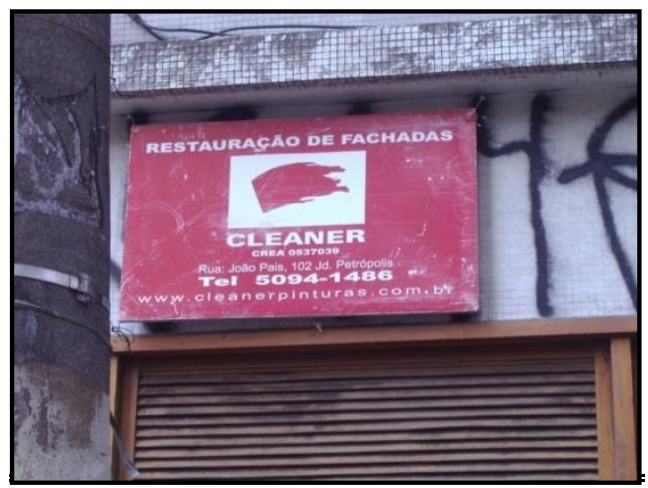

Figura 69 - Placa da empresa que executou a recuperação da fachada no edifício Bienal Foto: $\quad$ Vera Wilhelm, 2008

É interessante salientar que a mesma empresa, segundo consta no seu respectivo site, realizou a limpeza das fachadas de um edifício tombado ${ }^{94}$ e que apesar do conhecimento de determinados cuidados exigidos com uma edificação protegida por lei a postura adotada fugiu totalmente à linha da mínima intervenção.

Independentemente do edifício Bienal não ser um bem tombado, empresa poderia ter adotado o mesmo tipo de procedimento de manutenção de fachada condizente com o tipo de material, já que ficou evidente uma atenção especial ao mural.

Isso demonstra que existe uma variação grande de procedimentos e que a conduta nem sempre se mantém a mesma, fica a critério das necessidades da obra, do cliente ou mesmo do próprio executor do serviço, sendo importante a conscientização e mesmo a orientação daqueles que usufruem do espaço onde a obra se encontra, para que a intervenção mais adequada possa ser realizada.

A intervenção no mural também teve como medida preventiva a criação de um anteparo de proteção da obra contra eventuais pichações ou outros tipos de vandalismo. O anteparo colocado é uma espécie de parede de vidro composta por várias placas estruturadas com perfis de alumínio na parte inferior e superior fixados com espaçamento regular na própria fachada e distantes cerca de 10 a $15 \mathrm{~cm}$ da parede do edifício. A proteção colocada impede a visão clara por causa do reflexo causado, além de ter perfurado em vários pontos a fachada que até então tinha sua superfície preservada, apesar das pichações e de algumas áreas de perda no mural.

\footnotetext{
${ }^{94}$ A empresa realizou a limpeza das fachadas e o rejunte das pastilhas no Conjunto Nacional como exposto no item: Como recuperar uma fachada de pastilhas, no site da própria empresa, com foto do edifício do Conj. Nacional disponível em:<http://www.cleanerpinturas.com.br/servico.html> e informações Disponível em:<http://www.cleanerpinturas.com.br/curriculo.html>. Acesso em: 15 abr. 2011.
} 
Outro elemento não pertencente à obra, mas inserido na intervenção foi a iluminação do mural feita com peças colocadas no chão, na calçada, próximas ao mural evidenciando a obra, agora sem as pichações.

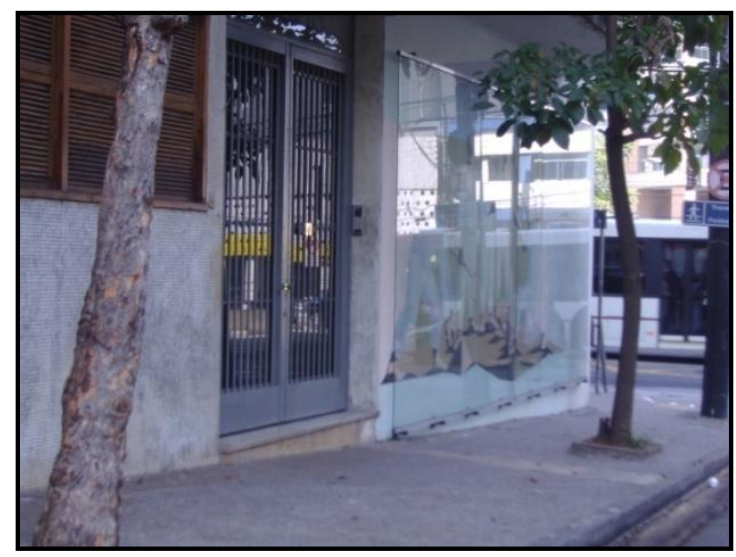

Figura 70 - Vista da proteção de vidro colocada no mural Foto: Vera Wilhelm, 2008
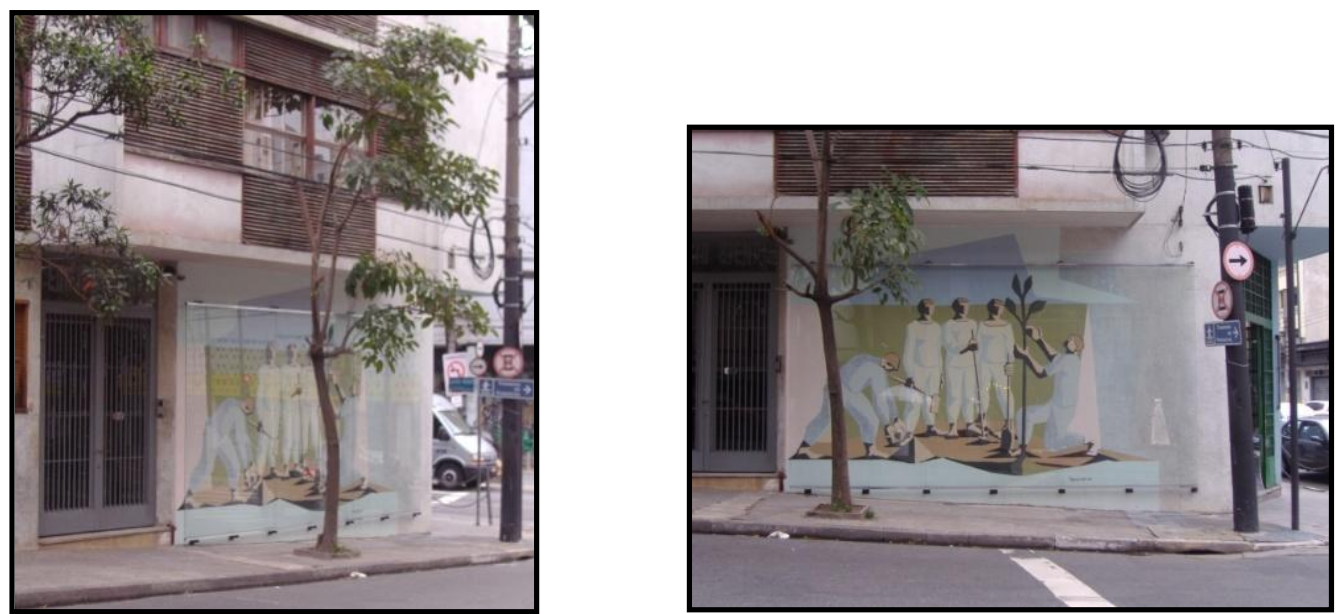

Figura 71 e 72 Vista da proteção de vidro colocada no mural Foto: $\quad$ Vera Wilhelm, 2008

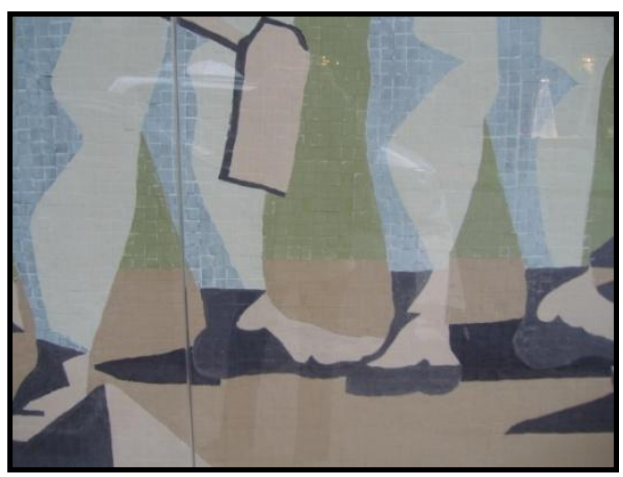

Figura 73 Detalhes da repintura no mural Foto: Vera Wilhelm, 2008

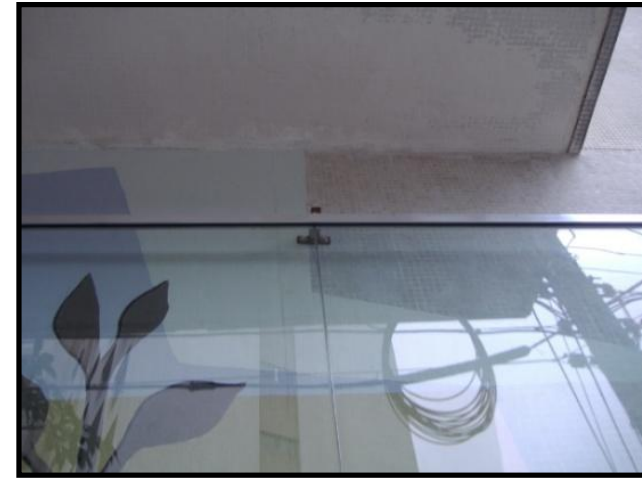

Figura 74 Vista da proteção de vidro colocada no mural Foto: Vera Wilhelm, 2008 

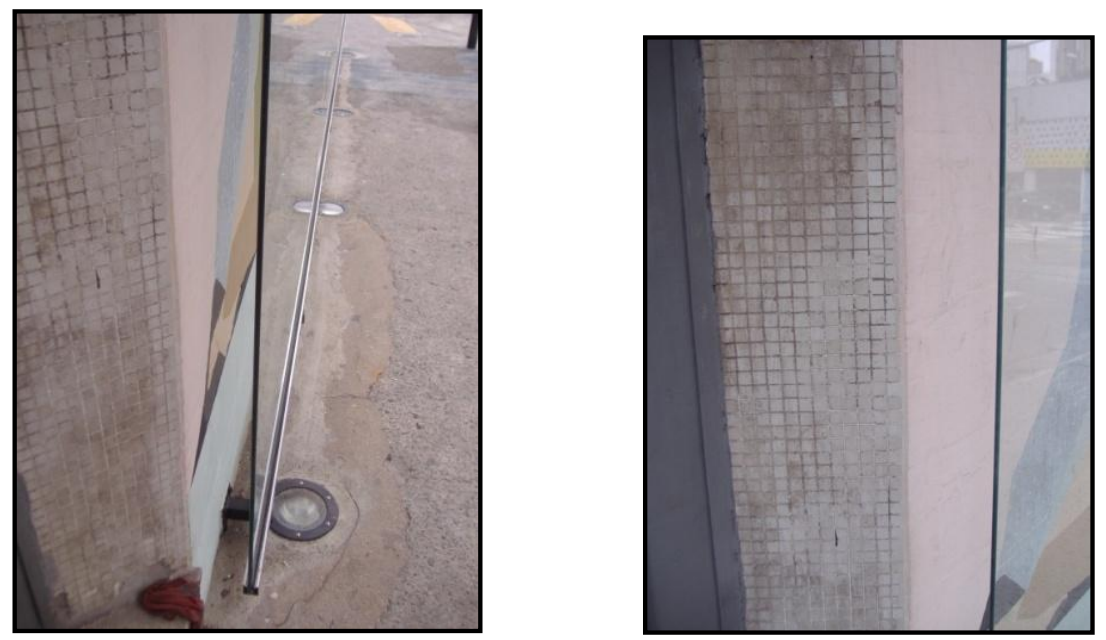

Figura 75 e 76 Detalhes da repintura, iluminação e proteção do mural. Foto: $\quad$ Vera Wilhelm, 2008

Em ambos os casos de intervenções nas obras do artista Clovis Graciano foram realizadas repinturas, sendo que por motivos diferentes e em períodos distintos de tempo.

Podemos considerar alguns aspectos em cada um deles:

- Aplicação de princípios de restauração.

- Uso do espaço (edificação) e inserção da obra mural.

- Uso de material compatível.

- Trabalho conjunto da recuperação da arquitetura e da arte mural.

- Registro da intervenção realizada.

A intervenção da primeira obra foi realizada, em 1978 num período em que no Brasil ainda não haviam se difundido tanto os critérios que norteiam o trabalho de restauração de obras artísticas a nível internacional, critérios fundamentados na Teoria de Restauração de Cesare Brandi de 1963. A restauração ainda era compreendida como uma "renovação" um "embelezamento de uma obra" que tivesse ou não algum tipo de problema ou dano físico.

O uso das duas edificações continuou sendo o mesmo, o que permitiu manter a obra em seu local de origem integrada ao contexto e reconhecida pelos usuários, facilitando assim a sua preservação no espaço da edificação.

O motivo da intervenção na primeira obra não foi esclarecido, mas a execução ocorreu com a autorização do próprio artista. O material usado no 
tratamento $^{95}$ não se restringiu as áreas com danos, mas foi sobreposto a toda superfície da obra o que contraria os princípios formulados por Brandi e reiterados nos princípios do ICOMOS:

\begin{abstract}
A reintegração estética contribui para minimizar a visibilidade dos danos e deve ser executada principalmente com material diferente do original. Os retoques e as reconstruções devem ser executados de modo que sejam distinguíveis do original. Todas as adições devem ser facilmente removíveis. As repinturas devem ser evitadas. ${ }^{96}$ (ICOMOS, 2003, art. 5 tradução nossa).
\end{abstract}

A intervenção na obra do Teatro foi realizada logo após a primeira reforma da edificação em 1976. Este fato pode sugerir que anteriormente houve uma preocupação em dar algum tipo de tratamento ao mural do mesmo modo que ocorreu com a edificação, ou pode sugerir que a intervenção no mural tenha sido feita por causa de algum acidente ocorrido, sem considerar a necessidade de um tratamento conjunto da edificação e da obra mural.

Não foram encontrados registros de um trabalho executado no mural, mas somente o depoimento de um funcionário do museu ao arquiteto autor do relatório sobre a obra onde mencionava que o próprio artista tinha dado a autorização para execução da restauração.

A outra intervenção, na segunda obra de Clovis Graciano, do edifício residencial e comercial, realizada em 2007, também é uma intervenção de repintura, apesar de todos os meios de comunicação já disponibilizarem informações a respeito e de já existir um documento com princípios ${ }^{97}$ cujo conteúdo é diretamente voltado à área de preservação de murais.

Neste caso o uso da edificação também permaneceu o mesmo o que facilitou a preservação da obra mural em seu local. A sua implantação na área externa, alinhada a calçada e integrada ao espaço urbano, segundo princípios de uma arquitetura moderna, facilitou o acesso à obra a sua visualização pelo transeunte,

\footnotetext{
95 Para uma definição mais precisa do tipo de tinta usado é necessário fazer alguns testes laboratoriais ou na existência de um sistema portátil de EDXRF, avaliar in loco e obter algumas informações sobre os componentes da tinta.

96 ICOMOS (2003) "Aesthetic reintegration contributes to minimising the visibility of damage and should primarily be carried out on non-original material. Retouching and reconstructions should be carried out in a way that is discernible from the original. All additions should be easily removable. Over-painting must be avoided" (ICOMOS 2003, ARTICLE 5)

97 Princípios do ICOMOS para a Preservação e Conservação - Restauração das Pinturas Murais (2003). Victoria Falls, Zimbabwe: 2003.
} 
mas atualmente representa um foco atrativo para ações de vandalismo (pichação) bem característica dos tempos atuais. Uma questão que se torna importante e que deve ser considerada segundo cada caso.

O uso de materiais não compatíveis com o tratamento de restauração de uma obra mural feita em pastilhas de cerâmica e tratada com tinta, além do fato da não ter se restringindo somente à área onde se encontrava o dano, levaram a descaracterização do edifício. No artigo cinco dos princípios do ICOMOS sobre tratamento de conservação e restauração temos:

Todas as intervenções, tais como consolidações, limpezas e reintegrações, devem ser limitadas a um nível mínimo necessário para se evitarem quaisquer reduções do material ou da autenticidade pictórica. ${ }^{98}$ (ICOMOS, 2003, art. 05 tradução nossa).

A obra de recuperação do mural não foi planejada em conjunto com a recuperação da edificação e conseqüentemente a execução equivocada de algumas medidas no mural gerou outras ações, também danosas a edificação. Não foram encontrados também registros e documentação de um trabalho executado no mural mesmo que a edificação não receba proteção legal.

As pinturas murais são parte integrante do edifício ou da estrutura. Por essa razão, a sua conservação deve ser considerada em conjunto com a estrutura arquitetônica e de seu entorno. Qualquer intervenção no monumento deve levar em consideração as características específicas das pinturas murais e os termos da sua preservação. ${ }^{99}$ (ICOMOS, 2003, art. 05)

As duas obras estudadas com intervenções feitas em períodos diferentes contrariam os princípios de mínima intervenção, reversibilidade e distingüibilidade.

Entre uma intervenção e outra se passaram trinta anos. Porém, a constatação reflete que ainda existem pessoas atuando empiricamente na área de restauração de murais em edificações de usos diversos comprometendo e descaracterizando as obras.

\footnotetext{
${ }^{98}$ ICOMOS (2003) "All interventions, such as consolidation, cleaning and reintegration, should be kept at a necessary minimal level to avoid any reduction of material and pictorial authenticity"

99 "Wall paintings are an integral part of the building or structure. Therefore, the conservation should be considered together with the fabric of the architectural entity and surroundings. Any intervention in the monument must take into account the specific characteristics of wall paintings and the terms of their preservation".(ICOMOS 2003, article 05)
} 
Todavia, é possível constatar que também houve um aumento significativo de profissionais que passaram a atuar na conservação e restauração de obras murais e que já possuem formação em conservação e restauração, mas nem sempre, todos os princípios sugeridos pelo ICOMOS têm sido seguidos ou aplicados por eles.

Destacamos que os princípios datam de 2003 e são relativamente recentes. Além disso, a documentação existente sobre as obras é escassa e são raros os relatórios de intervenções em murais encontrados nas instituições, quer pelo número pequeno de obras em edificações tombadas, quer pela falta de um planejamento preventivo. Os próprios órgãos de preservação que deveriam executar um trabalho de fiscalização não possuem corpo técnico tão especializado ou não realizam um trabalho preventivo e de orientação neste sentido.

Reconhecemos que, também, se torna mais difícil exigir do profissional que realize o máximo possível da documentação, pois se esbarra em uma série de questões, como a formação do profissional o reconhecimento da profissão, ${ }^{100}$ que devem ser refletidas a fim de que a adequada intervenção venha a ser feita.

A inexistência de uma proteção legal das obras agrava e impede uma fiscalização e acompanhamento das intervenções realizadas.

A realização de um levantamento preventivo, uma documentação e um acompanhamento dos procedimentos executados nas obras é a melhor forma de se garantir a preservação do patrimônio. No caso do patrimônio moderno é imprescindível que esse trabalho seja realizado o quanto antes para que as inúmeras obras que ainda se encontram em sua forma ou constituição original não sejam danificadas pela intervenção realizada de forma inadequada e coloquem em risco nosso patrimônio ou aquele que pode ou poderia vir a ser o nosso patrimônio.

\footnotetext{
${ }^{100}$ Sobre a regulamentação da profissão consultar ABRACOR: <http://www.abracor.com.br/novosite> item reconhecimento da profissão.
} 
PARTE III - NORMALIZAÇÃO DO PROCESSO 


\section{CAPITULO IV - O Profissional de Conservação e Restauração}

\subsection{Formação, Atuação, Reconhecimento da profissão.}

A preocupação com a formação de restauradores para atuação nos bens móveis e integrados sempre foi da esfera federal, a primeira instituição a ser implantada e a sentir a necessidade deste tipo de profissional. Contudo, a necessidade de descentralização das atividades de conservação e restauração e o aparecimento de órgãos de preservação estaduais e municipais acabaram por transferir e/ou compartilhar essas atividades com a esfera federal de preservação e, outros ateliês foram criados, mas somente em algumas regionais eles adquiriram força e atuação significativas.

Na década de 1970 como relata RAMOS FILHO (1987) são criados também os primeiros cursos regulares de restauração em Minas Gerais. Em 1970 o curso da Fundação de Artes de Ouro Preto (FAOP) de nível técnico coordenado por Jair Afonso Inácio e em 1978 é montado um curso de restauração com um ano de duração que se realizou durante dois anos consecutivos até que o órgão, o Centro de Conservação e Restauração de Bens Culturais Móveis (CECOR), vinculado a Escola de Belas Artes da Universidade Federal de Minas Gerais fosse instituído em 1980 com sede própria.

Aos poucos estava se formando o perfil do profissional no Brasil e se definindo as suas atribuições dentro deste complexo trabalho de restauração, que se realizado "in loco", envolvia outros profissionais. Através da formação do conservador/restaurador as práticas até então empíricas vem dando gradativamente lugar a uma formação especializada em MG e comprometida com a área científica.

O CECOR trabalha em parceria com o órgão federal e estadual, atendendo a solicitações de trabalhos de conservação e restauração a serem realizados em obras oriundas de diversas instituições e cidades de Minas Gerais.

A década de 1980 se distinguiu pela consolidação dos trabalhos deste Centro que desde sua criação tem sido a instituição responsável pela pesquisa e formação dos restauradores no país, apesar da existência de disciplinas já relacionadas à conservação e restauração ou cursos de curta duração em outras universidades como a UFRJ, UFBA. 
Durante o período de dez anos a partir de 1989 também foram ministrados cursos de pós-graduação em conservação e restauração com duração de quatro meses, formando seis turmas, no total, oferecidos pela Universidade Federal do Rio de Janeiro (UFRJ).

Foram realizados também os primeiros seminários de profissionais que atuavam em conservação e restauração do patrimônio cultural através da Associação dos Conservadores e Restauradores de Bens Culturais a ABRACOR ${ }^{101}$ fundada em 30 de maio de $1980 \mathrm{com}$ sede na cidade do Rio de Janeiro.

Desde a década de 1980, mais precisamente desde 1986 o IPHAN, em parceria com VITAE, promoveu ações de inventário de bens móveis e integrados através do "Programa de Inventário Nacional de Bens Móveis e Integrados (INBMI)" em todo o Brasil, como uma ação de proteção patrimonial segundo uma metodologia padronizada. Iniciou no Estado de Minas Gerais e estendeu-se pelos estados de Pernambuco, Bahia, Rio de Janeiro, Goiás, etc.

A década de 1990 é marcada pelo aumento da atuação do CECOR em parceria com o IPHAN (federal) e IEPHA (estadual) de Minas Gerais e com instituições estrangeiras, com a valorização de um trabalho científico e interdisciplinar e com a introdução de novos conceitos na área de preservação que tem orientado atualmente as atividades de várias instituições que se ocupam da preservação dos bens culturais em todo o país.

A parceria estabelecida com o Getty Conservation Institute (EUA) e com a VITAE, proporcionou a realização de um programa de expansão da Conservação Preventiva na America Latina. Os resultados deste programa têm sido evidenciados de maneira mais imediata principalmente com relação aos bens móveis em instituições como os museus. A conservação preventiva tem alterado substancialmente a linha de atuação da preservação dos bens móveis e gradativamente dos bens integrados, considerando o gerenciamento ambiental como forma de controle de degradações e reduzindo e/ou evitando a ação de intervenção direta nos bens culturais.

\footnotetext{
${ }^{101}$ A ABRACOR vem realizando bi-anualmente seus seminários desde 1985 em diferentes cidades: dezembro de 1985 no Rio de Janeiro; Agosto/setembro de 1988 em Gramado no Rio Grande do Sul; outubro de 1990 no Rio de Janeiro; outubro de 1992 no Rio de Janeiro; Novembro de 1994 em Petrópolis no Rio de Janeiro; outubro de 1996 em Ouro Preto; de 1998 em Salvador; novembro de 2000 em São Paulo; outubro de 2002 no Rio de Janeiro; de 2004 no Rio de Janeiro; agosto/setembro de 2006 em Fortaleza; abril de 2009 realizado em Porto Alegre no Rio Grande do Sul.
} 
Até o ano de 2006 formaram-se profissionais especialistas no Centro de Conservação e Restauração de Bens Culturais Móveis da Escola de Belas Artes da Universidade Federal de Minas Gerais CECOR/EBA/UFMG ${ }^{102}$, curso que tinha a duração de dois anos e era reconhecido no país e o no exterior. O curso foi interrompido e foi criada a primeira graduação em nível Superior de Conservação e Restauração de Bens Culturais da Escola de Belas Artes da Universidade Federal de Minas Gerais em 2008. A atual estrutura do curso permite uma formação geral básica nos quatro primeiros semestres e do quinto em diante até o oitavo o aluno pode dar a ênfase em uma área específica, que pode ser a da Conservação Preventiva, Conservação-Restauração de Papel, Conservação-Restauração de Pintura e Conservação-Restauração de Escultura. ${ }^{103}$

Apesar de uma formação teórica agora de maior amplitude, englobando disciplinas que até então não eram oferecidas, existe ainda uma lacuna na formação principalmente em relação à arte mural.

Diferentemente do que ocorre aqui entre nós a formação de profissionais nesta área, já é tradição em alguns países europeus como a Itália, a Alemanha, Inglaterra, entre outros.

A primeira escola criada de restauração na Itália foi em 1939 o Istituto Centrale per II Restauro (ICR) atualmente denominado de Istituto Superiore Centrale per II Restauro (ISCR) fundada por Cesare Brandi e Giulio Carlo Argan, que tem atuado também em trabalhos de conservação e restauração de obras de arte mural e em cujo corpo técnico se destacou a atuação do casal Paolo e Laura Mora que ministraram aulas e executaram obras em diversos locais e países, além de Paul Philippot que em conjunto com eles escreveu a obra aqui já descrita Conservation of Wall Paintings em 1984. Além desta existem outras instituições na Itália que também são responsáveis pela formação de profissionais nesta área.

$\mathrm{Na}$ Alemanha várias escolas de formação de conservadores restauradores possuem como área optativa a conservação-restauração de pinturas murais e superfícies arquitetônicas. ${ }^{104}$ Heritage (2010) descreve que a instrução do

\footnotetext{
102 O CECOR iniciou seus trabalhos em 1978 e foi oficialmente instituído em 1980. Ele completou recentemente trinta anos de existência.

${ }^{103}$ A estrutura curricular pode ser vista no site da instituição EBA/UFMG. Disponível em: < http://www.eba.ufmg.br/>. Acesso em: 04 jan. 2011

104 Dentre as escolas se destacam a Fachhochschule Köln; Fachhochschule Potsdam; Fachhochschule Erfurt Fachbereich Konservierung und Restaurierung; Hochschule für Angewandte
} 
profissional na Alemanha demonstra que a base dos programas de formação profissional ainda se encontra direcionada para a pintura mural, mosaicos, douramento e policromia arquitetônica, mas que se encontra em expansão em função das diferentes manifestações que surgem, no século XXI. O autor ainda destaca a crescente introdução da conservação preventiva nos programas acadêmicos.

$\mathrm{Na}$ Inglaterra uma das escolas mais conhecidas na formação de conservadores e restauradores é o Courtauld Institute of Art, que apresenta o curso de mestrado na área de pintura mural. ${ }^{105}$

A tradição na formação de conservadores-restauradores nesta área, que já é de longa data no continente europeu, ainda apresenta um potencial a ser desenvolvido no Brasil.

Na realidade brasileira não temos ainda nenhum curso superior de graduação de conservação e restauração que tenha como área de formação ou opcional de especialização, a área de conservação e restauração de murais.

A maioria dos profissionais que atuam no ramo de conservação de pinturas ou arte mural são provenientes da área artística e da arquitetura e poucos tem uma formação específica na área de murais.

Cursos de curta duração ou de formação de nível Técnico de Conservação e Restauração tem sido realizados e criados em vários locais e estados principalmente de meados da ultima década deste século para cá.

Em 2004 a Escola Técnica da Universidade Federal do Paraná criou um Curso Técnico de Conservação e Restauro com ênfase em pintura mural, com duração de um ano e quatro meses, porém, o curso não teve continuidade. ${ }^{106}$

Em 2008 em São Paulo foi criado um Curso Superior de Tecnologia de Conservação e Restauro em uma universidade particular, na Pontifícia Universidade Católica (PUC) de São Paulo, com disciplinas na área de pintura mural. ${ }^{107}$

\footnotetext{
Wissenschaft und Kunst, Fachbereich Konservierung und Restaurierung, Hildesheim; Hochschule für bildende Künste Dresden Kunsttechnologie, Konservierung und Restaurierung von Kunst und Kulturgut.

${ }^{105}$ Informações sobre o curso MA in Conservation of Wall paintings está Disponível em:

$<$ http://www.courtauld.ac.uk/degreeprogrammes/postgraduate/walls/projects/projects.shtml

106 Informações sobre 0 curso nos Anais da ABRACOR. Disponíveil em: $<$ http://www.abracor.com.br/novosite/congresso/Anais\%20do\%20X\%20Congresso.pdf> e também em:< http://www.restaurabr.org/arc/arc06pdf/06_OrieteCavagnari.pdf>. Acesso em: 20 abr. 2011.

107 PUC Grade curricular do Curso Superior de Tecnologia de Conservação e Restauro. Disponível em:<http://www3.pucsp.br/cursos/42/matriz curricular>. Acesso em: 20 abr. 2011.
} 
Essa lacuna na formação se refletiu diretamente na prática dos profissionais da área em São Paulo, não só daqueles que se ocupam da arte mural, mas também e, principalmente daqueles que trabalham geralmente com pintura mural decorativa/artística.

A lacuna na formação demonstra que a prática das intervenções de conservação-restauração em murais ainda está vinculada às atividades práticas, empíricas sem quaisquer vínculos com a área técnico-científica ou com qualquer juízo crítico como já propunha Cesare Brandi, quando dizia que:

"Mas, qualquer que seja a intervenção, será, outrossim, a única legítima e imperativa em qualquer caso; a única que deve explicar-se com a mais vasta gama de subsídios científicos; [...]" (BRANDI, 2004, p. 31)

Em função disto a maioria dos profissionais da área de restauração de pintura acabou se envolvendo com trabalhos de conservação e restauração de obras murais, o que nem sempre significou uma atuação ou abordagem correta na área em função das especificidades do suporte e da contextualização da obra. Isso só enfatiza a necessidade de um trabalho conjunto e interdisciplinar com arquitetos, engenheiros, químicos, biólogos, etc.

Outro aspecto a ser considerado é que em alguns cursos superiores de arquitetura em SP, tem na ultima década, intensificado ou tornado constante disciplinas voltadas para identificação, análise e metodologia de conservação e restauração e de pinturas murais.

A formação iniciada em vários estados através de disciplinas ou cursos em universidades públicas apresentou no caso de São Paulo uma situação diferenciada, pois a formação restringiu-se a realização de cursos de restauração criados por profissionais e/ou escolas particulares. A inexistência de uma estrutura consolidada de formação na área aqui, se reflete no campo da prática profissional que apresenta diferentes situações.

Esta realidade trouxe consigo algumas implicações que se tornaram evidentes na atuação prática dos profissionais e que foram somente adquirindo perspectivas de mudanças com a difusão do conhecimento daqueles profissionais que realizaram sua formação no exterior e posteriormente passaram a atuar na cidade de São Paulo. 
Contudo, a inserção destes profissionais no nível acadêmico, para o ensino universitário só ocorreu em fins dos anos 1990 e, portanto, a formação de novos profissionais na área de conservação e restauração está passando por mudanças e praticamente se estruturando na cidade.

Hoje existe um número maior de escolas de nível técnico, particulares e públicas e de disciplinas afins nos cursos de graduação, principalmente nos cursos de arquitetura. Porém, como já observado a lacuna na formação de conservadores e restauradores especialistas em murais ainda permanece.

Paralelamente a essa criação de estruturas de ensino, que com certeza agora terão seu número elevado em função do recente reconhecimento da profissão, observa-se os esforços feitos para a criação de um código de ética.

Somente em meados da ultima década em 2005 foi elaborado o código de ética para o exercício da profissão no contexto brasileiro. O código foi realizado com a reunião de profissionais de diferentes estados e associações, como a ABER, APCR, ACCR, ACOR.IT, ACOR RS. O código criado foi baseado no Códigos do International Council of Museums - ICOM, Code of Ethics Copenhagen 1984, e seguiu os mesmos padrões do American Institute of Conservation - AIC, do European Federation of Conservator-Restorers' Organizations - ECCO e do Código de Ética: um enfoque preliminar de Edna May de A. DUVIVIER, do Boletim da Associação Brasileira de Conservadores-Restauradores de Bens Culturais ABRACOR, Ano VIII, N. 1 - Julho/1988. ${ }^{108}$

O código de ética elaborado estabelece os princípios e obrigações para a prática do profissional e as obrigações deste para com os bens culturais incluindo a pesquisa e a documentação, a relação com o proprietário ou responsável legal pela obra, a relação com o público e, a relação do profissional com os colegas de profissão.

As primeiras manifestações no sentido de definir a atuação do profissional de conservação-restauração no contexto internacional apareceram com a criação do Código de Ética do ICOM-CC "The Conservator-Restorer: a Definition of the Profession" foi elaborado em Copenhagem em 1984 que é baseado no texto apresentado por Agnes Ballestrem ao ICCROM em 1978 e que foi discutido pelo

\footnotetext{
${ }^{108} \mathrm{O}$ código de ética criado está disponível em:

$<$ <ttp://www.apcr-sp.com.br/quemsomos/codetica.php $>$. Acesso em: 03 fev.2011.
} 
grupo de trabalho para a formação em conservação e restauração do ICOM-CC em 1978 no Zagreb.

O documento teve uma primeira versão em 1981 na reunião tri-anual do ICOM-CC em 1981 e posteriormente finalizado em 1984. O documento tem por objetivo definir princípios e requisitos da profissão já que em vários países a profissão de conservador-restaurador é ainda indefinida e recebem o nome de conservadores ou restauradores de acordo com a extensão e profundidade de seu treinamento/instrução.

Através do documento definem-se as atividades do profissional diferenciandoas de outras profissões correlatas algumas das quais já são regulamentadas - no contexto europeu - e apresentam suas normas profissionais, como o caso do arquiteto, do engenheiro e do arqueólogo. Destacam-se as atividades a serem desenvolvidas pelo profissional e o impacto que elas podem causar nas obras, bem como o tipo de formação ampla que o profissional deve receber relacionada à área artística, técnica e científica, além de uma experiência prática.

O Documento de Pavia, elaborado em 1997 em uma reunião de profissionais ligados a conservação e restauração e estabeleceu 13 recomendações necessária para garantir a preservação do patrimônio cultural, baseadas no documento já escrito em 1993 pelos órgãos profissionais E.C.C.O ${ }^{109}$ atuantes na União Européia em colaboração com todos os especialistas no campo.

As recomendações incentivam as ações relativas ao reconhecimento e promoção das atividades de conservação e restauração como uma disciplina de nível universitário ou equivalente envolvendo as diferentes categorias de patrimônio e estabelecendo um intercâmbio interdisciplinar entre ciências humanas e ciências naturais, em ensino e pesquisa.

Elas incentivam o desenvolvimento do profissional conservador-restaurador segundo as linhas de atuação profissional estabelecidas pelo ECCO 1993/1994 destacando a sua participação e sua importância em projetos como articulador entre

${ }^{109}$ E.C.C.O.(European Confederation of Conservator-Restorers' Organisations) a Confederação Européia das Organizações de Conservadores e Restauradores representa profissionais associados de 16 países e é responsável pela promoção da profissão de conservador-restaurador no plano prático, científico e cultural. Com objetivo de lutar pelo reconhecimento da profissão e de garantir um nível de instrução elevado a organização criou o guia profissional que contém três partes sendo: informação sobre a profissão, código de ética e requisitos básicos para educação em conservação/restauração. 
profissionais, público e agentes decisores, nas questões relativas a projetos de conservação e restauração.

As recomendações incentivam ainda o desenvolvimento e a definição da profissão e das atribuições do profissional no nível europeu, buscando estabelecer um equilíbrio entre 0 ensino teórico e prático e a cooperação entre ensino/treinamento e as instituições de pesquisa e o desenvolvimento de pesquisa em conservação e restauração e a disseminação de informações dos projetos.

Um dos pontos importantes do documento também é o reconhecimento da necessidade de se estabelecer um quadro regulatório para garantir a qualidade da intervenção no patrimônio cultural ou seu entorno visando evitar a ação e impacto das forças do mercado. O quadro deve conter providências relacionadas à competência de firmas e equipes de profissionais de conservação e restauração bem como providências de uma série de especificações para projetos de conservação e restauração além de um glossário com definições conceituais.

$\mathrm{Na}$ realidade européia o conservador-restaurador não é uma profissão reconhecida apesar dos inúmeros cursos existentes inclusive de graduação. Portanto, existe uma preocupação maior em equiparar a formação dos diferentes cursos como forma de garantir a qualidade da formação do profissional e também como requisito para atender a declaração de Bolonha de 1999 e o Documento de Pavia de 1997.

A elaboração do nosso código de ética em 2005, não extingue, todavia, a atuação de profissionais não qualificados no mercado, pois ele não apresenta a mesma força que uma legislação, mas contribui como conduta moral do profissional.

A profissão de conservador-restaurador por não ser, até então, reconhecida no Brasil ${ }^{110}$ permitia a atuação de uma gama de profissionais bastante diversificada na conservação e restauração de bens culturais. A não regulamentação da profissão e a inexistência de uma fiscalização facilitaram a atuação de diversas pessoas na área, cuja produção não correspondia tanto conceitualmente quanto metodologicamente com o que se definia como conservação e restauração pelas organizações internacionais.

\footnotetext{
${ }^{110}$ Ao iniciar esta pesquisa em 2007 foram acompanhados os esforços realizados por profissionais da área na tentativa de se conseguir um reconhecimento da profissão que em novembro de 2010 teve seu projeto de lei aprovado e passou assim a ser reconhecida.
} 
No final do ano passado mais precisamente dia 17.11.2010 foi aprovado na Câmara dos Deputados pela Comissão de Trabalho, de Administração e Serviço Público o texto que regulamenta a profissão de conservador-restaurador de bens culturais móveis e integrados e foi encaminhado para a aprovação pela Comissão de Constituição e Justiça e Cidadania (CCJC) e para a designação de um relator. Em 01.12.2010 foi publicado no diário da Câmara dos Deputados o parecer da Comissão de Trabalho, de Administração e Serviço Público.

$O$ projeto de lei aprovado ${ }^{111}$ que regulamenta o exercício da profissão de conservador-restaurador é o texto substitutivo do relator, deputado Mauro Nazif (PSB-RO), a dois Projetos de Lei: o $\underline{4042 / 08}$, do Senado, e o $\underline{3053 / 08}$, do deputado Carlos Abicalil (PT-MT), apensados.

A regulamentação do exercício da profissão deve a princípio minimizar a atuação empírica uma vez que se estabelecem requisitos básicos mínimos de formação para a atuação na prática. Apesar dessa conquista por parte dos profissionais não ocorrerá de imediato uma alteração na situação em relação à formação do profissional, mas sim a médio prazo.

Para uma efetiva atuação dentro dos princípios éticos da profissão é preciso que se tenham claros os fundamentos teóricos e metodológicos que irão embasar as medidas práticas do campo da conservação e restauração, o que só é conseguido através de uma sólida formação teórica.

A adoção de medidas que permitam uma uniformização e padronização na linguagem de apresentação dos registros de atividades junto às instituições de preservação, poderia ser de grande valia tendo em vista o grande o número de profissionais com formações diferenciadas que agora poderão atuar na área com o amparo legal.

\footnotetext{
111 Disponível em:<http://www2.camara.gov.br/agencia/noticias/TRABALHO-EPREVIDENCIA/151352-COMISSAO-REGULAMENTA-PROFISSAO-DE-CONSERVADORRESTAURADOR.html>. Acesso em: 22 jan. 2011.
} 


\subsection{Interdisciplinaridade.}

As discussões sobre a importância da ciência na preservação do patrimônio se estabelecem desde o século XVIII já com as descobertas arqueológicas, incluindo as pinturas murais das cidades de Pompéia e Herculano e a busca por um método de conhecimento e aprofundamento sobre aquilo que havia sido encontrado.

O reconhecimento da importância de uma fundamentação científica com apoio das ciências naturais também é destacado nos diversos documentos internacionais desde a carta de Atenas 1931 e outros subseqüentes aqui já mencionados.

Essa aproximação das áreas das ciências naturais e das ciências humanas adquire uma nova dimensão com o aparecimento da moderna conservação, principalmente após a segunda metade do século $X X$, quando novos métodos e equipamentos são desenvolvidos e aplicados à área de preservação do patrimônio removendo o caráter artesanal da atuação prática e conferindo um caráter mais científico, segundo Philippot:

"O segundo componente da moderna conservação tem uma origem mais recente desde seu desenvolvimento depois da Segunda Guerra Mundial. A expansão da importância dos estudos tecnológicos da obra de arte trouxe a prática da conservação e restauração do nível de tradicional trabalho da classe artesanal para aquele de uma ciência exatas." ${ }^{\prime 12}$ (PHILIPPOT, 1996, p. 217, tradução nossa)

Nos últimos cinqüenta anos a situação no sistema de ensino nesta área na Europa tem se modificado. Uma vez reconhecida a conservação-restauração como disciplina acadêmica os cursos devem se estruturar com as disciplinas que compõe a formação do profissional. Os vários cursos criados e outros já existentes tentam adaptar suas estruturas curriculares de forma a atender o Documento de Pavia de 1997 e a declaração de Bolonha de 1999 e buscam equilibrar suas grades curriculares com a teoria e a prática, além de e incentivarem cada vez mais a pesquisa.

\footnotetext{
112 "The second component of modern conservation has a more recent origin, since it only really developed after World War II. The expanding role of technological studies of works of art brought the practice of restoration and conservation from the level of traditional working-class artisanship to that of an exact science."(PHILIPPOT, 1996, p. 217)
} 
Portanto, o contato com outros profissionais de diferentes áreas já existe em trabalhos de conservação-restauração há vários anos, divergindo da nossa realidade em que essa aproximação começou a se estabelecer e se difundir nos últimos quinze a vinte anos.

Através dos estudos de casos citados no trabalho verificou-se que se passaram mais de trinta anos e a prática no mercado de trabalho quase não apresentou evolução, apenas alguns exemplos muito pontuais de parceria com as áreas científicas e que não necessariamente estão ligados a área de mural, mas sim, muitas vezes aplicados a estudos de outros objetos de interesse cultural, geralmente bens móveis como pinturas, esculturas, objetos arqueológicos, etc.

No campo da arte mural duas situações se configuram na nossa realidade, a da pesquisa acadêmica com reflexo em algumas aplicações práticas e, a prática no mercado de trabalho. A primeira embasando a sua atuação prática em estudos e diagnósticos subsidiados por métodos científicos em parcerias com profissionais de diversos campos de atuação, que de certa forma estariam 'acessíveis' para consulta, enquanto a segunda ainda caminha a passos lentos sem muitos exemplos significativos de uma atuação interdisciplinar.

As causas residem na inacessibilidade de tais serviços principalmente no início da prática profissional na área mural nos anos 80 , refletindo uma dificuldade de articulação dos distintos campos, de custos e possivelmente da introdução de um interesse nos profissionais das diversas instituições, o que não se configura como tarefa simples sobretudo para profissionais atuantes fora da área acadêmica.

Hoje, com uma situação já bem diferente e uma vez já abertas as frentes e criadas as oportunidades para o estabelecimento destas parcerias dentro da própria universidade, verifica-se que a situação ainda pouco evoluiu em SP e possivelmente em outros locais, tanto que isso ainda se mantém como tema de discussões em encontros e eventos de profissionais da área de conservação e restauração.

A necessidade do suporte técnico da ciência na preservação do patrimônio cultural foi recentemente debatida em encontro do ICOMOS em 2009, no Seminário sobre Patrimônio e Ciência em Curitiba ${ }^{113}$ e como resultado do Seminário foi elaborada a Declaração de Curitiba.

${ }^{113}$ O ICOMOS Brasil realizou nos dias 26 e 27 de março o Seminário Patrimônio e Ciência, que reuniu profissionais ligados à área de restauração para discutir novas tecnologias e ações de proteção aos bens e áreas culturais. O Seminário foi concluído com um texto final de recomendações. 
No documento "Destaca-se que a pesquisa científica da conservação, pelas suas características interdisciplinares, leva a um inter-relacionamento enriquecedor entre os diversos laboratórios e especialistas das universidades, estabelecendo aquele elo perdido que existia nas universidades no passado." (ICOMOS, Curitiba, 2009) e que, portanto, devem ser criados mecanismos que a incentivem, com o apoio oficial e das esferas de decisão.

Dentre vários itens registrados está aquele que menciona que "A natureza específica do patrimônio construído e suas diversidades requer abordagem científica interdisciplinar para resolver e lidar com os riscos e os processos de degradação aos quais os bens estão inevitavelmente sujeitos e ameaçados." (ICOMOS, Curitiba, 2009), incentivando e ressaltando, portanto, a importância deste trabalho conjunto, interdisciplinar na área de preservação.

Para se estabelecer um quadro mais real da situação optou-se por fazer um levantamento de fontes literárias sobre os trabalhos executados e as eventuais parcerias estabelecidas na área de preservação de murais, complementando assim as outras informações obtidas em fontes diversas.

Um passo significativo na área de murais pode ter sido dado por ocasião da realização do workshop sobre Novos Avanços nas Técnicas de Conservação e Restauração de Pinturas Murais realizado em São Paulo em 2000, patrocinado pela VITAE e pelo British Council e ministrado por Sharon Cather, professora do curso de MA em Pinturas Murais do Courtauld Institute of Art, que reuniu profissionais de várias partes do Brasil.

Certamente o evento contribuiu para a difusão de novas questões para reflexão sobre a atuação dos profissionais na preservação da arte mural na nossa realidade, enfatizando principalmente os aspectos relacionados à pesquisa com apoio científico, a documentação de bens integrados, ao monitoramento e a conservação preventiva. $O$ workshop pode ter também colaborado, ou mesmo incentivado a criação do Curso Técnico em Conservação e Restauração com ênfase em Pintura Mural pela Escola Técnica da Universidade Federal do Paraná em 2004, hoje não mais existente.

Além deste evento em 2000, outros foram realizados durante essa década e possibilitaram a divulgação de trabalhos executados na área de murais. 
A participação cada vez mais crescente de profissionais das áreas de ciências naturais (física e química) principalmente desde meados dos anos 1990 e mais intensamente nesta ultima década tem colaborado para a expansão do campo de estudos e pesquisas e conseqüentemente de uma crescente e/ou nova consciência dos profissionais e interessados na área. Isso permitiu a ampliação da possibilidade de realização de trabalhos mais aprofundados, concretizando gradativamente nos trabalhos de conservação e restauração a colaboração interdisciplinar.

Sabe-se que, apesar do crescimento destes trabalhos eles ainda não atingiram por completo a prática do mercado de trabalho, somente com casos muito pontuais da iniciativa privada, restringindo-se a maioria dos estudos ao meio acadêmico.

O quadro abaixo demonstra que desde 1996 têm sido freqüentes os encontros para divulgação de trabalhos na área de preservação desenvolvidos em associação com as ciências naturais. Os eventos ocorreram na cidade são geralmente vinculados a departamentos dentro da Universidade de São Paulo, USP.

Dentre os eventos organizados na área podemos mencionar:

\begin{tabular}{|c|c|}
\hline DATA & EVENTOS EM SÃO PAULO \\
\hline 1996 & $\begin{array}{l}\text { SIMPÓSIO INTERNACIONAL “ANÁLISES FíSICAS E QUÍMICAS NO } \\
\text { ESTUDO DE MATERIAL ARQUEOLÓGICO" } \\
\text { Universidade de São Paulo, São Paulo, SP. Outubro, 1996. Trabalhos } \\
\text { completos publicados na Revista do Museu de Arqueologia e Etnologia da } \\
\text { USP, Suplemento 2, 1997. }\end{array}$ \\
\hline 1996 & $\begin{array}{l}\text { CURSO:"MÉTODOS DE ANALISES CIENTÍFICAS PARA } \\
\text { CONSERVACCÃO E RESTAURO - Prof. Marco Ferreti (ENEA IN } \\
\text { ART/ROMA) Organização:Comissão de Patrimônio Cultural (CPC) da USP e } \\
\text { Centro Universitário Maria Antonia/USP (CEUMA-USP), São Paulo, SP. }\end{array}$ \\
\hline 1998 & $\begin{array}{l}\text { WORKSHOP “DESIGN E USO DE ESPECTRÔMETRO DE ENERGIA } \\
\text { DISPERSIVA (FLUORESCÊNCIA POR RAIOS X) PARA ANALISE DE } \\
\text { MATERIAIS ARTÍSTICOS } \\
\text { Museu Paulista da Universidade de São Paulo, São Paulo,SP - Maio de 1998, } \\
\text { IPT, São Paulo. }\end{array}$ \\
\hline 2002 & $\begin{array}{l}\text { SEMINÁRIO ESPECIAL DO LABORATÓRIO DO ACELERADOR } \\
\text { LINEAR "ARTE \& CIÊNCIA" } \\
\text { Marcia Rizzo (MRizzo Laboratório de Conservação e Restauração de Bens } \\
\text { Culturais) e Prof. Dr. Nemitala Added (IF/USP),Auditório Sul do IF/USP. } 19 \text { de } \\
\text { Dezembro de 2002. }\end{array}$ \\
\hline 2003 & $\begin{array}{l}\text { SIMPÓSIO "MÉTODOS NÃO DESTRUTIVOS DE ANÁLISE E } \\
\text { PATRIMÔNIO HISTÓRICO-CULTURAL: CONSTRUINDO UMA } \\
\text { INTERFASE" - } 28 \text { de maio de } 2003 \text { Instituto de Química da USP, São Paulo, } \\
\text { SP. Disponível em:<http://www.dlafaria.hpg.ig.com.br/simposio.htm> }\end{array}$ \\
\hline
\end{tabular}




\begin{tabular}{|l|l|l|}
\hline 2005 & WORKSHOP SOBRE MÉTODOS ATÔMICO-NUCLEARES PARA \\
& ANÁLISE NÃO DESTRUTIVA EM ARTE, ARQUEOLOGIA E \\
& CONSERVAÇÃO - Instituto de Física da USP, Auditório Abrahão de Moraes, \\
& $\begin{array}{l}\text { São Paulo, SP 06 de junho de 2005. Disponível em: } \\
\text { <http://www.dfn.if.usp.br/pesq/faa/workshop/fisicarte.html> }\end{array}$ \\
\hline 2007 & $\begin{array}{l}10 \text { SIMPÓSIO LATINOAMERICANO DE MÉTODOS FÍSICOS E E } \\
\text { QUÍMICOS EM ARQUEOLOGIA, ARTE E CONSERVAÇÃO DE } \\
\text { PATRIMÔNIO CULTURAL- LASMAC } \\
\text { MASP - Museu de arte de São Paulo - 11 a 16 de junho de } 2007 \text { - São Paulo, } \\
\text { SP. Disponível em: } \\
\text { <http://www.sbf1.sbfisica.org.br/EVENTOS/EXTRAS/LASMAC/geral arte.htm> }\end{array}$ \\
\hline
\end{tabular}

Tabela 1 - Eventos realizados em São Paulo.

Fonte: Tabela organizada com dados fornecidos pelo Prof. Appolini. ${ }^{114}$

Alguns eventos que foram realizados fora de SP tem se repetido a cada dois anos e alternado o local da sua realização, permitindo, assim, que profissionais de outras regiões, como o norte e nordeste tenham maior acesso, além do fato de se realizarem em locais onde já existe um grupo de profissionais engajados em pesquisa e estudos na área.

\begin{tabular}{|c|c|}
\hline DATA & EVENTOS FORA DE SÃO PAULO \\
\hline 2002 & $\begin{array}{l}\text { I SIMPÓSIO DE TÉCNICAS AVANÇADAS EM CONSERVAÇÃO DE } \\
\text { BENS CULTURAIS } \\
\text { Convento de São Francisco, Olinda, Pernambuco } \\
8 \text { a } 12 \text { de dezembro de } 2002 \\
\text { <http://www.physics.ncsu.edu:8380/courses/py299sa/olinda/index } 1 . \text { html> }\end{array}$ \\
\hline 2004 & $\begin{array}{l}\text { II SIMPÓSIO DE TÉCNICAS AVANÇADAS EM CONSERVAÇÃO DE } \\
\text { BENS CULTURAIS - CITECOR } \\
\text { Dentro da programação do I FORUM BRASILEIRO DO PATRIMÔNIO } \\
\text { CULTURAL,Belo Horizonte, Minas Gerais, } \\
1 \text { a } 3 \text { de dezembro de } 2004 \\
\text { <http://www.patrimoniocultural.org/default.asp> }\end{array}$ \\
\hline 2006 & $\begin{array}{l}\text { III SIMPÓSIO DE TÉCNICAS AVANÇADAS EM CONSERVAÇÃO DE } \\
\text { BENS CULTURAIS } \\
\text { Academia Santa Gertrudes, Olinda, PE } \\
14 \text { a } 18 \text { de março de } 2006 \\
\text { < http://www.patrimoniocultural.org/> }\end{array}$ \\
\hline 2009 & $\begin{array}{l}\text { CAPADAC } \\
\text { Caracterização e Datação de Materiais do Patrimonio Cultural (CADAPAC) } \\
\text { Escola Temática Interdisciplinar } \\
\text { São João del Rei (MG) } \\
5 \text { - } 31 \text { outubro } 2009 \\
\text { http://www.cbpf.br/ cadapac/pro_p.htm }\end{array}$ \\
\hline
\end{tabular}

Tabela 2 Eventos realizados fora de São Paulo.

Fonte: Tabela organizada com dados fornecidos pelo Prof. Appolini. ${ }^{115}$

${ }^{114}$ Disponível em:

<http://www.sbf1.sbfisica.org.br/EVENTOS/EXTRAS/LASMAC/Reuni\%F5es\%20Arqueometria\%20\&\% 20afins\%20Brasil.pdf>. Acesso em: 10 out. 2009. 
Paralelamente a estes encontros, várias palestras têm sido realizadas, embora acima não mencionadas, mas que tem colaborado para a ampliação da visão dos profissionais da área com relação às novas possibilidades tecnológicas e de pesquisa em preservação e conservação e restauração como ocorreu com o ciclo "Reuniões Técnicas: Ciências aplicadas e a conservação de bens culturais" realizado pelo CPC-USP, em 2007, com objetivo de aprofundar discussões sobre necessidades do mercado e as oportunidades de colaboração com a universidade.

Outra fonte referência de trabalhos de conservação e restauração de arte mural no Brasil tem sido as revistas eletrônicas, que recentemente são a maneira mais rápida e simples de divulgação dos trabalhos e de acesso ao conhecimento daquilo que vem sendo realizado na área. As revistas são geralmente voltadas à área de patrimônio, arquitetura, ou historia da arte e estão vinculadas a departamentos dentro das universidades ou a organizações não governamentais que se dedicam a preservação.

A revista do Centro de Preservação Cultural (CPC), publicada semestralmente (maio-out/nov-abr.) vem sendo disponibilizada para consulta on line desde sua primeira edição em novembro 2005 e está atualmente em seu $11^{\circ}$ exemplar. ${ }^{116}$

\begin{tabular}{|c|c|c|}
\hline DATA & CPC/ USP & PUBLICAÇÃO \\
\hline $\begin{array}{l}\text { NOV. 2005/ } \\
\text { ABRIL 2006 }\end{array}$ & $\begin{array}{l}\text { Volume } 1 \text { № } 1 \\
\text { NOV. 2005/ABRIL } 2006\end{array}$ & $\begin{array}{l}\text { Fulvio Pennacchi's fresco at the chapel of } \\
\text { the Hospital das Clínicas da FMUSP: } \\
\text { scientific studies for the characterization of } \\
\text { materials and execution }\end{array}$ \\
\hline $\begin{array}{l}\text { NOV. 2006/ } \\
\text { ABRIL 2007 }\end{array}$ & $\begin{array}{l}\text { Volume } 3 \\
\text { NOV. 2006/ABRIL } 2007\end{array}$ & $\begin{array}{l}\text { A arqueologia da arquitetura: um modo de } \\
\text { entender e conservar edifícios históricos - } \\
\text { Regina Tirello }\end{array}$ \\
\hline $\begin{array}{l}\text { MAIO. } \\
2008 / \\
\text { OUTU } \\
\text { BRO } 2008\end{array}$ & $\begin{array}{l}\text { volume } 6 \\
\text { MAIO 2008/OUT. } 2008\end{array}$ & $\begin{array}{l}\text { O CPC-USP e o ciclo "Reuniões Técnicas: } \\
\text { Ciências aplicadas e a conservação de } \\
\text { bens culturais". Regina A Tirello, Maria } \\
\text { Lucia Bressan Pinheiro }\end{array}$ \\
\hline & & $\begin{array}{l}\text { Análises não-destrutivas em de obras de } \\
\text { arte com técnicas atômico-nucleares } \\
\text { Márcia A. Rizzutto }\end{array}$ \\
\hline
\end{tabular}

\footnotetext{
${ }^{115}$ Disponível em:

$<$ http://www.sbf1.sbfisica.org.br/EVENTOS/EXTRAS/LASMAC/Reuni\%F5es\%20Arqueometria\%20\&\% 20afins\%20Brasil.pdf >. Acesso em: 10 out. 2009.

${ }^{116}$ Ela apresenta trabalhos relacionados ao patrimônio cultural, coleções e acervos, conservação e restauração além de resenhas, depoimentos e notícias.

REVISTA CPC, Disponível em:<http://www.usp.br/cpc/v1/php/wf07 revista capa.php?id revista=2>
} 


\begin{tabular}{|l|l|l|}
\hline & & $\begin{array}{l}\text { Métodos e técnicas de caracterização } \\
\text { aplicadas ao estudo do patrimônio cultural: } \\
\text { trabalhos desenvolvidos pelo LFNA-DFIS } \\
\text { Carlos Roberto Appoloni, Paulo S. Parreira, } \\
\text { Fabio Lopes. }\end{array}$ \\
\hline NOV 2008 / & $\begin{array}{l}\text { Volume 7 } \\
\text { ABRIL 2009 }\end{array}$ & $\begin{array}{l}\text { NOV 2008) / ABRIL 2009ização de bens culturais por } \\
\text { espectroscopia de fluorescência de raios X } \\
\text { Augusto Câmara Neiva, Jérémie Dron }\end{array}$ \\
\hline & $\begin{array}{l}\text { Princípios e aplicações de espectroscopia } \\
\text { de fluorescência de Raios X (FRX) com } \\
\text { instrumentação portátil para estudo de bens } \\
\text { culturais } \\
\text { Marco Ferretti. }\end{array}$ \\
\hline
\end{tabular}

Tabela 3- Artigos em revista do CPS USP em São Paulo.

Fonte: $<$ http://www.usp.br/cpc/v1/php/wf07 revista interna.php?tipo=9>. Acesso em: 10 out. 2009.

A literatura técnica especializada aborda geralmente estudos, pesquisas de técnicas e procedimentos e exemplos de casos de trabalhos de restauração de obras murais, porém, representam um número relativamente pequeno dentro da quantidade de obras existentes. Se por um lado essa quantidade reduzida de material pode indicar que nem sempre a obra sofreu intervenções, por outro lado pode indicar também a não realização do registro das intervenções, a dispersão deste tipo de material, ou mesmo a perda de informações ou do conhecimento sobre a obra.

Os trabalhos são geralmente publicados em número ainda reduzido nos ANAIS do Congresso da ABRACOR, ${ }^{117}$ que atualmente está na sua XI edição. ${ }^{118} \mathrm{~A}$ ABRACOR criada em 1980, portanto há trinta anos é a associação responsável pela promoção e divulgação de encontros entre profissionais nacionais da área desde 1986 e também de intercâmbio com outros profissionais atuantes no exterior. Os trabalhos publicados abrangem diferentes áreas de atuação, que com o passar dos anos tem se ampliado e, são geralmente descritivos de pesquisas, estudos e procedimentos, executados por restauradores e arquitetos em obras do nosso patrimônio ou em obras de interesse cultural.

\footnotetext{
117 Os Anais da Associação Brasileira de Conservadores e Restauradores de Bens Culturais de 1985 a 2002 se encontram digitalizados e disponíveis no site da Associação: <http://www.abracor.com.br>. O ultimo encontro o XI Congresso da ABRACOR ocorreu em junho de 2009, na cidade de Porto Alegre.

${ }_{118}$ Até 1994 na sua VII reunião bianual o encontro era denominado Seminário Nacional da ABRACOR alterando-se a partir de 1996 para Congresso da ABRACOR.
} 
$\mathrm{Na}$ área de mural, a grande maioria dos trabalhos são sobre pinturas murais decorativas e artísticas executadas em edificações de uso público e privado, igrejas, fazendas e antigas residências, apresentados dentro de seções nos Anais, seções que vem crescendo em número e categorias de patrimônio ao longo dos anos. Não existe uma regularidade e nem uma seqüência crescente de trabalhos de murais publicados nestes anais, por isso, a quantidade não é exatamente indicativa do número de trabalhos executados.

Fazendo um levantamento das publicações dos ANAIS desde 1988, temos a seguinte situação de trabalhos realizados na área de murais num período compreendido de vinte e dois anos:

\begin{tabular}{|c|c|c|}
\hline DATA & ABRACOR & PUBLICAÇÃO \\
\hline 1988 & $\begin{array}{l}\text { ANAIS DO IV SEMINÁRIO } \\
\text { ABRACOR - } 30 \text { agosto a } 2 \\
\text { setembro de } 1992 \text { - Gramado, } \\
\text { RS. }\end{array}$ & \\
\hline 1990 & $\begin{array}{l}\text { ANAIS DO V SEMINÁRIO } \\
\text { ABRACOR - outubro de } 1990 \\
\text { - Rio de Janeiro,RJ. }\end{array}$ & $\begin{array}{l}\text { "Combate de Fungos em Pintura Mural - } \\
\text { Painel do Hotel da Bahia". José Dirson Argôlo } \\
\text { - Studio Argôlo-Ant. Rest. Ltda., Escola de } \\
\text { Belas Artes/UFBa. }\end{array}$ \\
\hline 1992 & $\begin{array}{l}\text { ANAIS DO VI SEMINÁRIO } \\
\text { ABRACOR - } 5 \text { a } 7 \text { de outubro } \\
\text { de } 1992 \text { - Rio de Janeiro, RJ. }\end{array}$ & $\begin{array}{l}\text { Pintura Mural: fixação e consolidação de } \\
\text { camada pictórica e susbstratos; eliminação de } \\
\text { microorganismos }- \text { Deolinda Conceição } \\
\text { Taveira Moreira - MAG- Museu de Arte de } \\
\text { Goiânia }\end{array}$ \\
\hline \multirow[t]{2}{*}{1994} & 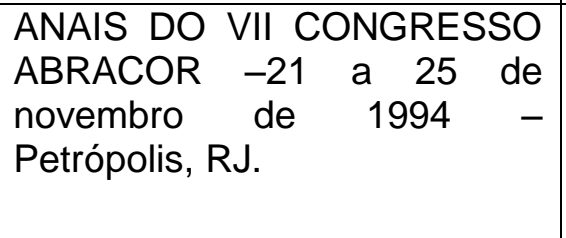 & $\begin{array}{l}\text { Investigacion, diagnóstico y propuesta de } \\
\text { conservación de las Pinturas de David Alfaro } \\
\text { Siqueiros, Ubicadas em la Biblioteca de La } \\
\text { Escuela de México de Chillan - Lilia Maturana } \\
\text { Meza e Monica Bahamondez P. }\end{array}$ \\
\hline & & $\begin{array}{l}\text { Conservação Preventiva para os Murais do } \\
\text { edifício da Administração do canal do Panamá } \\
\text { - Anton Rajer e Gregory Gillbert }\end{array}$ \\
\hline \multirow[t]{2}{*}{1996} & $\begin{array}{l}\text { ANAIS DO VIII CONGRESSO } \\
\text { ABRACOR - } 3 \text { a } 8 \text { de } \\
\text { novembro de } 1996 \text { - Ouro } \\
\text { Preto- MG }\end{array}$ & $\begin{array}{l}\text { Restauro de Pintura Mural no Brasil: tradição } \\
\text { situações e perspectivas - MORAES, Julio } \\
\text { Eduardo Correa Dias de. }\end{array}$ \\
\hline & & $\begin{array}{l}\text { Projeto para a restauração dos painéis do } \\
\text { palácio Pedro Ernesto, Câmara Municipal do } \\
\text { Rio de Janeiro - MENDES, Marylka e } \\
\text { OLIVEIRA, Denise. }\end{array}$ \\
\hline
\end{tabular}




\begin{tabular}{|c|c|c|}
\hline & & $\begin{array}{l}\text { Restauro dos painéis da escola Edmundo } \\
\text { Bittencourt - RIBEIRO, Nelson Porto } \\
\text { (arquiteto); HORVAT, Patricia (historiadora da } \\
\text { arte); PEREIRA, Myriam (restauradora) }\end{array}$ \\
\hline \multirow[t]{2}{*}{1998} & $\begin{array}{l}\text { ANAIS DO IX CONGRESSO } \\
\text { ABRACOR }-25 \text { a } 30 \text { de } \\
\text { outubro de } 1998 \text {, Salvador- BA }\end{array}$ & $\begin{array}{l}\text { Projeto de restauração do Palácio Cruz e } \\
\text { Souza }\end{array}$ \\
\hline & & $\begin{array}{l}\text { O Convento de Nossa Senhora da Visitação } \\
\text { de Vila Verde dos Francos - A conservação e } \\
\text { o restauro da pintura mural do Convento de } \\
\text { Nossa Senhora da Visitação de Vila Verde dos } \\
\text { Francos - } \quad \text { Estremadura - PT } \\
\text { ALBUQUERQUE, Maria João Nunes de. }\end{array}$ \\
\hline 2000 & $\begin{array}{l}\text { ANAIS DO X CONGRESSO } \\
\text { ABRACOR }-6 \text { a } 10 \text { de } \\
\text { novembro de } 2000-\text { São } \\
\text { Paulo, SP. }\end{array}$ & \\
\hline 2002 & $\begin{array}{l}\text { ANAIS DO XI CONGRESSO } \\
\text { ABRACOR - } 20 \text { a } 22 \text { de } \\
\text { setembro de } 2002-\text { Rio de } \\
\text { Janeiro, RJ. }\end{array}$ & \\
\hline \multirow[t]{4}{*}{2004} & $\begin{array}{l}\text { ANAIS DO XII CONGRESSO } \\
\text { ABRACOR - } 28 \text { de agosto a } \\
1^{\circ} \text { de setembro - Fortaleza, } \\
\text { CE. }\end{array}$ & $\begin{array}{l}\text { Transposição do Mural do Artista Jenner } \\
\text { Augusto do Antigo Hotel Pálace para o Teatro } \\
\text { Ateneu Em Sergipe - Ana Maria Villar Leite } \\
\text { Augusto - Universaidade Católica de Salvador } \\
\text { - BA }\end{array}$ \\
\hline & & $\begin{array}{l}\text { Intervenção em Mural de autoria de Cícero } \\
\text { Dias - Simone Arruda - Recife- PE }\end{array}$ \\
\hline & & $\begin{array}{l}\text { Gracias a un Fresco - Lilia Maturana, Mónica } \\
\text { Bahamondez } \\
\text { Centro Nacional de Conservación y } \\
\text { Restauración - Santiago- Chile }\end{array}$ \\
\hline & & $\begin{array}{l}\text { Estudos de caracterização Material e } \\
\text { Executiva dos Afrescos de Fulvio Pennacchi - } \\
\text { Regina A. Tirello e Eliane A. Del Lama - } \\
\text { Unicamp - São Paulo }\end{array}$ \\
\hline \multirow[t]{3}{*}{2009} & $\begin{array}{l}\text { ANAIS DO XIII CONGRESSO } \\
\text { ABRACOR - } 13 \text { a } 17 \text { de abril } \\
\text { de } 2009 \text { - Porto Alegre - RG }\end{array}$ & $\begin{array}{l}\text { Autenticidade e arquitetura: as repinturas e as } \\
\text { restaurações recentes da casa nำ da rua } \\
\text { Robero Simonsen, São Paulo.- Regina Tirello }\end{array}$ \\
\hline & & $\begin{array}{l}\text { Restauração das pinturas murais do hall de } \\
\text { acesso do "palacinho" Gabinete da Vice- } \\
\text { Governadora do Estado do Rio Grande do Sul } \\
\text { - Andrea Lacerda Bachettini e Naida Maria } \\
\text { Vieira Correa. }\end{array}$ \\
\hline & & $\begin{array}{l}\text { Proteção de pinturas murais em edificações } \\
\text { históricas: o caso da estação Guanabara } \\
\text { (Campinas- SP) - Eliana Ribeiro Ambrósio e } \\
\text { Marcos Tognon. }\end{array}$ \\
\hline
\end{tabular}

Tabela 4- Artigos em Anais da ABRACOR.

Fonte:<http://www.abracor.com.br>. Acesso em: 10 out. 2009. 
Existe um número relativamente pequeno de trabalhos apresentados sobre murais nos anos de 80 e 90, aumentando em número somente a partir de 2004.

Outra revista de divulgação é a ARC - Revista Brasileira de Arqueometria, Restauração e Conservação publicada em 2006 com os trabalhos do III Simpósio de Técnicas Avançadas em Conservação de Bens Culturais ${ }^{119}$ - Olinda 2006 que está no seu volume $1 n^{\circ} 6$. Apresenta trabalhos relacionados à aplicabilidade técnica das ciências na preservação de arte mural.

\begin{tabular}{|c|c|c|}
\hline DATA & ARC & PUBLICAÇÃO \\
\hline \multirow[t]{6}{*}{2006} & Volume 1 Número 1 & $\begin{array}{l}\text { Resgate de pintura mural de grande } \\
\text { dimensão da Catedral do Divino Espírito } \\
\text { Santo, Município de Ipameri - Goiás } \\
\text { Alba Tânia Rosaura Macedo; Yahweh A. de } \\
\text { Oliveira e Parreira. } \\
\text { Núcleo de Preservação do Patrimônio } \\
\text { Cultural da Agência Goiana de Cultura - } \\
\text { Pedro Ludovico Teixeira (agepel) }\end{array}$ \\
\hline & & $\begin{array}{l}\text { Restauração dos Painéis em Azulejos } \\
\text { Modernistas da Fundação Oswaldo Cruz. } \\
\text { Bettina Collaro Goerlich De Lourenço; } \\
\text { Estefânia Neiva Mello. } \\
\text { Fundação Oswaldo Cruz, Casa De Oswaldo } \\
\text { Cruz - Departamento De Patrimônio } \\
\text { Histórico. }\end{array}$ \\
\hline & & $\begin{array}{l}\text { Restauração das Pinturas Murais em cal no } \\
\text { Sítio do Capão - Jardim Anália Franco São } \\
\text { Paulo/Sp } \\
\text { Caroline Tonacci Costa }\left(^{*}\right) \text {; Laura Rita Facioli } \\
\left(^{\star}\right) \text {; Ana Clara Giannecchini }\left({ }^{*}\right) \text {; Elaine } \\
\text { Bottion; }\left(^{*}\right) \text { Croma Arquitetura e Restauro S/S } \\
\text { LTDA }\end{array}$ \\
\hline & & $\begin{array}{l}\left.\left(^{*}\right) ; \text { Regina A. Tirello }\left(^{* *}\right) ;{ }^{*}\right) \text { Instituto de } \\
\text { Geociências da Universidade de São Paulo } \\
\text { IGc-USP; }\left(^{* *} \text { Centro de Preservação Cultural }\right. \\
\text { da Universidade de São Paulo CPC-USP e } \\
\text { Faculdade de Engenharia Civil, Arquitetura e } \\
\text { Urbanismo da Universidade Estadual de } \\
\text { Campinas FEC-UNICAMP }\end{array}$ \\
\hline & & $\begin{array}{l}\text { Mural “Os Bandeirantes” De Candido } \\
\text { Portinari Obra De Transposição E } \\
\text { Restauro.Arq. Eliane Pavan Tassi }\left(^{\star}\right) \text {; Arq. } \\
\text { Arnaldo Domingos Sarasá Martin }\left(^{\star}\right)\left(\left(^{\star}\right) \text { Atelier }\right. \\
\text { Artístico Sarasá }\end{array}$ \\
\hline & & $\begin{array}{l}\text { Aplicação de um equipamento Portátil de } \\
\text { EDXRF no acompanhamento dos trabalhos } \\
\text { de restauro de pinturas murais na Igreja da }\end{array}$ \\
\hline
\end{tabular}

${ }^{119}$ Revista ARC disponível em:<http://www.restaurabr.org/arc/>. Acesso em: 10 nov.2009. 


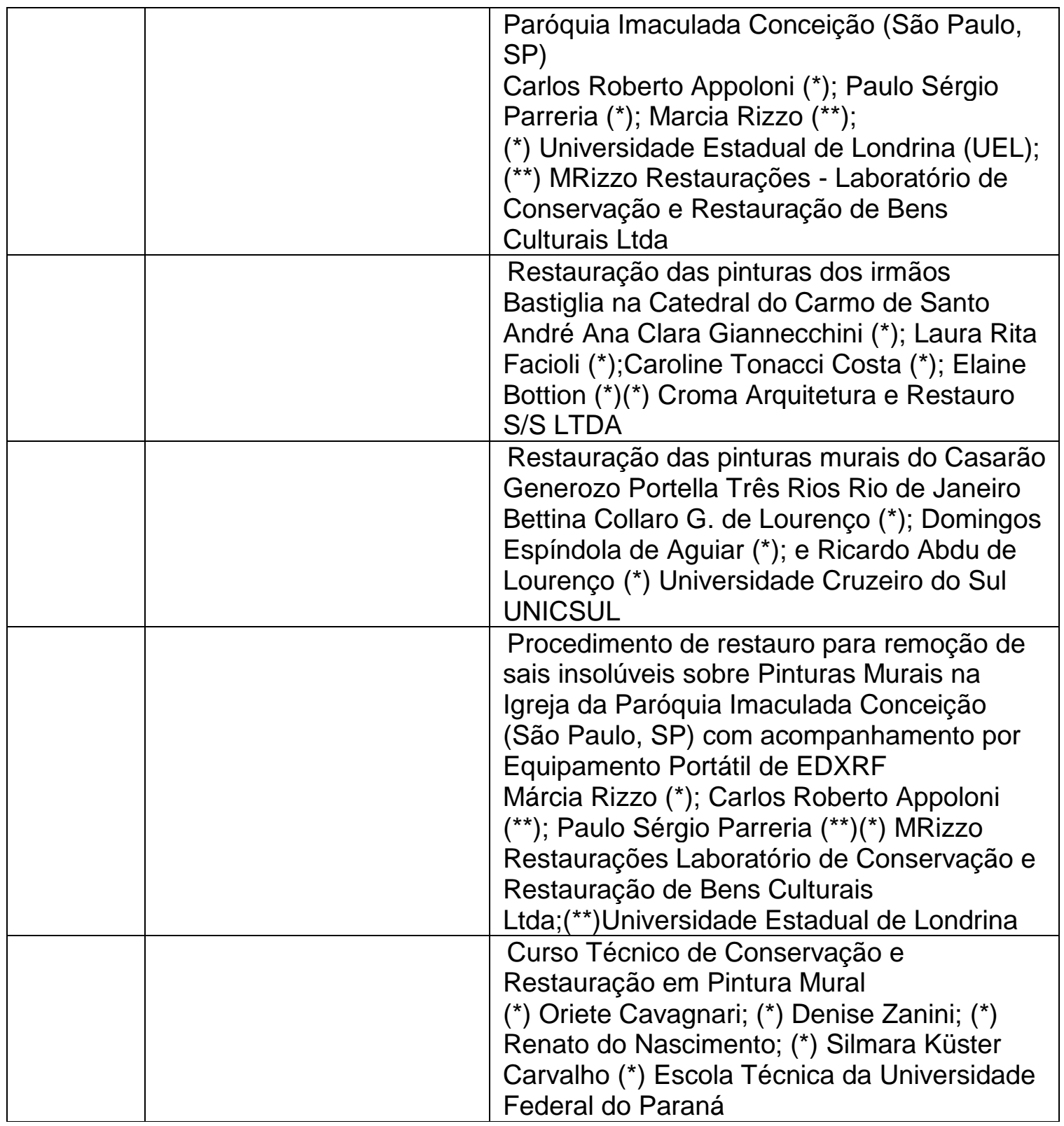

Tabela 5- Artigos sobre murais na Revisa ARC.

Fonte: <http://www.restaurabr.org/arc/>. Acesso em: 10 out. 2009.

Além das revistas já citadas outras revistas eletrônicas em São Paulo também contribuem para a ampliação e divulgação do conhecimento destes trabalhos sobre murais e sobre as ciências aplicadas a preservação de bens culturais dentre elas as revistas de pós-graduação das faculdades de arquitetura da FAU/USP, da pósgraduação de São Carlos, da pós-graduação Mackenzie, as Revistas dos Institutos de Artes e de Faculdades de Artes, a revista do Fórum Patrimônio, ${ }^{120}$ entre outras.

${ }^{120}$ A revista apresenta artigos sobre Ambiente Construído e Patrimônio Sustentável, com publicações de contribuições técnicas e científicas relacionadas ao patrimônio cultural e natural. Disponível em: $<$ http://www.forumpatrimonio.com.br/>. 
Ainda na bibliografia existe um número crescente de trabalhos acadêmicos de pesquisa que vem sendo realizados junto às universidades e revelam o interesse cada vez maior dos estudantes e profissionais pela área de arte mural nestes últimos anos, mais precisamente, na ultima década.

Apesar das várias relações aqui apresentadas de trabalhos acadêmicos, ou não, pode-se dizer que, o que foi exposto só confirma a situação já relatada aqui neste trabalho sobre o aperfeiçoamento profissional ter se intensificado nos últimos anos e a gradativa implantação das ciências naturais nos trabalhos de pesquisa em preservação a nível acadêmico e, ainda, o tímido reflexo desta atividade conjunta no campo da prática da preservação, como recurso de embasamento científico para diagnósticos, conhecimentos sobre técnicas e materiais dos murais e processos de degradação.

Diferentemente do que ocorre a nível nacional a bibliografia técnica especializada no exterior é significativamente maior, tanto na área de historia da arte, com inúmeras produções bibliográficas sobre a arte mural, sua história, evolução técnica, como também na área da conservação, com publicações de trabalhos técnicos de conservação e restauração desenvolvidos por instituições de preservação e empresas, em diferentes países, além da produção acadêmica nas universidades incluindo também as publicações produzidas pelos inúmeros encontros de profissionais da área ${ }^{121}$.

Embora, a produção seja maior que a nossa é possível se dizer que, em relação às outras áreas como pintura de cavalete, escultura, arqueologia e arquitetura a produção bibliográfica sobre a arte mural ainda representa uma pequena parcela mesmo no exterior.

A bibliografia, apesar de diversificada, destina uma maior atenção as pinturas murais de períodos mais remotos, como as pinturas das tumbas dos faraós no Egito, as pinturas das tumbas etruscas na Itália, das ruínas da cidade de Herculano e Pompéia, das grutas chinesas budistas de Mogao, etc. Uma produção em número menor, mas também existente é a da arte mural dos séculos subseqüentes, chegando até início do século XX com o muralismo mexicano.

\footnotetext{
${ }^{121}$ Existem diversos grupos de trabalho nas respectivas Associações Internacionais de profissionais que atuam na área de conservação e restauro, o do ICOM-CC, Working Group Mural, Stone, and Rock Art; o do ICOMOS com o Comitê Científico Internacional de Pintura Mural, entre outros.
} 
Essa bibliografia técnica e científica de trabalhos de conservação e restauração é geralmente produzida a partir de grandes projetos desenvolvidos por instituições de renome na área a nível internacional, como o Getty Conservation Institute (EUA), o Cortauld Institute of Art (Inglaterra), o ICCROM (Italia), o Istituto Centrale per il Restauro (ICR), entre outras, que atuam em colaboração com instituições e centros de pesquisa em universidades, vinculados e/ou particulares, para poderem melhor estruturar um campo de estudos e de ação nos diferentes países solicitantes de cooperação técnica, ou de interesse das respectivas pesquisas em desenvolvimento.

Os trabalhos estão sempre relacionados aos bens culturais de interesse mundial, que estão sobre a proteção da UNESCO através do World Heritage List (Lista do Patrimônio Mundial da UNESCO) e envolvem equipes multidisciplinares.

$\mathrm{Na}$ bibliografia específica sobre pintura mural está o livro, Conservation of Wall Paintings de Paolo Mora, Laura Mora e Paul Philippot, aqui já citado em outro capítulo e publicado em sua primeira versão em francês em 1977, depois traduzido para o inglês em 1984. O livro foi publicado pela editora Butterworths dentro da coleção Series in Conservation and Museology com apoio do ICCROM e do International Institute for Conservation of Historic and Artistic Works (IIC). O livro é um compendio sobre a pintura mural, sua evolução histórica, técnicas, processos de degradação, métodos de diagnóstico e intervenção, glossário de termos e é fundamental para profissão e considerado o "livro referência" dos profissionais da área, ainda hoje, em diferentes países.

O seu conteúdo está dividido em áreas de interesse como: pintura mural e arquitetura, conservação com destaque para estudo de períodos específicos e regiões, métodos de exame, documentação, constituição de reboco, pigmentos, história das técnicas, causas de deterioração, limpeza, consolidação e fixação, problemas de apresentação estética, tratamento de lacunas, etc. Portanto, através dele é possível se ter uma dimensão da diversidade de trabalhos e publicações, já na época existentes (1984), relativas à área de pintura mural.

The Conservation of Wall Paintings: Proceedings of a Symposium Organized by the Courtauld Institute of Art and The Getty Conservation Institute é outra publicação de 1991, resultante de um Simpósio realizado pelo Courtauld Institute of Art (Inglaterra) em 1985, como parte do curso de pós-graduação em conservação e 
restauração de pintura mural em colaboração com o Getty Conservation Institute (EUA). Reúne uma série de profissionais de diversos países como Inglaterra, Itália, Alemanha e EUA e seus respectivos trabalhos, destacando aqueles desenvolvidos na Tumba de Nefertari, na Capela Brancacci e na Capela Sistina, em suas diferentes fases desde o planejamento, diagnóstico até tratamento e monitoramento.

A revista Newsletter do Getty Conservation Institute $(G C l)$ tem alguns números dedicados a divulgação de trabalhos de preservação de mural (Mural Conservation vol. 18.2 de 2003) com artigos relacionados a preservação de murais modernos e contemporâneos e introduzindo questões conceituais relativas a preservação deste tipo de arte, mais recente, em espaços públicos. Outro número da revista é dedicado a preservação de mosaicos (Mosaic Conservation vol. 21.1 de 2006) com uma reflexão sobre a prática da preservação desta arte durante os ultimos trinta anos, ocorridas também em função das reflexões e alterações da prática de preservação da pintura mural. Recentemente foi publicada Conservation Perspectives decorated architectural surfaces vol.25.2 de 2010 que está relacionada à pintura mural com reflexões sobre as perspectivas e formação na área.

Outra significativa publicação, também resultante de um Seminário desenvolvido pelo ICCROM em 1999 foi o GraDoc (Graphic Documentation Systems in Mural Painting Conservation) envolvendo profissionais de vários países para discussão sobre o registro e documentação de pintura mural realizados em diferentes partes do mundo suas técnicas, dificuldades, necessidades e perspectivas futuras.

Apenas algumas publicações foram aqui mencionadas, entre tantas outras existentes, pois elas podem ser consideradas como referências e como identificadoras das tendências da atuação dos profissionais nesta área da preservação da arte mural. A diferença de enfoque e a metodologia adotada por profissionais no exterior, nem sempre corresponde a realidade e as possibilidades de outros países. Todavia, o crescente movimento em torno da adoção de uma política de conservação preventiva tem se intensificado nas ultimas décadas e colaborado para a mudança gradativa de postura com relação à área, exigindo o envolvimento cada vez maior de diferentes profissionais no estudo de obras de interesse do patrimônio cultural. Tendência que, apesar de num ritmo bem mais lento está se inserindo na nossa realidade também. 


\section{CAPITULO V - Qualidade em Intervenções de Conservação e Restauração}

\subsection{Conceito de Qualidade}

O conceito de qualidade como esclarecem CARPINETTI, MIGUEL, GEROLAMO (2009) passou por uma evolução. Até 1950, a qualidade era sinônimo de perfeição técnica e, após 1950, além da perfeição técnica, ela adquire também o requisito de maior adequação as necessidades impostas pelo cliente. $O$ atual conceito de qualidade relaciona a satisfação do cliente quanto à adequação do produto ao uso.

A norma internacional ISO ${ }^{122}$ 9000:2000, define a qualidade como sendo "o grau no qual um conjunto de características inerentes satisfaz requisitos".

O objetivo das normas é permitir que determinados requisitos sejam cumpridos pelas empresas ou partes envolvidas em um processo tanto de produção de um produto quanto de produção de serviços. Portanto, elas são aplicáveis a diferentes seguimentos das organizações sociais.

Essa satisfação é definida pelos autores como aplicável a qualidade de um produto, cujos itens que the conferem esta característica são vários, dentre os quais destacam-se: mantenabilidade (ou manutenibilidade), durabilidade,conformidade, instalação e orientação de uso, assistência técnica, interface com o usuário, interface com o meio ambiente, estética e qualidade percebida e imagem da marca.

Os autores também destacam que as relações econômicas associadas à vida útil do produto e ao seu custo, devem ser consideradas, para que haja viabilidade na aquisição do produto por parte do usuário considerando a confiabilidade, a facilidade de manutenção a durabilidade e a eficiência do produto.

Uma vez definida a qualidade de um produto ou serviço, o exercício de sua gestão, ou melhor, o controle para que as especificações sejam cumpridas no processo de fabricação ou no processo de serviços é estabelecido pela gestão da qualidade.

Conceito de gestão de qualidade também evoluiu, assim como o conceito da qualidade. Antes ele era vinculado somente ao processo de fabricação do produto e

122 ISO é a sigla da International Organization for Standardization fundada em 1946 com sede em genebra Suiça. Esta é uma organização que reune associações relacionadas a normalização de diferentes nações com finalidade de estabelecer normas e padrões em diversas áreas da sociedade. A associaçõe que representa o Brasil é a ABNT Associação Brasileira de Normas Técnicas. 
posteriormente passou a incluir todas as etapas, antes do processo de produção, durante e a etapa posterior ao processo de produção.

A inclusão de todas estas etapas, além do próprio processo de produção ocorreu conforme mencionam CARPINETTI, MIGUEL, GEROLAMO (2009) em função do trabalho desenvolvido por Juran (1990) e Feigenbaun (1991) ${ }^{123}$ que permitiu, em anos posteriores, a estruturação de um sistema de garantia e controle de qualidade, o que hoje é chamado de gestão de qualidade.

As normas ISO 9000 publicadas em 1987, são as normas relativas à qualidade e tem sofrido alterações ao longo dos anos. Elas constituem atualmente um grupo composto pelas normas relativas ao sistema de gestão de qualidade: sobre fundamentos e vocabulário (ISO 9000:2005); sobre requisitos (ISO 9001:2008); sobre as diretrizes para melhoria de desempenho (ISO 9004:2000)

As várias revisões pelos quais tem passado as normas buscam o aperfeiçoamento e adequação às novas exigências.

As diretrizes da aplicação de determinados parâmetros de avaliação no mercado da produção e de serviços difere em relação à aplicação no patrimônio cultural.

A qualidade nesta área está associada à aplicação de conceitos e princípios, ao uso de materiais adequados e compatíveis que permitam uma durabilidade do produto (a intervenção no bem cultural) através dos serviços prestados.

Diferentemente do que ocorre no mercado em geral a gestão da qualidade nesta área não está associada a uma competitividade de empresas visando o seu destaque por apresentar um diferencial, pois o número de empresas existentes é relativamente pequeno, mas objetiva a implantação de parâmetros mínimos que possam auxiliar na avaliação dos serviços prestados e no produto final apresentado.

Algumas experiências mais próximas da realidade do mercado para o qual a estrutura foi criada têm sido vivenciadas pelas empresas de construção civil, já submetidas às exigências e em busca de uma certificação de qualidade.

123 JURAN, J.M. Juran planejando para a qualidade. São Paulo: Pioneira, 1990. FEIGENBAUN, A. V.Total quality control. New York: MacGraw-Hill, 1991. 


\subsection{Conceito de Gestão}

A utilização e adaptação de modelos ou mesmo a criação de parâmetros para as aplicações no planejamento e controle de qualidade no mercado da construção civil é, portanto, cada vez mais freqüente e tende a se propagar para os outros segmentos a ela relacionados.

O implementação de um processo regulatório agrega a credibilidade e a confiança nas fontes administrativas e executoras e conseqüentemente a aceitação e o respeito pela sociedade.

O processo de normalização de determinada atividade ou execução de produto só irá ocorrer mediante uma demanda, que pode ser realizada por qualquer pessoa interessada, sem que ela tenha que estar vinculada ao governo ou ao setor produtivo.

Ele consiste no encaminhamento da demanda ao setor técnico da $\mathrm{ABNT}^{124} \mathrm{e}$ na elaboração de temas a serem normalizados, que passarão por consulta nos respectivos setores envolvidos. Um texto é elaborado por uma comissão de estudos composta por representantes de diversas áreas correlatas e, depois, é feita uma consulta nacional à sociedade, que pode ou não fazer objeções ou sugestões e o projeto pode ser aprovado, ou caso não haja um consenso, ele pode ser cancelado.

$O$ estabelecimento de normas segundo a ABNT, já vem contribuindo com reflexos importantes não só na economia, mas também na sociedade. Ela justifica sua atuação na elaboração de normas considerando que:

\footnotetext{
"As normas ABNT contribuem para o desenvolvimento, fabricação e fornecimento de produtos e serviços mais eficientes e seguros. Elas tornam 0 comércio mais fácil e justo entre países. Elas dotam os governos com embasamentos técnicos para a legislação relativa a saúde, segurança e meio ambiente. Elas ajudam na transferência de tecnologia para o desenvolvimento do país. As normas ABNT também servem para salvaguardar consumidores e usuários em geral - de produtos e serviços - assim como para simplificar suas vidas." (ABNT, Normalização) ${ }^{125}$
}

\footnotetext{
${ }^{124}$ ABNT, a Associação Brasileira de Normas Técnicas é a responsável pelo desenvolvimento das normas técnicas brasileiras.

${ }^{125}$ Informações obtidas no site da ABNT item Normalização. Disponível em:

$<$ http://www.abnt.org.br/m3.asp?cod pagina=961>. Acesso em: 20 mar. 2011.
} 
Através da implantação de normas aplicadas não só na execução de produtos, mas também relacionadas a processos de serviços, é possível reduzir e até mesmo evitar a incompatibilidade de serviços, a baixa qualidade e garantir a confiabilidade.

A ABNT relaciona dez vantagens para o emprego de normas que seguem listadas: 1) Melhorar seus produtos ou serviços; 2) Atrair novos consumidores; 3) Aumentar sua margem de competitividade; 4) Agregar confiança ao seu negócio; 5) Diminuir a possibilidade de erros; 6) Reduzir seus custos de negócio; 7) Tornar seus produtos compatíveis; 8) Atender a regulamentos técnicos; 9) Facilitar a exportação de seus produtos; 10) Aumentar suas chances de sucesso.

A solicitação para implantação de normas não está diretamente relacionada com o possível reconhecimento profissional, ${ }^{126}$ mas sim com a demanda do mercado pela criação dessas normas. Portanto, elas poderiam ser criadas sem que a profissão que executa as atividades relacionadas fosse ou não reconhecida e regulamentada.

No caso dos projetos de conservação e restauração de bens integrados, que apresentam certas especificidades, os princípios destacam que as questões técnicas estão relacionadas às necessidades individuais de cada obra e, portanto, não é possível criar um método geral de atuação. Entretanto, podem ser desenvolvidos procedimentos padrões de registro e seqüência de atividades a serem executadas.

Isso facilitará a análise de projetos pelos técnicos e permitirá uma uniformização e comparação de atividades desenvolvidas o que possibilita a identificação de eventuais etapas não cumpridas ou alteradas.

Todavia, outros métodos têm sido adotados na área de patrimônio. Estudos têm sido realizados por instituições internacionais para a criação de modelos e guias preparados para a utilização desse tipo de atividade nesse campo específico.

$\mathrm{Na}$ área de patrimônio é importante destacar a importância do planejamento na administração e no processo de preservação, como instrumento básico de regulação e de garantia de qualidade do trabalho de conservação e restauração.

O quadro da preservação da área de murais até aqui evidenciado, permite constatar que não existe uma pensamento único e homogêneo na atuação prática e que, portanto, as diferenças existentes relacionam-se com diversos fatores.

\footnotetext{
${ }^{126}$ Segundo informações fornecidas a autora por funcionário do setor de normalização da ABNT.
} 
$\mathrm{Na}$ implantação de um processo de gestão visando uma melhor qualidade, devemos considerar quem são os membros articuladores do processo, a expectativa de cada um em relação as atividade de conservação e restauração e, também as diversas fases do processo.

A realização do trabalho de intervenção em uma obra, como já anteriormente mencionada, envolve três elementos, o contratante do trabalho (instituições públicas, instituições religiosas, particulares), o executor (conservador-restaurador) e o financiador (patrocinador, investidor, empresas, indivíduos ou a comunidade).

A qualidade e eficácia da atuação devem ser analisadas dentro do processo de intervenção como um todo e não restringir-se a fase final, pós-execução.

No âmbito da administração da preservação do patrimônio cultural STOVEL (2002) menciona que a gestão deve envolver uma série de etapas e indicadores que proporcionem uma correta avaliação para a tomada de decisões em relação a planos de ação. Ele reconhece o monitoramento como elemento do processo de gestão e o define como uma atividade realizada com objetivo de obtenção de informações e possíveis correções para melhoria de desempenho e, também, para a aplicação em macro escala para sítios, territórios, ${ }^{127}$ etc.

No caso da aplicação para os bens patrimoniais individuais, STOVEL (2002) destaca que "[..] o monitoramento envolve a medição de qualidade e condições nas quais os responsáveis pelo gerenciamento dos bens patrimoniais podem focar seus esforços." O autor ainda considera que "Com relação aos bens patrimoniais individuais, o monitoramento pode envolver esforços para medir mudanças em três áreas: a avaliação das forças e pressões externas aos sítios; a avaliação do 'estado de conservação'(condição atual dos sítios); avaliação da eficácia do gerenciamento e/ou das ações levadas a efeito nos sítios." STOVEL (2002, p.175). ${ }^{128}$

A atividade de monitoramento deve definir um propósito e também os instrumentos indicadores (parâmetros) para a verificação e definição das necessidades. A base do monitoramento é a observação e para executá-la é possível se utilizar de diferentes sistemas. Os indicadores segundo STOVEL (2002)

\footnotetext{
${ }^{127} \mathrm{O}$ autor trabalha com questões relacionadas ao monitoramento para gerenciamento e conservação do patrimônio cultural. Apesar de referir-se a sítios e territórios considerando a conservação integrada, pode-se também relacionar à escala menor aplicada ao bem imóvel individual e seus bens integrados.

${ }^{128}$ Apesar do uso do termo sítio considerando a ação sobre áreas maiores, deve-se também salientar a aplicabilidade para bens individuais em menor escala, no caso em estudo neste trabalho, as obras murais.
} 
devem ser definidos de forma integrada para compor o contexto gerencial de uma instituição e não como algo isolado.

As vantagens obtidas através da implantação do monitoramento atingem os três elementos já mencionados: o primeiro referente às instituições responsáveis pela preservação, garantindo efetividade de ações, redução de custos, melhor aplicação de recursos disponíveis, ou a serem captados, o aprimoramento da tecnologia e a credibilidade; o segundo, para os agentes executores ele serve de instrumento de avaliação das atividades desenvolvidas sobre 0 bem e do comportamento dos materiais empregados, os métodos utilizados de intervenção sobre o bem cultural; o terceiro, em relação à comunidade envolvida com o bem, representa uma oportunidade de participação da comunidade 0 do seu reconhecimento da importância das atividades de preservação.

A comunidade é um importante elemento de sustentação das ações de preservação e conservação, sem a sua participação nas atividades o ciclo se torna obsoleto e retorna-se ao mesmo problema de descontinuidade e perda de investimento. A captação da participação e o interesse da comunidade no processo de preservação do patrimônio não é uma tarefa fácil, depende das partes envolvidas e do contexto em questão. Porém, é uma etapa que não pode ser ignorada e geralmente não são investidos recursos neste tipo de ação.

STOVEL (2002) menciona ainda que agregado a uso do monitoramento para avaliação do estado físico deve ser feita também a investigação do valor do significado do sítio (local), ou seja, de que forma a alteração no estado físico alterou o valor do bem em seu significado e a sua autenticidade.

A autenticidade é determinada pela materialidade, pelo desenho, pela forma, pelo contexto pelas tradições técnicas e sentimentos e considerando a integridade de significados, valores e mensagens.

Verifica-se que as ações técnicas não estão, portanto, desvinculadas dos valores atribuídos ao bem, mas são por eles determinadas.

Um sistema de planejamento inclui diferentes etapas que implicam, no conhecimento geral do objeto de estudo, até as medidas a serem incorporadas para um eficiente funcionamento do sistema. 
"Os sistemas de planejamento usados para projetar ações e estratégias geralmente empregam processos e princípios similares, quer sejam usados no gerenciamento de organizações, agências governamentais, ou sítios patrimoniais." (STOVEL, 2002)

Em geral os sistemas incluem etapas relacionadas à coleta de informações, identificação das necessidades, identificação de alterações a serem feitas, de áreas a serem alteradas, seleção de critérios a serem considerados, até as ações a serem implantadas.

Esse planejamento visa atingir determinados padrões mínimos, ou critérios necessários de atuação com intuito de garantir a aplicabilidade em serviços incluindo, portanto, também a prestação de serviços de conservação e restauração.

\subsection{Aplicação em Conservação e Restauração}

$\mathrm{Na}$ área do patrimônio cultural há mais de uma década já foram expressas em forma de documento as exigências e necessidades da atuação da prática interventiva no patrimônio europeu com respeito a sua diversidade nacional e regional, que foram formalizadas através do documento de Pavia em 1997.

O documento, elaborado em 1997, em uma reunião de profissionais ligados a conservação e restauração estabeleceu treze recomendações necessárias para garantir a preservação do patrimônio cultural, dentre elas estavam ações que incentivassem o reconhecimento e promoção das atividades de conservação e restauração, que permitissem estabelecer o intercâmbio interdisciplinar entre ciências humanas e ciências naturais, bem como o estabelecimento de um quadro regulatório para garantir a qualidade da intervenção no patrimônio cultural, ou seu entorno, visando evitar a ação e impacto das forças do mercado.

A finalidade desse quadro era de permitir a regulação de empresas, firmas e profissionais, que atuavam na conservação e restauração do patrimônio além de estruturar as necessidades específicas de projetos de conservação e restauração e um glossário com definições conceituais.

Este documento estabeleceu as diretrizes para o perfil do profissional de conservação e restauração e sugeriu que as medidas fossem implantadas. 
Essas recomendações já vêm sendo implantadas e seguidas e merecem da nossa parte especial atenção como experiência e referência de posturas preservacionistas, que na realidade se iniciam pela própria formação do profissional.

Embora o documento tenha sido estruturado numa outra realidade, onde a formação profissional já ocorre em nível universitário há vários anos, o documento nos permite refletir sobre aspectos que devem ser introduzidos também na realidade brasileira independentemente se as bases estruturadoras de uma formação específica em nível universitário estejam ainda se formando.

O item 11 elaborado no documento propõe o estabelecimento de um quadro regulatório para garantir a qualidade da intervenção no patrimônio cultural ou seu entorno, a fim de evitar o impacto da forças do mercado. O quadro regulatório, conforme já citado, deve englobar providências relacionadas à competência de firmas ou equipes de profissionais nas áreas de projetos de conservação e restauração e, conjuntamente, elaborar uma gama de especificações para projetos de conservação e restauração.

Embora aplicadas em âmbito geral do patrimônio, justamente por se referirem a questões primordiais (formação, o perfil do profissional, código de ética), essas recomendações, se implantadas, atingem todos os campos da atividade prática, permitem criar base sólidas de referência e padrões de atuação nos projetos de conservação e restauração que possam orientar a conduta dos profissionais que se dedicam a esta área e facilitar o controle de qualidade dos projetos e a avaliação por parte das instituições responsáveis pela preservação.

Lembramos que com exceção dos arquitetos e arqueólogos a profissão de conservador/restaurador em vários países europeus não é reconhecida. Portanto, problemas de ordem semelhantes aos nossos também existem, apesar de termos regulamentado, recentemente, a profissão de conservador-restaurador.

A diferença reside no fato de que existe uma gama maior de escolas de formação na Europa, o que contribui para o abastecimento de profissionais no mercado com um nível diferenciado de formação.

No contexto Brasileiro talvez essas questões já estejam um pouco mais avançadas ou trabalhadas na área arquitetônica, em função da profissão ser 
regulamentada ${ }^{129}$ e da existência de uma Decisão Normativa do CONFEA no 83, de 26 de setembro de 2008, que designa como necessário o arquiteto para a execução de projetos de conservação e restauração e para a administração deste tipo de obra. Ela estabelece os parâmetros "legais" para a capacitação de coordenação e execução de trabalhos de conservação e restauração de bens imóveis, que estão restritos a carreira do arquiteto.

Todavia, no campo da formação desses arquitetos verifica-se que estão sendo introduzidas uma série de disciplinas nas faculdades no nível da graduação e pós, no intuito de abranger uma formação teórica mínima na área.

O campo regulador, no entanto, se encontra restrito as intervenções em edificações, bens culturais imóveis, não sendo aplicado aos bens culturais integrados e móveis.

As causas desta inexistência de normas específicas para trabalhos de conservação e restauração de bens integrados e móveis estão relacionadas, a princípio, com o não reconhecimento da profissão de conservador e restaurador. ${ }^{130} \mathrm{~A}$ profissão não é reconhecida também em vários países europeus. Todavia, existem códigos de ética que estabelecem diretrizes para o exercício da profissão.

A criação de um código de ética para o exercício da profissão no contexto brasileiro foi realizada em 2005. Na realidade a profissão aqui está passando por processo de mudanças graças aos esforços de profissionais da área que se dedicaram a sua regulamentação. Além das conquistas na regulamentação da profissão, um outro passo nesse sentido já foi dado com a criação do primeiro curso de graduação em conservação e restauração de bens culturais móveis e integrados da Universidade Federal de Minas Gerais em 2008, mas que ainda não supre a necessidade de formação específica em murais. ${ }^{131}$ Muitos cursos de formação

\footnotetext{
${ }^{129}$ Em 21 de dezembro de 2010 foi aprovado o projeto de lei da Câmara regulamentando a profissão de Arquiteto Urbanista. Essa proposta substitui a legislação atual e deve passar pela sanção presidencial e desvincular os arquitetos do então CONFEA para a criação do Conselho de Arquitetos e Urbanistas, CAU/BR no âmbito Federal. Mudanças estão ocorrendo na estrutura do quadro profissional para área arquitetônica.

${ }_{130}$ Foi aprovado em 17 de Novembro de 2010, na comissão de trabalho o projeto de lei, apresentado pelo relator Dep. Mauro Nazif, que regulamenta a profissão de conservador /restaurador. Disponível em:

$<$ http://www2.camara.gov.br/agencia/noticias/trabalho-e-previdencia/151352-comissao-regulamentaprofissao-de-conservador-restaurador.html>. Acesso em: 05 dez. 2010.

${ }_{131}$ Curso que até então tinha um status de curso de especialização exigindo do profissional uma formação básica de graduação em diferentes áreas como: história, arquitetura, artes plásticas e áreas afins.
} 
técnica em conservação-restauração têm sido criados nos últimos anos em diversas partes do país.

No continente europeu questões relacionadas à formação, atuação profissional e avaliação das práticas, e padronização já vem sendo trabalhadas no intuito de se conseguir uma melhor qualidade do profissional e da atividade prática.

$\mathrm{Na}$ realidade o controle de qualidade nos trabalhos de conservação e restauração deve seguir o mesmo padrão dos estabelecidos para as distintas áreas onde o conceito já é aplicado sendo que a área mais próxima é a da construção civil, que já tem as normas para atuação do profissional no campo da conservação e restauração, de bens imóveis, mas não com relação à qualidade.

A avaliação e controle não devem ser realizados após a execução dos trabalhos, mas introduzidos e considerados já na fase inicial da estruturação dos projetos ou trabalhos de conservação e restauração, de forma a permitir um acompanhamento minucioso das etapas evolutivas e não uma inspeção e/ou checagem final. $\mathrm{O}$ que dificultaria ou mesmo inviabilizaria quaisquer alterações de natureza conceitual e técnica caso se fizesse necessário no projeto ou nas atividades a serem executadas.

Essa etapa inicial, que possivelmente exigirá mais tempo em planejamento e preparativos por parte do profissional que irá executar a obra, no entanto garantirá significativos ganhos de tempo e custos para a preservação do patrimônio, planejamento e a gestão da obra.

As práticas de melhoria de qualidade vêm se estruturando no IPHAN desde a abertura de edital para a contratação de serviços especializados para implantação do programa de gestão pela melhoria contínua, enfatizando a gestão de processos dentro da instituição ${ }^{132}$. Isso revela que existe uma busca interna para 0 aperfeiçoamento das atividades, viabilização do planejamento, redução de prazos acompanhamento e controle de projetos no âmbito institucional e que a tendência é externar este processo para a atuação técnica.

O interesse pela qualidade nos serviços de conservação e restauração já atingiu as esferas federais resultando na realização do I Seminário Qualidade na

132 IPHAN Edital de tomada de preços no 01/2009, do processo ํㅜ 01450.006730/2009-25 com objetivo de contratação de prestação de serviços especializados para implantação do Programa de Gestão pela Melhoria Contínua com ênfase em gestão de processos do Instituto do Patrimônio Histórico e Artístico Nacional - IPHAN. 
Conservação de Monumentos, promovido pela Coordenação de Conservação de Bens Imóveis do Departamento de Patrimônio Material e Fiscalização do Iphan, realizado entre os dias 17 e 21 de agosto de $2009^{133}$, no auditório do Palácio Gustavo Capanema no Rio de Janeiro, confirmando a necessidade crescente de um aprimoramento da qualidade do trabalho técnico na preservação de monumentos.

$O$ intuito do encontro era de orientar a atuação técnica, principalmente no que se refere à produção de conhecimento na área de conservação do patrimônio cultural. Orientação que se espera que tenha reflexos também na atuação prática em relação aos bens integrados.

\begin{abstract}
"Entre as recomendações mais importantes destacam-se: dar prosseguimento à política de convênios e ampliar a interlocução interinstitucional; inserir o acervo protegido no universo educacional do país; implementar a qualificação da formação básica de profissionais de arquitetura em particular da elaboração de projetos; considerar-se a possibilidade de adaptação de uso diante dos novos contextos, de que nem todo o patrimônio edificado será mantido pela economia do turismo; por meio de ações informativas reforçar o diálogo e a relação com a sociedade; estimular pesquisas científicas sobre conservação tendo por matriz o conhecimento gerado na atuação de rotina das instituições; distribuir responsabilidades, com os proprietários de imóveis, especialmente, os edifícios religiosos; promover a participação do Iphan na gestão do banco de projetos apresentados ao Pronac; e, dar continuidade à realização dos encontros de capacitação técnicos do Iphan e parceiros, realizando-os, preferencialmente, no primeiro semestre de cada ano a fim de não chocar com a execução financeira e garantir a presença de todos os servidores envolvidos na rotina de fiscalização e acompanhamento técnico." (ASCOM, 2009)
\end{abstract}

Pode-se dizer que a criação de um modelo básico padronizado com uma estrutura formada por uma base de dados para registro e acompanhamento é algo necessário não só, do ponto de vista institucional, como para a administração e gerenciamento dos bens, mas também, para as empresas como forma de garantir um controle de um padrão de qualidade.

Um trabalho de conservação e restauração de bens integrados deve contemplar as seguintes fases: Estudo do objeto/obra; Planejamento do projeto; Execução do Projeto; Avaliação do projeto; Planejamento de Manutenção.

\footnotetext{
${ }^{133}$ Notícia divulgada em 14.12.2009 pela ASCOM. Disponível em: $<$ http://portal.iphan.gov.br/portal/montarDetalheConteudo.do?id=14904\&sigla=Noticia\&retorno=detalh eNoticia>. Acessado em: 30 jan. 2010.
} 


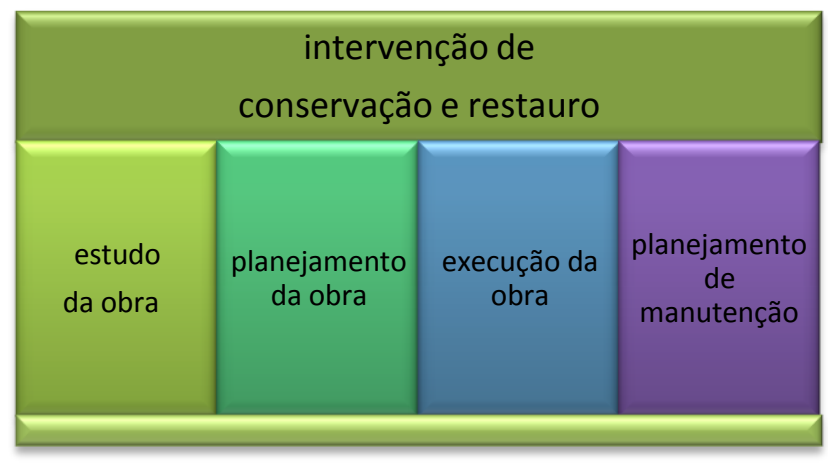

Figura 77 Etapas de um trabalho de conservação e restauro

Em cada etapa devem ser desenvolvidas atividades específicas:

1. Estudo da obra: levantamento de dados, identificação, caracterização, exames e diagnóstico, documentação.

2. Planejamento da obra: recursos materiais e equipamentos, recursos humanos (mão de obra), prazos, instalação de canteiro de obras, documentação.

3. Execução da obra: registro de atividades (documentação).

4. Planejamento de manutenção da obra: estabelecimento de prazos e freqüências das atividades, registro de atividades (documentação).

Com relação à formação do profissional conservador/restaurador reconhecemos a necessidade de uma formação mais específica na área de murais, que ainda se encontra pendente, caso contrário, o campo de atuação permanecerá sempre no limite entre a arquitetura e os ofícios de pintura artesanal.

Considerando as informações das diversas fontes e os resultados da pesquisa já exposto em capítulos anteriores fica evidente a necessidade de um trabalho de inventário sistematizado e da abordagem de aspectos básicos já mencionados no documento de Pavia (1997), sobre a estruturação de um glossário de conceitos com especificações mínimas de documentação e outros elementos em projetos de conservação e restauração, que permitam de uma forma mais clara objetiva e fundamentada em critérios mínimos obter parâmetros de comparação e evitar que abordagens equivocadas na área possam passar despercebidas. 


\section{CAPITULO VI - Diretrizes.}

\subsection{Novas perspectivas e Desafios da preservação da arte mural}

As novas perspectivas da preservação da arte mural estariam relacionadas às recentes configurações que esta 'arte' pode vir a ter, assumindo um caráter possivelmente mais efêmero e dinâmico.

Essa forma de expressão dinâmica e efêmera adquire diferentes nomenclaturas no meio como a de arte urbana, arte de rua, ou grafite ${ }^{134}$.

Apesar de vários historiadores da arte não reconhecerem essa forma de expressão como 'arte', e nem mesmo alguns grafiteiros a enquadrarem nesta categoria, é possível e necessário reconhecer que essa forma de expressão já tem se destacado no espaço urbano e mesmo adquirido um certo reconhecimento por parte da comunidade, de alguns seguimentos da sociedade, de alguns órgãos administrativos e, até mesmo, da comunidade internacional.

O destaque aqui realizado em relação ao tema apenas evidencia a possível atenção a uma nova realidade que desponta neste contexto e não a uma posição ou opinião da autora já determinada sobre o assunto.

Assim como novas perspectivas surgiram em relação à conservação e restauração da arte contemporânea, torna-se evidente que possíveis necessidades venham a surgir em relação à área de obras murais.

A preservação deste tipo de expressão artística, a arte de rua, arte urbana ou grafite, executado sobre a parede ou muro, exigirá novas posturas e reflexões sobre esse 'novo conceito de arte mural', que talvez se aproximem das posturas que estão tendo alguns profissionais em relação ao tema de murais comunitários nos Estados Unidos (EUA), onde nos anos 70 e 80 se desenvolveram uma série de murais e, que tem gerado controvérsias com os restauradores que seguem a 'linha tradicional' ou 'clássica' da restauração. As discussões já vêm se estendendo e, em 2003, vários artigos e experiências foram publicados sobre $o$ assunto enfatizando os programas realizados por associações e agências em relação à preservação dos murais.

\footnotetext{
134 A grafia do termo adotado pela autora está em português e não na língua italiana que seria graffiti plural de graffito (pintura ou desenho em um suporte).
} 
Em São Paulo, em função da grande repercussão que a 'arte de rua', 'arte urbana', ou grafite tem alcançado hoje em dia, bem como da sua identificação com o público jovem e do incentivo que tem sido dado a sua divulgação ${ }^{135}$ e preservação, mesmo por parte da própria prefeitura, ${ }^{136}$ nada mais coerente do que pensar na divulgação das primeiras iniciativas de arte mural existente na cidade, para que a população possa compreender o significado e valor deste tipo de representação artística inserido na edificação e no espaço urbano.

O mapeamento dos grafites em SP e a sua preservação como propunha em janeiro de 2009 o Secretario de Coordenação das Subprefeituras da PMSP ${ }^{137}$ Andrea Matarazzo, configuraria uma ação pontual, dispersa e ainda o estabelecimento de uma lacuna maior em relação ao nosso patrimônio, principalmente em relação à arte mural, que conforme estudado neste trabalho teria um grande potencial a ser explorado, tanto patrimonial, quanto turístico e de desenvolvimento da educação patrimonial.

\footnotetext{
${ }^{135}$ Para maiores informações sobre ações de divulgação deste tipo de expressão artística que tem sido valorizado como forte componente do turismo em SP, ver reportagem no Jornal a Folha de São Paulo disponível em:

< http://www1.folha.uol.com.br/folha/ilustrada/ult90u579180.shtml> Acesso em: 25 jul. 2010.

${ }^{136}$ Informações adicionais sobre ações de preservação do grafite por parte da PMSP. Disponível em: $<$ http://www.estadao.com.br/estadaodehoje/20090116/not imp307995,0.php> e em outros endereços como <http://g1.globo.com/Noticias/SaoPaulo/0,,MUL701064-5605,00-

PREFEITURA+DE+SP+QUER+RELACAO+DE+GRAFITES+QUE+DEVEM+SER+PRESERVADOS.h

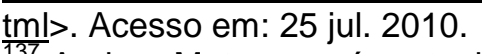

${ }^{137}$ Andrea Matarazzo é o atualmente 2011 o Secretario de Estado da Cultura do governo de Geraldo Alckmin.
} 


\section{SP quer mais grafites no Minhocão}

Pintadas, colunas virariam galeria de arte

16 de janeiro de 2009 | Oh 00

Luísa Alcalde, SÃO PAULO - O Estadao de S. Paulo

Uma proposta da Prefeitura de São Paulo pretende transformar o vão livre do Elevado Costa e Silva, o Minhocão, na região central, em uma galeria oficial do grafite. As colunas de sustentação do elevado receberiam obras de grafiteiros da cidade. O secretário de Coordenação das Subprefeituras, Andrea Matarazzo, já articula o projeto e, na próxima semana, se reúne com artistas para discutir a ideia.

O secretário quer saber o que eles pensam sobre essa forma de arte e quais obras espalhadas nos muros da cidade podem ser consideradas grafite. Segundo Matarazzo, a Prefeitura não vai patrocinar os trabalhos financeiramente nem bancar material, como tintas, sprays e pistolas. "Seria uma adesão espontânea", explicou o secretário. Nesse caso, os painéis teriam de estar sempre em ordem e serem cuidados e retocados pelos autores para não se degradarem.

Matarazzo também pretende mapear os grafites existentes na cidade com a ajuda dos artistas e, posteriormente, colocar o roteiro em um catálogo. As obras seriam ainda identificadas com placas com os nomes dos autores.

Dessa forma, as empresas terceirizadas que prestam serviços de manutenção para a cidade saberiam que se tratam de painéis autorizados e não os apagariam, como ocorreu há uma semana na Avenida Radial Leste, com um painel dos irmãos Otávio e Gustavo, da dupla de artistas Os gemeos apagado por engano.

"O que têm acontecido é que murais muito degradados, com pichações por cima, feios, estragados acabam recebendo tinta por cima", explicou o secretário. Segundo Matarazzo, nem todos grafites sem autorização são apagados.

O grafiteiro Eduardo Kobra apoia a iniciativa da criação da galeria do grafite. "Se puderem guardar a obra para que não pichem e não se deteriore é uma proposta interessante", afirmou. Ele defende que o espaço seja entregue a grafiteiros variados e não restrito a grupos para ser explorado de forma pluralista.

Figura 78 Reportagem publicada no Jornal a Folha de São Paulo. (grifo nosso) Fonte: Disponível em: < http://www1.folha.uol.com.br/folha/ilustrada/ult90u579180.shtml> 
Uma vez realizado um inventário geral das obras murais, já realizado na dissertação de mestrado, especialmente o das obras dos artistas do Grupo Santa Helena, o grande desafio que se impõe como princípio básico da conservação, se consideramos as obras em estudo neste trabalho, seria a sua divulgação, para o conhecimento e reconhecimento por parte da comunidade.

Menciona-se a comunidade como sendo aqueles que especificamente tem contato direto com as obras ou que de alguma forma usufruem de forma esporádica desta manifestação estética. Neste contexto no qual as obras não se encontram ainda com nenhum tipo de proteção legal a ação dos seus responsáveis e da comunidade que direta ou indiretamente está envolvida com elas desempenha um papel significativo. Portanto, ações relacionadas à comunicação e divulgação se tornam primordiais e perfeitamente adequadas para uma realidade urbana da dimensão da nossa.

Em relação às obras estudadas devemos considerar duas situações distintas, a da existência de obras murais executadas em períodos e em locais diversos, desde os locais residenciais, casas ou edifícios com espaços ou acesso restrito, até aquelas executadas nos espaços públicos.

Grande parte das obras se encontra na região central da cidade, ou em áreas próximas relativamente próximas umas das outras, principalmente aquelas executadas após a década de 1950 pelo artista Clóvis Graciano.

A região central tem passado por um processo de revitalização e é perfeitamente aceitável e aplicável a iniciativa de valorização da área através do destaque dados aos espaços que apresentam essas obras murais.

Um novo circuito artístico cultural intitulado a "A rota do mural" poderia ser criado a exemplo de outras iniciativas que já vem sendo desenvolvidas no centro, pela Associação Viva o Centro e pela Secretaria Municipal de Cultura da PMSP como, por exemplo, o caso das visitas monitoradas no Cemitério da Consolação. ${ }^{138}$

As visitas monitoradas são o meio de divulgação das obras de arte tumulares para o público interessado em geral, através do desenvolvimento de ações educativas que incluem também a iniciativa com professores da rede municipal de

\footnotetext{
${ }^{138}$ O livreto História e arte no Cemitério da Consolação e o guia de visitação estão respectivamente disponíveis em: <http://www.prefeitura.sp.gov.br/portal/a cidade/noticias/index.php?p=25333> e em http://www.prefeitura.sp.gov.br/cidade/upload/cemiterio\%20mapa\%20baixa 1219246518.pdf>.

Acesso em: 15 maio. 2011.
} 
ensino. As ações educativas são realizadas através do programa "São Paulo é uma escola" cujo objetivo é a divulgação nas redes municipais de ensino do potencial e recursos da região central como incentivador das relações comunitárias e de identificação do público com o bairro e com a cidade.

Parece perfeitamente viável o estabelecimento de parcerias com a iniciativa privada e proprietários destas obras, para que ações de divulgação possam ser realizadas, sem que haja nenhum tipo de transtorno em relação à visitação destes espaços, pois algumas das obras que se encontram em edificações particulares apresentam murais interna e externamente.

O circuito englobaria então essa produção mural remanescente dos artistas que pertenceram ao Grupo Santa Helena, com maior ênfase aos trabalhos de Fulvio Pennacchi e Clovis Graciano, que foram os artistas que tiveram maior destaque neste tipo de arte e que apresentam o maior número de obras ainda existentes.

O roteiro poderia ser dividido pela produção das obras de cada artista, por períodos de execução, pela localização das obras, etc, sendo que diferentes opções de rotas para o público poderiam ser criadas.

A arrecadação financeira proveniente do ingresso para visitação do roteiro poderia ter parte revertida para programas de preservação e conservação das obras, já que o restante seria destinado à iniciativa das possíveis empresas patrocinadoras, ou aquelas que executariam o roteiro na cidade de São Paulo. Quanto aos proprietários, incentivos deveriam ser oferecidos como forma de conservarem as suas obras, além de uma assessoria técnica no caso de intervenções a serem realizadas.

Ações semelhantes em parceria com empresas particulares têm sido realizadas pela Associação Viva o Centro nas diversas opções de roteiros culturais no centro de São Paulo.

Verifica-se também o mesmo tipo de iniciativa desenvolvido no exterior com a criação de rotas turísticas inseridas dentro de determinados programas que visem o desenvolvimento sustentável da comunidade local.

A cidade de São Paulo, com um contexto diferente, permite também outros tipos de abordagem que podem garantir o incentivo de ações preservacionistas incluindo a participação da comunidade. 
No mapa a seguir do centro expandido de São Paulo podemos localizar algumas das obras murais existentes na região central e suas proximidades.

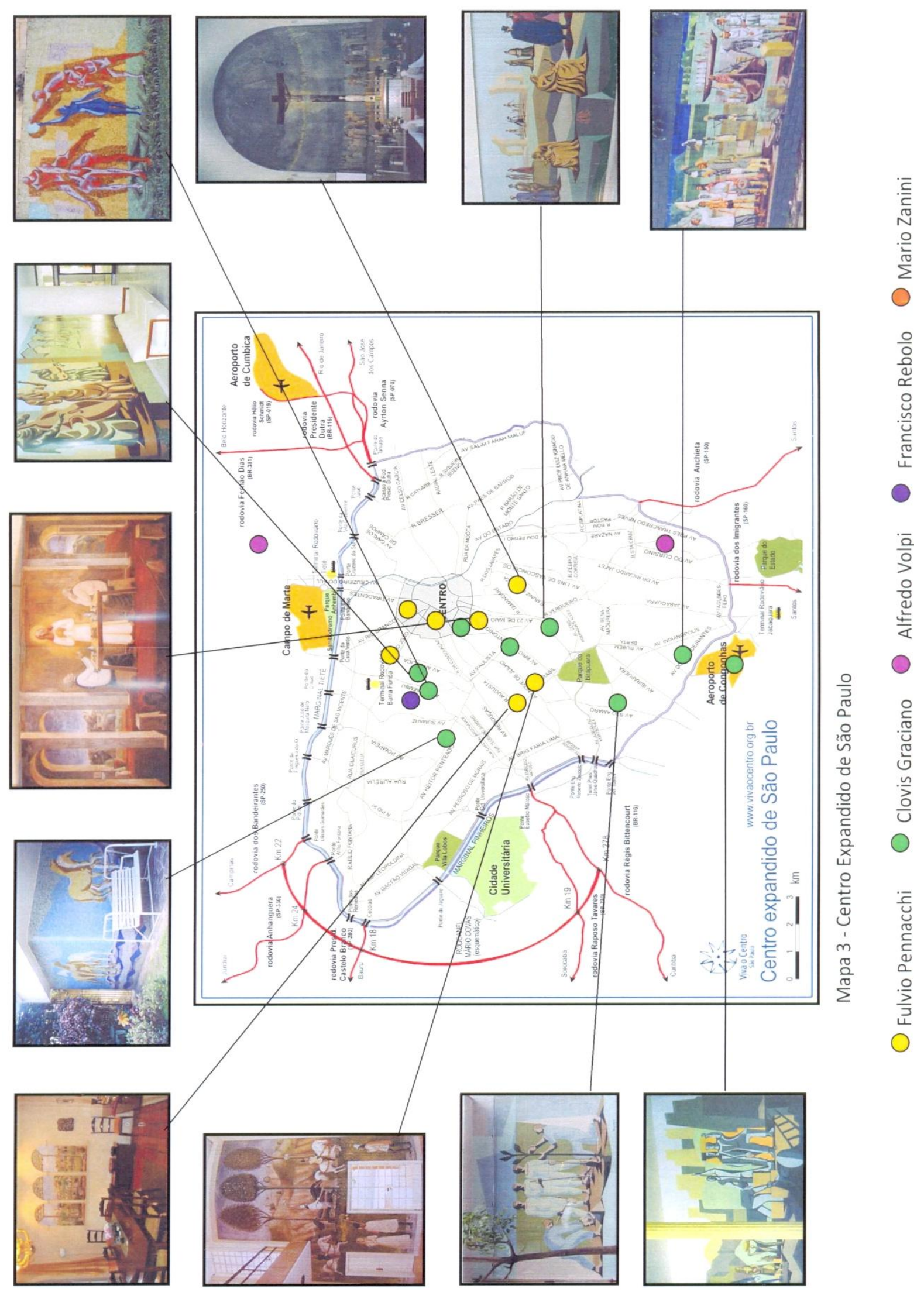




\subsection{Diretrizes}

A partir do estudo realizado nas obras podemos enumerar algumas diretrizes para o estabelecimento de uma ação de preservação. Elas abrangem, na realidade, as idéias já apontadas ao longo do trabalho relativas ao:

1. Inventário.

2. Padronização de registros.

3. Divulgação.

4. Educação patrimonial.

5. Medidas de conservação integrada e preventiva.

6. Monitoramento e gerenciamento da obra.

7. Parceria com universidades para realização de exames laboratoriais.

8. Incentivo a formação profissional.

Apesar dos inúmeros itens a serem considerados, do investimento e do tempo a serem demandados na implantação dos mesmos, verifica-se que, representam ações importantes e que algumas já passaram a ser reconhecidas e implantadas na organização da instituição de preservação na esfera federal.

Além disso, deve-se reconhecer que a organização o planejamento e a administração da preservação constituem passos essenciais de uma política eficiente e que agrega a credibilidade e o reconhecimento dos elementos que fazem parte do processo.

Vencidos os desafios propostos da execução geral do inventário da obras murais e de um banco de dados estruturado para atender as necessidades internas institucionais e, de padronização de registro entre os profissionais, os próximos passos são as ações de divulgação.

Essas ações de divulgação e educação patrimonial são essenciais e devem ser desenvolvidas em conjunto. Embora elas trabalhem com públicos diferenciados, a primeira envolvendo a divulgação com a comunidade em geral e a segunda com o público estudantil, por meio de ações de educação patrimonial em unidades de ensino, o objetivo de ambas é o mesmo, o de obter por parte do público a sensibilização e o reconhecimento do valor cultural da obra. 
Essas ações se estruturadas criarão as bases de medidas que permitam se realizar uma conservação do mural integrada à preservação do bem imóvel, arquitetônico e, a implantação das etapas de monitoramento e gerenciamento da conservação das obras, portanto de uma ação preventiva.

Além deste sistema estabelecido é aconselhável que se articulem e se realizem parcerias com universidades e com institutos de pesquisas para possibilitar um estudo mais aprofundado de determinados agentes de degradação sobre alguns materiais e bens integrados, evitando que o profissional tenha que buscar de forma isolada o contato e arcar com os custos de uma série de exames, sendo que o bem a ser preservado é de interesse e se encontra sob proteção legal de uma ou mais instituições de preservação.

Isso garantiria o acesso aos exames, que deveriam estar entre as exigências a serem estabelecidas pelos órgãos de preservação como parte componente dos relatórios de intervenção. Uma vez facilitada a realização dos exames, não será possível mais utilizar a argumentação das dificuldades, mas caberia ao profissional a responsabilidade pela realização dos mesmos. Sabe-se que algumas instituições já realizam trabalhos de assessoria técnica em suas respectivas áreas de atuação para auxiliar na preservação do patrimônio, mas isso até agora não constituiu uma atividade integrante de toda intervenção de conservação e restauração.

Assim como existem exigências mínimas de documentação e de apresentação de propostas de conservação e restauração para os bens imóveis, poderiam ser determinadas também exigências mínimas relativas à intervenção em bens integrados.

Como componente também dessas diretrizes pode-se mencionar incentivos para a formação profissional na área ou mesmo para o aperfeiçoamento e especialização. 


\section{CONSIDERAÇÕES FINAIS}

Os princípios da moderna teoria da restauração foram sistematizados por Cesare Brandi em 1963 em sua obra "Teoria da Restauração" e tiveram uma repercussão muito grande em diferentes contextos, sendo até hoje utilizados como fundamentos das intervenções de conservação e restauração.

Ao introduzir uma perspectiva filosófica e estética às questões de restauração e ao considerar o reconhecimento da obra de arte como tal, a base para condicionar as práticas de intervenção, Brandi esclarece que esse reconhecimento implica em considerar aspectos relacionados à natureza material e à bipolaridade estético histórica.

A partir da sua definição de restauração fundamentada no reconhecimento da obra de arte como tal, se estabelecem os princípios norteadores das intervenções como a distinguibilidade, a reversibilidade e a mínima intervenção. Os limites da restauração são fornecidos, portanto, segundo ele, pela própria obra considerando a sua unidade potencial. Os conceitos por ele desenvolvidos evidenciam a necessidade de um processo de intervenção crítico que envolve um juízo de valor, retirando, portanto, o caráter empírico dos procedimentos de restauração.

A realização de um inventário geral de obras murais, que corresponde a uma etapa importante para o conhecimento da obra mural, para o conhecimento da produção do artista e como um documento, servirá, portanto, de base e instrumento para estudos posteriores: estilísticos, formais, de história da técnica e da conservação, monitoramento e gerenciamento de planos de conservação.

No estudo aqui realizado foram elencados vários itens que eram determinantes da situação existente na área de conservação e restauração de obras murais e que puderam ser conferidos ao longo do trabalho pelo levantamento e análise realizados.

A prática da preservação na área de murais está condicionada a todos esses aspectos apresentados que constituem a realidade dos profissionais atuantes na preservação do patrimônio.

Apesar das determinações estabelecidas nas respectivas esferas governamentais com relação à documentação exigida e a ser entregue para a realização dos projetos de intervenção de conservação e restauração 
(arquitetônicos), já que para bens móveis e integrados isso não é evidente, podemos concluir que o simples fato de existirem alguns requisitos para a documentação não reflete uma preocupação intensa em se desenvolver uma política mais concisa de preservação, de conservação preventiva nem para a arquitetura nem para os bens integrados.

A necessidade de um modelo básico padronizado de registro documental a ser fornecido para os profissionais de conservação e restauração, de bens imóveis e bens integrados, para desenvolvimento da documentação de seus projetos e relatórios, que posteriormente poderão ser transferidos para o sistema operacional da instituição, minimizará as dificuldades apresentadas em avaliações em função da inexistência de um ou outro item do projeto e/ou do relatório detalhado de intervenções realizadas nas obras. Isso permitirá a uniformização da linguagem e uma avaliação pautada em elementos mais concretos comuns aos projetos e, também o reconhecimento imediato de aspectos necessários e que não tenham sido elaborados. Portanto, tornará mais acessível e compreensível ao técnico da instituição a metodologia de trabalho na área.

O reconhecimento da profissão de conservador-restaurador, se por um lado representa um avanço na área abrindo novas perspectivas, como vagas de trabalho, planos de carreira, etc, também exigirá, dentro em breve, a adoção de algumas medidas que criem uma padronização em relação as atividades executadas, considerando as diferenças de formação dos profissionais.

Alguns profissionais que tiveram só a experiência prática, durante cinco anos, terão a mesma titulação que outros com uma formação teórica-prática obtida em cursos de formação superior reconhecidos. Se muitas das questões aqui levantadas estão relacionadas ao desconhecimento ou incompreensão de fundamentos teóricos e metodológicos, a experiência prática não necessariamente resolverá estes aspectos se não fundamentada em conceitos e teoria.

Conseqüentemente o reconhecimento não implica na imediata elevação do nível de qualificação profissional, mas sim, no fato de que se continua a ter no mercado de trabalho, vários profissionais com formação diversificada. O reconhecimento da profissão eventualmente minimizará a questão da atuação empírica. 
A formação mais específica na área de murais e/ou áreas afins (mosaicos, superfícies arquitetônicas, estuques, etc) permanece como uma lacuna, uma necessidade para que o trabalho não se alterne entre os profissionais da arquitetura e os conservadores-restauradores de pintura, artistas plásticos, ou mesmo pintores de parede.

Diante da configuração do quadro exposto no trabalho sobre a preservação da arte mural e, tendo em vista a inexistência de um documento específico na nossa realidade sobre o tema, bem como da incipiência de um pensamento preservacionista na área, sugere-se que para a estruturação de uma política de conservação preventiva sejam tomadas algumas medidas iniciais que servirão de base para outras a serem posteriormente implantadas.

Entre elas está a execução do inventário, a estruturação de um documento com os conceitos primordiais da área de conservação e restauração de obras murais, a divulgação das obras, etc. Essas necessidades já foram expostas e constatadas neste trabalho.

Considerando que os princípios de conservação e restauração adotados por profissionais especialistas na área estão fundamentados na Teoria da Restauração de Cesare Brandi e que existe um documento específico na área de murais, já elaborado pela comunidade técnica e científica internacional, recomenda-se a adoção dos Princípios do ICOMOS para a Preservação e Conservação-Restauração das Pinturas Murais (2003), ${ }^{139}$ estendido às obras murais e que sejam feitas as devidas complementações ou adaptações necessárias para a realidade local de cada país, como sugeridas no próprio documento.

Os dez artigos nele contidos têm uma grande abrangência em relação ao tema e incluem aspectos não somente relacionados a questões técnicas de execução, mas principalmente relacionados à política de preservação, gerenciamento e comunicação, que são universalmente aplicáveis e que neste caso parecem primordiais para uma atuação efetiva não só dos órgãos de preservação,

\footnotetext{
${ }^{139}$ Os princípios do ICOMOS se referem a pinturas murais, mas poderiam ser estendidos, no caso no nosso contexto, para a arte mural que também engloba o uso de outros materiais. Os princípios estão somente disponíveis na pagina do site do ICOMOS internacional $<$ http://www.international.icomos.org/charters.htm> e não na página do site do ICOMOS $\mathrm{Br}$ $<$ http://www.icomos.org.br/002 002.html>.
} 
mas também dos profissionais envolvidos na prática, dos usuários do espaço e, da comunidade em geral.

Os dez artigos listados na seqüência e, já mencionados anteriormente neste trabalho, são: 1ำ) Política de proteção; 2ำ) Investigação; 3ํำ Documentação; 4ํㅜ) Conservação Preventiva, Manutenção e Gestão de Sítios; 5ํ) Tratamentos de Conservação-Restauração; 6ํㅜ) Medidas de Emergência; 7ํำ Investigação e Informação Pública; 8ํำ Qualificações e Formação Profissional; 9ํํ) Tradições e Renovação; 10ํ) Cooperação Internacional.

A adoção destes princípios, o acréscimo de especificações aplicadas a nossa realidade e a execução de um documento de caráter municipal, estadual e/ou nacional, permitirão que as obras executadas em edificações tombadas passem a ter um tratamento mais homogêneo e padronizado com relação às exigências e a análise de projetos de conservação e restauração para conseqüente execução. Além de estabelecer as exigências de registro e documentação.

Uma vez já elencados no documento os itens a serem considerados cabe apenas o detalhamento e acréscimo de informações relativas a cada um deles, a ser definido pela instituição e/ou por um Grupo de Trabalho de profissionais especialistas da área.

Reconhecemos que, no início, a aplicação deles e a sua validade ficará restrita às obras que se encontram em edificações tombadas e não eliminarão as atividades empíricas executadas fora deste contexto. Isso pode vir a ocorrer num futuro quando todos já estiverem familiarizados com essas exigências. Portanto, o papel dos órgãos de preservação é essencial no estabelecimento destas medidas básicas e na realização de convênios e parcerias com órgãos de ensino e pesquisa, que permitam a realização de exames científicos garantindo um suporte técnico para a caracterização e diagnósticos das obras.

Todavia, outras medidas como a existência de um banco de dados geral das obras murais da cidade de São Paulo, já permitirão que ações preventivas e um monitoramento das obras possam ser implantados evitando que as intervenções passem totalmente despercebidas.

Diferentemente de um bem móvel transportável e fácil de ser apreciado em diferentes lugares e por diferentes pessoas a arte mural deve ser preservada no seu 
local de origem sendo necessário haver interesse comum da sociedade pelo bem, pois é ela que usufrui do espaço onde a obra se insere.

Nesta situação a comunicação e a divulgação destas obras desempenham também um papel significativo. Ações de divulgação permitindo o acesso e o conhecimento da existência dessas obras, bem como as ações de educação patrimonial, de conscientização, sensibilização, identificação e reconhecimento por parte dos usuários dos espaços e da comunidade em relação à obra artística, ou bem cultural, representam importantes instrumentos de preservação.

A realização dessas medidas, acima citadas, já acarretaria em uma contribuição para que ações preventivas pudessem ser gradativamente implantadas, assegurando, através do constante contato com as obras e seus proprietários, a possibilidade de um acompanhamento do seu estado de conservação e do conhecimento de possíveis intervenções a serem feitas, minimizando, assim, a atuação de profissionais não qualificados e a conseqüente descaracterização ou destruição das obras.

Somente nos últimos anos é que surgiu alguma manifestação no sentido de uma reflexão sobre a atuação prática nesta área, ${ }^{140}$ provavelmente em função de uma aproximação maior da universidade com os órgãos de preservação através de consulta ou assessoria técnica e também da articulação estabelecida pelos profissionais na realização de cursos em instituições de ensino superior, vinculados à área de preservação.

Isto tem contribuído para introduzir uma orientação na linha de reflexão sobre a conduta e procedimentos da atuação prática, até então, não questionados pelas respectivas equipes das instituições de preservação, carentes de profissionais especialistas na área.

Porém, um grande percurso neste sentido ainda deve ser feito e talvez se intensifique, a medida que novos profissionais com uma formação mais sólida em instituições reconhecidas e com um currículo específico na área ingressem no mercado.

${ }^{140}$ Um artigo foi escrito e publicado no ultimo congresso da Associação dos Conservadores e Restauradores Brasileiros em junho 2009, avaliando as intervenções anteriores realizadas em 1990 em edificação sob proteção legal do Conpresp. 
Essa ausência de um pensamento preservacionista, de uma linha reflexiva, bem como a carência de profissionais especialistas que atuem na área, contribuiu para que somente na primeira década deste século XXI essa preocupação começasse a aparecer nas instituições.

Isso coincide, como verificado, com a aproximação das áreas de ciências humanas e naturais e com a crescente divulgação e realização de pesquisas de profissionais do campo das ciências e suas respectivas aplicações na preservação de bens culturais.

A ampliação dos meios de comunicação, e a difusão de informações pelos meios eletrônicos (Internet), o freqüente intercâmbio de profissionais especialistas vindos de instituições conceituadas do exterior e vinculados à área de preservação, além de outras informações disponibilizadas pelos profissionais da área com suas experiências, não justificam mais o desconhecimento e a abstenção de quaisquer atitudes e ações na área e relativas ao nosso patrimônio cultural.

Alguns aspectos, também, estão colaborando para a preservação dos murais, como a crescente atuação do DOCOMOMO ${ }^{141}$ e o recente reconhecimento do valor arquitetônico, artístico e cultural de algumas edificações do período da arquitetura moderna, pelo CONPRESP, convergindo para o seu tombamento.

Lembramos que os murais ainda estão presentes na arquitetura contemporânea, com uma linguagem diferente das obras aqui tratadas e, provavelmente, ainda estarão presentes por muito tempo, como produto e reflexo dessa necessidade humana de expressão.

Além disso, é possível perceber a marca de uma evolução temporal deste tipo de arte com uma vertente partindo para uma forma de expressão mais efêmera, a arte de rua, arte urbana, ou grafite. Considerados ou (ainda) não como arte, não se pode deixar de reconhecer que já despertam sobre parte das pessoas um interesse e atração.

São eles que exigirão, dentro em breve, ou mesmo já na atualidade, um modo diferente de pensar a preservação, com novos conceitos e critérios

${ }^{141} \mathrm{O}$ interesse pela preservação da arquitetura moderna vem se consolidando desde a criação do DO.CO.MO.MO em 1988 e inventários tem sido realizados e constituem o instrumento pelo qual o valor é atribuído ao bem cultural e podem se tornar as bases fundamentais da seleção dos bens com fins de preservação. 
preservacionistas, talvez até com questionamentos e posturas que se assemelham as da preservação da arte contemporânea. ${ }^{142}$

Essa nova 'arte', que para muitos historiadores e críticos não pode ser considerada arte ou denominada como tal, tem, sem dúvida, desempenhado certo destaque inserindo a cidade de São Paulo no contexto internacional, como um local representativo dessa forma de expressão 'artística' e, atraindo a atenção da comunidade internacional e da própria municipalidade que passou a reconhecer a sua presença forte no contexto urbano, procurando criar já mecanismos para a sua preservação e colocando novos desafios, que não foram aqui abordados.

Porém, devemos lembrar que antes da inserção da arte de rua, do grafite num circuito de 'galeria a céu aberto' e na organização de um circuito para que possa ser identificada, reconhecida e admirada é necessário que seja lembrada a existência de significativas obras de arte em espaços públicos e também privados que aguardam oportunidade de serem elevadas também a categoria de circuito de arte e que, até agora, ainda não foram reconhecidas pelos órgãos competentes de preservação nem pela população, como parte importante do nosso patrimônio artístico, arquitetônico e cultural.

Apesar da análise ter sido realizada em um local determinado e com um recorte de obras de artistas específicos, acredita-se que pela particularidade e representatividade deste tipo de arte na cidade de SP, como já mencionado, pela quantidade de trabalhos realizados, essa situação seja também comum em outros locais e possível de se configurar como uma realidade geral desta área no país.

$\mathrm{Na}$ análise realizada sobre os aspectos primordiais da estruturação desta prática não foram evidenciadas contradições nos itens problematizados. Confirmouse a hipótese levantada.

Durante o trabalho foram comprovadas as evidências aqui listadas e determinantes da ausência de um pensamento preservacionista na área e de uma linha de atuação prática desvinculada de outros programas de conservação. Além disso, foi constatada a existência de uma prática ainda empírica, reflexo de uma lacuna na formação dos profissionais e da própria ausência de uma estrutura, de

\footnotetext{
${ }^{142}$ Em artigo escrito por Timothy W. Dreschner, em 2003 para o Getty Conservation Institute, GCl é dado destaque para a preservação de murais de comunidade e são levantados aspectos que propõe uma reavaliação ou questionamento de determinadas posturas adotadas na prática tradicional de preservação de murais.
} 
diretrizes ou exigências a serem cumpridas, possivelmente pelo desconhecimento de conceitos e teorias aplicadas a uma área técnica e específica, pelos órgãos de preservação.

Talvez seja possível mencionar aqui algumas palavras proferidas por ocasião de uma entrevista concedida a Jane Slate Siena ${ }^{143}$ do GCl em 1991, em Roma, pela dupla que tanto colaborou no ensino e na prática de conservação e restauração de pinturas murais, Paolo e Laura Mora ${ }^{144}$, a respeito do futuro do trabalho dos conservadores e restauradores, em vinte anos, mais precisamente, portanto, no ano de 2011:

Eu acho que ele nunca será feito pelo computador. Ele sempre envolve uma comunicação física com o objeto. O conservador precisará ser um humanista e um cientista. Eu espero que tenhamos melhor gerenciamento de sítios e estratégias de manutenção para que intervenções cirúrgicas sejam menos freqüentes. (MORA, Laura, 1991, GCI Newsletter 6.1, tradução nossa)

Apesar da existência de certa distância destas idéias da nossa realidade no que concernem as medidas adotadas, ainda espera-se que estas palavras, de profissionais experientes na área, atuando a muitos anos em uma variedade grande de projetos em diferentes partes do mundo sejam um incentivo para que questões aqui abordadas não passem despercebidas e que dentro em breve seja possível se implantar essas medidas preventivas evitando assim que quantias dispendiosas sejam gastas em intervenções 'cirúrgicas' de restauração e evitando, também, a continuidade de uma prática ainda fundamentada no empirismo conforme a hipótese levantada para a realização deste estudo.

\footnotetext{
${ }^{143}$ Jane Slate Siena é chefe das relações institucionais do Getty Conservation Institute.

${ }^{144}$ Chefes dos restauradores do Instituto Central de Restauro em Roma (ICR). "think it will never be done by computer. It will always involve a physical communication with the object. The conservator will need to be a humanist and a scientist. I hope that we will have better site management and maintenance strategies so that surgical interventions are less frequent." (MORA, Laura,1991,GCI newsletter 6.1)
} 


\section{REFERÊNCIAS BIBLIOGRÁFICAS:}

AMARAL, Aracy. Arte e meio artístico: entre a feijoada e o x-burguer (19611981). São Paulo, Nobel, 1983.

Arte para quê? A preocupação social na arte Brasileira 1930-1970. São Paulo, Studio Nobel, 2003.

ANDALORO, Maria, A cura di. La Teoria del Restauro nel Novecento da Riegl a Brandi. Atti Del convegno Internazionale di Studi (Viterbo, 12-15 novembre 2003). Universitá degli studi della Tuscia, Fondazione Carivit di Viterbo. Firenze, Nardine Editore, 2006.

ANDRADE, Mário. Ensaio sobre Clóvis Graciano. São Paulo, 1944.

ANDRADE, Antonio Luis Dias de, Um estado completo que jamais pode ter existido. São Paulo, tese de Doutorado FAU USP, 1993.

ANTUNES, Fatima M.R. F., PASSOS, Maria Lúcia P. Obras de arte em Logradouros públicos do município de São Paulo: a atuação do DPH na gestão do patrimônio cultural paulistano. Revista do Arquivo Municipal no 204. 30 Anos de DPH - Departamento do Patrimônio Histórico da cidade de São Paulo. São Paulo, DPH/PMSP, 2006, p.139-149.

ARANTES, Antônio Augusto. Documentos históricos, documentos de cultura. In: Revista do Patrimônio Histórico e Artístico Nacional, oㅡ 22. Brasília, IPHAN, 1987, p. 48-55.

ARAÚJJO, Olívio Tavares de. Rebolo. Editora K MWM. São Paulo, 1986.

Arbeitshefte zur Denkmalpflege in Niedersachen 11. Forschungsprojekt Wandmalerei-Schäden. Niedersachsen Landesverwaltungsamt - Institut für Denkmalpflege. Hannover, 1994.

ARENDT, Claus. The Role of Architectural fabric in the preservation of wall paintings. In: Conservation of Wall Paintings, Proceedings of a symposium. London, Courtauld Institute of Art, Getty Conservation Institute, 1987, p.29-41.

ARGAN, Giulio Carlo. História da arte como história da cidade. São Paulo, Martins Fontes, 1995.

BAFFI, Mirthes I. S. O IGEPAC-SP e outros inventários da Divisão de preservação do DPH: um Balanço. 30 Anos de DPH - Departamento do Patrimônio Histórico da cidade de São Paulo. Revista do Arquivo Municipal no 204. 30 Anos de DPH - Departamento do Patrimônio Histórico da cidade de São Paulo. São Paulo, DPH/PMSP, 2006, p.169-191.

BARDI, P. M. Fulvio Pennacchi. São Paulo, Raízes, 1980. 
BASILE, Giuseppe a cura di. CESARE BRANDI OGGI PRIME RICOGNIZIONI Atti Del Convegno. Comitato Nazionale per le celebrazione e le iniziative culturali per il centenario della nascita di cesare Brandi (8 aprile 1906 - 19 gennaio 1988).Saonara, II Prato, 2008.

Il pensiero di Cesare Brandi dalla teoria alla pratica Cesare Brandi thought from theory to practice. Atti dei seminari di: München; Hildesheim; Valencia; Lisboa; London; Warszawa; Bruxeles; Paris. / ed. by Giuseppe Basile . Saonara, II Prato Editore 2008.

BELL, Doroty. The influence of Cesare Brandi's Teoria in the United Kingdoms. In: Cesare Brandi oggi prime ricognizioni. BASILE, Giuseppe a cura di. Atti Del Convegno. Comitato Nazionale per le celebrazione e le iniziative culturali per il centenario della nascita di cesare Brandi (8 aprile 1906 - 19 gennaio 1988). Roma, ICR, 2008, p. 155-159.

BELLUZZO, Ana Maria de M. Arte Artesanato e Industria. Tese (Doutorado), FAUUSP. São Paulo, 1988.

BOITO,Camilo. Os Restauradores. Trad. Beatriz M. Kühl e Paulo M. Kühl. São Paulo, Ateliê Editorial, 2002.

BOMFORD, David. Issues in Conservation of Painting. In: Historical and Philosophical Issues in the Conservation of Cultural Heritage. Edited by Nicholas Stanley Price, M. Kirby Talley, Jr., Alessandra Melucco Vaccaro. Los Angeles, Getty Conservation Institute, 1996.

BRANDI, Cesare. Teoria da Restauração. Trad. Beatriz M. Kühl. São Paulo, Ateliê Editorial, 2004.

BRILL, Alice. Mário Zanini e seu tempo: do Grupo Santa Helena às bienais.

São Paulo, Perspectiva, 1984.

BRUAND, Yves. Trad. Ana M. Goldberger. Arquitetura Contemporânea no Brasil. São Paulo, Perspectiva, 4르ed., 2008.

BURY, John. Arquitetura e Arte no Brasil Colonial. Myrian Andrade Ribeiro de Oliveira (org.). Brasília, DF, IPHAN/MONUMENTA, 2006.

Cadernos do IGEPAC-SP 1 aspectos metodológicos. Leila Regina Diêgoli, coord., et al. Inventário Geral do Patrimônio Ambiental e Cultural: metodologia. São Paulo, Prefeitura Municipal, Secretaria Municipal de Cultura, 1986.

CARBONARA, Giovanni. Avvicinamento al Restauro, teoria, storia monumenti. Napoli, Liguori Editore, 1997.

The Integration of the image problems in the Restoration of Monuments. Nicholas Stanley Price, M. K. Talley, Jr. e A. Melucco Vaccaro, (eds). Los Angeles, The J. Paul Getty Trust, 1996, p. 236-243. 
Trattato di Restauro Architettonico; secondo aggiornamento: grandi temi di restauro. Torino, UTET, 2008, vol. 9 e 10.

CARPINETTI, Luiz C. R., MIGUEL, Paulo, GEROLAMO, Mateus C. Gestão da Qualidade ISO 9001:2008 Princípios e Requisitos. São Paulo, Editora Atlas, 2009.

CAVALCANTI, Lauro. Moderno e Brasileiro, A história de uma nova linguagem na arquitetura (1930-1960). Rio de Janeiro, Jorge Zahar, 2006.

CENNI, Franco. Italianos no Brasil "andiamo in América". São Paulo: Editora Martins, Editora da Universidade de São Paulo, 1975.

CHIARI, Giacomo e LEONA, Marco. The State of Conservation Science. In: The Getty Conservation Institut Newsletter, vol. 20 № 2. Los Angeles, GCl, 2005, p. 6.

CATHER, Sharon - Workshop Novos avanços nas técnicas de Conservação/Restauração de Pinturas Murais - 7 a 8 de agosto 2000 - Centro Brasileiro Britânico. São Paulo, 2000.

COLALUCCI, Gianluigi. Validità della Teoria di Cesare Brandi. In: Il pensiero di Cesare Brandi dalla teoria alla pratica. Cesare Brandi thought from theory to practice. Atti dei seminari di: Muenchen; Hildesheim; Valencia; Lisboa; London; Warszawa; Bruxeles; Paris / ed. by Giuseppe Basile . Saonara, II Prato Editore 2008, p. 93-104.

Computação gráfica: pesquisas e projetos rumo à Educação Patrimonial. Seminário 4 a 6 de novembro de 2008. São Paulo, PMSP / SMC / DPH / Arquivo Histórico Municipal Washington Luís AHMWL, 2008. Disponível em: $<$ http://www.arquiamigos.org.br/seminario3d/>. Acesso em: 04 mai. 2010.

CONSERVACIÓN DEL PATRIMONIO: Orientaciones de las Escuelas de Arquitectura em América Latina. Série: Red Alvar Patrimonio y Proyecto. Firenze, Alinea Editrice, 2006, p.309.

CORBUSIER, Le. A arquitetura e as Belas-Artes. In: Revista do Patrimônio Histórico e Artístico Nacional, n. 19. Brasília, IPHAN, 1984, p.53.

COSTA, Lúcio. Razões da Nova arquitetura, In Arte em Revista, ano 2, n. 34. Brasília, IPHAN, 1980, p.15.

.A Crise da Arte Contemporânea, In Brasil - Arquitetura

Contemporânea n. 1, ago-set., 1953, p. 2.

COSTA, Lygia Martins. A defesa do Patrimônio Cultural Móvel. In: Revista do Patrimônio Histórico e Artístico Nacional. Brasília,IPHAN, no 22, 1987, p. 145- 153.

DARDES, Kathleen e LEVIN, Jeffrey. Preventive Conservation a Discussion. In: The Getty Conservation Institute Newsletter, vol.15, № 2. Los Angeles, GCl, 2000, p.10-13. 
DARDES, Kathleen e DRUZIK, James. Managing the environment an update on Preventive Conservation. In: The Getty Conservation Institute Newsletter, vol.15, no 2. Los Angeles, GCl, 2000, p. 4-9.

DARDES, Kathleen. Recent developments in preventive conservation in the United States In: Anais do VII Seminário Panorama Atual da Conservação na America Latina Petrópolis: ABRACOR, 1994.

DE LA TORRE, Marta, MASON, Randall. Values and Heritage Conservation. Los Angeles, The Getty Conservation Institute, 2000.

DURAND, José Carlos. Arte Privilégio e Distinção, Artes Plásticas, Arquitetura e Classe Dirigente no Brasil, 1855/1985. São Paulo: Editora Perspectiva, Coleção Sociologia da Arte, 1989.

EPPICH, Rand, LEBLAN, François. Documenting our Past for the Future. In: The Getty Conservation Institute Newsletter, vol. 20, ำ 3, 2005, p. 5-9

FONSECA, Maria Cecília Londres. O patrimônio em processo trajetória da política federal de preservação no Brasil, 2a ed. Rio de Janeiro: Ed. da UFRJ, IPHAN, 2005.

FURTADO, Fátima.O processo de Monitoramento, Avaliação e Controle de

Projetos. In: Gestão do Patrimônio Cultural Integrado. Recife, Ed. Universitária da UFPE, 2002, p. 163-168.

GITAHY, Celso. O que é graffiti. São Paulo, Editora Brasiliense, 1999.

GONÇALVES, Antonio (org.), GONÇALVES, Lisbeth Rebollo (org.). Rebolo: 100 anos. São Paulo, Edusp: Imprensa Oficial do Estado, 2002.

GONÇALVES, Cristiane Souza. Restauração Arquitetônica - A experiência do Sphan em São Paulo 1937-1975. São Paulo, Annablume, Fapesp, 2007.

GraDoc (Graphic Documentation Systems in Mural Painting Conservation). SCHMID, W. (ed.). Research Seminar16-20 November 1999. Rome, ICCROM, 2000.

GUIDO, Maria Christina. Portinari segundo Mário.In: Revista do Patrimônio vol. 20, Histórico. São Paulo, IPHAN, 1944, p 64-66.

GUICHEN, Gaël e NARDI, Roberto. Mosaic Conservation: Fifty Years of Modern Practice. In: Getty Conservation Institute Newsletters vol. 21, 1. Los Angeles, GCI, 2006.

HERITAGE, Adrian. Challenges and Advances in Training. In: The Getty Conservation Institute Newsletters, vol. 25 no 2. Los Angeles, GCl, 2010, p. 10-11.

ICCROM. Anotações de aula. Curso MPC 98 - Mural Painting Conservation. Roma, ICCROM, 1998. 
ICOM-Committee for Conservation 13th Triennial Meeting. Preprints volume I. Preventive Conservation. Rio de Janeiro, 2002.

ICOMOS. Principles for the Preservation and Conservation-Restoration of Wall Paintings (2003). Disponível em:

$<$ http://www.international.icomos.org/charters/wallpaintings_e.htm>. Acesso em: 04 out. 2006.

ICOMOS. Charters and other Doutrinal texts. Disponível em: < http://www.international.icomos.org/charters.htm>. Acesso em: 22 jun. 2007.

IDEAS Investigations into Devices against Environmental Attack on Stones. GKSS Forschungszentrum Geesthacht GmbH.Geesthacht. Germany, 1994.

JOKILEHTO, Jukka. A History of Architectural Conservation. Oxford, ButterworthHeinemann, 2002.

KOLLER, Manfred. Learning from the history of preventive conservation. In: Preprints of the Contribution to the Ottawa Congress 12-16 september 1994. Preventive Conservation: practice, theory and research. London: International Institut for Conservation of historic and artistic Works, 1994.

KÜHL, Beatriz Mugayar. História e Ética na Conservação e na Restauração de Monumentos Históricos. Disponível em: $<$ http://www.revistasusp.sibi.usp.br/pdf/cpc/n1/a03n1.pdf>. Acesso em: 20 ago. 2007.

Cesari Brandi e a Teoria da Restauração. In: Revista da pós-graduação FAU/USP, no 21. São Paulo, 2007, p.198-243.

LASMAC - 10 Simpósio Latino Americano sobre Métodos Físicos e Químicos em Arqueologia, Arte e Conservação do Patrimônio Cultural dias 11 a 16 junho de 2007. São Paulo, 2007.

LEGÉR, Fernand. Funções da Pintura. São Paulo, Nobel, 1989.

LEMOS, Carlos A. C. Azulejos Decorados na Modernidade Arquitetônica Brasileira. In: Revista do Patrimônio Histórico e Artístico Nacional, ㄲo 20. Brasília, IPHAN, 1984, p. 167-174.

LOURENÇO, Maria Cecília França. Operários da modernidade. São Paulo, Hucitec, Edusp, 1995.

LUXEN, Jean-Louis. Reflections on the use of Heritage Charters and Conventions. In: The Getty Conservation Institute Newsletter, vol. 19 nํ 2. Los Angeles, GCl, 2004, p. 4-9.

LUXEN, Jean-Louis. A Discussion about Heritage Charters and Conventions. In: The Getty Conservation Institute Newsletter, vol. 19 № 2. Los Angeles, GCl, 2004, p. 10-15. 
MARIJNISSEN, R.H. Degradation, Conservation, and Restoration of Works of Art: Historical Overview. In:Historical and Philosophical issues in the Conservation of Cultural Heritage. Nicholas Stanley Price, M. K. Talley, Jr. e A. Melucco Vaccaro, (eds). Los Angeles, The J. Paul Getty Trust, 1996, p. 275-279.

MENDES, Marylka, BAPTISTA, Antonio Carlos N. (org.). Restauração Ciência e Arte. 3.ed. Rio de Janeiro, Editora UFRJ/IPHAN, 2005.

MELLO, Carlos H. P., SILVA, Carlos E. S. da, TURRIONI, João Batista, SOUZA, Luiz G. M. de. ISO 9001:2008 Sistema de Gestão da Qualidade para operações de produção e serviços. São Paulo, Editora Atlas, 2009.

MICELI, Sérgio. SPHAN: refrigério da cultura oficial. In: Revista do Patrimônio Histórico e Artístico Nacional, № 22. Rio de Janeiro, 1987.

MORA, Laura \& Paolo, PHILLIPOT, Paul. Conservation of Wall Paintings. London, Butterworths, 1984.

MORA, Paolo, MORA, Laura S.,PHILIPPOT, Paul. Problems of presentation. In: Historical and Philosophical issues in the Conservation of Cultural Heritage. Nicholas Stanley Price, M. K. Talley, Jr. e A. Melucco Vaccaro, (eds). Los Angeles, The J. Paul Getty Trust 1996, p. 343-354.

MORAES, Julio Correa Dias de. Pintura Mural no Brasil - o Início da redescoberta. In: Revista da Biblioteca Mário de Andrade № 52. São Paulo, Secretaria Municipal de Cultura, 1994.

PECCINNI, Daisy Valle Machado (Apresentação de). GRUPO Seibi - Grupo do Santa Helena: década 35-45. São Paulo, FAAP, 1988.

PEDROSA, Mario. Amaral, Aracy org. Mundo, Homem, Arte em Crise. São Paulo, Editora Perspectiva, 1986. (Coleção Debates Arte).

Amaral, Aracy org. Dos Murais de Portinari aos Espaços de Brasília. São Paulo, Editora Perspectiva, 1981. (Coleção Debates, Crítica).

EDUSP, 1998.

Arantes, Otília org. Acadêmicos e Modernos. São Paulo,

PENNACHI, Valério Antonio. Pennachi Pintura Mural. São Paulo, Metalivros, 2002.

PENNACCHI 100 anos. Catálogo da Exposição retrospectiva de Fulvio Pennacchi. São Paulo, Secretaria do Estado da Cultura, Pinacoteca do Estado, 2006.

PESSOA, José Org. Lúcio Costa: Documentos de trabalho. Rio de Janeiro, IPHAN, 2004. 
PHILIPPOT, Paul. Restoration from the perspective of Humanities. Historical and Philosophical issues in the Conservation of Cultural Heritage. Nicholas Stanley Price, M. K. Talley, Jr. e A. Melucco Vaccaro, (eds). Los Angeles, The J. Paul Getty Trust, 1996, p. 216-229.

.Historic Preservation: Philosophy, Criteria, Guidelines, I. Historical and Philosophical issues in the Conservation of Cultural Heritage. Nicholas Stanley Price, M. K. Talley, Jr. e A. Melucco Vaccaro, (eds). Los Angeles, The J. Paul Getty Trust, 1996, p. 268-274.

.Historic Preservation: Philosophy, Criteria, Guidelines, II. Historical and Philosophical issues in the Conservation of Cultural Heritage. Nicholas Stanley Price, M. K. Talley, Jr. e A. Melucco Vaccaro, (eds). Los Angeles, The J. Paul Getty Trust, 1996, p. 358-363.

PIQUÉ, Francesca. Science for the Conservation of Wall Paintings. In: The Getty Conservation Institute Newsletter, vol. 20 n 2. Los Angeles, 2005, p. 21-24.

RAMOS FILHO, Orlando. Restauração de Bens Móveis e Integrados: 40 anos. In: Revista do Patrimônio Histórico e Artístico Nacional nํ⒉ Brasília, 1987, p. 154162.

RAINER Leslie. The Conservation of Decorated Architectural Surfaces: Some Perspectives. In: The Getty Conservation Institute Newsletters, vol. 25 no 2 . Los Angeles, GCl, 2010, p. 5-10.

REIS FILHO, Nestor Goulart. Quadro da arquitetura no Brasil. São Paulo, Perspectiva, 1970.

RIEGL, Alois. The Modern Cult of Monuments: Its Essence and Its Development. In: Historical and Philosophical issues in the Conservation of Cultural Heritage. Nicholas Stanley Price, M. K. Talley, Jr. e A. Melucco Vaccaro, (eds). Los Angeles, The J. Paul Getty Trust, 1996, p. 69-83.

RODRIGUES, Marly. Imagens do passado a instituição do patrimônio em São Paulo, 1969-1987. São Paulo, Ed. UNESP, IMESP, CONDEPHAAT, FAPESP, 2000.

ROY, Ashok e SMITH, Perry .(Orgs). Preprints of the Contribuition to the Ottawa Congress 12-16 septmber 1994. Preventive Conservation: practice, theory and research. London, International Institute for Conservation of Historic and Artistic Works, 1994.

RUSKIN, John. A Lâmpada da Memória. Trad. Maria Lucia B. Pinheiro. São Paulo, Ateliê Editorial, 2008.

SCHMID, Werner, ADDISON, Alonzo, BRYAN, Paul. People and Technology a discussion about Heritage Documentation. In: The Getty Conservation Institute Newsletter, vol. 20, no 3. Los Angeles, GCl, 2005, p. 10-16. 
SIENA, Jane Slate. From the Heart: A Conversation with Paolo and Laura Mora. In: The Future of Conservation, The Getty Conservation Institute Newsletter, Vol. 6.1. Los Angeles, GCI, 1991.

SOUZA, Luiz Antonio Cruz. A Importância da Conservação Preventiva. In Revista da Biblioteca Mário de Andrade v.52. São Paulo, 1994.

STAUB, Ursula Schaedler. Le influenze di Cesare Brandi e dell' Istituto Centrale per II Restauro sulla teoria e sulla prassi del restauro in Germania. In: Cesare Brandi oggi prime ricognizioni. BASILE, Giuseppe a cura di. Atti Del Convegno. Comitato Nazionale per le celebrazione e le iniziative culturali per il centenario della nascita di cesare Brandi (8 aprile 1906 - 19 gennaio 1988). Roma, ICR, 2008, p. 160-169.

STOVEL, Herb. Monitoramento para gerenciamento e conservação do

Patrimônio Cultural. In: Gestão do Patrimônio Cultural Integrado. Recife, Ed.

Universitária da UFPE, 2002, p. 175-185.

TIRELLO, Regina A, PINHEIRO, Maria Lucia Bressan (org.). O CPC-USP. Reuniões Técnicas: Ciências aplicadas e a conservação de bens culturais. São Paulo, CPC-USP, 2007.

TIRELLO, Regina A. Restauro de um mural moderno na USP, O Afresco de Carlos Magano. (org) Comissão de Patrimônio Cultural - CPC/USP. São Paulo, 2001.

A ruína, o restauro e as pinturas murais oitocentistas do Vale do Paraíba Paulista. São Paulo, FAU/USP 2v. Tese de doutorado, 1999.

VERGUEIRO, Maria Thereza. Graciano, o Homem a Arte. São Paulo, FAU/USP, s/d.

VIOLLET LE DUC, Eugène Emmanuel. Restauração. Trad. Beatriz M. Kühl. São Paulo, Ateliê Editorial, 2000.

VIÑAS, Salvador Muñoz. Contemporary Theory of Conservation. London, Elsevier Butterworth-Heinemann, 2005.

.Pertinencia de la Teoria del Restauro. In: II pensiero di Cesare Brandi dalla teoria alla pratica. Cesare Brandi thought from theory to practice. Atti dei seminari di: Muenchen; Hildesheim; Valencia; Lisboa; London; Warszawa; Bruxeles; Paris. II prato editore - Associazione Giovanni Secco Suardo. Saonara : II Prato editore, 2008, p. 115-118.

Christabel Blackman. Disponível em:

New Horizons for Conservation Thinking. Interview by $<$ http://www.e-conservationline.com/content/view/627/195/>. Acesso em: 20 dez. 2010.

WILHELM, Vera Regina Barbuy. A Arte Mural do Grupo Santa Helena, um estudo para preservação. Dissertação de Mestrado, FAU/USP. São Paulo, 2006. 
WOLFF, Silvia Ferreira Santos. Jardim América. 0 primeiro bairro-jardim de São Paulo e sua arquitetura. Tese de doutoramento, FAU/USP. São Paulo, 1998.

WONG, Lorinda. From Silk Road to Digital Domain, Managing Information for a Wall Painting Conservation Project. In: The Getty Conservation Institute Newsletter, vol. 20, no 3. Los Angeles, GCl, 2005, p. 21-24.

ZANINI, Walter, org. História geral da arte no Brasil. Apresentação de Walther Moreira Salles. São Paulo, Instituto Walther Moreira Salles, Fundação Djalma Guimarães, 1983. v.1 e 2.

A arte no Brasil nas décadas de 1930-40: o Grupo Santa Helena. São Paulo, Nobel, EDUSP, 1991.

ZANINI, Walter, ALBUQUERQUE, Marília Saboya de. O Grupo Santa Helena. São Paulo, Catálogo de exposição MAM, 1995.

ZEHNDER, K. Naturwissenschaftliche Untersuchung und Dokumentation des Materiellen Zerfalls an Denkmälern - Hinweise zum praktischen Vorgehen Beispiele - Salzschäden an Wandmalereien. München, Arbeithefte des Bayerischen Landesamtes für Denkmalpflege. 1996, p. 29-33.

\section{PERIÓDICOS:}

The Getty Conservation Institute Newsletter, vol. 19 n²/2004; vol. 20 nำ 2/2005; vol. $20 n^{\circ}$ 3/2005.

Anais dos Congressos da ABRACOR, Associação Brasileira de Conservadores Restauradores de Bens Culturais.

ARC Revista Brasileira de Arqueometria, Restauração e Conservação. Recife, AERPA Editora.

Getty Conservation Institute (GCI) Newsletter.

ICOMOS Newsletter.

Revista CPC USP 


\section{WEBSITE:}

http://www.aber.org.br

http://www.abnt.org.br

http://www.abracor.com.br

http://www.cci-icc.gc.ca

http://www.cultura.sp.gov.br/portal

http://www.english-heritage.org.uk

http://www.faop.mg.gov.br/?action=interna\&sec=4\&cat=4\&con=20

http://www.fapesp.br/publicacoes/rebolo

http://www.forumpatrimonio.com.br

http://www.getty.edu

http://www.iccrom.org

http://www.icomos.org

http://www.icr.beniculturali.it

http://www.iphan.org.br

http://www.iscr.beniculturali.it

http://www.itaucultural.org.br

http://www.macvirtual.usp.br

http://www.monumenta.gov.br

http://www.mosaicosdobrasil.tripod.com

http://www.opificiodellepietredure.it

http://www.palimpsest.stanford.edu

http://www.patrimoniocultural.org

http://www.portinari.org.br

http://www.prefeitura.sp.gov.br

http://www.prefeitura.sp.gov.br/cidade/secretarias/cultura/conpresp/

http://www.prefeitura.sp.gov.br/cidade/secretarias/cultura/patrimonio historico/

http://www.restaurabr.org

http://www.sbf1.sbfisica.org.br/eventos/extras/lasmac/

http://www.ufrgs.br

http://www.uol.com.br/franciscorebolo

http://www.vitruvius.com.br

http://www.villafarnesina.it 
ANEXOS:

Anexo I Questionário de entrevista.

Anexo II Princípios do ICOMOS para a Preservação e Conservação Restauração das Pinturas Murais (2003)

Anexo III Código De Ética Do Conservador-Restaurador (2005) 
Anexo I

Questionário para pesquisa 


\section{ARTE MURAL}

EMPRESA:

RESPONSÁVEL:

CARGO:

ENDEREÇO:

TELEFONE:

FAX:

EMAIL:

QUESTIONÁRIO PREENCHIDO EM:

QUESTIONÁRIO PREENCHIDO POR:

ENTREVISTA EM:

ENTREVISTADO:

CARGO: 


\section{ARTE MURAL}

MEMBROS

1970-1980 $\quad 1980-1990 \quad 1990-2000 \quad 2000-2010$

DA EQUIPE EM N:

ARQUITETO

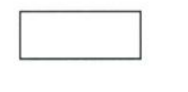

COORD./RESTAURADOR
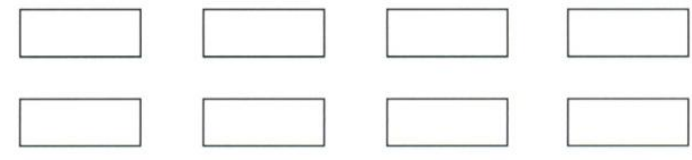

RESTAURADOR
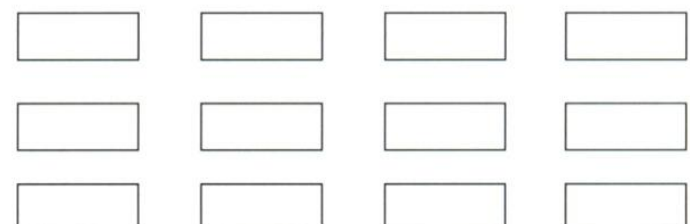

ESTAGIÁRIO

AUXILIAR/APRENDIZ
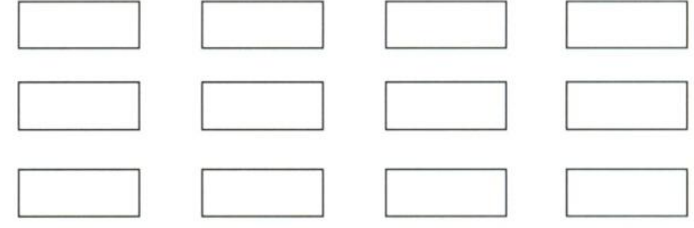

PINTOR

PEDREIRO
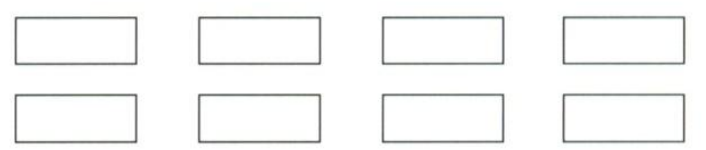

ESCULTOR

ARTISTA PLÁSTICO
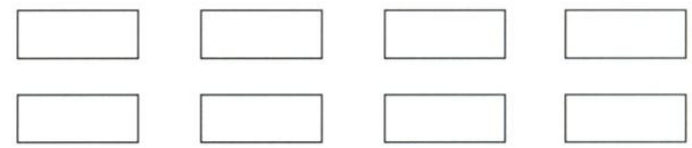

FORMAÇÃO - QUANTOS FUNCIONÁRIOS TINHAM: ( marcar número)

$1970-1980 \quad 1980-1990 \quad 1990-2000 \quad 2000-2010$

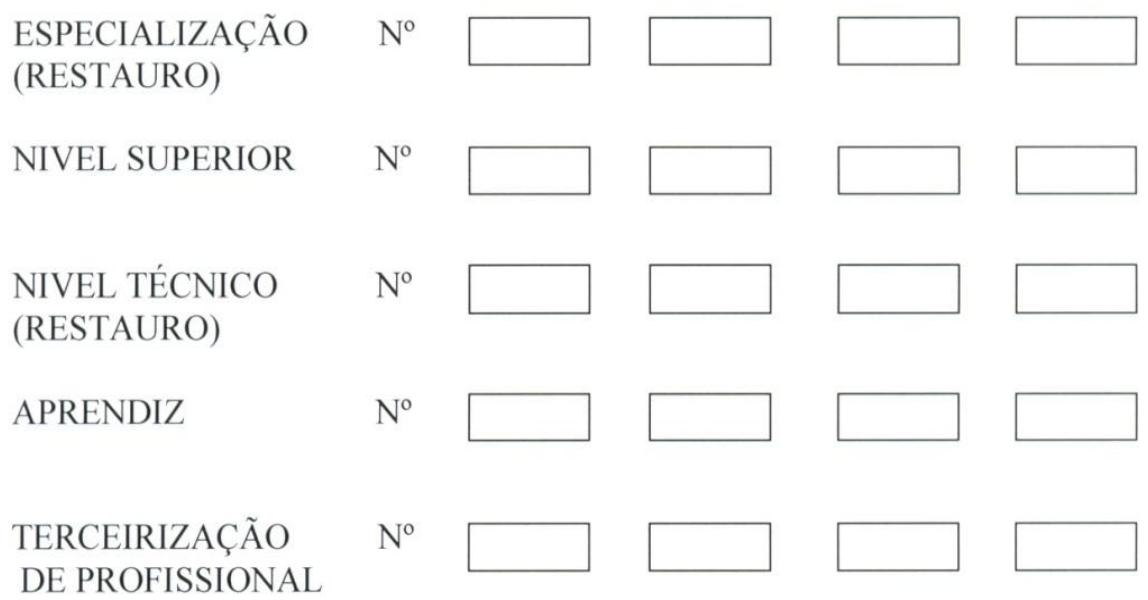




\section{ARTE MURAL}

TRABALHOS REALIZADOS EM: ( marcar $\mathbf{x}$ )

1970-1980

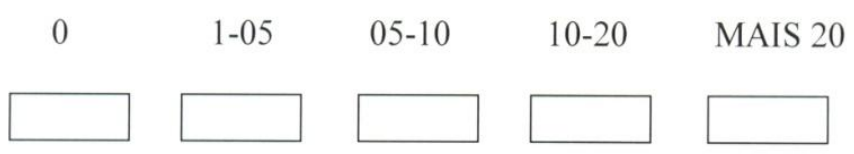

1980-1990

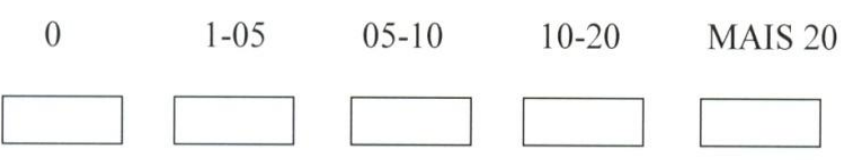

1990-2000

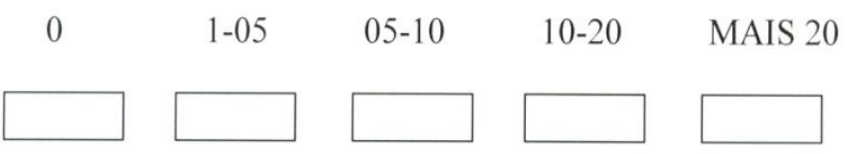

2000-2010

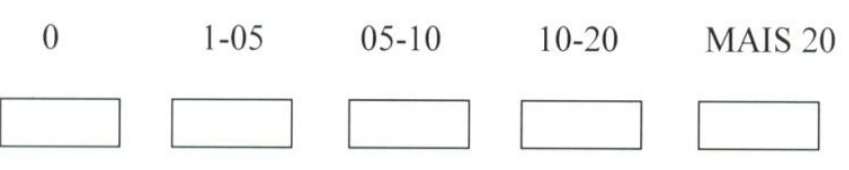

EXECUÇÃO DE TRABALHO PARA: (marcar $n^{\circ}$ de trabalhos)

$1970-1980 \quad 1980-1990 \quad 1990-2000 \quad 2000-2010$
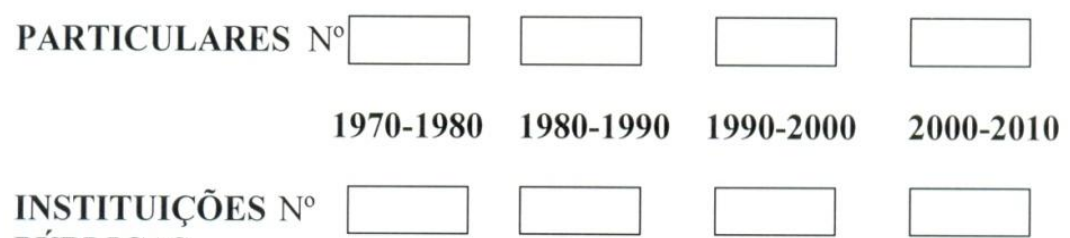

PÚBLICAS

$1970-1980 \quad 1980-1990 \quad 1990-2000 \quad 2000-2010$

INSTITUIÇÕES N ${ }^{\circ}$

PRIVADAS

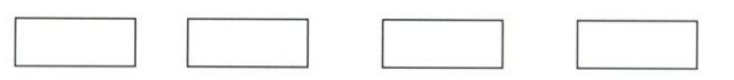




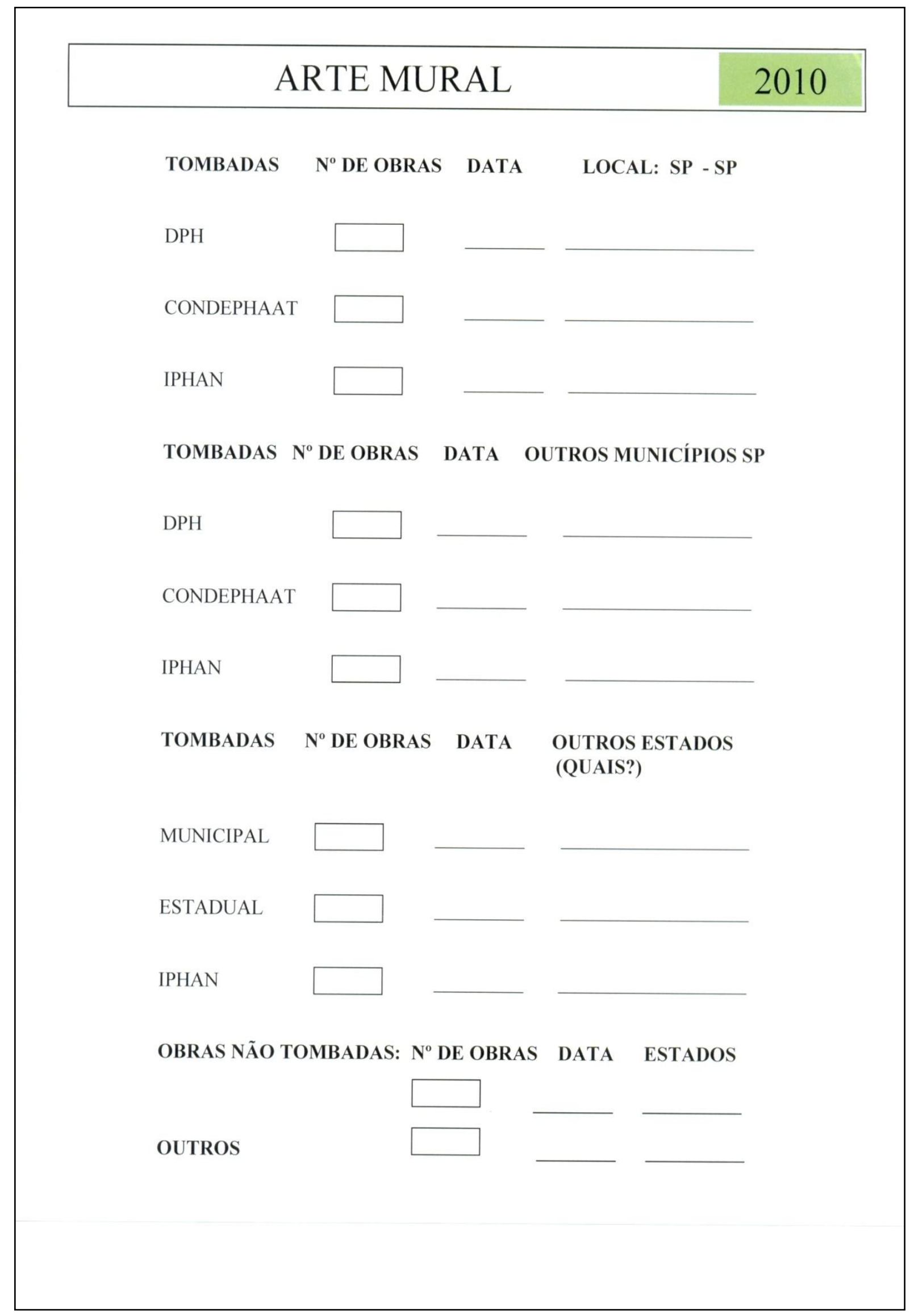


ÁREAS DE ATUAÇÃO:

DIFICULDADES ENCONTRADAS:

TIPOS DE PROBLEMAS:

ESTRUTURAL SUPORTE CAMADA PICTÓRICA

1970-1980
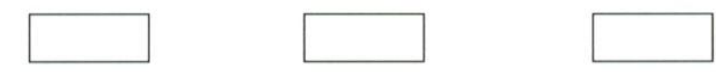

1980-1990
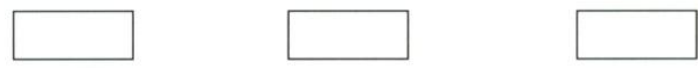

1990-2000
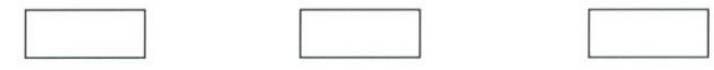

2000-2010
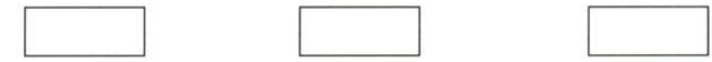

OUTROS: 


\section{ARTE MURAL}

LOCALIZAÇÃO DAS OBRAS: (marcar número de obras)

$1970-1980 \quad 1980-1990 \quad 1990-2000 \quad 2000-2010$

NACIONAL
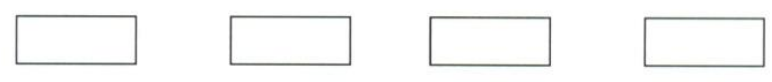

ESTADUAL
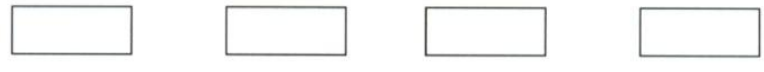

MUNICIPAL
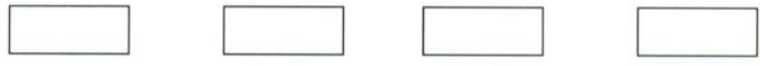

OBTEVE MATERIAL SOBRE A OBRA TRABALHADA: (marcar $x$ ) $1970-1980 \quad 1980-1990 \quad 1990-2000 \quad 2000-2010$

PLANTAS
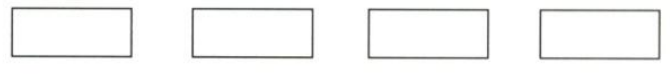

PROJETOS/DESENHOS
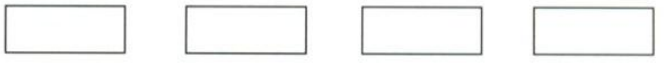

FOTOGRAFIAS
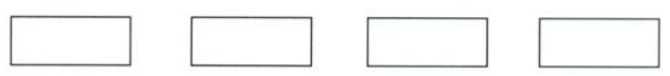

TEXTOS
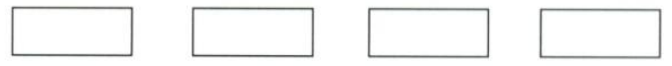

FONTES ORAIS
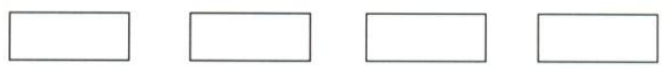

DEPOIMENTOS

DO ARTISTA
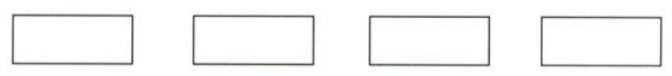

E DE FAMILIARES

BIBLIOGRAFIA
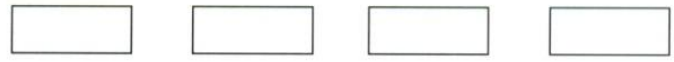

RELATÓRIOS

ANOTAÇÕES
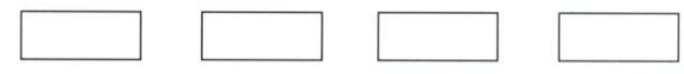


\section{ARTE MURAL}

COM QUEM OBTEVE MATERIAL SOBRE A OBRA

TRABALHADA: (marcar $\mathrm{x}$ )

$1970-1980 \quad 1980-1990 \quad 1990-2000 \quad 2000-2010$

ARTISTA
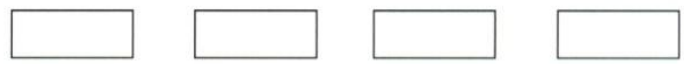

NO LOCAL DA OBRA
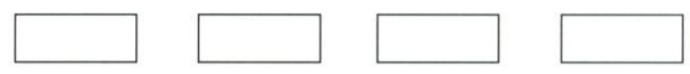

AMIGOS DO ARTISTA
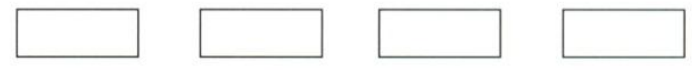

FUNCIONÁRIOS

DO LOCAL
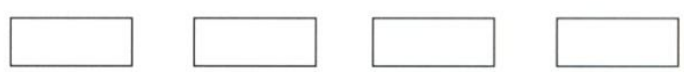

FONTES ORAIS

DEPOIMENTOS

DE FAMILIARES
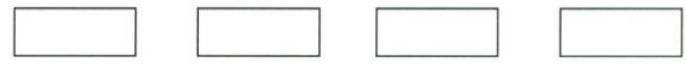

ARQUITETO DA

OBRA
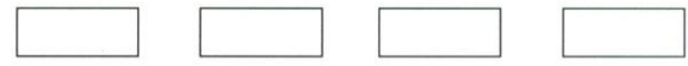

D.P.H.
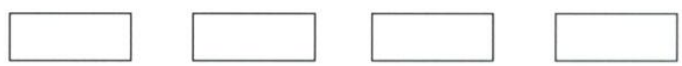

CONDEPHAAT
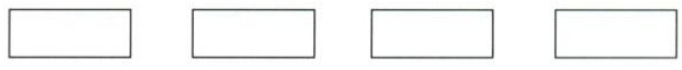

IPHAN
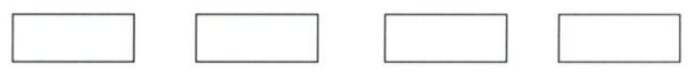

OUTROS: 


\section{ARTE MURAL}

DECISÕES SOBRE PROCEDIMENTOS: (marcar $n^{\circ}$ de vezes

realizadas)

FOI SOLICITADO PARA REALIZAR O RECOBRIMENTO DE

ALGUMA PINTURA? (marcar $n^{\circ}$ vezes)

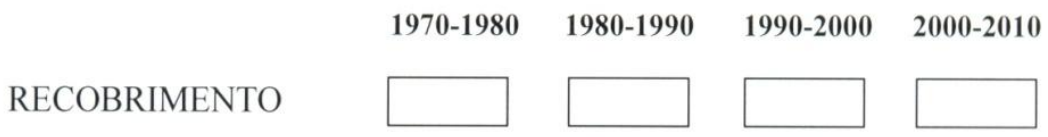

FOI SOLICITADO PARA REALIZAR A REMOÇÃO DE UM TIPO DE RECOBRIMENTO SOBRE UM A PINTURA? (marcar $n^{\circ}$ vezes)

$\begin{array}{llllll} & 1970-1980 & 1980-1990 & 1990-2000 & 2000-2010 \\ \text { REMOÇÃO } & & & \\ & & & \\ & & & \end{array}$

QUEM GERALMENTE ESTÁ ENVOLVIDO EM TOMAR ESTAS DECISÕES: (marcar $\mathrm{x}$ )

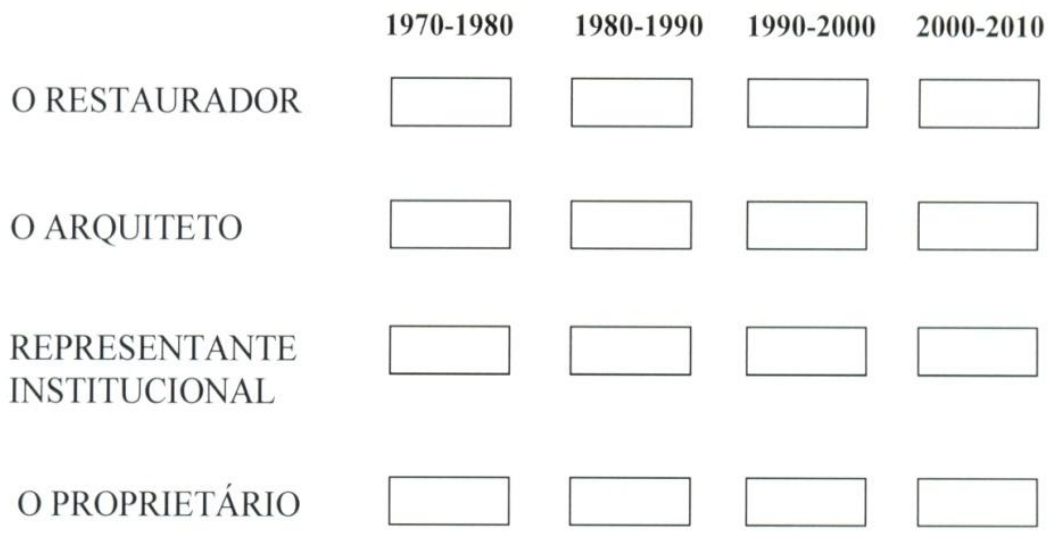

OUTROS: 


\section{ARTE MURAL}

FOI SOLICITADO PARA RESTAURAR UMA OBRA JÁ RESTAURADA (COM INTERVENÇÃO) ANTERIORMENTE? (marcar $\mathrm{n}^{\circ}$ obras)

$\begin{array}{lllll} & 1970-1980 & 1980-1990 & 1990-2000 & 2000-2010 \\ \text { QUANDO } & \square & \square & \square \\ & & & \\ & & \end{array}$

QUEM RESTAUROU A OBRA ANTES? QUANDO ? (marcar x)

$$
1970-1980 \quad 1980-1990 \quad 1990-2000 \quad 2000-2010
$$

O PRÓPRIO ARTISTA

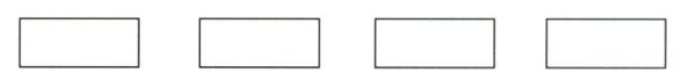

OUTRO ARTISTA
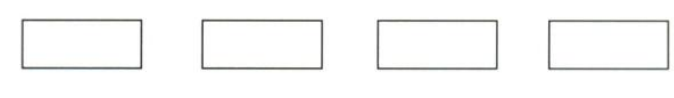

UM RESTAURADOR
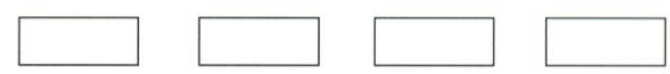

ALGUÉM INDICADO

PELO PROPRIETÁRIO
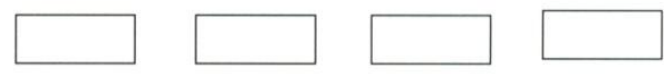

UM DESCONHECIDO
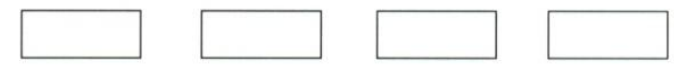

OUTROS: 
FOI SOLICITADO PARA REMOVER UMA OBRA MURAL DE UM LOCAL ORIGINAL PARA OUTRO? (marcar $n^{\circ}$ obras)

\begin{tabular}{lllll} 
& $1970-1980$ & $1980-1990$ & $1990-2000$ & $2000-2010$ \\
QUANDO & $\square$ & $\square$ & $\square$ \\
\hline
\end{tabular}

PARA ONDE FOI LEVADA A OBRA? (marcar $n^{\circ}$ de obras)

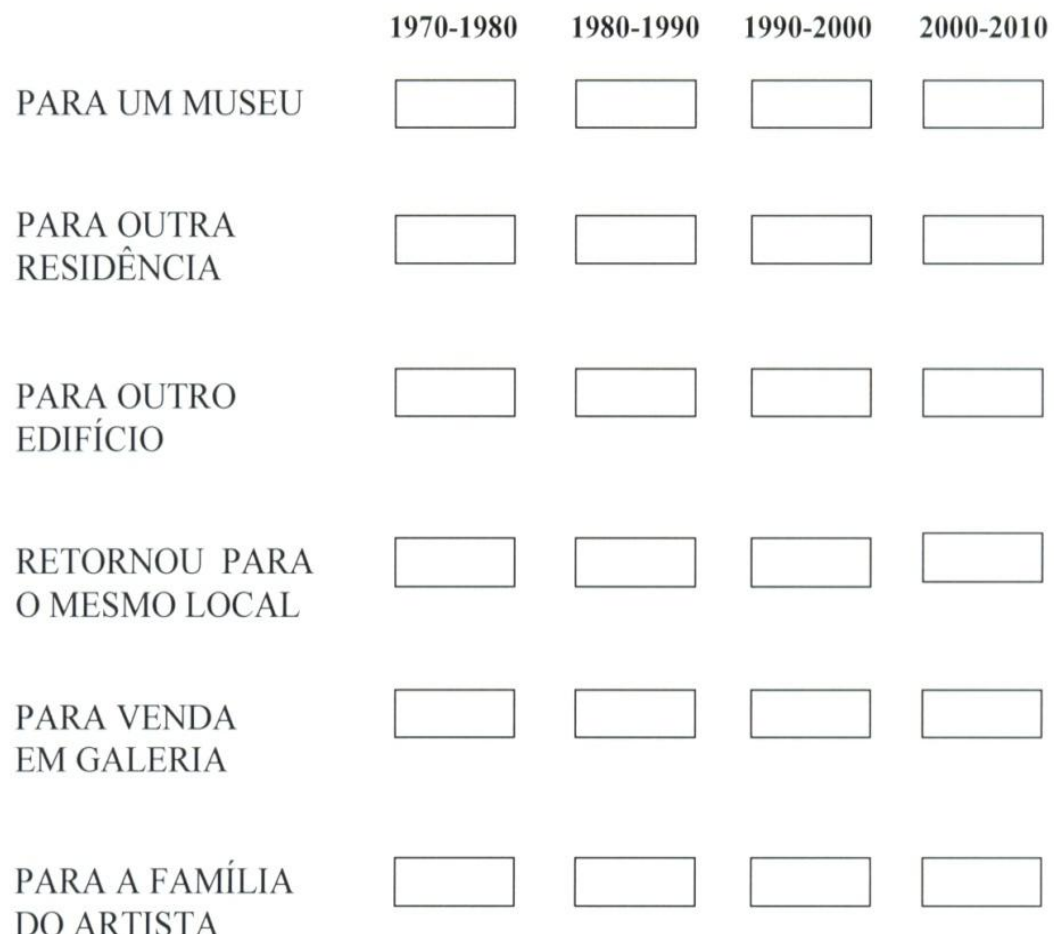
DO ARTISTA

OUTROS: 


\section{ARTE MURAL}

QUAL O TIPO DE OBRA MURAL COM QUE TRABALHOU?

(marcar $n^{\circ}$ obras)

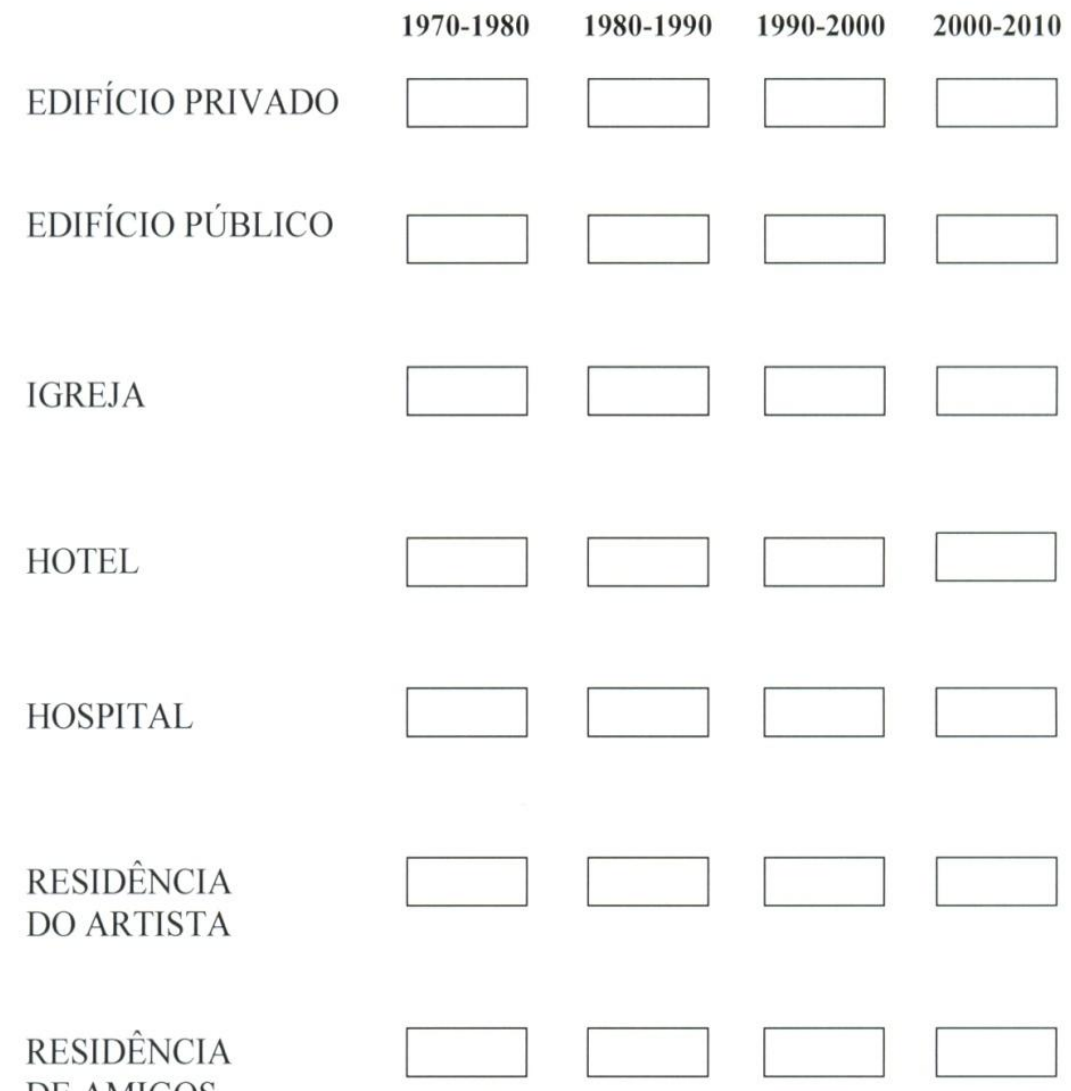

DE AMIGOS

DO ARTISTA

OUTROS: 
HOUVE MUDANÇAS SIGNIFICATIVAS NO USO DE MATERIAIS ESPECÍFICOS PARA A ÁREA? (marcar com $\mathrm{x}$ )

$\begin{array}{lllll} & 1970-1980 & 1980-1990 & 1990-2000 & 2000-2010 \\ \text { QUANDO } & \square & \square & \square \\ & & \end{array}$

HOUVE ALTERAÇÃO NAS EXIGÊNCIAS DA ATUAÇÃO DO PROFISSIONAL NA ÁREA POR PARTE DAS INSTITUIÇÕES OU MESMO DO MERCADO? (marcar com x)

SIM
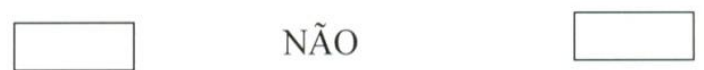

$1970-1980 \quad 1980-1990 \quad 1990-2000 \quad 2000-2010$

QUANDO

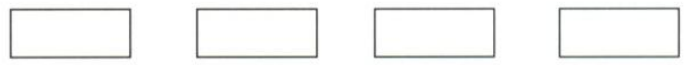

UTILIZA SERVIÇOS DAS ÁREAS DE CIÊNCIAS NATURAIS (QUÍMICA, FÍSICA, ETC) PARA SUPORTE TÉCNICO NA EXECUÇÃO E SUAS INTERVENÇÕES? (marcar com x)

SIM

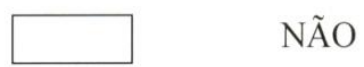

NÃO

TEM FÁCIL ACESSO A ESSES SERVIÇOS? DESDE QUANDO? (marcar com $\mathrm{x}$ )

SIM

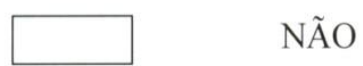

HOUVE OPORTUNIDADES DE RECICLAGEM E APERFEIÇOAMENTO NA ÁREA AQUI?

SIM
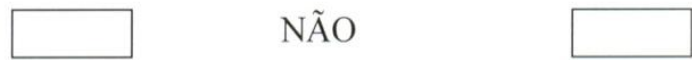

HOUVE MAIOR DIVULGAÇÃO DE TRABALHOS E DE INFORMAÇÕES TÉCNICAS SOBRE A ÁREA?

SIM

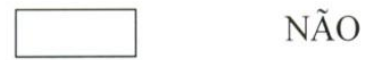

NÃO 


\section{Anexo II}

Princípios do ICOMOS para a Preservação e Conservação - Restauração das Pinturas Murais (2003) 
[PDF-151 Kb]

\section{ICOMOS PRINCIPLES FOR THE PRESERVATION AND}

CONSERVATION/RESTORATION OF WALL PAINTINGS(2003)

\section{Ratified by the ICOMOS 14th General Assembly, in Vicoria Falls, Zimbabwe, October 2003}

\section{Introduction and Definition}

Wall paintings have been cultural expressions of human creation throughout history, from the earliest beginnings, such as rock art, extending up to present day murals. Their deterioration, accidental or intentional destruction constitutes a loss affecting a significant part of the world's cultural heritage.

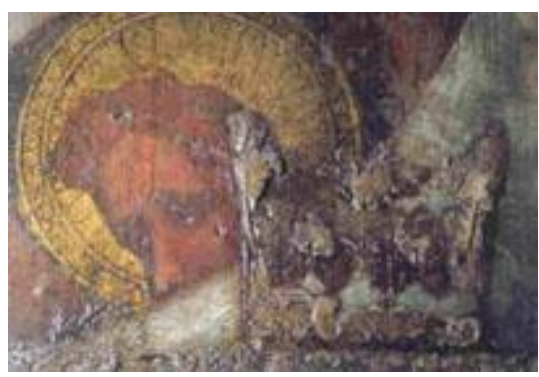

The Venice Charter (1964) has provided general principles for the conservationrestoration of cultural heritage. The Amsterdam Declaration (1975) introducing the concept of integrated conservation, and the Nara Document on Authenticity (1994) dealing with cultural diversity, have expanded these principles. Taking into account these and additional relevant contributions, such as the ICOM-CC Code of Ethics (1984), Document of Pavia (1997), and E.C.C.O. Professional Guidelines (1997), the aim of this document is to provide more specific principles for the protection, preservation and the conservation-restoration of wall paintings. This document, therefore, reflects basic and universally applicable principles and practices, and does not take into account particular problems of regions or countries, which can be supplemented at regional and national level by providing further recommendations where necessary.

The richness of wall paintings is founded on the variety of cultural expressions, aesthetic achievements, and the diversity of materials and techniques used from ancient until present times. The following articles refer to paintings created on inorganic supports, such as plaster, brick, clay and stone, and do not include paintings executed on organic supports, such as wood, paper and canvas. Composite materials in many historic buildings need special consideration outside the scope of this document. Architectural surfaces and their finishing layers, with their historical, aesthetic and technical values have to be considered as equally important components of historic monuments.

Wall paintings are an integral part of monuments and sites and should be preserved in situ. Many of the problems affecting wall paintings are linked to the poor condition of the building or structure, its improper use, lack of maintenance, frequent repairs and alterations. Also frequent restorations, unnecessary uncovering, and use of inappropriate methods and materials can result in irreparable damage. Substandard and inadequate practices and professional qualifications have led to unfortunate results. It is for this reason that an appropriate document covering the principles of proper conservationrestoration of wall paintings is necessary. 


\section{Article 1: Protection Policy}

A necessary approach to the protection of wall paintings of every culture and religion is to list and make inventories of monuments and sites including wall paintings, even in cases when they are not presently visible. Laws and regulations for the protection of cultural heritage must prohibit the destruction, the degradation or alteration of wall paintings, including their surroundings. Legislation should not only provide for the protection of wall paintings, but also make available resources for research, professional treatment and monitoring, and provide for the appreciation of their tangible and intangible values by society.

If interventions are required, these should be carried out with the full knowledge and the consent of the authorities responsible. Legal sanctions should be provided for any violation of such regulations. Legal provisions should also consider new discoveries and their preservation pending formal protection. Regional, urban or architectural development projects, such as the construction of roads, dams, conversion of buildings, etc. affecting wall paintings should not be carried out without an initial impact assessment study and without providing appropriate remedies for their safeguard.

Special efforts must be made through the co-operation of various authorities to accommodate and respect the cult function of religious paintings without compromising their authenticity.

\section{Article 2: Investigation}

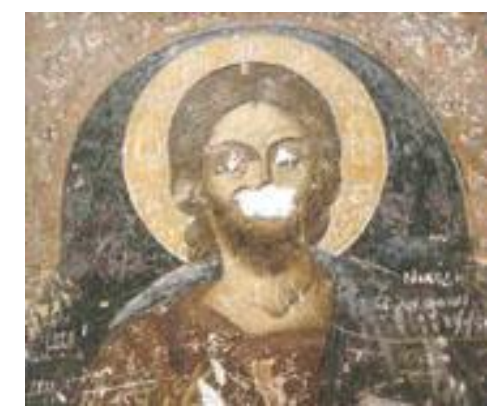

All conservation projects should begin with substantial scholarly investigations. The aim of such investigations is to find out as much as possible about the fabric of the structure and its superimposed layers with their historical, aesthetic and technical dimensions. This should encompass all material and incorporeal values of the painting, including historic alterations, additions and restorations. This calls for an interdisciplinary approach.

The methods of investigation should be as far as possible non-destructive. Special consideration should be given to wall paintings that may be hidden under whitewash, paint layers, plaster, etc. Prerequisites for any conservation program are the scientific investigation of decay mechanisms on macro and micro scale, the material analysis and the diagnosis of the condition.

\section{Article 3: Documentation}

In agreement with the Venice Charter, the conservation-restoration of wall paintings must be accompanied by a precise program of documentation in the form of an analytical and critical report, illustrated with drawings, copies, photographs, mapping, etc. The condition of the paintings, the technical and formal features pertaining to the process of the creation and the history of the object must be recorded. Furthermore, every stage of the conservation-restoration, materials and methodology used should be documented. This report should be placed in the archives of a public institution and made available to the interested public. Copies of such documentation should also be kept in situ, or in the possession of those responsible for the monument. It is also recommended that the results of the work should be published. This documentation 
should consider definable units of area in terms of such investigations, diagnosis and treatment. Traditional methods of written and graphic documentation can be supplemented by digital methods. However, regardless of the technique, the permanence of the records and the future availability of the documentation is of utmost importance.

\section{Article 4: Preventive Conservation, Maintenance and Site Management}

The aim of preventive conservation is to create favourable conditions minimising decay, and to avoid unnecessary remedial treatments, thus prolonging the life span of wall paintings. Appropriate monitoring and the control of the environment are both essential components of preventive conservation. Inappropriate climatic conditions and moisture problems can cause deterioration and biological attacks. Monitoring can detect initial processes of decay of the painting or the supporting structure, thus preventing further damage. Deformation and structural failure leading even to possible collapse of the supporting structure, can be recognised at an early stage. Regular maintenance of the building or the structure is the best guarantee for the safeguard of the wall paintings.

Inappropriate or uncontrolled public uses of monuments and sites with wall paintings can lead to their damage. This may necessitate the limitation of visitors and, in certain cases, involve temporary closure to public access. However, it is preferable that the public should have the opportunity to experience and appreciate wall paintings as being part of the common cultural heritage. It is, therefore, important to incorporate into the site management careful planning of access and use, preserving, as far as possible, the authentic tangible and intangible values of the monuments and sites.

Due to various sociological, ideological and economical reasons many wall paintings, often situated in isolated locations, become the victims of vandalism and theft. In these cases, the responsible authorities should take special preventive measures.

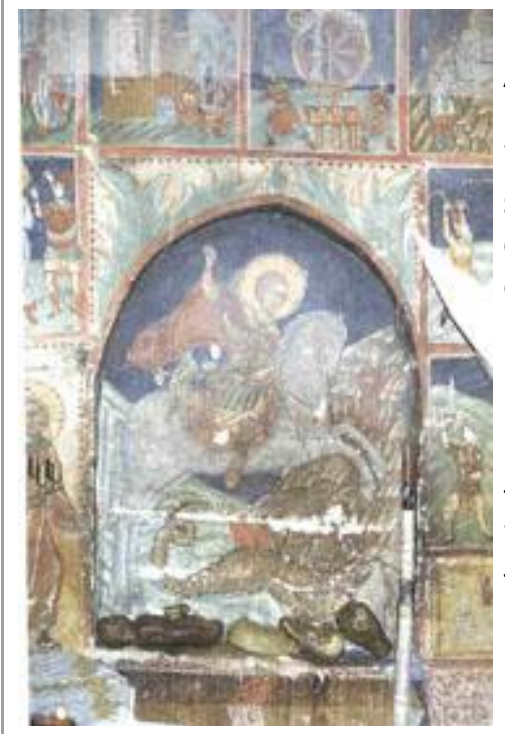

\section{Article 5: Conservation-Restoration Treatments}

Wall paintings are an integral part of the building or structure. Therefore, their conservation should be considered together with the fabric of the architectural entity and surroundings. Any intervention in the monument must take into account the specific characteristics of wall paintings and the terms of their preservation. All interventions, such as consolidation, cleaning and reintegration, should be kept at a necessary minimal level to avoid any reduction of material and pictorial authenticity. Whenever possible, samples of stratigraphic layers testifying to the history of the paintings should be preserved, preferably in situ.

Natural ageing is a testimony to the trace of time and should be respected. Irreversible chemical and physical transformations are to be preserved if their removal is harmful. Previous restorations, additions and over-painting are part of the history of the wall painting. These should be regarded as witnesses of past interpretations and evaluated critically.

All methods and materials used in conservation and restoration of wall paintings should take into account the possibility of future treatments. The use of new materials and methods must be based on comprehensive scientific data and positive results of testing in laboratories as well as on sites. However, it must be kept in mind that the long term effects of new materials and methods on wall paintings are unknown and could be 
harmful. Therefore, the use of traditional materials, if compatible with the components of the painting and the surrounding structure, should be encouraged.

The aim of restoration is to improve the legibility of form and content of the wall painting, while respecting the original creation and its history. Aesthetic reintegration contributes to minimising the visibility of damage and should primarily be carried out on non-original material. Retouching and reconstructions should be carried out in a way that is discernible from the original. All additions should be easily removable. Over-painting must be avoided.

Uncovering of wall paintings requires the respect of the historic situation and the evaluation of what might be lost. This operation should be executed only after preliminary investigations of their condition, extent and value, and when this is possible without incurring damage. The newly uncovered paintings should not be exposed to unfavourable conditions.

In some cases, reconstruction of decorative wall paintings or coloured architectural surfaces can be a part of a conservation-restoration program. This entails the conservation of the authentic fragments, and may necessitate their complete or partial covering with protective layers. A well-documented and professionally executed reconstruction using traditional materials and techniques can bear witness to the historic appearances of facades and interiors.

Competent direction of conservation-restoration projects should be maintained at all stages and have the approval of the relevant authorities. It would be desirable that independent supervision of the project were insured by competent authorities or institutions without commercial interest in the outcome. Those responsible for management decisions must be named, and the work must be implemented by professionals with appropriate knowledge and skills.

\section{Article 6: Emergency Measures}

In urgent cases, immediate emergency treatment is necessary for the safeguard of wall paintings. Materials and techniques employed must permit later treatment. Appropriate conservation measures must follow as soon as possible with the permission of the relevant authorities.

Detachment and transfer are dangerous, drastic and irreversible operations that severely affect the physical composition, material structure and aesthetic characteristics of wall paintings. These operations are, therefore, only justifiable in extreme cases when all options of in situ treatment are not viable. Should such situations occur, decisions involving detachment and transfer should always be taken by a team of professionals, rather than by the individual who is carrying out the conservation work. Detached paintings should be replaced in their original location whenever possible.

Special measures should be taken for the protection and maintenance of detached paintings, and for the prevention of their theft and dispersion.

The application of a covering layer concealing an existing decoration, carried out with the intention of preventing damage or destruction by exposure to an inhospitable environment, should be executed with materials compatible with the wall painting, and in a way that will permit future uncovering. 


\section{Article 7: Research and Public Information}

The establishment of research projects in the field of conservation-restoration of wall paintings is an essential requisite of sustainable preservation policy. Investigations based on research questions, which have potential to add to the knowledge of degradation processes should be encouraged. Research that will expand our knowledge of the original painting techniques, as well as materials and methods of past restoration practices are essential in the implementation of appropriate conservation projects. This research is also relevant to related disciplines of the arts and sciences. The disturbance of significant fabric for study, or to obtain samples, should be minimised.

Dissemination of knowledge is an important feature of research, and should be done on both the professional and popular levels. Public information can substantially advance awareness of the need for preservation of wall paintings, even if conservationrestoration work may cause temporary inconveniences.

\section{Article 8: Professional Qualifications and Training}

Conservation-restoration of wall paintings is a specialised discipline in the field of heritage preservation. As this work requires specific knowledge, skills, experience and responsibility, conservators-restorers of this kind of cultural property should be professionally educated and trained, as recommended by the Code of Ethics of the ICOM-Committee of Conservation (1984) and by associations such as E.C.C.O. (European Confederation of Conservator-Restorers Organisations) and ENCoRE (European Network for Conservation-Restoration Education).

\section{Article 9: Traditions of Renewal}

In many regions of the world, the authentic painting practices of artists and craftsmen are continued by repeating historic decorative and iconographic programs using traditional materials and techniques. These traditions, satisfying religio-cultural needs and keeping to the Nara principles, should be sustained. However, as important as it is to preserve this special knowledge, this does not imply that the conservation-restoration treatments of wall paintings are to be carried out by craftsmen or artists.

\section{Article 10: International Co-operation}

Sharing the care for common heritage is nationally and internationally an accepted concept. It is therefore necessary to encourage the exchange of knowledge and to disseminate information at every level. In the spirit of interdisciplinary collaboration, conservators-restorers of wall paintings need to liaise with their colleagues in other countries and with relevant institutions and specialists around the world.

This document, in its present form, was drafted in Copenhagen from 28th October 28 to 1 November 2002. It was edited and completed in Thessaloniki from 8 to 9 May 2003. Rapporteur: Isabelle Brajer.

\section{Participants}

R.C. Agrawal (India)

Valia Anapliotou (Greece)

Stefan Belishki (Bulgaria)

Giorgio Bonsanti (Italy) 


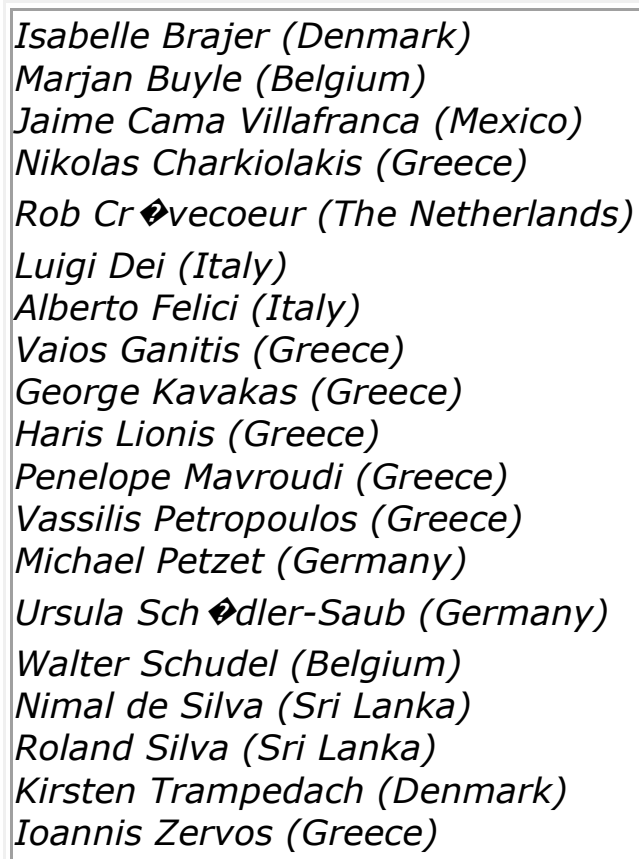




\section{Anexo III}

Código de Ética do Conservador-Restaurador (2005) 


\section{CÓDIGO DE ÉTICA}

\section{INTRODUÇÃO}

\section{CÓDIGO DE ÉTICA DO CONSERVADOR-RESTAURADOR}

\section{Relação com os bens culturais}

2. Pesquisa e documentação

3. Relação com proprietário ou responsável legal

4. Relação com o público

5. Relação com colegas e com a profissão

\section{INTRODUÇÃO}

Conservar e restaurar obras do patrimônio histórico, artístico e cultural é uma profissão que requer de quem a ela se dedica extensa cultura, treinamento e aptidões especiais.

Aos cuidados destes profissionais são entregues bens culturais que constituem herança material e cultural da sociedade. Por bens culturais entendemos aqueles objetos a que a sociedade atribui particular valor artístico, histórico, documental, estético, científico, espiritual ou religioso. A sociedade atribui ao conservador-restaurador o cuidado destes bens, o que exige grande senso de responsabilidade moral, além da responsabilidade em relação ao proprietário ou responsável legal, a seus colegas e a seus supervisores, à sua profissão, ao público e à posteridade.

Entendemos preservação de modo abrangente, compreendendo todas as ações que visam retardar a deterioração e possibilitar o pleno uso dos bens culturais.

Conservação-restauração seria o conjunto de práticas específicas, destinadas a estabilizar o bem cultural sob a forma física em que se encontra, ou, no máximo, recuperando os elementos que o tornem compreensível e utilizável, caso tenha deixado de sê-lo. Por conservação preventiva designamos o conjunto de ações nãointerventivas que visam prevenir e/ou retardar os danos sofridos, minimizando o processo de degradação dos bens culturais.

O papel fundamental do conservador-restaurador é a preservação dos bens culturais para benefício da atual geração e das gerações futuras. Para tal, este profissional realiza diagnóstico, tratamentos de conservação e restauração dos bens culturais, a respectiva documentação de todos os procedimentos, além do estabelecimento de atividades referentes à conservação preventiva.

É ainda da competência do conservador-restaurador:

Desenvolver programas de inspeção e ações de conservação e restauro.

> Emitir pareceres técnicos e dar assistência técnica para a conservação e restauro dos bens culturais.

> Realizar pesquisas sobre a conservação e restauro (materiais e métodos). 
$>$ Desenvolver programas educacionais, de treinamento, e lecionar conservação e restauro.

> Disseminar informação obtida através do diagnóstico, tratamento ou pesquisa.

> Promover conhecimento e maior entendimento sobre conservação e restauro.

O conservador-restaurador não é artista, nem artesão. É um profissional de nível superior, que pode ser oriundo das áreas de ciências humanas, exatas ou biológicas. $\mathrm{O}$ artista e $\mathrm{o}$ artesão criam, dominam as técnicas e podem conhecer bem os materiais, mas não possuem a formação, nem dispõem de conceitos fundamentais para a intervenção em bens culturais.

O presente código visa estabelecer normas e princípios que orientem o conservadorrestaurador na boa prática de sua profissão.

\section{CÓDIGO DE ÉTICA DO CONSERVADOR-RESTAURADOR}

\section{Relação com os bens culturais}

1. Toda a atuação do conservador-restaurador deve ser orientada pelo absoluto respeito ao valor e significado estético e histórico, bem como à integridade física dos bens culturais que lhe estejam afetos.

2. O conservador-restaurador deve contratar e empreender apenas os trabalhos que possa realizar com segurança, dentro dos limites de seus conhecimentos e dos equipamentos de que dispõe, a fim de não causar danos aos bens culturais, ao meio ambiente ou aos seres humanos.

3. Sempre que for necessário ou adequado, o conservador-restaurador deve consultar especialistas de qualquer uma das atividades que the complementem a atuação, envolvendo-os em ampla troca de informações.

4. Em qualquer situação de emergência onde um bem cultural esteja em perigo iminente, 0 conservador-restaurador deve dar toda a assistência possível, independentemente de sua área de especialização.

5. O conservador-restaurador deve levar em consideração todos os aspectos relativos à conservação-preventiva, antes de intervir em quaisquer bens culturais e sua iniciativa deverá restringir-se apenas ao tratamento necessário.

6. O conservador-restaurador, em colaboração com outros profissionais relacionados com a salvaguarda dos bens culturais, deve levar em consideração a utilização econômica e social dos bens culturais, enquanto salvaguarda desses mesmos bens. 
7. Em qualquer trabalho executado em um bem cultural o conservador-restaurador deve envidar esforços para atingir o máximo de qualidade de serviço, recomendando e executando aquilo que julgar ser o melhor no interesse do bem cultural, independente de sua opinião sobre o valor ou qualidade do mesmo e sempre de acordo com o princípio do respeito e da mínima intervenção possível.

8. É obrigação do conservador-restaurador realizar intervenções que permitam, no futuro, outras opções e/ou futuros tratamentos, não devendo a forma de utilização e os materiais aplicados interferir, sempre que possível, com futuros diagnósticos, tratamentos ou análises. Os materiais aplicados devem ser compatíveis com aqueles que constituem os bens culturais e devem ser evitados produtos e materiais que ponham em risco a integridade da obra.

9. O conservador-restaurador nunca deve remover materiais originais ou acrescidos dos bens culturais, a não ser que seja estritamente indispensável para a sua preservação, ou que eles interfiram em seu valor histórico ou estético. Neste caso será retirada uma amostra, que embora mínima, possibilite a identificação do problema. Para tal, será solicitado o consentimento do proprietário ou responsável legal. O material removido deve ser, se possível, conservado, como parte da documentação do bem cultural.

10. Na compensação de acidentes ou perdas, o restaurador não deve, eticamente, encobrir ou modificar o que existe do original, de modo a não alterar suas características e condições físicas após o evento.

11. É responsabilidade do conservador-restaurador manter-se atualizado frente ao progresso, as pesquisas e inovações desenvolvidas em seu campo de trabalho, bem como buscar constantemente o aprimoramento de seu discernimento, bom senso, habilidades e perícia.

12. Sendo responsável pela proteção, guarda e preservação do objeto que the foi confiado, o conservador-restaurador não deve contratar, ou admitir em sua equipe, pessoas insuficientemente treinadas, a não ser que possa estar permanentemente presente na constante supervisão dos trabalhos.

13. Nos casos em que a utilização ou exposição de um bem cultural seja prejudicial à sua preservação, o conservador-restaurador deve alertar o proprietário ou seu responsável legal dos riscos a que este está submetido. Havendo necessidade de reproduzir uma obra removida de seu local de origem, esta reprodução deverá ser feita por um especialista, evitando o uso de materiais e procedimentos nocivos à obra original.

\section{Pesquisa e Documentação}

14. Antes de iniciar qualquer ação ou intervenção em uma obra o conservadorrestaurador deve colher todas as informações capazes de gerar e salvaguardar o conhecimento a seu respeito, além de levar a cabo um acurado exame de sua composição e estado de conservação, recorrendo para isto, se necessário, as instituições e técnicos de outras áreas, nacionais ou internacionais. Os resultados desse exame devem ser extensamente anotados e documentados, 
fotograficamente, por meio de gráficos, mapas, tabelas e análises estatísticas. Baseado nestes dados, o restaurador elaborará um relatório sobre a peça e estabelecerá o procedimento a ser seguido, o qual deverá ser apresentado ao proprietário ou guardião legal do bem.

15. Durante o tratamento devem ser anotadas todas as intervenções de conservação-restauração, como produtos químicos (com a proporção ou percentagem de cada componente da mistura) e técnicas empregadas, seus efeitos e resultados, bem como quaisquer informações consideradas relevantes. A documentação fotográfica deverá acompanhar os passos mais expressivos do tratamento e registrar o efeito final da obra após o término do trabalho.

16. Esta documentação poderá ser apresentada em congressos ou publicada em periódicos técnicos. Deverá, ainda, ser fornecida sob a forma de relatório, ao proprietário ou responsável legal pelo bem cultural, aos curadores de museus e instituições. Entretanto, no caso de pessoas sem o devido conhecimento técnico, não é aconselhável o fornecimento da listagem de materiais químicos e detalhamento de sua utilização, a fim de evitar possíveis danos causados pelo uso inadequado.

17. Toda esta documentação comporá um dossiê, propriedade intelectual do conservador, que passará a ser parte integrante do bem cultural em questão.

\section{Relação com proprietário ou responsável legal}

18. O restaurador tem a liberdade de contratar seus serviços com particulares, instituições, órgãos governamentais etc, contanto que este contrato ou acordo não contrarie os princípios aqui definidos e tendo a liberdade de escolha do critério técnico e filosófico de restauro, que julgar mais adequado à obra.

19. O estabelecimento da remuneração por um trabalho a ser realizado deve ser justo, tendo em vista o respeito ao proprietário ou responsável legal e à profissão. Para estabelecer um preço é correto considerar:

$>$ tempo e mão de obra necessários

$>$ custo do material a ser empregado

$>$ despesas fixas

$>$ custos de análises científicas e pesquisas históricas

$>$ custo de seguro (se houver)

$>$ grau de dificuldade do tratamento a ser executado

$>$ riscos pessoais e insalubridade

$>$ problemas advindos do tratamento de objeto de excepcional valor

$>$ despesas com embalagem e/ou transporte

$>$ preço de mercado para trabalhos semelhantes

$>$ periodicidade do serviço: permanente ou esporádico.

20. A situação financeira do proprietário não justifica a elevação do preço em relação ao trabalho executado. 
21. O conservador-restaurador não deve supervalorizar nem desvalorizar seus serviços. A peculiaridade de cada caso impede o estabelecimento de tabelas de padronização de tarifas a serem cobradas.

22. Alterações no custo de um serviço contratado, bem como modificações no tratamento previsto, só podem ser feitas com o conhecimento e aquiescência do proprietário ou responsável legal.

23. O conservador-restaurador deve ter em mente que o proprietário ou responsável legal é livre para selecionar, sem influências ou pressões, o serviço do restaurador ou restauradores de sua confiança e com a mesma liberdade trocar de um para outro. Entretanto, uma vez o serviço contratado verbalmente ou por escrito, nenhuma das partes pode eticamente romper este contrato, a não ser de comum acordo.

24. Tendo em vista que raramente o proprietário tem suficiente conhecimento para julgar o que se faz necessário para a conservação da obra que possui, o conservador-restaurador deve com sinceridade e honestidade expor o tratamento que considera adequado ao caso. Pela mesma razão deve se negar a realizar ações que sejam requisitadas, mas que possam por em risco, desfigurar, ou comprometer a integridade e autenticidade da obra.

25. O conservador-restaurador deve informar o proprietário ou responsável legal sobre os meios adequados para a sua manutenção futura, incluindo questões referentes ao transporte, manuseio, armazenagem e exposição.

26. Uma vez solicitado a executar um trabalho, o conservador-restaurador deve estabelecer um prazo aproximado para término e devolução da obra, e fazer o possível para respeitá-lo.

27. Mesmo considerando que o conservador-restaurador empregue o máximo de seus conhecimentos e de sua habilidade para conseguir os melhores resultados no tratamento de uma obra, não seria excessivo o fornecimento de garantia pelo serviço realizado. Isto, entretanto, não impede que o mesmo se prontifique a corrigir alterações não previstas ou prematuras que possam ocorrer, desde que estejam observadas as recomendações de conservação mencionadas no "item n ${ }^{\circ} 25^{\prime}$ " deste documento, sem que para isto cobre remuneração extra.

28. O conservador-restaurador é obrigado a manter confidencialidade profissional. Sempre que queira fazer referência a um bem cultural deve obter o consentimento do proprietário ou legal responsável, salvo para fins didáticos ou científicos.

\section{Relação com o público}

29. O conservador-restaurador deve usar as oportunidades que se apresentarem para esclarecer o público sobre as práticas de preservação e as razões e meios da restauração. 
30. O conservador-restaurador, quando solicitado, deve prestar esclarecimentos e dar conselhos àqueles que forem vítimas de práticas negligentes ilegais ou antiéticas, salvaguardando a honorabilidade da profissão.

31. Fazer "expertise" ou autenticação remunerada não é considerada atividade apropriada ou ética para um conservador-restaurador, embora seu trabalho de exame e restauração de uma obra o tornem habilitado a contribuir para o conhecimento de sua história e autenticidade.

32. Propaganda feita através de jornais, revistas etc, não é condenável desde que não envolva comparação de habilidades ou preços com outros profissionais.

\section{Relação com colegas e com a profissão}

33. O conservador-restaurador deve manter um espírito de respeito aos colegas e à profissão.

34. O conservador-restaurador deve, dentro dos limites do seu conhecimento, competência, tempo e meios técnicos, participar da formação de estagiários e assistentes. Os direitos e objetivos do instrutor e do aprendiz devem ser claramente estabelecidos por ambos, que firmarão um acordo formal, do qual constarão itens como remuneração, duração do treinamento e áreas de abrangência do mesmo. Do certificado a ser emitido devem constar nome da instituição e do responsável pelo curso ou estágio, conteúdo do aprendizado e carga horária. O conservadorrestaurador é responsável pela supervisão do trabalho realizado pelos assistentes e estagiários, devendo responsabilizar-se igualmente pelo resultado deste trabalho.

35. O conservador-restaurador contribuirá, compartilhando suas experiências e conhecimentos, com os colegas de profissão. O criador de novos métodos de tratamento ou novos materiais prestará esclarecimentos sobre a composição e as propriedades de todos os materiais e técnicas empregadas, salvaguardados os direitos de patentes de propriedade do criador. Os registros relativos à conservação e restauração pelos quais o conservador-restaurador é responsável são a sua propriedade intelectual.

36. O conservador-restaurador não deve dar referências ou recomendação de uma pessoa candidata a um posto de profissional a não ser que esteja absolutamente seguro do treinamento, experiência e habilidade que a qualifiquem para tal.

37. Se no decorrer de um tratamento o restaurador se defrontar com problemas que Ihe suscitem dúvidas ou incertezas, este deve, sem hesitação e apoiado pelos preceitos da ética profissional, recorrer a outro colega que o auxilie na solução do problema.

38. É considerado anti-ético dar comissão a outro conservador ou qualquer outra pessoa pelo encaminhamento ou recomendação de um cliente. A divisão de remuneração só é aceitável quando existe a divisão de tarefas.

39. Nenhum membro de qualquer uma das associações profissionais da área pode emitir parecer ou falar em nome destas, a não ser quando para isto designado por 
votação efetuada em reunião da diretoria e/ou instâncias apropriadas de cada associação.

40. Caso surjam situações não mencionadas neste documento, o conservadorrestaurador deverá consultar-se com as associações representativas da categoria.

O presente texto foi elaborado a partir dos Códigos do International Council of Museums - ICOM, do American Institute of Conservation - AIC, do European Federation of Conservator-Restorers' Organizations - ECCO e de DUVIVIER, Edna May de A, Código de Ética: um enfoque preliminar, in: Boletim da Associação Brasileira de Conservadores-Restauradores de Bens Culturais ABRACOR, Ano VIII, N. 1 - Julho/1988, Rio de Janeiro, RJ, Brasil.

Participaram da elaboração e discussão para aprovação do texto final do Código de Ética acima exposto nos dias 27 de abril de 2005, 20 de junho de 2005, 16 de setembro de 2005 e 16 de novembro de 2005, os seguintes profissionais, conforme atas registradas:

Ana Maria do Prado: Arquiteta, Conservadora Restauradora de pintura de cavalete. Diretora Administrativa da APCR,

Antonio Luis Ramos Sarasá: Conservador Restaurador de patrimônio edificado,

Denise Magda Correa Thomasi: Conservadora Restauradora de acervos fotográficos.Presidente da ACCR,

Denise Zanini: Conservadora Restauradora de papel. Vice-presidente da ARCO IT.

José Dirson Argolo: Professor da cadeira de Restauração da Escola de Belas Artes da UFBA e diretor do Studio Argolo Antiguidades e Restaurações Ltda.

Lygia Maria Guimarães: Chefe do Núcleo de Conservação e Preservação de Acervos Arquivísticos e Bibliográficos - NUCON/COPEDOC/IPHAN, RJ. Presidente da ABRACOR,

Márcia de Mathias Rizzo: Conservadora Restauradora de pinturas. Diretora Técnica da empresa MRizzo, Laboratório de Conservação Restauração de Bens Culturais Ltda.

Maria de los Angeles Fanta: Conservadora Restauradora pintura de cavalete e papel. Presidente da APCR,

Naida Maria Vieira Correa: Conservadora Restauradora de pinturas e papel. Presidente da ACOR RS, Norma Cianflone Cassares: Conservadora Restauradora de papel. Presidente da ABER

Oriete Heloisa Cavagnari: Conservadora Restauradora de materiais pétreos, cerâmica arqueológica, escultório e arquitetura. Presidente da ARCO IT,

Regina Célia Martinez: Advogada, Mestre e Doutora em Direito, Consultora Jurídica e Professora Universitária,

Solange Zúñiga: Administração da Conservação. Doutora em Ciência da Informação pela UFRJ. Vicepresidente da ABRACOR

Stephan Schaefer: Conservador Restaurador, Cientista da Conservação, Professor Universitário do curso de Licenciatura em Conservação e Restauro da Universidade Nova de Lisboa, Portugal.

Tatiana Caliare: Conservadora Restauradora de madeira, pintura de cavalete e mural. Presidente da câmara técnica de ARCO IT.

Valéria Mendonça: Conservadora Restauradora. Chefe do Laboratório de Restauro da Pinacoteca do Estado de SP. 